


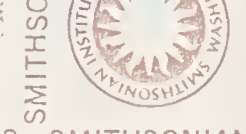

$\frac{1}{2}$
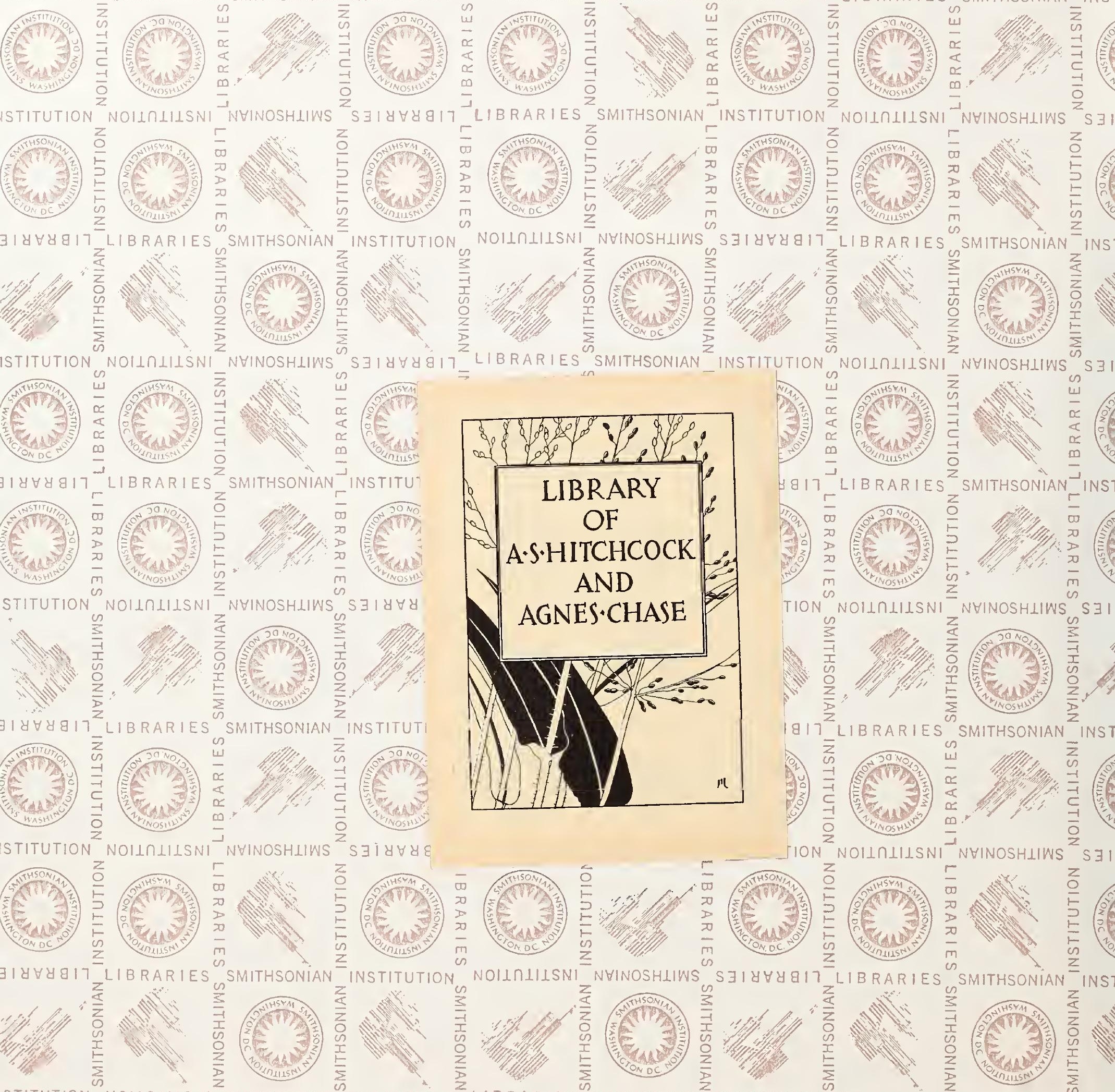





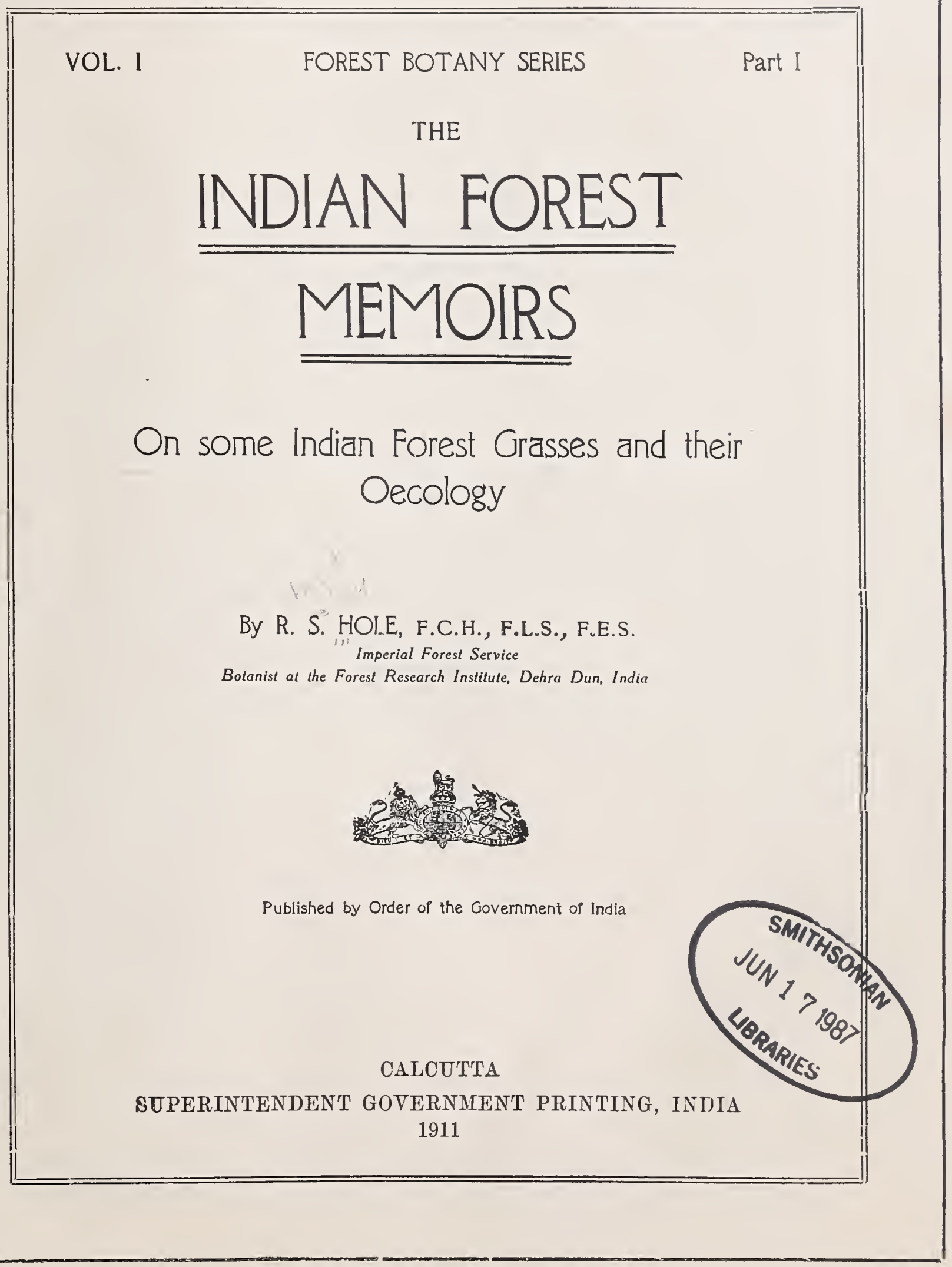





\section{CONTENTS.}

\section{INTRODUCTION.}

Importance of Forest Grasslands - Qicology defined-Hydrophytes,

PAGES.

Xerophytes, Mesophytes - Formation - Steppe - Sarannah - Association - Hygrophytes - Tropophytes - Primary subdivision into Grassland and Woodland advisable-Progressive, Regressive and Parallel Succession-Water supply not necessarily the dominant factor regulating the distribution of plant-communities-Adaptations to Temperature-Importance of Light--Plants with different adaptations in same Habitat-Suggested scheme of CEcological Classification for India-Value of CEcology for Forest Officers-Importance of Ecology in study of Plant Diseases-Utility of Forest ExperimentsImportance of Field Observations-Lines of work adopted in study of Forest Grasslands-Species selected-Arrangement of Information

$1-3 S$

CHAPTER I.

Description of Localiti.

Topography-Climate-Local Types of Vegetation . . . . . 39-49

\section{CHAP'TER II.}

(i) Detalled Description of Species.

Saccharum spontaneum . . . . . . . . . . 50-62

Saccharum Munja . . . . . . . . . . . . 62-79

Saccharum Narenga . . . . . . . . . . . . $79-87$

Erianthus Ravennæ . . . . . . . . . . . . $87-91$

Imperata arundinacea . . . . . . . . . . 91-102

Triraphis madagascariensis . . . . . . . . 102-105

Aristida cyanantha . . . . . . . . . . . 105-108

Andropogon monticola . . . . . . . . . 108-114

(ii) Summary of Chiff Characteristics of Species dealt with . . 115-117

\section{CHAPTER III.}

Suggestions regarding Practical Treatument of Local Grasslands.

Treatment with a view to Fodder-Production-Treatment with a view to

Afiorestation . . . . . . . . . . . 118-126 


\section{LIST OF PIATES.}

Plate I.-Map of Locality.

II.-Aristida cyanantha in typical habitats.

III.-Saccharum Munja and Saccharum spontaneum var. nepalense in their typical habitats.

IV.-Triraphis madagascariensis in typical habitat.

V.-Acacia Catcchu and Dry Miscellaneous Forest in their typical habitats.

VI.

VII.

VIII. - Erianthus Ravennce in typical habitate.

IX. I

X.j

XI. $\}$-Saccharum Narenga in typical habitats.

XIII.-Loam-form of Saccharum spontaneum in typical habitat.

X.IV.-Sand-form of Saccharum spontaneum.

XV.-Loam-form of Sacchamum spontaneum and var. nepalense.

IVI. )

XVII. Y Saccharum spontaneum.

XVIII.

XIX.j

XX.\}-Saccharum Munja.

XXI.)

XXII.-Saccharum arundinaceum.

XXIII. )

XXIV. $\}-S a c h a r u m$ Narenga.

$\mathrm{XXV}$.

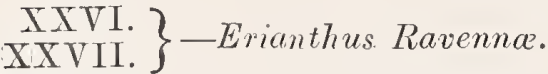

XXVIII.

XXIX. $\}$ - Imperata amindinacea.

XXY.

TXXI.

XXXII. $\}$-Triraphis madagascariensis.

XXXIII.)

XXXIV. ?

XXXV. $\}$-Aristida cyanantha.

XIXVI.

XXXVIT.

XXXVIII. $\}-A$ Adropogon monticola.

XXYIX.

X.L.--Gola Tappar, a local Grassland. 


\title{
THE INDIAN FOREST MEMOIRS
}

FOL. I]
[PARTI

\section{Some Indian Forest Grasses and their Oecology.}

\author{
By R. S. HOLE, F.C.H., F.L.S., F.E.S., \\ Imperial Forest Service \\ Botanist at the Forest Research Institute, Dehra Dun, India.
}

\section{INTRODUCTION.}

1. Indian Forest Grasses are of considerable Importance importance on account of the value of the economic products yielded by particular species. of 'orest Thus a considerable revenue is realised from the sale of such species as the Bhabar grass (Ischomum angustifolium, a valuable paper material), Rusa Oil Grass (Cymbopogon Martini, the source of the valuable Palmarosa or Rusa perfumery oil), Munj (Saccharum, Munja which yields a valuable textile fibre ard also a paper material) and others. This revenue will undoubtedly increase in the future as new industries arise and as the economic value of the various species becomes better and more widely known.

On the whole, however, there is no doubt that the primary importance of our forest grasslands depends on two facts :

(a) Their great value as grazing grounds and fodder yielding areas.

(b) The fact that where grass is of comparatively little value, these grasslands occupy large areas which might produce valuable forest and which it is therefore desirable to afforest.

2. As regards the value of our grasslands to value for the people of India for grazing purposes the following figures will indicate their enormous Folder and importance. These figures show the average forest area in India and Burma which has been annually open for grazing and the average annual number of buffaloes, cows, bullocks, 
goats and sheep which have been actually grazed in this area during the four years period 1904-08:-

\begin{tabular}{|c|c|c|c|c|}
\hline \multirow{2}{*}{$\begin{array}{c}\text { Area open to Grazing annually in } \\
\text { Fquare Miles. }\end{array}$} & \multicolumn{4}{|c|}{ Number of aximals Grazed ayndally. } \\
\hline & Buffaloes. & $\begin{array}{l}\text { Cows and } \\
\text { Bullocks. }\end{array}$ & $\begin{array}{l}\text { Goats and } \\
\text { Sheep. }\end{array}$ & Total. \\
\hline $197,: 25$ & $1,597,949$ & $7,683,682$ & $4,489,476$ & $13,771,107$ \\
\hline
\end{tabular}

In many parts of India, with the increase in tle numbers and in the prosperity of the local population of recent years, the number of cattle for which grazing is required in the Government Forests has steadily risen and the question of what measures are to be taken in order to satisfy as far as possible the urgent needs of the people with regard to fodder and grazing, without thereby unduly decreasing the area required for the satisfaction of the wants of the country in respect of wood, fuel and other forest products, for the protection of the headwaters of streams and for improving the water supply required for cultivated tracts, is now one of great difficulty and of pressing importance.

In whatever way a solution of this question of securing a satisfactory allotment of forest areas for these antagonistic interests is ultimately arrived at, it appears certain that large areas of the greatest value as grazing grounds, or as areas productive of good fodder grass, to meet present needs, or to serve as a reserve in times of famine, will always be situated within the boundaries of the Government Forests and such areas will consequently remain under the management of the Forest Department. It is also clear that with regard to such areas the forest estate will not adequately fulfil its task of satisfying, to the full extent of its possibilities, the needs of the people in respect of the produce which it is capable of yielding, until these grasslands are managed in such a way as to make them most productive of the best class of article required from them, i.e. until they are made to yield the maximum quantity of the best fodder grass which they are capable of producing.

3. On the other hand, large areas of grassland exist in forests almost throughout India which are not needed primarily for the production of fodder and which have been for many years carefully protected from fires and grazing in the hope that they would soon become naturally reafforested, with, in many cases, so far as can be seen, little or no practical result. Many of our forest grasslands also are annually burnt under proper control in order to diminish the danger of fire damage to the surrounding forest which would result from the accidental firing of the masses of dry inflammable grass contained in these areas in the dry season. Little is known at present regarding the effect, injurious or otherwise, of these annually repeated fires on the production of fodder, or on the capacity of the soil to produce good forest growth. The great importance of initiating an inquiry into the best method of treatment to apply to 
our forest grasslands $(a)$ with the object of improving the yicld of fodder and $(b)$ with the object of hastening their afforestation having been recognised, the Forest Botanist was directed in October 1908 to make a beginning with this work by studying the Savannahgrasses of the Sal (Shorea robusta) forests in Northern India. The present paper includes the results of the work which it has been found possible to carry out since that date, in the intervals of heavy educational and other duties in connection with the organisation of the Botany branch of the Imperial Forest Research Institute at Dehra Dun.

4. In order to obtain useful information Ecologieal regarding the best method of treatment to be applied to grasslands with the object of Forest improving the fodder yield on the one hand, and of favouring their natural afforestation (irasses with valuable forest trees on the other, an oecological study of the various grasses and woody species concerned is necessitated.

5. As the importance of CEcology is often Ecology insufficiently appreciated it appears desirable to explain, somewhat in detail, what is implied by this term. Ecology has been defined as "the science treating of the reciprocal

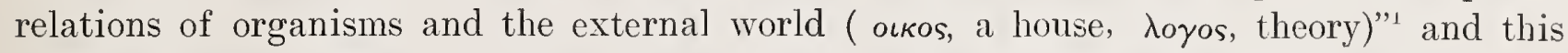
has been further elaborated by one of the highest oecological authorities as follows :-

"It teaches us how plants or plant-communities adjust their forms and modes of behaviour to actually operating factors, such as the amounts of available water, heat, light, nutriment, and so forth.

A casual glance shows that species by no means dispose their individuals uniformly over the whole area in which they occur, but group them into communities of very varied physiognomy. Ecology seeks-

(1) To find out which species are commonly associated together upon similar habitats (stations). This easy task merely involves the determination or description of a series of facts.

(2) To sketch the physiognomy of the vegetation and the landscape. 'This is not a difficult operation.

(3) To answer the questions-

Why each species has its own special habit and habitat, Why the species congregate to form definite communities, Why these have a characteristic physiognomy.

This is a far more difficult matter and leads us-

(4) To investigate the problems concerning the economy of plants, the demands that they make on their environment, and the means that they employ to utilise the surrounding conditions and to adapt their external and internal structure and general form for that purpose."2

Having therefore obtained a full knowledge of the ocology of a particular species, such as the Sal tree, and being able to fully explain why the species thrives under certain condi.

\footnotetext{
${ }_{1}$ Ecology of Plants. By E. Warming, Eng. Edn., 1909, p, 1.

${ }^{2}$ Warming, l.c., p. 2.
} 
tions and why it cannot exist under others, we shall be able to answer such questions as whether or not the species can thrive in localities where it does not at present exist, and if so what are the steps to be taken to make its successful introduction possible; also why the growth or reproduction of the species is unsatisfactory in a particular locality and what steps can be taken to counteract its diseases. In other words we shall know what treatment must be adopted in our Sal forests in order to secure their most satisfactory development and reproduction and what steps must be taken to extend the area of such forests by introducing the species where it does not at present exist.

While recognising therefore the vital importance of this study the magnitude and difficulty of the work must be apparent to the most casual observer; involving as it does a detailed knowledge of all the living and non-living factors of a plant's environment, of the way in which, and of the extent to which, each such factor is capable of influencing favourably or unfavourably the growth and development of that plant and of the extent to which the favourable or unfavourable effect of these factors may be increased or diminished by other factors.

These points may be illustrated by a few simple cases : a plant A, for instance, is under ordinary conditions of its liabitat able to kill out a plant B by its competitive action and this explains the absence of plant B in certain localities. In precisely similar habitats, however, which are periodically fired, plant $\mathrm{B}$ is found to thrive and $\mathrm{A}$ to be absent, or comparatively rare, and this is explained by the fact that plant $\mathrm{A}$ is more directly injured by fire than $B$, or that fire has caused a change in soil and moisture supply more unfavourable to $\mathrm{A}$ than $\mathrm{B}$. Firing, in consequence, is a simple treatment to adopt in order to favour the development of B in such localities where A occurs. Again, species B may be unable to exist on sandy soils owing to the small capacity of such soils for retaining moisture. This capacity is greatly increased by an admixture of humus and the introduction of a species A capable of thriving on dry sandy soil and of producing large quantities of humus may be the best step to be taken with a view to the ultimate introduction of species $B$.

In another case a species A may be unable to exist in clay soil owing to the supply of oxygen being insufficient for the healthy action of its roots. Species B which is able to thrive on clay soils and is less sensitive as regards the supply of oxygen may be capable of improving such soils by the drying action of its roots and by the formation of humus, ${ }^{1}$ and hence the introduction of species B may be the best procedure to adopt with a view to the ultimate establishment of species A. Again the available nitrogen in a forest soil depends largely on the rapid decomposition of the humus by bacteria and any factor which retards the growth and development of these bacteria may result in so impoverishing the upper layers of soil in respect of nitrogen that the seedlings of a particular species may be unable to grow in them and the reproduction of that species thus becomes impossible.

The production of good seed and vigorous seedlings also in many cases depends on the existence of the birds and insects by which the cross-pollination of the flowers is effected

1 "Humus acts as a weak cement and holds together the particles of soil, thus it serves both to bind a coarse-grained sundy soil, and, by forming aggregates of the finest particles, to render the texture of a clay soil more open." The Soil by A. D. Hall, 1908 , p. 47. 
and hence the factors which influence the healthy development and reproduction of such insects and birds may determine the area within which a particular plant is able to exist.

Finally the absence of a plant in localitics suitable for its devclopment may be accounted for by the simple fact that its seeds have not yet been able to reach thosc localities.

The importance of the direct injury inflicted by parasitic plants, such as fungi, by injurious insects, or by browsing animals such as goats, in rendering the cxistence of a particular plant in a certain locality impossible, is more obvious and needs no emphasizing and these remarks will make it clear that the complete wecological study of a particular species really comprises a complete knowledge of its physiology and pathology.

6. The fact that, to a certain extent, a know- Importance ledge of the physiology of a plant can be obtained by a study of its morphology and anatomy of logical and is of great importance in ocology. Thus the morphological characters of the fruit may cuatomical indicate the agency by which the seeds are distributed, such as wind, water, animals, and iu Eeology. so on; similarly the charactcrs of the flower may indicate the agency by which pollination is effected, such as wind or insects, while the morphological and anatomical characters of the leaf and the habit of the plant may indicate whether it is adapted to cxist in a sunny or shady, dry or wet locality.

By continually tracing the conncction existing in different localities between such characters of the vegetation and the factors of the cnvironment, a mere inspection of the regetation existing in localities, not hitherto visited, eventually sufficcs to give a fairiy accurate idea of the chief factors influencing plant growth which exist there and thus enables us to decide whether or not a certain species will be likcly to thrive there. The accuracy of such conclusions is greatly increased by a study of so-called indicator-plants. If a species $A$, for instance, is invariably found on soil which is known to be suitable for the vigorous development of species $B$, it is clear that we may regard the existence of $A$ as a direct indication of a locality suitable for $\mathrm{B}$, at all events so far as the characters of the soil are concerned.

Grasses are particularly valuable in this respect and a careful study of the grasses in forest blanks, in many cases, indicates to the Forester whether or not the conditions of soil and moisture are such as to render possible the afforestation of such blanks with a particular species, and similarly the existence of other grasses may indicate that the soil has become unsuitablc for a certain species and may thus explain why reproduction can no longer be obtained in those forests.

7. As the morphological and anatomical $\underset{\text { Schemes of }}{\text { Exing }}$ charactcrs of the vegetative organs, as well as the habit of plants generally, show the most Eeomesical ncticeable and striking variations in response to differences in the quantity of moisture tion. available for growth, occologists up to date have, as a rule, concentrated their attention primarily on this factor and have made it the basis of their œecological classifications.

Thus Professor Warming notes: "Water is the condition of life that exercises the greatest influence in bringing into being external and internal differences among plants; 
it is likewise water that plays the leading part in determining the creation of plant communities and their distribution over the soil." ${ }^{\prime \prime}$ He accordingly classifies plants into-

Hydrophytes, Xeropliytes, Mesophytes.
1.-Water- or Aquatic-

Plants = IIydrophytes
"Plants that pass the whole or the greater part of their lives sul- merged in the water, which envelops them completely or, at most, leaves definite floating parts of them un- covered at its sur- face."

II.-Land or Terrestrial-

Plants . . Those " that expose at least their assimilating organs to the air and hence to transpiration."' Those are subdivided into-.

(a) Jerophytes._-"Those species that are adapted to meet the conditions of strongest transpiration and most precarious water supply."

(b) Mesophytes.- "The re-

It is, however, pointed out that there is no sharp boundary between these groups " for there is a group of plants, marsh-plants (helophytes), which, like water-plants, develop their lower parts (roots, rhizomes, and, to some extent, leaves) in water or at least in soaking soil, but have their assimilatory organs mainly adapted to existence in air, as is the case with land-plants to which they are closely allied,"5 while "between these two classes (xerophytes and mesophytes) there is of course no strict boundary." " It should be noted that while Warming includes marsh plants in terrestrial plants, ${ }^{7}$ Clements classes them as hydrcphytes. ${ }^{s}$ For the present these plants may conveniently be considered as Hydrophytes.

Some idea of the kind of plants included in the above groups will be obtained from the following enumeration of a few of the more obvious characteristics of some typical plants :-

\section{Hydrophytes including Marsh plants.}

Roots are usually reduced. Root-hairs often absent. Owing to the buoyancy of water there is comparatively little need of strengthening mechanical tissue and submerged plants include no woody species. Owing to the slow diffusion of oxygen in water, all submerged parts of plants are especially liable to the dangers of an insufficient oxygen-supply for respiration and in consequence large and abundant air spaces in such parts are very characteristic and serve for the storage of oxygen and for the conduction of this gas from parts in the air to those in the water or saturated soil. The presence of these air spaces can often be detected by the naked eye.

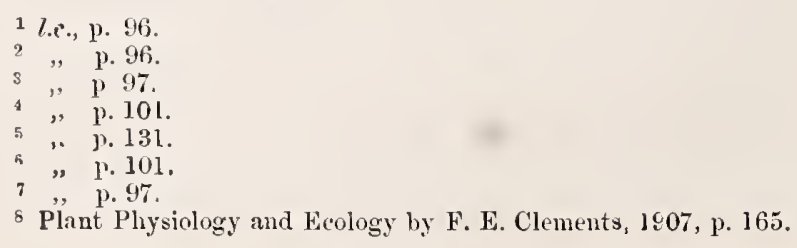


The supply of oxygen can also be augmented by increasing the absorbing surface of the plant which is in contact with the water and hence submerged leaves and, in some algæ, the entire plant are often cut into a number of long narrow segments.

Oxygen being usually more plentiful in running than in stagnant water, plants in rumning water tend to show comparatively less development of aerating devices.

The presence of aerating tissue is also of utility in increasing the buoyancy of the plant.

In woody marsh plants the so-called pneumatophores, or aerating roots, are often developed as an adaptation to meet the danger of a deficient oxygen-supply.

To some extent also the characteristics of the plants of this group are due to the weakening of the light in water and submerged parts of stems and leaves tend to become long and thin resembling those of terrestrial plants developed in shade.

The epidermis, especially of submerged parts, as a rule exhibits no devices for reducing transpiration such as a thick cuticle, covering of hair, wax, etc., and hydrophytes, when entirely removed from water, usually dry and wither with great rapidity.

As examples of this class of plants we may take aquatic Algæ or " sea-iveeds."

Trapa bispinosa, the water Chestnut, with its remarkably branched submerged leaves with filiform segments.

Nelumbium speciosum, the Sacred Lotus, with the enormous air spaces in its sub-. merged creeping stem.

\section{Xerophytes.}

The root system is usually strongly developed. Adaptations for reducing transpiration are very common and characteristic and amongst the most usual devices resorted to are-

(1) A reduction in the surface of those memhers which are, as a rule, most specialised with the object of facilitating transpiration, viz. the leaves. Thus some xerophytes are characterised by the relatively small size of their leaves and leaflets and others dispense more or less completely with leaves and place their chlorophyll tissue in their stems or branches.

(2) Development of a thick protective cuticle and often also of thick walled sclerenchymatous tissue beneath the epidermis which interfere with the free exchange of gases between the outer air and the moist thin-walled chlorophyll tissue beneath them. Coatings of wax and hairs serve the same purpose. The latter can dis a rule be easily recognised by eye and the former anatomical characters are frequently indicated in the field by the firm hard texture and also by the colour of the foliage, the colour of those leaves in which the chlorophyll is protected by thick-walled external cells usually being like that of leaves which are covered with a thin coating of wax, viz. a dull, or bluishgreen, as contrasted with a fresh bright green.

$$
\left[\begin{array}{ll}
7 & \text { ] }
\end{array}\right.
$$


As the stomata are the openings through which gaseous exchange chiefly takes place the protective coverings, e.g. of hairs, tend to occur chiefly on the under-surface, where the stomata in land plants mainly occur.

(3) As cork forms an excellent protection against free gaseous exchange a thick corky bark is often characteristic of woody plants, the water current ascending in the wood thus being protected.

(4) The loss of water by transpiration from a leaf depends greatly on the angle at which the leaf surface is exposed to the sun's rays, the loss, other things equal, being greatest when the leaf surface is perpendicular to the direction of the sun's rays and least when the surface is parallel to this direction, e.g. when the leaf exposes its edges only to the direct rays of the sun.

Thus motile leaves and leaflets are exceedingly common and characteristic and in many species can be recognised at once by the presence of the so-called pulvinus, pulvinule and glands.

(5) The presence of ethcreal oils and latex is believed to reduce transpiration, but in what way is not at present clearly understood.

(6) Water-storing tissue is often characteristic. Plants obtain their water when they can get it, even when it is not needed for immediate requirements, and then store it in these reservoirs where it is available for use when wanted. The presence of such tissue also diminishes transpiration by checking gaseous exchange and the conduction of heat.

The presence of such tissue is often indicated by a succulent, or soft, and somewhat spongy, texture and by the cxudation of water when fresh tissues are cut.

The above will suffice to indicate a number of familiar plants to Indian Foresters which, according to prevailing ocological ideas, must from their morphological and anatomical characters be considered as fairly typical xerophytes, e.g. the desert Prosopis spicigera with its extraordinarily deep-going root system; the practically leafless species of Tamarix, Casuarina, Euphorbia, Opuntia, Ephedra and Orthanthera; Calotropis with its glaucous green leaves woolly beneath, Pinus with bluish, or dull grcen, foliage, the texture of which is firm and hard and which is characterised by a well-developed cuticle and superficial sclerenchyma: Moringa and Erythrina with thick corky bark; Acacias with motile leaflets; Euphorbia and Calotropis with milky juice, and many dry locality Ruitaceo with ethereal ails, e.g. Feronia and Egle.

\section{Mesophytes.}

Warming notes that these plants " grow on soil which is of an intermediate character, and is neither specially acid, nor saline, but is moderately moist, usually well ventilated, also rich in nutriment and in alkaline humus or in other organic constituents. Mesophytic communities occur in very diverse climates, near the Poles or on the equator, yet. 
they can never be exposed to the danger of prolonged drought. Adapted to such conditions are plants that show a relatively weak development of the above-mentioned arrangements for regulating transpiration : in this respect these plants stand midway between hydrophytes and xerophytes. The leaves are large, and far more varied in form than in xerophytes; teeth and other incisions of the margin are common, as are compound or richly divided leaves; hydathodes seem to be frequent; the vegetative organs are of a fresh green, and devoid of thick grey coatings of hair or bluish incrustations of wax; the leaves are usually dorsiventral in structure. Stomata are numerous, often occurring also on the upper face of the leaf; anatomical peculiarities, such as aqueous tissues, are very rare, or at least not extremely developed."

Among the most typical forest trees of this group is the European Beech and the Indian tree which is probably most nearly allied ocologically is the Sal.

The anatomical and morphological characters of typical xerophytes may be described by the adjective xerophytic and the same term may be used for a locality where xerophytes grow, or for a plant group consisting of xerophytes.

The adjective xerophilous (=living in, or suited to, a dry habitat) derived from the corresponding substantive xerophile, is also frequently used. Similarly we have the terms hydrophilous and hydrophytic, mesophilous and mesophytic.

8. The most important natural plant group, The Formaor aggregate of individuals, at present recognised in œcological botany is the formation ${ }^{\text {tion. }}$ which may be considered as corresponding to the genus of systematic botany. Warming defines the formation " as a community of species, all belonging to definite growth-forms, ${ }^{2}$ which have become associated together by definite external (edaphic or climatic) characters of the habitat to which they are adapted. Consequently, so long as the external conditions remain the same, or nearly so, a formation appears with a certain determined uniformity and physiognomy, even in different parts of the world, and even when the constituent species are very different and possibly belong to different genera or families.

Therefore-

A formation is an expression of certain defined conditions of life, and is not con-

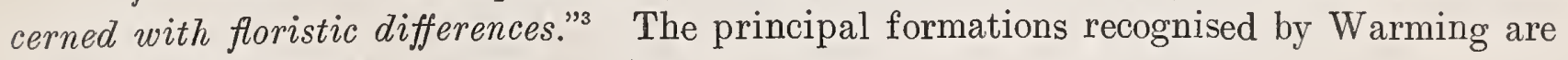
the following which he classifies as shown :-

Hydrophilous.-Formations in marsh and water (Hydrophytes and Helophytes).

Xerophilous.-Formations on sour (acid), cold and saline soil, formations on rock, sand, gravel and waste land, bush or scrub formations and formations on desert, steppe and savannah.

\footnotetext{
1 l.c., p. 135. vegetative activity, of flowering and fruiting, the duration of its life cycle, by the form and nature of its flowers, fruits, stems, lcaves and roots, in so far as such differcnces can be ascribed to the influence of the conditions of the plant's environment.

l.c., p. 140. 
Mesophilous.--Good examples of such formations are "meadows" and beech, oak and birch forest of temperate climates. Warming also includes in this group the deciduous (=monsoon forest) and evergreen forests of India but a more detailed knowledge of these formations would probably modify this arrangement.

The Indian Forester will at once recognise the very close relationship existing between desert and the formations of such trees as Sterculia urens and Bosuellia serrata which nevertheless come under the head of deciduous forests, while on the other hand some species of the evergreen forests such as Carallia integerrima, Cyclostemon assamicus and Calamus tenuis occur in swamps in the deciduous sal forests, and thus form a connecting link between the mesophilous and hydrophilous formations.

Such terms as marsh, desert and scrub need no definition but the terms steppe and savannah are of value in the description of our Indian forest grasslands and they have been defined as follows :-

Steppe.-Is a "Treeless plain clothed with grasses and other perennial herbs."* *

"The vegetation is xerophilous in character, and does not form a dense, close carpet. Both these features serve to distinguish grass-steppe from the allied formation, meadow, whose close vegetation consists of fresh-green, soft-leaved, and broad-leaved grasses and other perennial herbs. On the other hand, vegetation clothing grass-steppe is closer and taller than that of desert."

The importance of steppes to the Forester lies largely in the fact that they are usually considered to be an indication of conditions unsuitable for tree arowth which is naturally of great importance as regards the question of afforestation.

Savannah.-Schimper defines this as "xerophilous grassland containing isolated trees,"' and Warming notes that it differs from steppe "essentially in the larger dimensions of the constituent plants, and above all, in the presence of

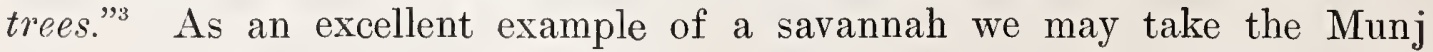
Grass (Saccharum Munja) formation which occupies enormous areas in Northern India.

It is very doubtful whether all savannahs can be classed as xerophilous. Erianthus Ravenno, for instance, forms typical savannahs in Northern India and this species cannot be classed as xerophilous. With the exception of Bamboo formation, indeed, savannah probably represents the highest type of grassland and shows grasses growing under the most favourable conditions of soil and moisture and thus usually indicates a condition of these factors which is suitable for good forest growth.

1 Warmiug, l.c., p 281

2 Plant-Geography, 1903, p. 162.

3 l.c., p. 293. 
9. Warming further recognises an ASSOCIA- The AssoeiaTION as " a community of definite floristic composition within a formation; it is, so to speak, a floristic species of a formation which is an becological genus." A forest, for instance, obviously differs according to its constituent species and this author thus recogniscs deciduous dicotylous forest in the tempcrate climate as a mesophilous formation of which Beech Forest, Oak Forest, and so on, may be considered different associations. He also notes that, as different becch forcsts are not always identical in character, we may recognise varieties of an association.

10. The classification adopted by schimper schimper's differs in some respects from that detailed above. This author also distinguishes Aquatic tion. Plants (Hydrophytes) from Terrestrial Plants but then proceeds to classify the latter as Troprophytes. follows :-

"Contrivances for expediting the exit of water are characteristic of hygrophytes, or plants whose conditions of life exclude all danger of desiccation, and in which a stagnation of the water, which brings nutritive salts to the parts requiring them, may be feared. On the other hand, difficulties in obtaining a supply of water lead to the formation of devices for assisting absorption and limiting transpiration; xerophytes are provided with contrivances of this kind. ${ }^{2}$

He also places in a third category-

"all plants whose conditions of life are, according to the season of the year, alternately those of hygrophytes or of xerophytes. All such plants, including, for instance, the great majority of the plants composing the Central European flora, should be termed tropophytes. The structure of their perennial parts is xerophilous, and that of their parts that are present only in the wet season is hygrophilous."'

He then distinguishes-

Rain-forest (=Evergreen forest) as a hygrophilous formation of tropical woodland and

Monsoon-forest (=Deciduous forest) as a tropophilous formation of the same.

Schimper's hygrophytes and tropophytes as a whole are included in Warining's mesophytes. The Indian Forester will appreciate the wide separation of the tropical evergreen from the deciduous forests of Schimper's scheme.

11. Warming endeavours to carry classifica- Warmingss tion a step further by grouping all formations under a series of classes of which the follow- Cof Forification ing are examples:-

Psammophytes (formations on sand and gravel),

Eremophytes (formations on desert and steppe),

Halophytes (formations on saline soil).

I.c.s p. 145

2 l.c., p. 2.

ᄀ l.c., p. 5 .

[ 111$]$ 
Sclerophyllous formations (bush and forest), and so on.

These classes are frequently very difficult to distinguish and we may obviously have precisely the same formation in a desert (caused by insufficient rainfall) and in a moist climate (on very dry sand or gravel). The Tamarix thickets on sandy river banks in the uoist Indian region of deciduous forests and in the desert tracts of the Panjab may be taken as an example. Similarly saline soil formations may be found on non-saline sand, heavy clay and so on.

Butea frondosa woodlands, for instance, occur both on saline and heavy soils, Tamarix on saline and sandy soils, and so on. Again much of the woody growth on sand, in almost desert tracts and on saline soil, might be classed as sclerophyllous bush. A detailed classification on these lines therefore in the present state of our knowledge tends to become confused and difficult to apply in practice.

Points which require consideration in Ecological Classifieation.
Primary Snldirision into Grassland and Woodland allrisable.
12. In endeavouring to draw up an acceptable scheme of œcological classification the following points demand attention :-

Professor Warming himself clearly states that "the œcology of plants is a subject still in its infancy; numerous investigations must be made before the foundations can be truly and rightly laid, and before a consistent, clear, and natural classification of plant-communities is achieved."

For the present, the main desideratum is undoubtedly a lack of accurate descriptions of the communities which can be readily distinguished in different countries, a lack of complete and accurate information regarding the factors which compose the environment of such communities and want of information regarding the factors of dominant importance which regulate the existence and distribution of the communities.

As a basis for such work it seems undoubtedly preferable to adopt the two great classes of vegetation which Schimper terms wbodland and grassland; in the former woody plants give the character to the type of vegetation and in the latter herbaceous plants and grasses. Schimper also distinguishes desert but here also woody and herbaceous plants exist and the desert can be regarded as the lowest form of grassland or woodland, according to the character of the majority of the plants, and does not need recognition as a separate type of primary importance.

Schimper well says that "woodland and grassland stand opposed to one another like two equally powerful but hostile nations, which in the course of time have repeatedly fought against one another for the dominion over the soil," but the real significance of the relations between these great types, at all events from the practical point of view, appears to lie in this, that, for almost all forms of grassland, there is a corresponding form of woodland and the Forester therefore can often find in the nature of his grasslands the answer to the question of what type of woodland can be introduced with the greatest prospect of success. 
13. It must be clearly understood that only Imuvisable after a far more detailed knowledge of plant-communities has been obtained than we at ilistinguisth present possess will it be possible to adequately appraise their relative importance and thus minor (Ecoloto evolve a really satisfactory classification and for this reason it seems impossible and inadvisable to insist on any distinction at present between formation, association, and minor groups. All that seems immediately necessary is that those ocological groups which exist and which can be readily recognised in different localities as distinct, either on account of a different physiognomy, or habit of growth (tree, shrub, erect, climbing, etc.), a different period of vegetative activity, of flowering or fruiting, a different admixture of species, or on account of marked differences in the dimensions attained, in the density of stocking, state of repreduction, and so on, should be separately described and, for the present at all events, these may conveniently be termed communities. As our knowledge increases these can be subsequently aggregated into larger groups or disintegrated into smaller groups, as may seem advisable.

14. Every type of vegetation is to a greater or Formations less extent able to increase the quantity of soil available in a locality and to increase the are not capacity of that soil for retaining moisture through the addition to it of humus. Rocks ${ }^{\text {nermanent. }}$ are gradually weathered and broken up by the mechanical action of heat and cold and the chemical action of the atmosphere and water. Plants also to some extent aid in this work of decomposition by keeping the rocky surface moist, by the eroding action of their absorbing roots and by the mechanical action of those roots which penetrate into cracks and crevices and which by their continued growth are able to split the rock. Plants however are of still greater importance in this respect owing to their power of accumulating in their neighbourhood wind and water-borne dust and débris and of resisting erosion. It is thus clear that the continued existence of plants in a locality may alone be sufficient to convert a xerophytic into a mesophytic habitat and the gradual covering of naked rock with luxuriant vegetation through a succession of (1) Algæ, lichens and mosses, (2) Xerophilous grassland or woodland, and (3) Mesophilous grassland or woodland has been frequently emphasized by œcologists.

Again plants which are able to resist the injurious effect of a considerable degree of shade and which are in consequence able to establish themselves on the ground already occupied by other plants frequently have more moisture available for their growth and development than those plants which establish themselves directly on bare unoccupied areas, owing to the absence of shade and humus in the latter.

Shade-bearing species therefore are frequently hygrophilous, or mesophilous, and are able to enter into the composition of what must be regarded as a higher type of vegetation than that which is usually constituted of light-demanders.

A succession which thus proceeds from a xerophilous to a mesophilous and finally a Progressive hygrophilous type of vegetation, i.e. from a simple to what must be regarded as a more ${ }_{\text {Succession. }}$ highly developed type, may be termed a progressive succession. Such a succession may. 
probably be recognised in $(a)$ the xerophilous light-demanding woodlands of A cacia Catechu in the stony, sandy, riverbeds of Northern India, $(b)$ the dry miscellaneous forests of the same region, in which the proportion of $A$. Catechu has diminished and a number of additional species have made their appearance of which several have a marked power of increasing the humus content of the soil, e.g. Ehretia lavis. Holarrhena and Adhatoda Vasica. Such woodlands are clearly less xerophilous than the pure woods of Acacia. $(c)$ the markedly mesophilous shade-bearing Sal forest in which the sal predominates. This type of vegetation also extends, in parts of Bengai and Assam, into the region of the hygrophilous tropical evergreen forcsi which must be regarded as the highest type of woodland. ${ }^{1}$

On the other hand the reverse succession from a highly developed to a more simple type may be termed regressive. An example of such a succession is seen when mesophilous forest is cleared, or more gradually destroyed by fire and grazing, on steep slopes, the resulting erosion converting the area into a rocky hillside only capable of supporting the poorest and most xerophilous types of vegetation. Fire is a very potent factor in causing regressive successions, for not only is it capable of temporarily depriving the soil more or less completely of its covering of vegetation, but it also directly dries the soil and destroys the humus. Fire may in this way be responsible for the existence of xerophilous grassland, or woodland, in localities which once supported mesophilous, or possibly hygrophilous, regetation.

Grazing again, by destroying the undergrowth and keeping a forest open, may so reduce the humus content of the soil as to render impossible the reproduction of the mesophilous species constituting the forest and may thus cause a regressive succession.

The effect of artificially clearing an area of its covering of vegetation in this connection is often insufficiently appreciated although this is of vital importance to the Forest Officer. The entire removal of the tree-growth on an area, such as takes place under the treatment of clear-cuttings, or coppice-fellings, results in the drying of the soil, the rapid disintegration of the humus already contained in it and a temporary interruption in the supply of additional humus. In this way the capacity of a sandy sois to retain moisture may be greatly reduced, while a clayey soil becones denser, less aerated, liable to waterlogging in the rainy season and to become very dry at other seasons owing to the moisture which is evaporated not being replaced rapidly, on account of the sluggish movements of water by capillarity in the dense soil. Conditions may therefore be thus created which are unsuitable for the development of young plants of the species which composed the original woodland. It is therefore easy to understand from this point of view why, in certain

1 Nothing said above regarding the details of a succession which under certain curcumstances may occur must be taken to mean that a succession must necessarily almays follow the same sequence, or that a Sal forest, for instance, can ouly establish itself on ground previously occupied by Acacia or certain other miscellaneous species. On sandy soil in the locality dealt with in the present paper steps $(a)$, (b) and $(c)$ of the sirccession described ahore can be clearly recognised, but, on the other hand, it is certain that all the Sal forests of the locality have not originated in the same way. There is, for instance, little doubt that the Sal can naturally establish itself in this locality (1) directly on sandy or well drained clayey soil, provided suffeient moisture is available by percolation or otherwise, (2) on sandy soil after a directly on Mants like Adhatoda has considerahly increased its humus content, $(3)$ on clay which has supported a growth of plants like $4 d$ hato ar Trewia nudiflora, and others. The texture of the clay is improved by the draining action of the roots of these plants and by the admixture of humus so that the acration of the soil is improred and the movement of water from the subsoil to the surface by capillarity is facilitated. 
localities and for certain species, methods of treatment which result in the more or less complete removal of the vegetative covering are unsuitable, while a method of trcatment like the Selection System under which the exposure of the soil is reduced to a minimum is the most successful.

A point, also, which is frequently not appreciated is that, by making clearings in the middle of woodland, conditions are often created which are quite unsuitable for the healthy development of the species composing the surrounding woodland and which are caused by the absence of free air-circulation.

The grassy plains, so common in the Sal forests of India, frequently illustrate this point. These areas are usually clearings which were originally made in the forest for cultivation and then abandoned. Owing to the absence of air-circulation caused by the surrounding forest belt, such areas are intensely heated by the sun in the day and hot seasoil and cooled by radiation at night and in the cold season. In dry localities this action is intensified and in such places the stool shoots, springing from any stumps of the felled trees which happen to have been left in the ground and to have survived, are annually cut back by frost, while the absence of humus and dryness of the soil prevent the establishment of new seedlings. The natural re-establishment of the mesophilous Sal forest is therefore rendered impossible, except very slowly in the narrow belt immediately adjoining the forest. The Forest Officer who wishes to quickly afforest such areas, therefore, will be most successful if he recognises the fact that a regressive change has taken place, that a habitat which recently supported mesophilous vegetation has now become strongly xerophytic and that xerophilous and frost-hardy species like Acacia Catechu should accordingly be introduced.

Coppice fellings in the middle of forest growth may similarly cause a regressive succession.

Finally there is a type of succession which we may distinguish as parallel succession. parallel

Types of both grassland and woodland are found in all kinds of habitats, ranging from Succession. the most xerophytic to the most hygrophytic, and it is of great importance for the Forest. Officer to realise that, for each type of grassland, there is, as a rule, a corresponding type of woodland capable of thriving under similar conditions of the environment, seeing that this has a direct bearing on the question of afforesting grasslands. When a type of grassland, such as Munj savannah, is replaced by a parallel type of woodland, e.g. dry miscellaneous forest of Acacia Catechu, Dalbergia Sissoo and others, we may therefore regard it as a case of parallel succession to distinguish it from the progressive and regressive changes considered above.

Parallel changes can be frequently effected more easily and rapidly than progressive changes and with reference to such questions as the afforestation of grasslands and the extension of woodlands parallel changes are probably as a rule of more practical importance. 
15. It may be asked that if such parallelism really exists between grassland and woodland as has been indicated above and if the existence of a certain type of grassland in a particular habitat really indicates that that habitat is suitable for a certain type of woodland, how is it that we do not find this woodland already in existence there and how is it that the grasses are able to remain in possession? The answer to this question is to be found, it is believed, in the exceedingly efficient mechanism for seed-distribution by wind, and probably also to a considerable extent by water, possessed by grasses by means of which they are frequently enabled to reach unoccupied ground before woody plants. Anyone who has watched the wind blowing across a munj savannah, several' miles in extent, and wafting the myriads of tiny cottony fruits in every direction far and wide, finds no difficulty in realising the undoubted fact that to a great extent the banks of alluvial deposits thrown up by the rivers, aithough suitable for the growth of such trees as Khair (Acacia Catechu) and Sissoo (Dalbergia Sissoo), are first seized on and occupied by the munj. Once grassland has thus gained possession it is obvious that the establishment of woody plants becomes more difficult seeing that their seedlings have to face a competition with the grasses both in the soil for moisture and in the air for light. A very clear case where an area of recent alluvium has been first colonised by munj in this way but from which it has later been driven out again by the khair has been seen by the writer in an area at the foot of the southern slopes of the Siwaliks near Mohan. In part of this area munj is still dominant and vigorous, but young plants of khair are just appearing scattered here and there, in other portions the khair are more numerous, larger and older and many of the munj clumps between them can be seen dead and dying, while elsewhere a dense pure polewood of khair has become established under the shade of which can still be seen the decayed remains of the munj clumps which had first colonised the spot.

The same thing has been observed in other types of woodland and grassland and it is believed that, as a general rule, woodland soon succeeds in nature in ousting the corresponding grassland from its habitat unless this is prevented by local factors such as fire, grazing, frost, or by factors which prevent the formation and efficient distribution of good seed.

In considering the ailar. tatious and distribution of Plants it is neeessary to undne prominenee to a single Factor.
16. It must neven be forgotten that the principal problem which œecology has to solve is to supply an answer to the question "why each species has its own special habit and habitat." CEcologists in regarding water as the factor which "plays the leading part in determining the creation of plant-communities and their distribution over the soil " are apt to lose sight of the fact that a plant's environment is composed not of a single factor but of many factors and that each plant must be perfectly adapted not only to the available water supply of its habitat but also, and no less perfectly, to the conditions of light, temperature and other factors to which it is exposed. Hence although we see that a plant is clearly adapted as regards its periodicity, habit of growth and structural peculiarities to survive in a habitat where certain moisture-conditions prevail, we must guard against the idea that the available water supply has necessarily. [ 16 ] 
been the dominant factor responsible for the fact that that plant is only able to exist in certain habitats and not in others, i.e. for its distribution as we now find it.

Differences in the amount of available water for instance offer no obvious explanation of Neeessity of such remarkable facts as that, in the deciduous Indian forests, on the same soil and in the Supra-maxisame climate, some species like Schleichera trijuga, Bassia latifolia, and others, come into mare may full vegetative activity in the hottest dryest season of the year, while the majority, like Teak, be responsiwait until the near approach of the monsoon insures an easy and plentiful water supply. partienlar If the water supply is here the factor of dominant importance what advantage can have been gained by the plants which first showed a tendency to become active in the hot season, which can have accounted for the evolution and survival of such species? No such advantage can I think be shown from the point of view of the water supply, but there is a real advantage from the point of view of temperature. Transpiration undoubtedly reduces the temperature and it is quite possible that some species avoid the risk of a rise of temperature above the supra-maximal by transpiring actively during the most dangerous season of the year, although other species are able to exist with different periods of activity, owing to their being less sensitive to injury from high temperatures, to their possessing more adequate protective arrangements during the resting season, and so on. ${ }^{1}$

A most remarkable fact which possibly indicates the importance of active transpiration during the hottest season is that in the swamps of the Dehra Dun valley, at an elevation of less than 2,000' above Mean Sea Level, the following temperate species occur, which are usually found in the Himalayas at an elevation of $4,000^{\prime}$ to $8,000^{\prime}$, and this may be due to the fact that vigorous transpiration is possible in the hot season owing to the abundance of water available :-

\section{Hedera Helix which often ascends to $9,500^{\prime}$ in the Himalayas and Quercus incaria.}

17. Again if we consider the danger from Xerophilous infra-minimal temperatures, no Forester who has had experience of the forests of Central tharaeteris. and Northern India would be inclined to doubt the immense importance of frost as a factor regarded as influencing the distribution of trees and it is a remarkable fact that almost all the adapta- adaptations tions noted in paragraph 7 above as tending to reduce transpiration and to be characteristic ture eondiof xerophytes also tend to reduce liability to injury by frost and low temperatures. The reduction of the radiating leaf surface and the movements of leaves and leaflets reduce radiation, while protective coverings of sclerenchymatous tissue, cuticle, cork, wax and hairs all protect the living tissues from contact with chilled external air.

It should be noted also that two of our most typical Indian xerophytes are also two of our most frost-hardy species, viz. Acacia Catechu and Zizyphus Jujuba. Just as these adaptations moreover may be of service in affording protection from extreme cold, to scarcely less an extent may they be of service in affording protection from extreme heat.

${ }^{1}$ Plant-competition is also a factor which may possibly be responsible for the evolution of the remarkable periodicity noted above. Species capable of growth at seasons which are unfavourable for the majority of plants may, on this account, be able to surrive and hold their own in the struggle for existence with more vigorous plants, the period of vegetative activity of which, however, is either shorter or occurs altogether at a different season. 
The presence of ethereal oils also often appears to have a remarkable effect, at all events in regard to low temperatures, and during the phenomenal winter of 1904-05, when all indigenous woody plants suffered more or less severely in Dehra Dun, the plants which showed the most conspicuous immunity were the exotic Cinnamomum Camphora and Eucalyptus citriodora.

The fact here emphasized that the so-called xerophilous adaptations may be of great utility in enabling a plant to withstand extremes of temperature is obviously of practical importance, inasmuch as xerophilous plants are in consequence the most suitable species to introduce in localities not only where there is a scarcity of available water and a probability of damage by drought but also where there is a danger of injury by extreme heat oir cold.

In this connection it must be remembered that the mere presence of water in the habitat of itself directly tends to reduce the danger from extreme temperatures. The presence of water vapour in the air tends to reduce both solar and terrestrial radiation and the presence of water in the soil similarly tends to maintain an equable soil temperature.

It is instructive to note that non-indigenous mesophilous and hygrophilous species of bamboo which have been introduced and grown successfully in comparatively moist and protected localities in Dehra Dun have been destroyed or greatly injured by frost in exposed grasslands such as Ramgarh Tappar.

Such a character as the possession of a thick corky bark, also, may often be of special utility in the way of decreasing danger from fire damage.

18. Even if such adaptations as the above can be proved by experiment to be the ordinary response of the plant to the stimulus of a variation in the water supply, this does not alter the fact that, in many cases at least, the vital importance of such adaptations lies in this, viz. that they enable the plant which has learnt to respond to this particular stimulus in this particular way to resist extreme temperatures and thus to survive in the struggle for existence, while other plants which responded in a different way, no less efficient as regards securing a sufficient water supply, but failing to afford the necessary protection from temperature, perished. Seeing therefore that the main object of œcology is to explain "why each species has its own special habit and habitat," it is obvious that we should avoid as far as possible laying undue stress on a single factor, however important in itself, but which in a multitude of cases is probably not the dominant factor responsible for the existence of forms of vegetation, as we now find them in their natural habitats.

Importance of light.
19. As indicating how an insistence on the primary importance of the water supply may quite possibly obscure the vital factor of dominant importance, we may take the case of those evergreen trees which exist in regions of moderate rainfall, such as Laurus nobilis, Ilex aquifolium and Prunus Laurocerasus in the Mediterranean region and species of Persea, Laurus, Phœbe, Ilex and Myrica in the Canary Isles, which are characterised by a more or less xerophilous type of foliage and [ 18 ] 
which are believed to owe their ocological peculiarities to a deficiency in the summer rainfall and to the fact that they must remain active through the winter to utilise the rain falling at that season. Such plants are consequently supposed to be peculiar to regions where rain falls chiefly in winter. Speeies of Ilex, Persea, Phobe and Myrica however all occur in India in regions where the rain chiefly falls in summer, the season when the majority of the associated species show their maximum activity. The Sal tree also curiously enough is practically evergreen and its foliage is unusually xerophilous for a mesophilous species. It will also be noted that all the trees mentioned have a more or less pronounced capacity for standing shade. No Forester doubts the extreme importance of light as a factor capable of influencing the distribution of plants and, in the case of the Sal, its capacity for withstanding a considerable degree of shade is almost certainly the factor of most importance in enabling it to gain a footing in forests of miseellaneous species and to form gregarious forests of its own. Diminution in intensity of light, however, must to some extent mean less assimilation and therefore less vigour for growth and vital funetions, and from this point of view it can be understood why a plant, which has become adapted to the utilisation of diffuse light and which has to compete in the struggle for existence with plants which can utilise light of greater intensity, should find it advantageous to maintain its foliage throughout the year. At the same time the faet that the foliage has to persist through unfavourable seasons and withstand the cold of winter and heat of summer explains why a somewhat xerophilous structure should characterise the foliage. The dominant factor therefore which here seems responsible for the existence of a remarkable type of vegetation appears to be not water but light.

In this connection also it should be noted that there are several plant characters which Doubtral may be considered adaptations to deal with light or water. The highly polished surface of many xerophilous leaves for instance may be of service in reflecting some of the incident light, while, on the other hand, it may be of use in dealing with excessive moisture, in causing the water to run quickly off the surface. A covering of pilose hairs is similarly doubtful :-

"The epidermal cells project as countless papillæ which give to the leaf a velvety appearance. Between the papillæ the water rapidly spreads by capillarity as a thin film extending over the whole leaf blade, so that the water can evaporate more quickly than if it were not thus spread out. The opinion has also been expressed most recently that these papillæ serve to increase the amount of light supplied to the leaf."

20. Again, whatever may be the degree of Action of adaptation exhibited by a formation to the conditions of moisture now prevailing in its habi- primarily tat, there is no doubt that in a great number of cases the dominant factor responsible for for the

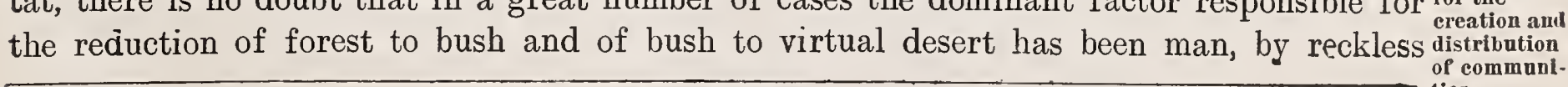


fellings on hillsides and by subjecting woodlands in the plains to excessive grazing and injury by fires. Similarly savannahs and steppes have in many cases undoubtedly resulted directly from forest by fellings followed by fires and in some cases frost and excessive insolation.

It is of importance to realise this for it emphasizes the possibility of reconverting desert, or grassland, to forest by the selfsame agency, viz. man, and shows that deserts and grasslands need not necessarily be regarded as permanent on account of wide differences in climate or soil. While we may therefore utilise such words as xerophilous and hygrophilous as useful terms conveying some idea of the characteristics of a form of vegetation, of some of the conditions of its environment and of the way in which the economy of the plant is adapted to these conditions, we must continually guard against the idea that the available water supply has necessarily been the dominant factor responsible for the existence and distribution of that type. In studying the œcology of any plant or plant-community, we must continualiy remember that its existence and distribution depend on a number of factors to each one of which the plant must be just as perfectly adapted as it is to that of water supply and that a slight change in any one of such factors may suffice to render the continued existence of such a type impossible. If we wish to understand the œecology of any plant, or plant-community, we must study, not only the adaptations of its vegetative members, root, stem and leaf to the water supply, temperature, light, air currents, other living plants and the animals of its environment, but also, no less, the adaptations shown by the flowers and fruit and the arrangements necessary for the production of vigorous seed and its suitable distribution, such as the season which various plants find most advantageous for the production of flowers and fruit and the reason for this.

21. A point that appears to be frequently overlooked in œecological work is that, although the nutrition of ordinary terrestrial plants is carried out broadly on the same main lines, differences in detail undoubtedly exist. There is reason to believe, for instance, that owing to a difference in the osmotic strength of the substances produced in the cell-sap of the root-hairs some species may be able to obtain sufficient moisture from concentrated solutions of salts, or from very retentive soil, whereas others cannot do so easily, and the latter must therefore resort to devices which aim at decreasing transpiration, the storage of water, and so on. If this is the case we should naturally expect to find plants with, and without, obvious xerophilous adaptations in the same habitat. The fact that Butea frondosa which is believed to possess no very remarkable xerophytic adaptations can exist on saline soil and that it is in full vegetative activity during the hottest dryest period of the year on the retentive Black Cotton Soil in the plains of India possibly indicates some such peculiarity. The needs of different species in respect of the quantity and quality of various mineral salts, of the quantity of oxygen for respiration, of the intensity of light for assimilation and of temperature undoubtedly vary considerably and we should therefore naturally expect to find considerable differences in the nature and magnitude of the adaptations exhibited by different species in response 
to variations in the same factor. Very little is known about this and hence of the extent to which structural differences can be relied on to give a correct conception of the intensity of any particular factor of the environment, but we must obviously be prepared to find plants with widely different adaptations existing together in the same habitat and forming a. part of the same community.

22. Connected with the above question also The probiem is the possibility of precisely the same object, viz. successful existence, being attained in of Saecesstu

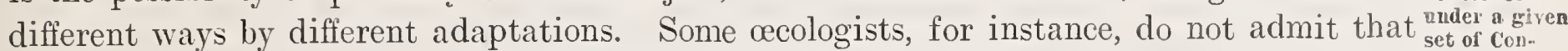
two plants, the one with an obvious xerophilous structure and the other with a hydrophilous ditions may structure, can arise through evolution in nature in the same habitat. Thus Clements ex-more tinan pressly states that "it is impossible for the same habitat to produce both hydrophytes and xerophytes," and he explains the well-known fact that many swamp species exhibit obvious xerophilous adaptations by considering that the latter are stable structures which "were developed when these species were growing in xerophytic situations, and not by the hydrophytic habitat in which the plants are found at present," ${ }^{2}$ in other words he apparently considers that such plants are not in complete harmony with their existing environment. From what is known of the conditions of plant life and the universal perfection of the adaptations developed by plants in response to their environment we should naturally expect that any species out of harmony with its surroundings would, if plastic, rapidly adapt itself to those conditions, or that, if not plastic, it would fail to survive and would therefore not be found existing in nature under such conditions. If, on the other hand, a species proves stable under different conditions of environment we should naturally be inclined to think that no new adaptations are required, in other words that the existing structure is in complete harmony with the conditions of the habitat. In the case of swamp plants for instance the great difficulty in the majority of cases appears to consist in securing an adequate supply of oxygen for the submerged roots. If the oxygen supply is short the normal functions of the roots will be depressed and a diminished water supply will result. This can be met either by increasing the oxygen supply and thus the rate of absorption at the roots, by the provision of more adequate aerating arrangements (e.g. wide air spaces, pneumatophores, etc.) or by diminishing the loss of water by transpiration so that it may keep pace with the slow absorption at the roots and thus there is no reason to believe that plants, exhibiting xerophilous structures designed to diminish transpiration, are at all less perfectly adapted to a swampy habitat, than are plants possessing hydrophilous arrangements designed to increase the oxygen supply. Indeed of the two types of structure the former is probably the most perfect and on the whole the most successful, inasmuch as it may enable a species like Saccharum spontaneum to exist in a very dry and sandy habitat, where there is a great scarcity of available moisture, in a heavy clay soil where there is at some seasons a large quantity of water and little oxygen for the roots and at other seasons

\footnotetext{
l.c., p. 169.

${ }^{2}$ l.c., p. 170.

$\left[\begin{array}{ll}21 & 1\end{array}\right.$
} 
a scarcity of water owing to the slow movement of water by capillarity, and finally in a swamp where there is a maximum of water but very little oxygen, and all this with very slight changes in structure, the leaves of the swamp form still being clearly xerophilous.

If a deficiency of oxygen in the soil tends to depress root activity and thus diminish the quantity of water which roots can obtain from the soil, we should expect a heavy nonaerated soil like clay, or the water-logged soil of a swamp, to be physiologically dry, just as a sandy soil, through the mere absence of water, may be physically dry, and consequently we should expect to find the same species not infrequently on dry sandy soil and on heavy clay, or in a swamp. This is the case and in India Bombax malabaricum, Odina Wodier, Garuga pinnata and others are often found on physically dry, stony or sandy soils and also in swampy localities, while Phyllanthus Emblica, Egle Marmelos and others are often found on dry, sandy, stony, soils, as well as on heavy clay.

It must also be remembered that a clay soil may be physically dry, as well as physiologically dry, owing to the fact that the dense nature of the soil prevents the free movements of water by capillarity and the soil may thus lose water by evaporation at the surface far more rapidly than it can be replaced from the subsoil water below.

It has also been pointed out above that xerophilous structures frequently serve equally well as adaptations with reference to temperature conditions, as to moisture conditions, and it is therefore clear that we must be prepared to find one and the same species provided with a certain set of adaptations existing in a number of different habitats and entering into the composition of a number of different communities. It may grow equally well in different communities; it may be dominant in one and form a small proportion of others; it may attain its highest development in one and show inferior dimensions in another; it may reproduce itself readily in one and with difficulty in another, and so on.

Conrenient to classify Terrestrial plants as Xerophytes. Ilesophiptes and Hygropliytes.
23. With particular reference to the vegetation of India it will probably be found convenient, at all events for the present, to confine the word Hydrophyte to a true aquatic plant, as defined by Warming (paragraph 7 above) and then to subdivide terrestrial plants (including marsh plants) into Xerophytes, Mesophytes and Hygrophytes.

It is necessary however to consider what is really the essential meaning of these terms. Ecologists frequently overlook a fact of great importance, viz. that a xerophilous leafstructure, as a rule, merely indicates that transpiration is slow, that when assimilation is proceeding the actual quantity of water vapour passed off from the leaf in a unit of time is rclatively small, but it by no means follows that the total quantity of water which a plant with xerophilous leaves may be able to utilise during a pcriod of say one complete year is also insignificant. Owing to the fact that a plant with xerophilous leaves is frequently able to remain vegetatively active during periods when another plant with mesophilous leaves is obliged to cease activity, the actual quantity of water utilised in a year, and the vigour of growth, as indicated by the dimensions attained, may be actually greater in the case of the former than in the case of the latter. It is known that, when the 
quantity of moisture in the soil falls below a certain limit, the movement of watcr by capillarity in the soil becomes very slow. It is therefore conceivable that under these conditions the roots of a mesophilous plant, in order to kecp pace with the rapid transpiration from the leaves, will remove watcr more rapidly from the soil than it can be rcplaced by capillarity. Vegetative activity would therefore obviously become impossible. A xcrophilous species on the other hand with its slower transpiration and absorption might be able to continue activity.

It is believed that the savannah grasses Saccharum Munja and S. Narenga, dealt with in this paper, supply an illustration of the point herc considercd. The glaucous, wax-coated leaves of the former are obviously xerophilous, while the dark-green leaves of the latter are comparatively mesophilous. Notwithstanding this fact the former has frequently been seen in the locality dealt with in this paper exhibiting more vigorous growth and attaining larger dimensions than the latter. Plants of both species experimentally cultivated on loam, however, showed that, in February when the moisture-content of the surfacc soil was comparatively small, although both species were growing under similar conditions of soil and moisture, while $S$. Munja was growing vigorously (as judged by actual measurements of the internodes of the culm), S. Narenga was vegetatively inactive.

Warming rightly notcs that "Tropical rain-forest constitutes the climax in the development of vegetation for the whole world." ${ }^{2}$ We may therefore accept the evergreen tropical rain-forest, which Schimper classifies as a hygrophilous formation, as the most highly developed ocological type of vegetation, the xerophilous as the least highly developed and the mesophilous as an intermediate type.

In view of the remarks made above, however, it is obvious that we must not depend on so-called the so-called xerophilous and hygrophilous characteristics of plants as an unfailing criterion xerophilous of the type of vegetation to which they belong, but must consider them also in connection philous with periodicity and therefore regard them rather as an indication of the manner in which ties not in particular plants deal with the supply of water they are able to obtain, hygrophilous charac- criteriou of teristics usually enabling a plant to deal with a large quantity of water in a short time and philons and xerophilous adaptations enabling a plant to utilise its water supply slowly in small plants or quantities. As the true criterion of a xerophilous or hygrophilous type of vegetation, typegetation. however, it seems certain that we must consider the total quantity of moisture which plants are able to utilise throughout their existence and this would be approximately indicated by the vigour of growth and dimensions attained. On the whole it seems probable that the best factor to accept would be the actual dry weight of organic material produced per unit of area at the period when the majority of the individual plants composing the vegetation have attained maturity. Thus for grassland the weight of dry grass, and for woodland the weight of wood, per acre, would probably be an approximatc criterion of most practical utility, although strictly speaking the weight of subtcranean as well as of aerial parts ought to be considered and also the weight of the leaves and fruit produced by woody 
plants. In the case of woodland we must obviously consider the wood produced by all the species which enter into the constitution of each type and by all the plants existing in both overwood and underwood at the age of maturity. From this point of view it will be seen that, other things being equal in each case, the most hygrophilous type of vegetation will be composed of individuals attaining the greatest dimensions, while vice versâ the most xerophilous type will contain the individuals which show the smallest dimensions; that the most hygrophilous type will include the most densely stocked and the xerophilous type the most open and poorly stocked communities; that the most hygrophilous type will include the plants with the longest period of vegetative activity and the most xerophilous type the plants with the shortest period of vegetative activity; and that the most hygrophilous type. will include the individuals with the most marked hygrophilous adaptations and the most rerophilous type the individuals with the most marked xerophilous characteristics. ${ }^{1}$

'At present, owing to the absence of statistics regarding the weight of organic material produced per unit of area by the different types of vegetation, it is obviously impossible to do more than indicate an approximate classification of communities as hygrophilous, mesophilous and xerophilous, paying particular attention to such characters as the dimensions attained by the constituent plants, duration of the period of vegetative activity, and the density of stocking. Such a classification therefore can only be accepted as tentative and provisional and will be liable to correction as statistics are gradually accumulated.

Classifieation of Woodland, Ba inboos, Palms.

24. Bamboos constitute a peculiar type of vegetation more or less intermediate between grassland and woodland but which is most conveniently dealt with as woodland and of which it is believed that xerophilous, mesophilous and hygrophilous types exist.

Woodland composed of Palms will also perhaps have to be dealt with as a separate type of woodland.

Comifers. Warming places all coniferous woodland into a separate class which he considers xerophilous stating that "the soil upon which coniferous forest occurs varies widely, yet, so far as reliable information is available, it is always physically or physiologically dry." Schimper however rightly points out that "it is by no means admissible to include them (i.e. coniferous trees) among xerophytes, as Warming has done. The term xerophyte may to a certain extent apply to several species of Pinus and of Juniperus of dry, sandy, and stony soils; * * but it does not apply to most species of Abies and Picea, our silver-fir and spruce for instance, which require as much moisture as broad-leaved trees."

Coniferous woodland should be dealt with as a separate type, of which xerophilous, mesophilous and hygrophilous forms probably exist.

\footnotetext{
1 In connection with what has been said above it is interesting to note that, so far as dimensions of plants are concerned, the highest development is attained by evergreen and not by deciduous trees, e.g. the giant trees of the world belonging to the genera Sequoia and Eucalyptus.

2 l.c., p. 310

s.c., p. 564
} 
Similarly in the case of Dicotylous Woodland deciduous and evergreen woodland Evergreen must each be dealt with separately. Of the latter xerophilous, mesophilous and hygro- $\mathbb{F}$ oodland. philous forms certainly exist.

It is probable that as our knowledge extends we shall have to deal separately in this way with other types of vegetation consisting of plants with similar needs, as indicated by close systematic relationship, or of plants which, although not closely related, have adopted a similar mode of economy, as indicated by similar structural differences, habit of growth, periodicity, and so on.

25. It is believed that the attempt to utilise classification the presence or absence of trees as a character to separate different types of grassland, of Grassland. such as steppe from savannah, must result in a purely artificial classification. There are very few regions of the earth where grasses grow where some kind of woody plants cannot exist and it is believed that the presence or absence of trees or shrubs in grassland is usually, as it were, an accident, due to a peculiar combination of local conditions which may, or may not, exist in what is obviously one and the same type of grassland. There is no doubt that steppe can be produced directly from savannah and even from forest by artificial means and on the other hand it is certain that trees may and often do occur in typical meadow.

Areas of precisely the same type of grassland, e.g. composed chiefly of Saccharum Munja, or of Saccharum Narenga, may be found sometimes with, and sometimes without, scattered trees, according as the local conditions of frost, facilities for seed distribution and so on are, or are not, favourable for the establishment of the parallel type of woodland.

Warming considers the meadow as a type of his mesophilous grassland while reedswamp and savannah are respectively dealt with as hydrophilous and xerophilous forms and are placed by him accordingly in inferior classes. When we consider the gigantic dimensions of the constituent plants and the dense stocking of areas carrying reed-swamp and wet-savannah, it is impossible not to regard these as far more highly developed œecological types than the typical meadow. It must also be noted that the peculiar close carpet formed by the vegetation and the moderate dimensions attained by the constituent species (usually not over 3 feet) in what is usually termed meadow is, sometimes at least, an artificial character resulting from grass-cutting, firing or grazing. Any of these agencies can seriously retard and influence the development of grasses. They frequently for instance do not permit the culms to attain their full dimensions and less height growth consequently results; the ground in the immediate neighbourhood of the plants is thus less shaded and more culms are therefore able to develop and occupy the spaces between the individual plants, a close sward being produced in consequence. On the other hand, however, meadow does undoubtedly often owe its characteristics to the peculiarities of the constituent species and in India it may arise as the result of a regressive succession, such as occurs for instance when the firing of moist Saccharum Narenga savannah so dries the loamy soil as to make 
the vigorous development of this species impossible and its place is taken by smaller species such as Andropogon intermedius, Pollinia sp. and others.

For the present it seems advisable to disregard the presence or absence of scattered trees as an important character and to classify grasslands, provisionally, on the basis of the density of stocking combined with a consideration of the dimensions attained by the constituent plants. Disregarding for the present reed-swamp, suvannah would cover the more strongly mesophilous and all the hygrophilous grasslands, meadow might be retained for the less strongly mesophilous grasslands and steppe for all xerophilous grasslands.

So far as domestic animals are concerned, grassland consisting of xerophilous, or the less marked mesophilous, species, as a rule produces the best fodder, hygrophilous fodder being what is usually described as too coarse or rank to be palatable except to such animals as buffaloes. At the same time the less vigorous and the younger the culms and foliage of coarse species, the more palatable as a rule the fodder and hence, firing, which decreases the vigour of the plants and lays bare to the attack of animals the young shoots and leaves as they appear, by depriving these of the protection afforded by the dead leaves and culms, is an expedient which has been resorted to by man from time immemorial to improve the fodder yield of coarse mesophilous and hygrophilous species.

26. Based on the above ideas, the following is suggested as a purely tentative and provisional scheme of cological classification adapted to the vegetation of India which will give some idea of the limits between which the different types of vegetation vary and of the class of vegetation which may be taken as fairly typical of the main groups. As noted above, it is obviously impossible at present, in the absence of definite data regarding the weight of organic material produced per unit of area, to draw a definite line between the various groups, or to define the latter correctly. It is believed, however, that the scheme will facilitate the work of compiling and arranging the descriptions of the various existing plant-communities, without causing confusion by attempting to introduce too much detail; that it will in fact facilitate the collection of further information and data which are essential before a sound classification can be evolved.

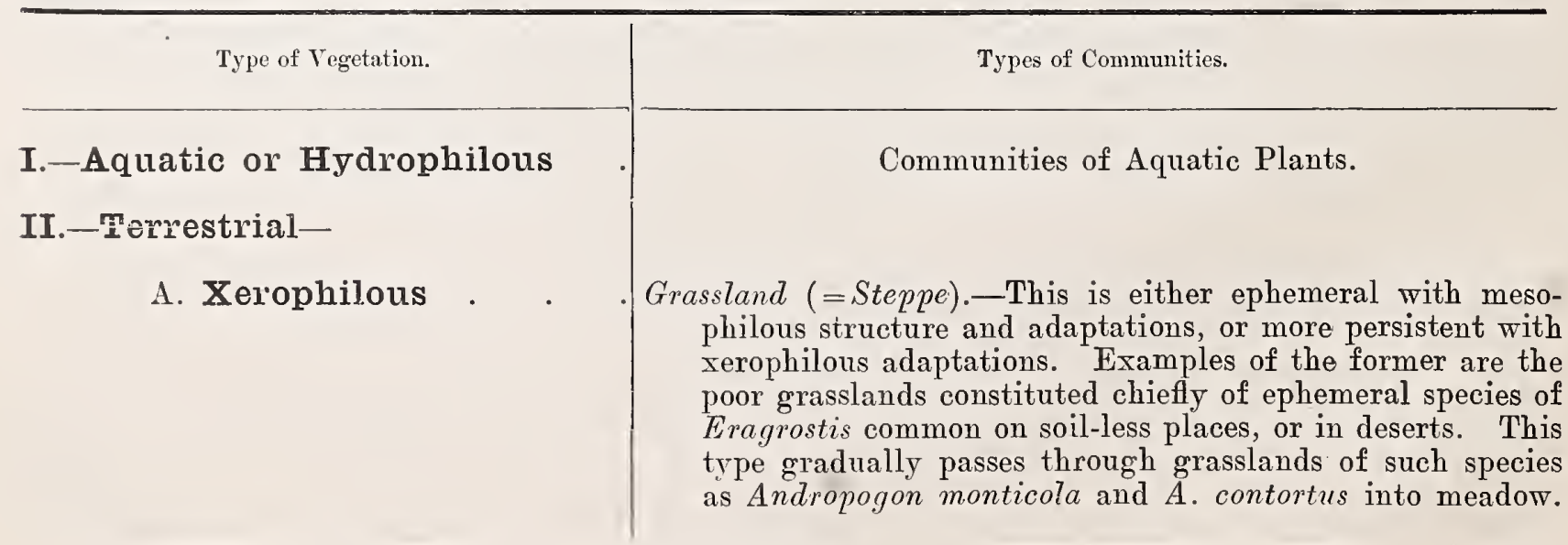




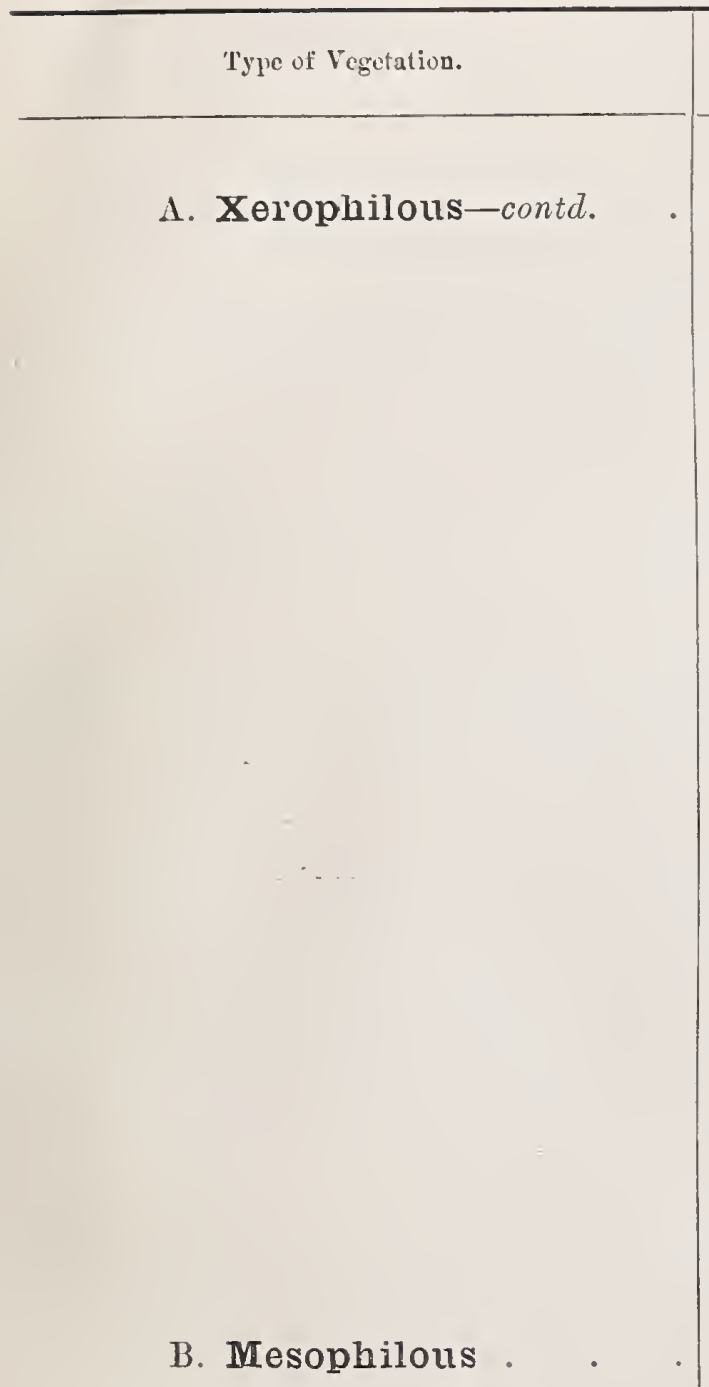

Open grasslands composed of such species as Aristida cyanantha and Triraphis also probably come here, although when densely stocked such types must be perhaps considered mesophilous.

Woodland.-This is also characterised by a short period of regetative activity, or by a longer period with more or less marked rerophilous adaptations.

The dry open deciduous woodlands formed of such species as Cocklospermum Ǵossypium, Sterculia urens, Boswellia serrata, Euphorbia sp. and others come here, also many woodlands of Acacia Catechu, the scrub or bush-growth composed largely of such species as Nyctanthes, Zizyphus and Acacia and the desert communities of Tamarix, Prosopis spicigera, Capparis, Salvadora, Ephedra, Orthanther $a$ and others.

It will be noticed that oniy the poorest type of evergreen woodland comes here, consisting of such species as Salvadora oleoides and Tamarix while Zizyphus Jujuba is also practically evergreen.

Shrubby growth of temperate species such as Arundinaria, Rhododendron lepidotum and $R$. Anthopogon also comes here, while among Conifers some Juniper forests, or bushland, and possibly also some forests of Pinus, e.g. of Pinus Gerardiana, should probably be included in this group.

Grassland (= Meadow or Moist Savannah).-This group includes the Meadows of the Himalayas and of the so-called Hill-Forests of India generally. Of these Duthie writes: "The vast stretches of undulating meadows, known as 'maidans,' and which extend from the upper limits of the forests to the snow line, are somposed of many of the most nutritious grasses of the world, some of them belonging to species well known in Europe for their good grazing qualities."' Here also come the best fodder-yielding grasslands of the deciduous forest areas, while the highest development is probably attained in the Moist Sarannah formed of such species as Saccharum Munja and Saccharum Narenga.

Woodland.-The majority of the so-called "Deciduous-" and "Hill-" Forests of India fall into this group, including most of the Coniferous Forests and most of the Bamboo areas composed of such species as Dendrocalamus strictus.

${ }^{1}$ Fodder Grasses of Northern India by J. F. Duthie, 1888, p.ii.

[ 27 ] 


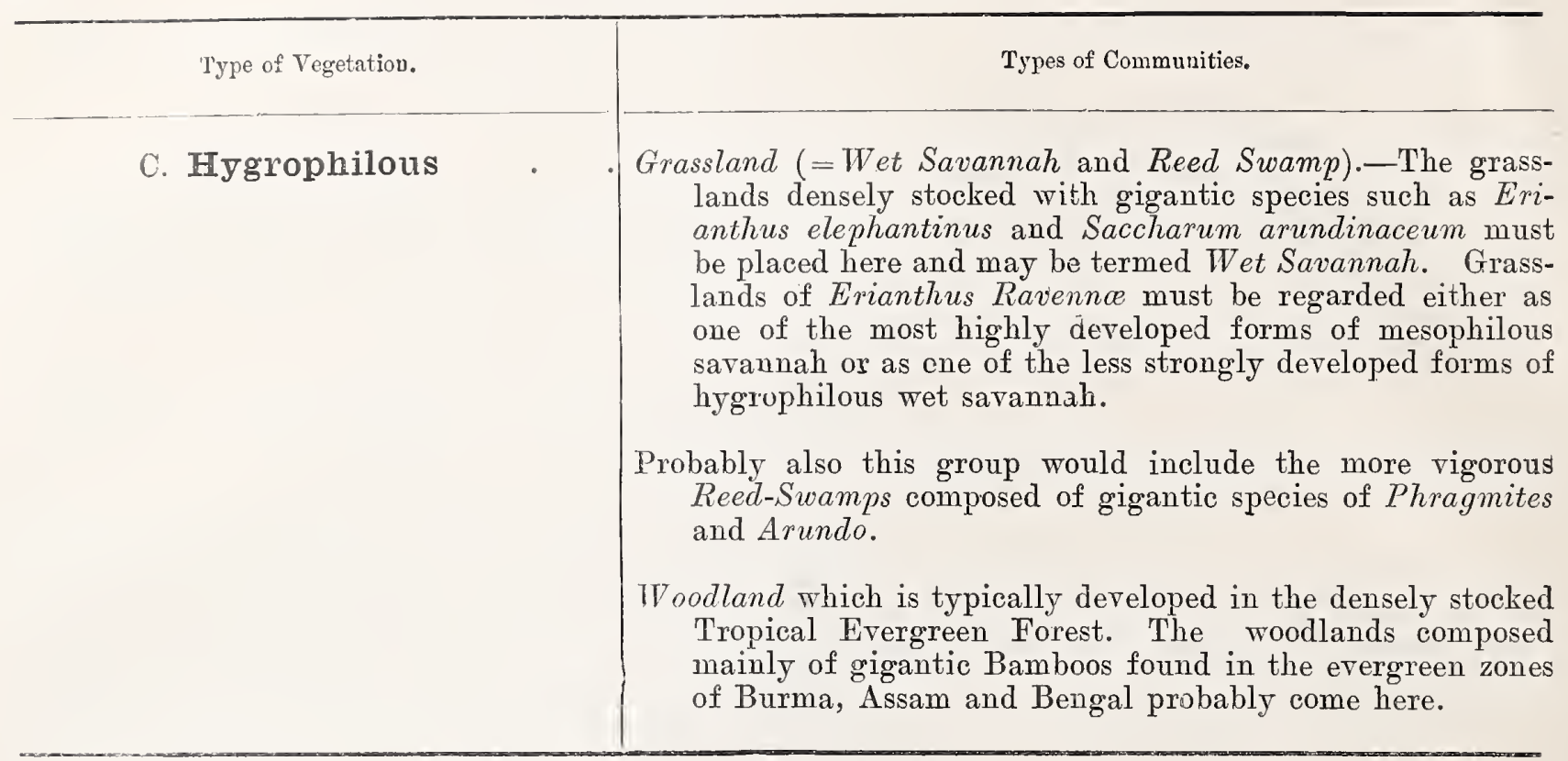

The communities which have been roughly indicated above are merely intended to serve as fairly intelligible types around which those communities which resemble them most closely can be conveniently grouped, but it is at present impossible to describe these communities in full detail, or to accurately define the limits of the groups under which they are classified, for which far more detailed and accurate information is required than is at present available.

27. The scheme of classification which has been sketched above, very imperfect though it is, at all events indicates that, so far as India is concerned, for each main type of grassland there exists throughout a more or less parallel and corresponding type of woodland, both of these types existing under approximately the same conditions of available moisture, as determined by the combined effects of climate, soil, and temperature.

In the case of boch grassland and woodland it will be noticed that the scheme commences with the simplest or most xerophilous form and culminates in the most highly

Value of Ecology for Forest officers. developed type, i.e. with the evergreen tropical forest for woodland, and with the wetsavannah and reed-swamp for grassland.

28. The above somewhat detailed sketch of the scope and objects of the study known as Ecology, together with a tentative skeleton scheme of classification capable of adoption for the compilation and arrangement of the œcological descriptions of the various plant-communities constituting the vegetation of India has been given here, partly because this is required to justify the classification and description of the types of vegetation dealt with in this paper, and partly because, for Foresters at all events, œcology is probably the department of botany of most interest and of greatest practical importance. In secological study a Forester can utilise all the [ 28] 
knowledge he posscsses of Morphology, Ariatomy, Systematic Botany, Physiology, and Pathology to the greatest advantage in the solution of problems of practical importance and the successful solution of which moreover constitutes an important part of his daily duties.

Trained Foresters will find no difficulty in distinguishing and describing the various communities of woodland, a task indeed which forms a part of the duties of every Working Plans Officer, but this work requires to be undertaken systematically and it is obviously advisable to commence the work with special reference to particular species of greatest importance in all the localities where it occurs. Far more attention also must be paid to the accurate determination and recording of the condition of the factors of the locality which constitute the plant's environment in various habitats. The more detailcd and accurate this determination, and the greater the number of the localities in which the observations can be made, the more ccrtainly will the conditions be revealed which are essential for the healthy existence and development of a particular species, and the clearer will be the indication as to the method of treatment which must be adopted if we wish to favour its development and reproduction and to cope with its diseases. It must also be clearly recognised that, in so far as such recorded observations of the condition of environmental factors are correct, they are facts, and as such provide just as satisfactory a basis for a logical conclusion as do experiments. In careful experiments we endeavour to simplify the environment of a plant and in order to test the effect on it of a single factor the latter alone is, as far as possible, allowed to vary and the effect of such variation on the plant is watched. The practical drawback to experiments, however, lies partly in the difficulty experienced in artificially arranging for the isolation of the various factors and partly in the long period of time which is required to obtain accurate information regarding the effect of all the factors of importance capable of effecting the development of a particular plant. Information regarding a single factor alone is of very little valuc and goes a very little way in explaining the facts observed in the field, inasmuch as in nature several factors are in action together and while one factor may be of primary importance in producing a certain result in one case, in another case its action is masked by the effect of a difierent factor which, in its turn, has become of primary importance and responsible for the result obtained.

In recording careful observations regarding the conditions to which a particular plant or type of vegetation is exposed in nature, however, we are doing no more nor less than attempting to read the result of experiments so-to-speak which have been arranged and carried out for us-certain factors have been and are still in operation-the result of this is a certain type of vegetation--and the problem for solution is to answer the query what particular factor or combination of factors from among those in operation is responsible for the result produced?

Moreover, it must be remembered that, whereas experiments with woody plants usually require long periods for the production of valuable results, the work of recording the details 
of 'readymade' experiments can be comparatively quickly done, and by comparing a number of such œcological records it is frequently possible to find several cases in which all important factors, with one exception, have varied very slightly or remained practically constant and thus to directly obtain information regarding the effect of the factor which varied considerably. Even when such comparisons do not at once enable a satisfactory conclusion to be reached they indicate the lines on which an experiment should be organised in order to give the necessary result. An idea frequently prevails that no really valuable information can be obtained regarding such a factor as the quality of the soil, except by detailed and skilled work such as by the chemical analysis of the soil. In the present state of our knowledge of the nutrition of our principal species, however, a chemical analy* sis alone can teach us practically nothing regarding its suitability for a particular species, whereas careful comparative observations regarding the depth of soil, admixture of gravel, sand, clay and humus, moisture content, and depth of water table can be made by anyone and are as a rule, except in rare cases such as where an excess of salts is present, of primary importance in deciding the suitability or otherwise of a soil for a particular species, inas. much as these factors regulate the quantity of water and soluble salts and also of the oxygen available for the roots.

More or less complete data of rainfall and temperature are usually available and the other most important factors constituting the environment of our forest plants are probably winds, light, associated plants, grazing and fire damage regarding all of which comparative chservations of value are possible.

It should also be noted that it is by no means always necessary to extend observations over a wide area before satisfactory conclusions can be obtained. Experience has shown that if observations are made in different carefully selected habitats good results can be obtained in a limited area, e.g. of a single district or division, where the total range of intensity of the various environmental factors, within which the existence of a particular plant is possible, can often be found to be operative, and it must be remembered that local differences in soil and situation are capable of exerting an efiect on the water content of the soil equivalent to that caused by the most arid or humid climate.

While Forest Officers in India have few facilities or opportunities for carrying out and recording the results of prolonged experiments, the work of carefully observing and recording descriptions of the types of vegetation and of the environmental factors which exist in the forests constantly traversed by them on tour is comparatively easy.

Forest Officers in India have a unique opportunity of adding to oecological knowledge which besides being of great scientific value will enormously increase the efficiency of forest management; they have in their charge every type of both grassland and woodland, ranging from the lowest type of alpine or desert grassland to the luxuriance of the evergreen tropi. cal forest.

It is hoped that Forest Officers, realising the possibilities of such work, will do their utmost to systematically publish accurate descriptions and photographs of the chief types 
of vegetation found in their forests and also so far as possible ascertain and record the condition of the environmental factors existing in the various habitats. As regards the ocology of the principal species, also, it is particularly desirable to record careful notes on such points as the periods of vegetative activity, of flowering and fruiting, the agencies by which flower pollination and seed distribution are effected, the time when the seed naturally germinates and the factors which appear of special importance in effecting the development of the young plants during the first few years of existence, as on all these points the maintenance or extension of the area occupied by a particular species, or type of vegetation, largely depends.

29. It is a remarkable fact that, although the Importanee value of the study of mycology and entomology in helping us to secure the healthy develop- of in Ecology ment of our valuable plants is fully recognised, the dominating, importanee of physiology $\begin{aligned} & \text { Plant- } \\ & \text { Diseases. }\end{aligned}$ and ocology is frequently lost sight of and the view is not infrequently held that most plantdiseases of importanee are caused primarily by either fungi or insects.

Every plant-physiologist however is aware of the vital importance to plant-life of sueh primary factors as the available moisture supply, the degree of soil aeration, the temperature, light and competition of other plants and knows that even slight variations in these factors are able to cause disease and death. Notwithstanding this, we have, as yet, no precise knowledge (in the case of any single Indian tree of importance) as to the degree of intensity at which such factors first begin to cause disease and when they must accordingly be considered injurious.

It is important to note, also, that an accurate knowledge of such factors offers every prospect of produeing practical results of value, seeing that the intensity of these factors can be altered within considerable limits by the ordinary operations of practical forestry and thus those conditions may be produced which are necessary for the healthy development of particular plants in cases where such conditions do not exist, or have been destroyed by careless management. Thus the water content of a sandy soil may be increased and its aeration diminished by introducing a speeies with considerable power of humus production such as Adhatoda Vasica, the aeration and texture of a heavy soil may be improved by introducing a species capable of withstanding poor soil-aeration and of producing a good humus supply, temperature can be altered by a judicious use of shelter-woods and by arranging fellings so as to secure good cireulation of air, while plant eompetition may be controlled by introdueing factors such as periodic fires which are unfavourable to the competing plants. On the other hand it is a remarkable fact that, although mycology and entomology are able in many cases to suggest effective remedial and preventive measures which are applicable in agriculture, horticulture and arboriculture, such measures can rarely be adopted in practical forestry, especially in countries where the general value of the produce is small and the forest management not intensive. Frequently the only remedy is to eut out the affected trees and in bad cases to change the species, which is of ten a lengthy and difficult operation, while the new species is frequently less valuable than the 
one it has replaced. Yet even in agriculture the impossibility of adopting cffective direct remedial measures is leading more and morc to the adoption of such indirect methods as the production of new and resistant varieties. Measures such as these, however, are obviously out of place in practical forestry; the forester, as a rule, must take his species as he finds them in nature and if he wants to favour their healthy growth and development he must keep as closcly as possible to those conditions under which they grow best in nature and under the influence of which the species have been gradually evolved.

Morcover to carefully study the requirements and paticntly elaborate the economic treatment of our indigenous species, which we know to be suited to the local conditions of environment, is surely, as a rule, a more rational policy for practical forestry than to try haphazard experiments with exotics on which money has frequently been lavished in the past with little practical result. Such experiments indeed as a gcneral rule merely emphasize the fact that cxotics are usually more liable to diseases than are the local spccies. It is a well-known fact that the most injurious insect and fungal-attacks tend to occur where unnatural conditions of culture have been adopted, such as massing in pure woods species naturally occurring chiefly in mixed woods, and the adoption of mixed crops (i.e. a return to normal conditions of existence) is one of the most practical preventive measures recommended alike by mycologists and entomologists. There is noreover good reason to believe that the expert mycologist, or entomologist, with his ideas concentrated on his special branch of study, frequently fails to rcalise the dominant importance of the primary factors of plant physiology. He may thus be led to believe that a particular fungus, or insect, is the primary cause of a discased state for which in rcality the unfavourable condition of some primary factor, such as available soil-moisture, is really responsible, the fungus or insect being merely a secondary factor and the natural consequence of a sickly condition. In such a case the real remedy should consist in attacking the dominant factor and not the fungus or insect.

In the treatment and prevention of diseases generally the great importance of maintaining the general health and resistant-power of the organism is now usually admitted and this can best be done by studying the eflccts of those primary factors which we know to be capable of directly causing disease and health. This study is capable of giving us the knowledge necessary to manage our forests in such a way that our valuable species will be exposed to the conditions most favourable for their development in nature. Considerations such as the above are gradually forcing practical Forest Officcrs to the conclusion that physiology and œcology at present constitute the richest field for research work which aims at improving the economic management of our forests.

When the post of Forest Botanist was created at the Dehra Dun Forest Research Institute the principal duty prescribed for the incumbent of that post was that of studying the diseases of our important forest species. With the object of attaining the most valuajole results in this direction, for the reasons briefly outlined above, the Botanist undertook the systematic study of the physiology and œcology of forest plants and has commenced 
work with a single species, riz. the Sal tree. It is hoped that, so far as possible, other Forest Officers will do what they can, on the lines which have been bricfly indicated in the last paragraph, to start similar work for other important species.

30. The principal object of the study of objeet of Indian Forest Grasses with which the present paper is immediately concerned is to acquire, Furest as soon as possible, information which will indicate the best treatment to apply to forest grasslands for the purpose of $(a)$ improving the yield of fodder and $(b)$ accelerating their afforestation.

It was recognised that the information required might be obtained by carrying out Wtility of careful experiments.

Forest experiments, however, as noted in paragraph 28 above, usually require long periods for their completion and they cannot therefore supply information of immediate practical utility. In the second place anyone who has attempted to practically carry out a forest experiment knows that it is exceedingly difficult to obtain a result which can with certainty be ascribed to the influence of a single factor, owing to the co-existence of other factors capable of affecting the results; in other words that it is very difficult to obtain accurate information regarding the effect of only a single factor, the way in which it acts and the conditions capable of accentuating or diminishing its action.

In the third place a plant in nature is subject to the influence of not one but a number of factors, each of which, under certain conditions, may be of dominant importance in rendering the existence of the plant, or at all events its vigorous development, impossible.

It is therefore obvious that a few experiments designed with the object of obtaining information regarding the effect of a single factor, such as fire damage, when that factor is of dominant importance, can only give results of very limited practical utility and which are not found to hold good under other conaitions, when some other factor has become of dominant importance.

It is a frequent experience that the results obtained from carefully conducted experiments in one locality, while apparently accounting for the facts observed in that locality, obviously fail to explain the facts existing elsewhere.

Such apparently contradictory results are clearly of little practical value and they are the natural consequence of an insufficient knowledge of all the factors capable of vitally affecting the welfare of a plant in nature. It is only when a good knowledge of all such factors has been obtained, of the way in which they act and of the conditions capable of accentuating or diminishing their action that we can hope to recognise at once which of these factors is of dominant importance in any particular case and what is the best practical treatment to adopt under each set of conditions.

It will therefore be seen that, instead of a few casual experiments, an extensive series of experiments is required in the case of each plant and that such experiments cannot possibly be successfully organised until a preliminary knowledge has been obtained as to what factors appear to be of most importance in regulating the natural distribution of the 
plant in nature, the way in which they appear to act and the conditions capable of affecting their action. The necessity of acquiring a preliminary knowledge of the factors at work in each case, before attempting to organise experiments, or to interpret experimental results, will be more clearly understood perhaps from an example.

In the preliminary work which has been carried out with forest grasses it has been ascertained that while Saccharum Munja may be killed out by repeated early firing on sand, early firing on loam is practically innocuous. Also that although Andropogon monticola may be more or less injured by an early fire on sand, repeated early firing on such soil may result in this species becoming dominant on areas formerly occupied by a more vigorous species Saccharum Munja, owing to the fact that the latter is liable to suffer more severely by fires. If such points had not been ascertained by preliminary field work, it is practically certain that experiments would have given incomplete and apparently contradictory results, whereas when such points have been ascertained from field-work they can subsequently be checked and confirmed by suitably organised experiments as opportunity occurs, when this is considered desirable.

The view which has been emphasized above then consists in this that forest cxperiments cannot, as a rule, be properly organised in such a way as to give results of practical value and of wide application and the results obtained from such experiments cannot as a rule be correctly interpreted until careful and extended field observations have first indicated the principal factors which are at work and the way in which they act.

In addition to the above considerations also, owing to the recent organisation of the Research Institute, the Botanist had not the staff required for the organisation and conduct of extensive field experiments.

31. While the capacity of forest experiments (on the scale on which they are usually conducted) to supply satisfactory evidence regarding the effect and importance of various factors is frequently over-estimated, the importance of careful and systematic field observations on the other hand is often not sufficiently appreciated.

Importanee of careful Field Obser vations.

It has been pointed out in paragraph 28 above that satisfactory evidence can often be obtained by careful and systematic field observations. In a wide series of observations in which all important factors are constant, or vary only within very narrow limits, with the only exception of a single important factor which varies considerably, if the growth and vigour of a particular species is invariably found to vary in direct proportion to the variations of that single factor, it is logical and permissible to conclude that such a varia-tion of growth has been caused by the factor in question and such a conclusion is obviously of great practical importance.

Difficulty is of course experienced in the case of factors which are closely correlated, such as the intensity of light and the amount of available moisture, when dealing with species for which the possible range of intensity of both factors is very limited, seeing that a given condition of growth may frequently be due as much to one of these factors as to another. It is however perfectly possible to arrange a series of observations in the forest 
where the water supply is ample on account of percolation or otherwise but where the light varies, and similarly a serics of observations where the light is obviously ample but where the watcr supply varies, and thus to assess separatcly the cffect of each factor. An interesting point arose in this connection with the observations carricd out during the present work regarding the effect of light on the development of Erianthus Ravenna.

Several cases were noticed in coppice areas wherc the growth of this specics was obviously inferior and this was at first ascribed to the slight latcral shade cxisting in the habitat. Further repeated observations showed that considerably denscr shade than this had no marked injurious effect provided ample water was available and the inferior growth noticed was thus eventually shown to be mainly duc to the drying of the soil by the numerous superficial adventitious roots developed by the coppiced trecs. Similarly it is quite possible to arrange for a scries of obscrvations in nature in localitics where the light intensity varies greatly but where the temperature varies slightly and vice vers $\hat{a}$, although the artificial isolation of these factors in experiments usually offers considerable practical difficulties.

While field observations can thus be arranged in such a way as to obtain information regarding the individual action of each factor of importance, they offer this great advantage over experiments that they enable information to be obtained regarding all the factors of primary importance far more quickly than would be possible with experiments.

The way in which the distribution of a particular plant depends in nature on a complex of factors all acting together, so that in one place one factor is of dominant importance and in another spot an entirely different factor, has already been briefly alluded to in paragraph 28 above and from this it will be clear that whereas ocological observations in the field can give us information, often very little less accurate than that yielded by experiments regarding the individual action of isolated factors, they give us an incomparably better idea of-

(1) what factors are of primary importance in the case of any particular species,

(2) what is the approximate degree of intensity of each such factor which in itself may suffice to cause obviously unhealthy or inferior growth of that species,

and they thus enable us to explain the facts of plant distribution, to suggest suitable methods of treatment calculated to improve the development of various species, to prevent their diseases, or to decide on what species can be grown with most success in a particular locality, far more rapidly and satisfactorily than can the results of a few experiments dealing with the effect of one or two factors.

32. It was thereforc decided that the objects Lines of of the proposed work in connection with forest grasses could be most satisfactorily in Study of attained by-

(a) Selecting a few important species of grass which arc widely distributed and Forest Grasslands. which tend to be dominant over large areas. 
(b) Studying the selected species carefully in the field in their various habitats and compiling for each species a careful œcological record showing the conditions under which it is found to grow vigorously and unsatisfactorily, respectively, in nature, special attention being paid to the character of the soil, the available moisture, light, vigour of associated species, grazing and fire.

(c) Cultivating the selected species during at least one entire season, noting the normal habit, periodicity, development and growth of the culms in the experimental garden and comparing this as far as possible with what was observed to be the usual development in the forest. By examining these species carefully on areas which have been fired at different seasons and in different habitats and by there noting the direct damage done by fire and its effect on the normal development of the plant.

(d) Studying the conditions affecting the growth and development of seedlings of the tree species with which it is desired to afforest grasslands as far as possible, i.e. of the Sal.

It was believed that the above would quickly supply information which would be of immediate utility-

(1) in indicating the best treatment to be appiied to forest grasslands,

(2) in indicating the lines on which a comprehensive scheme of experiments could be satisfactorily organised and carried through, for the purpose of testing the correctness of the conclusions which had been based chiefly on field observations and of supplying additional information which could not be obtained satisfactorily from field observations.

The work done therefore up to date has been carried out on the above lines.

Owing to the recent organisation of the Research Institute and to the lack of the necessary staff and appliances it has been found impossible, up to date, to do more than carry out a few rough preliminary experiments and control cultures, or to determine instrumentally in the field the exact intensity of such factors as available moisture, light, temperature and the proportion of sand, clay and humus in the soil. The observations which have been nade, however, have it is believed been sufficiently accurate to give results of practical value.

The œcology of sal seedlings is a study which has been only just commenced and as this study is continued it is hoped that with reference to it, at all events, instrumental observations will in all cases be feasible, perhaps with the help of the students of the Imperial Forest College, and that a more accurate determination and more precise defini1.ion of the intensity of the various factors will thus be possible in future work.

Species

Selected for Study.
33. It was advisable as far as possible to select not only those species which are widely distributed and markedly gregarious, but also those which are of economic value, so that their œcological study might also incident- 
ally provide information of cconomic value on such points as the best treatment to adopt in areas where a grass like Saccharum Munja is worked for munj fibrc, or for papcr material, the best specics to cultivate for the purpose of fixing sand or unstable soil, the kind of locality in which a valuable fodder grass like Andropogon monticola can be cultivated with most prospcet of success, methods to adopt with a view of cradicating troublesome species which have taken possession of valuable agricultural lands, and so on.

Another point borne in mind also is that, so far as possible, when an important specics is being studied, other specics of less importance, occurring in the same locality and likely to be mistaken for it, should also be studicd and fully described and illustrated, special attention being paid to characters which can be easily recognised in the forest and which scive to distinguish the important from the unimportant species.

For these reasons the following species were selected for study :-

Saccharum spontaneum,
Saccharum Munja,
Saccharum Narenga,
Erianthus Ravennce,
Imperata arundinacea,
Aristida cyanantha,
Triraphis madagascariensis,
Andropogon monticola.

In subsequent papers it is hoped to deal with the Bhabar grass (Ischcemum angustifolium) and the valuable odoriferous oil-grasses.

34. The information collected regarding srrangeeach species has been arranged under the following heads :-

(A) Botanical Description.

(B) Taxonomy.

(C) Biological and CEcological Notes-

(a) Habitat.

(b) Development of Culms, Season of Vegetative Activity and Flowering.

(c) Susceptibility to Fire Damage.

(d) Utility as Fodder and best Treatment for Fodder Production.

(e) Relations of Grassland to Woodland.

(D) Economic Uses.

This paper has also been divided into three chapters, the first containing a brief description of the locality, the second containing the detailed information referring to each species and the third containing a summary of the work done in the form of suggestions regarding the practical treatment of grasslands.

35. The identification of grasses from the lliustrations. brief written descriptions given in a work like the Flora of British India is often found 
difficult and troublesome by the average Forest Officer and it is hoped that the stress which bas been laid on characters easily recognised in the forest and the drawings and photographs which have been given of each species will facilitate the work of identification. In most cases a measuring rod, showing lengths of 6 inches, painted alternately black and white, have been included in the photographs, so that the dimensions of the plants and their various parts can be easily obtained. given for each species to the following works :-

37. The writer's most cordial thanks are due to Colonel Prain, Director, and to Dr. Stapf, Curator, of the Royal Botanic Gardens, Kew; also to Captain Gage, Director of the Botanical Survey of India, and to Mr. E. G. Baker of the British Museum, who have with unfailing courtesy given him the most generous assistance on all points referred to them.

The writer has also to acknowledge the great assistance received by him from the splendid herbarium, mainly accumulated and arranged by Mr. J. F. Duthie and containing valuable collections contributed by many Forest Officers, which is now in charge of the Forest Botanist at Dehra Dun. 


\section{H A P T E R I.}

\section{Description of Locality.}

38. The locality in which the species included Topograply. in the present paper have been chiefly studied comprises the Dehra Dun valley and the northern slopes of the Siwalik range which bound that valley on the south, these together forming a portion of the Dehra Dun Civil District, and also the southern slopes of the Siwaliks which are included in the Saharanpur Civil District. This tract lies between Long. E. $77^{\circ} 40^{\prime}-78^{\circ} 22^{\prime}$ and Lat. N. $29^{\prime} 55^{\prime}-30^{\circ} 32^{\prime}$, and the principal part of it is shown in the map which forms Plate I.

The elevation above mean sea level varies from $900^{\prime}$ to $3,000^{\prime}$. The Dun valley is divided into two approximately equal portions, the Eastern Dun lying to the south-east of Dehra cantonment which drains into the Ganges, and the Western Dun lying to the north-west of the cantonment which drains into the Jumna. The Asan River flowing close to the foot of the northern slopes of the Siwaliks constitutes the main line of drainage in the latter, while in the former the Suswa River occupies a corresponding position. The chief tributaries of the former are the 'Tons, Suarna Rau, Chor Khala and Sitla Rau and of the latter the Bindal, Rispana, Song and Jakhan Rau, ali from the Himalayas. The upper slopes of the Siwaliks consist mainly of sandstone and conglomerates with some clay beds, the lower slopes and the entire Dun valley are covered with the débris brought down from the Himalayas, or from the Siwaliks themselves, consisting of boulders and sand, mixed with which are clay beds of varying thickness.

Where the impermeable clay bands crop out, swamps are often found, but owing to the great thickness of the pervious boulder and sand deposits the subsoil water level is frequently at a great depth below the surface. In the Dun valley owing to the masses of débris brought down from the Himalayas the greatest thickness is naturally in the north of the valley near the foot of the Himalayas, and Fernandez notes: "It is for this reason that the permanent level of water is at such a great depth, the well at the cutcherry at Dehra being 228 feet deep." Another striking feature of the locality consists in the peculiar character of the streams by which it is drained.

The tributaries of the Asan and Suswa rivers which rise in the Himalayas and Siwaliks and the streams which drain the southern slopes of the Siwaliks are, with the exception of one or two of the largest, such as the Song, dry during the greater part of the year and their exposed beds of boulders and sand, often of great width, are then a conspicuous feature of the landscape.

\footnotetext{
1 Working-Plan of the Dehra Dun Forests by E. E. Fernandez, 18s9, p. 10.
} 
Fernandez remarks:-

"This absence of water at the surface is characteristic of all the streams of the Dun, and is due to the great depth of the loose mass of boulders and shingle into which the water sinks, to reappear only where the underlying impermeable band of clay comes up near the surface. Thus even the Suswa and the Song rivers become dry for several miles of their intermediate course."

These streams become mountain torrents in the rainy season, quickly rising and falling after heavy rain, and then bring down masses of boulders, shingle and sand which they deposit as they flow along.

These streams also continually change their course and, leaving behind their former alluvial deposits to gradually become covered with vegetation, proceed to erode new channels and form fresh deposits elsewhere, in the course of which areas often carrying valuable forest may be entirely swept away and fertile fields overwhelmed with boulders and sand.

This continual denudation and deposition is more or less characteristic of the entire Sub-Himalayan tract which contains some of the most valuable Indian Sal forests, and in the locality now dealt with, omitting the dry wind-swept higher slopes and ridges of the Siwalik range which carry comparatively valueless stunted forest, three main types of topography, each of which is capable of supporting a distinct type of vegetation, can be more or less clearly distinguished as below :-

I. Areas where the soil, at least during some months of the year, tends to become more or less water-logged and which in their extreme development become perennially wet swamps. The soil as a rule contains a considerable proportion of clay.

II. The dry alluvial deposits of sand, gravel and boulders chiefly found in and near the stream beds, where the water table is usually at a considerable depth below the surface. These possess little power of retaining water or of raising the subsoil water by capillarity to replace that lost at the surface by evaporation. They are liable to be excessively heated by solar radiation in the day and in the hot season and to be excessively cooled by terrestrial radiation at night and in the winter, especially where the free circulation of air is impeded.

III. Areas where the soil is characterised by containing a considerable admixture of clay, or humus, or both, and which varies from light to fairly stiff loam. These areas are to a considerable extent confined to the higher plateaus owing partly to the stiff soil offering resistance to erosion. They are as a rule well urained anc the soil therefore retains water well, while the water lost at the 
surface is readily replaced by capillarity. Both as regards supply of moisture, degree of soil aeration and temperature, thereforc, this type is intermediate between I and II.

39. The above types have, as a rule, been clearly distinguished by practical Forest Officers and, in Working-Plans, I and II are usually described under the name of the recent or low alluvium and III under the name of the old or high alluvium.

From the explanations given in paragraph 7 above it will be seen that II is a typically xerophytic and III a mesophytic locality. I is probably on the wholc mesophytic although for some types of vegetation it is hygrophytic.

The terms old and recent are apt to encourage the deduction that there has been in every case, as regards the œeological characteristics of the soil, what may be called a devclopmental, or progressive, succession of the same type and which has gradually resulted in the conversion of the recent, or low alluvium, into the old, or high, alluvium.

To a great extent this is probably true, but it is obvious that we must clearly distinguish two main types of succession, viz.:-

(1) That in which water-logged soil, usually containing a large admixture of clay, becomes converted into well-aerated moist loam by a lowering of the watertable and addition of humus.

(2) That in which dry sand becomes converted into moist loam chiefly through the addition of humus.

It is equally clear that we must recognise the possibility of a regressive succession, such as might arise for instance through the clearing of the forest growth and cutting off the supplies of humus.

Mr. Millward ${ }^{1}$ in an interesting paper has emphasized the fact that, according to their mode of deposition, in still or running water, soils differ $a b$ initio essentially in their quality and composition owing to the size of the constituent particles, on which the distinctions between gravel, sand, loam and clay depend. Consequently bare unoccupied areas of soil of the same age may become available for the first time for plant colonisation which may vary from practically pure clay to coarse gravel, and the fact that the heavy soil in this locality is now chiefly found on the higher slopes and plateaus is probably due to its having resisted erosion better than the light sandy soils.

It is important to realise these points, inasmuch as changes in the ocological characteristics of the soil are directly connected with the succession of different types of vegetation, and it has already been explained in the footnote to paragraph 14 above that, as regards the most important type of vegetation in the loc:lity here dealt with (viz. Sal forest), we 
must recognise not one, but several, possible modes of origin, differing according to the moisture content of the soil and to its initial sandy or clayey nature. dealt with, the details given below, which have been abstracted from the meteorological records of Dehra Dun station, give some idea of the prevailing conditions. Dehra Dun, as will be seen from the map, Plate $I$, is approximatcly in the centre of the Dehra Dun valley and it is situated at an elevation of 2,233 feet above mean sea level.

The area lying to the south of the Siwaliks rcceives less rainfall, averaging from 30 to 50 inches only per annum, and also possesses a more severe climate with a uniformly higher average shade maximum temperature throughout the year and with a lower average minimum shade temperature in December and January.

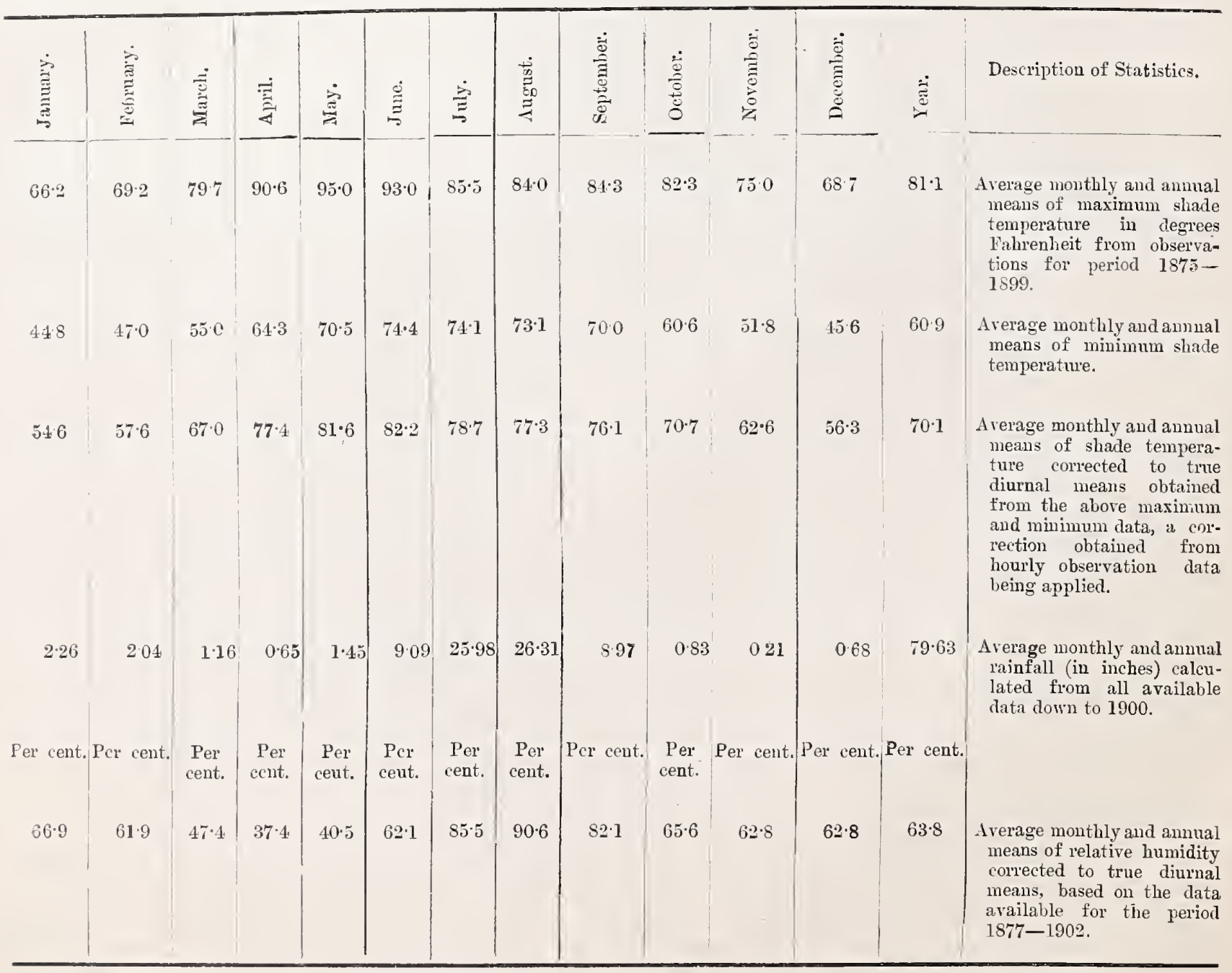

Thie highest absolnte maximum shade temperature recorded at Dehra Dun previous to 1903 is $111^{\circ}$ registered in June.

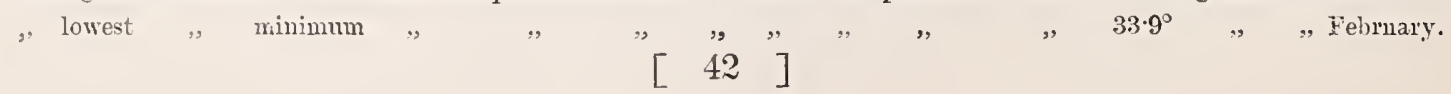


Of the greatest importance for vegetation also are the maximum temperatures recorded in the sun's rays and the minimum temperatures on the grass, regarding which no reliable figures are available for years subsequent to 1890 .

The following figures show the maximum temperature recorded in the sun each month during the three years 1888-90:-

Maximum reading in sun's rays by Black Bulb Thermometer.

\begin{tabular}{|c|c|c|c|c|c|c|c|c|c|c|c|c|}
\hline Year. & January. & February. & Jarch. & April. & May. & Junc. & July. & August. & September. & Oetober. & Sovember. & December. \\
\hline 1888 & $i 26^{\circ} .7$ & $132^{\circ} \cdot 5$ & $146^{\circ} \cdot 9$ & $153^{\circ} \cdot 5$ & $155^{\circ} \cdot 5$ & $161^{\circ} \cdot 0$ & $156^{\circ} \cdot 0$ & $155^{\circ} \cdot 4$ & $151^{\circ} \cdot 5$ & $142^{\circ} \cdot 1$ & $135^{\circ} \cdot 9$ & $126^{\circ} \cdot 0$ \\
\hline 1889 & $131 \cdot 5$ & $133 \cdot 5$ & $144 \cdot 4$ & $155 \cdot 3$ & $159 \cdot 0$ & $157 \cdot 3$ & $158 \cdot 7$ & $157 \cdot 0$ & $154 \cdot 0$ & $142 \cdot 9$ & $136 \cdot 0$ & $129 \cdot 1$ \\
\hline 1890 & $132 \cdot \mathrm{S}$ & $136 \cdot 4$ & $143 \cdot 5$ & $157 \cdot 8$ & $157 \cdot 5$ & $155 \cdot 3$ & $159 \cdot 6$ & $152 \cdot 8$ & $151 \cdot 2$ & $143 \cdot 6$ & $132 \cdot 6$ & $130 \cdot 6$ \\
\hline Mean & $130 \cdot 3$ & $134 \cdot 1$ & $144 \cdot 9$ & $155 \cdot 5$ & $137 \cdot 3$ & $157 \cdot 9$ & $158 \cdot 1$ & $155 \cdot 1$ & $152 \cdot 2$ & $142 \cdot 9$ & $134 \cdot \mathrm{s}$ & $125 \cdot 6$ \\
\hline
\end{tabular}

The highest temperature recorded being $161^{\circ}$ registered in June 1888. These figures indicate the temperature which may be reached in grasslands surrounded by forest where there is little or no circulation of air.

The following figures show the minimum temperatures recorded on the grass for the same period, as recorded at Dehra Meteorological Station :-

Minimum reading on grass taken at 9-30 A.M.

\begin{tabular}{|c|c|c|c|c|c|c|c|c|c|c|c|c|}
\hline Year. & Janaary. & February. & March. & April. & May. & June. & Juls. & Angust. & Septenber. & October. & Norember. & December. \\
\hline 1888 & $31^{\circ} \cdot 2$ & $36^{\circ} \cdot 2$ & $47^{\circ} \cdot 2$ & $46^{\circ} \cdot 1$ & $55^{\circ} \cdot 2$ & $63^{\circ} \cdot 0$ & $68^{\circ} \cdot 6$ & $67^{\circ} \cdot 0$ & $61^{\circ} \cdot 3$ & $47^{\circ} \cdot 3$ & $39^{\circ} \cdot 7$ & $35^{\circ} \cdot 4$ \\
\hline 1889 & $35 \cdot 0$ & $30 \cdot 3$ & $43 \cdot 8$ & $49 \cdot 3$ & $58 \cdot 0$ & $66 \cdot 9$ & $68 \cdot 1$ & $68 \cdot 8$ & $56 \cdot 4$ & $47 \cdot 2$ & $38 \cdot 9$ & $32 \cdot 4$ \\
\hline 1890 & $32 \cdot 1$ & $34 \cdot 7$ & $43 \cdot 8$ & $50 \cdot 2$ & $59 \cdot 8$ & $65 \cdot 4$ & $69 \cdot 7$ & $66 \cdot 5$ & $59 \cdot 4$ & $47 \cdot 9$ & $40 \cdot 3$ & $37 \cdot 1$ \\
\hline Mean & $32 \cdot 8$ & $33 \cdot 7$ & $44 \cdot 8$ & 48.5 & $57 \cdot 7$ & $65 \cdot 1$ & $68 \cdot 8$ & $67 \cdot 4$ & $59 \cdot 0$ & $47 \cdot 5$ & $39 \cdot 6$ & $35 \cdot 0$ \\
\hline
\end{tabular}

In many of the forest grasslands of the locality, however, considerably lower temperatures are undoubtedly reached than those recorded at Dehra Dun Station. Frost is frequently observed in these grasslands during December and January and is in many cases the principal factor responsible for the absence of tree growth.

The period of maximum vegetative activity for most of the grasses dealt with in this paper is, as might have been expected, the rainy season from June to September. ${ }^{1}$

It is remarkable, however, that almost all these species show a certain degree of activity throughout the year, with the exception of the months December-January. In these

In the crse of one sl ecies, Imperata arundinacea, it is remarkable that maximum growth usully takes place in the period March-May. 
ruonths a general cessation of activity is more or less marked and is apparently caused mainly by the low temperature.

As regards an explanation of the periodicity shown by the various species it is highly desirable that statistics should be obtained showing, for the different classes of soil, the actual average water-content of the surface layers of bare unworked soil monthly throughout the year and especially during the period October to May inclusive. Such statistics would indicate the net result of the opposing factors of, on the one hand, rainfall, dew deposition and the raising of the subsoil water by capillarity, and on the other hand of loss through percolation and evaporation at the surface, and this net content is of extreme importance for vegetation.

Unfortunately no statistics of this nature appear to be at present available in India, but observations on this point will now be made at Dehra Dun in connection with the study of the cecology of Sal.

A point which has been frequently noticed in connection with several of the species dealt with in this paper is that, in areas where the grass has been cut or burnt, vegetative activity commences earljer than it would otherwise have done and the growth of the young shoots is far more vigorous, especially during the period February to May, than in areas which have not been cut or burnt. Forest Officers are well acquainted with this phenomenon and know that areas burnt in the cold season are covered with a good crop of green grass in the ensuing hot weather, when there are few or no green shoots to be seen in protected areas. The clearing away of the old grass and dead leaves by fire enables the dew and rainfall to at once penetrate the soil instead of being obstructed by, and evaporated from, the old grass, and thus prevented from finding its way into the soil and becoming available for the grass roots, while it also removes the injurious shade which to a considerable extent retards the development of the young shoots.

Locel Types of Vegeta.

tion.
41. In the area considered in this paper examples of almost all the main types of vegetation mentioned in paragraph 26 above, both of grassland and of woodland, are to be found.

Hygrophilous grassland is represented by well-developed reed-swamp communities of Phragmites and Arundo and perhaps also by the wet Savannah Erianthus, while a type of woodland which should possibly be ranked as intermediate between mesophilous and hygrophilous is represented by some remarkable swamp forests containing such species as-Carallia lucida.

Cyclostemon assamicus.

Bischofia javanica.

Calamus tenuis.
\} Of the Indian Evergreen Forest tracts.

As well as such temperate species as Quercus incana, Acer oblongum and Hedera Helix.

These swamp areas however are of comparatively limited extent and are not dealt with in this paper. 
The most important and widely distributed types of grassland in this locality which it is proposed to consider in detail are briefly defined in the accompanying statement which also indicates the corresponding type of woodland :-

\begin{tabular}{|c|c|c|c|c|}
\hline \multirow{2}{*}{ Serial Yo, } & \multicolumn{2}{|r|}{ GRAKELAND. } & \multicolumn{2}{|r|}{ WOODLAXD } \\
\hline & Type of Vegetation, & Description of Community. & Type of Vegetation. & De seription of Comnunuts. \\
\hline I & $\left\{\begin{array}{l}\text { Xeropbilous } \\
\text { Steppe. }\end{array}\right.$ & $\begin{array}{l}\text { Andropogon monticola. } \\
\text { Aristida cyanantba } \\
\text { Tririphis madagascariensis } \\
\text { saccharum spontaneum (xerophilous } \\
\text { form). } \\
\text { Saccharum Nunja (xerophilous } \\
\text { form). }\end{array}$ & $\left\{\begin{array}{l}\text { Xerophilous } \\
\text { Miscellaneous } \\
\text { Forest. }\end{array}\right.$ & $\begin{array}{l}\text { Calotropis procera. } \\
\text { Orthanthera viminea. } \\
\text { Zizyphus. Jujuba. } \\
\text { Adhatoda Vasica. } \\
\text { Acacia eburnea. } \\
\text { Acacia Catechu. } \\
\text { Dalbergia Sissoo. }\end{array}$ \\
\hline II & $\left\{\begin{array}{l}\text { Mesophilous } \\
\text { Moist } \\
\text { Savannah. }\end{array}\right.$ & Saccharum Iunja dominant & $\begin{array}{l}\text { Mesophilous } \\
\text { Dry Miscella- } \\
\text { neous } \\
\text { Forest. }\end{array}$ & $\begin{array}{l}\text { Zizyphus Jujuba. } \\
\text { Adhatoda Vasica. } \\
\text { Acacia Catechu. } \\
\text { Dalbergia Sissoo. } \\
\text { Bombax malabaricum. } \\
\text { Gitruga pinnata. } \\
\text { Odina Wodier. } \\
\text { Phyllanthus Emblica. } \\
\text { Egle Marmelos. } \\
\text { Zizyphus xylopyra. } \\
\text { Grewia oppositifolia. } \\
\text { Moringa pterygosperma, } \\
\text { Bauhinia racemosa. } \\
\text { Murraya Koenigii. } \\
\text { Holarrhena antidysenterica. } \\
\text { Kydia calycina. } \\
\text { Ehretia lævis. }\end{array}$ \\
\hline III & $\begin{array}{l}\text { Mesophilous } \\
\text { Moist } \\
\text { Savannah. }\end{array}$ & Saccharum Narenga dominant & $\begin{array}{l}\text { Mesophilous } \\
\text { Sal Forest. }\end{array}$ & Shorea robusta dominant. \\
\hline IV & $\left.\begin{array}{l}\text { Mesophilous } \\
\text { or perhaps } \\
\text { Hygrophilous } \\
\text { Wet } \\
\text { Savannah. }\end{array}\right\}$ & Erianthus Ravennæ dominant & $\begin{array}{l}\text { Mesophilous } \\
\text { Moist Miscel- } \\
\text { laneous } \\
\text { Forest. }\end{array}$ & $\begin{array}{l}\text { Dalbergia Sissoo. } \\
\text { Garuga pinnata. } \\
\text { Holarrhena antidysenterica. } \\
\text { Kydia calycina. } \\
\text { Ehretia lævis. } \\
\text { Grewia elastica. } \\
\text { Bridelia retusa. } \\
\text { Butea frondosa. } \\
\text { Stereospermum suaveolezs. } \\
\text { Bombax malabaricnm. } \\
\text { Vallotus philippinensis. } \\
\text { Anogeissus latifo:ia. } \\
\text { Adina cordifolia. } \\
\text { Terminalia tomentosa. } \\
\text { Terminalia belerica. } \\
\text { 'Terminalia Chebula. } \\
\text { Gmelina arborea. } \\
\text { Eugenia Jambolana. } \\
\text { Cordia Myxa. } \\
\text { Cedrela Toona. } \\
\text { Celtis australis. } \\
\text { Tremia nudiflora. }\end{array}$ \\
\hline
\end{tabular}


For the reasons noted in paragraph 39 above it is perhaps inadvisable to employ the terms "old" and " recent alluvium " but Vegetative type III may be said to occur chiefly on what is often known as the high alluvium and Nos. I, II and IV mainly on the low alluvium. Considering the parallel grassland and woodland together as a compound community the above communities may be more briefly defined as below where are also approximately indicated the conditions of soil and moisture, which, in the climate of this locality, enable the various species to here exist together and to form more or less clearly defined communities.

\begin{tabular}{|c|c|}
\hline Community. & Soil and moisture characteristics of Habitat. \\
\hline I. Aristida-Acacia . & $\begin{array}{l}\text { The soil is very dry ; it consists chiefly of gravel and stones and } \\
\text { has very little capacity for retaining moisture or for raising } \\
\text { it by capillarity. }\end{array}$ \\
\hline II. Saccharum-Dalbergia-Bombax & $\begin{array}{l}\text { The soil differs from that of No. I in containing a greater } \\
\text { proportion of small particles and is therefore more sandy but } \\
\text { it is still essentially dry. }\end{array}$ \\
\hline IJI. Saccharum-Shorea & $\begin{array}{l}\text { The soil is distinctly loamy and moist, but well aerated and is } \\
\text { usually characterised by a more or less considerable ad- } \\
\text { mixture of humus. }\end{array}$ \\
\hline IV. Eriauthus-Mallotus-Terminalia & $\begin{array}{l}\text { The soil is moist to wet, less aerated than that of No. III and } \\
\text { with a more or less considerable admixture of clay. Owing } \\
\text { to the large proportion of clay this soil is apt to become } \\
\text { slightly water-logged in the rains and also to suffer from } \\
\text { drought after the rains, owing to the capillary movements } \\
\text { of water being very sluggish. }\end{array}$ \\
\hline
\end{tabular}

that there is no sharp line of distinction between the above communities and just as the factors of the locality, such as the character of the soil, extent of soil aeration, quantity of soil moisture, etc., frequently change very gradually and vary very slightly from place to place, we get habitats with intermediate characteristics and more or less intermediate minor communities connecting the main types.

Thus considering grassland first, the coarse shingle and gravel thrown up by the most rapidly running currents provide a habitat for the typical desert, or steppe, community composed chiefly of Aristida, with often scattered tufts of Andropogon monticola. As the proportion of small particles increases in the deposits left by less rapidly flowing water, and the soil becomes more sandy, the following species appear; the narrow leaved most xerophilous form of Saccharum spontaneum, Triraphis, and the narrow leaved, more or less stunted, most xerophilous form of Sacharum Munja, while Andropogon monticola becomes more vigorous and numerous. As the proportion of sand increases and the capacity of the soil for retaining more moisture and raising it from the water-table by capillarity 
slightly increases, owing to a small admixture of clayey particles, or organic humus, Saccharum. Munja becomes the dominant species. While intermediates between these two communities thus occur, there is a marked dominance of Aristida on the very dry coarsegrained soil and of Saccharum on the relatively moist and fine-grained soil. Similarly in the Saccharum Munju savannah, in places where the soil is distinctly wet, usually on account of a considerable increase in the proportion of clay, Erianthus appears and gradually connects the moist with the wet savannah. Eriunthus, while approaching swamp very closely, does not itself actually enter into the typical swamp community found on perennially water-logged soil, but Saccharum spontaneum var. nepalense and Imperata arundinacea var. latifolia both find a congenial habitat in the soft, spongy, perennially thoroughly saturated soil of the marsh; other forms of both these species are found in the moist savannah, and Saccharum spontaneum also occurs in the steppe.

The Saccharum Narenga savannah is usually a very well marked type, but here also small areas may occasionally be found where this species occurs in company with Saccharum IUnja and also with Erianthus Ravennce. Such an admixture is usually brought about in nature as the result of a regressive change in the soil. When sal forest on light loamy soil, for instance, is felled, provided the area is sufficiently large, the proportion of humus, and consequently the capacity of the soil for retaining water, rapidly decreases, while the soil also becomes dried by exposure to the sun and air currents. In such conditions Saccharum IIunja and Saccharum Narenga may be found together, the former eventually becoming dominant and ousting the latter, if frost or other factors prevent the re-establishment of woodland.

Similarly if moist, mixed forest on heavy soil (especially if it contains a considerable admixture of Sal) is felled, the resulting decrease in humus content tends to make the soil denser and thus less porous, while the rapid movement of water by capillary action is checked. The soil thus tends to become less aerated and more liable to become somewhat water-logged during the rainy season.

In such conditions both Saccharum Narenga and Erianthus Ravennce may coexist for a time and these species may thus be found together. If the cleared area is extensive, however, the drying action of sun and wind soon makes the habitat too dry for Erianthus and it may be replaced by the moist savannah form of Imperata and Saccharum spontaneum and by less strongly mesophilous species of Andropogon and Pollinia.

In dealing with this question of intermediate forms, also, it must be remembered that, in addition to the very gradual changes in the intensity of the factors of the locality, we must allow for the undoubted fact that the constitution and adaptations of a particular species frequently enable it to thrive in essentially different habitats and to enter into the constitution of essentially different communities. Thus Saccharum spontaneum enters into the composition of the steppe-A ristida community, it forms a part of a typical reedswamp community, and finally may be often found in mesophilous grasslands.

Similarly Imperata arundinacea is found locally in both moist and wet savannah. usually on heavy clay, which is liable to become water-logged during rain and to become 
rapidly dried after rain owing to poor capillary action, the oxygen content being apparently too small for Saccharum Munja and the water content too small for Erianthus Ravennce, these species therefore being unable to oust the less vigorous plant. On the other hand Imperata is able to thrive and attains its maximum dimensions in a typical swamp, where neither of the larger species can penetrate.

This has already been alluded to in paragraph 22 above, where attention was drawn to the fact that one and the same species may frequently be found to thrive well on a physically dry soil, such as a sand or dense clay, and also on a physiologically dry soil, such as the saturated, water-logged soil of a marsh. Notwithstanding the fact then that intermediate forms occur, partly on account of the gradual shading away of the environmental factors and partly on account of the fact that one and the same species may occur in different habitats and communities, field workers will, it is believed, readily admit that the four main types of grassland indicated above can be easily distinguished and that they are separated by real differences, both as regards the conditions of the habitat and the characteristics of the vegetation. munities, the Forest Officer will, it is believed, readily admit the importance of selecting and describing types, even though these be connected more or less completely by intermediate forms. Thus, although four of the seven species given for community No. I are commonly found also in No. II, there is a real difference between the open crop of No. I with more or less isolated clumps of Zizyphus, Adhatoda, Acacia and Dalbergia, with bare spaces occupied by the shrubs Calotropis and Orthanthera and with scattered tufts of xerophilous grasses, on the one hand, and the more or less close crop of the dry miscellaneous forest forming type No. II on the other hand, in which a number of additional species have appeared.

Similarly there is an undoubted difference between Nos. II and IV although many of the species found in the former also pass into the latter. In IV, however, there is an obvious preponderance of species which require a larger quantity of available moisture and which are not found in No. II.

Again, although many of the species characteristic of No. IV occur also associated with Sal, there is no difficulty in distinguishing No. III in which the Sal is always the dominant species as a distinct type. Just as in the case of grassland, so here also we have species like Bombax malabaricum and Garuga pinnata which grow well in physically dry soil and also in heavy wet soils and species like Egle Marmelos which thrive on dry sandy soil and also on hard clay.

The Forest Officer has long recognised this fact that certain species occur in very different liabitats in distinguishing what he calls indicating species, or indicators, which are, as a rule, only found in places where a particular soil occurs, where a certain quantity of moisture is available, or where a particular intensity of light prevails, and which thus indicate the existence of certain factors and their intensity, from those termed indifferent 
species, which give no such indication. At the same time probably no plant community consists entirely of indicators, considering the term in the present narrow sense, and hence in our descriptions of communities we must record the constituent species as we find them, whether they be indicators or indifferent.

Moreover it is only by studying these so-called indifferent species in their various habitats that we get a correct idea of the conditions necessary foi their development.

Plates II-XII inclusive will give an idea of the physiognomy of the various communities of grassland and woodland which have been briefly indicated above.

44. As regards furnishing a complete explanation as to why each of the individual species mentioned is. in nature, able to form a constituent part of the various communities indicated above, under the conditions ruling in this locality, it is perhaps hardly necessary to point out that this will only become possible when the œcology of each individual species has been thoroughly worked out in detail, and this has not yet been done. 
C H A P T E R I I.

(i) Detailed Description of Species.

Saccharum spontaneum, Linn. (Plates III and XIII.-XVIII.)

Refercuces.

Distribution.

$$
\begin{aligned}
& \text { F. B. I., VII, } 118 . \\
& \text { P., II, } 1188 .
\end{aligned}
$$

H., 113.

C., II, 948

India, Afghanistan, Burma, Ceylon, Arabia, Syria, Africa, China, Java, Philippines, New Guinea, Australia.

Vernaculat Name. culm.

Leaf-sheath.

Kāns, kānsi.

\section{A.-Description.}

Erect or decumbent at base. Has been measured locally $14^{\prime} 2^{\prime \prime}$ (excluding prostrate or subterranean portion) long but is said to attain $20^{\prime}$ (fide F. B. I.).

On dry sand very slender often not exceeding $0 \cdot 10 \mathrm{in}$. diameter, but in favourable localities attaining a diameter of $0.6 \mathrm{in}$. Solid above, fistular below, terete, indistinctly striate.

Usually pruinose when young, polished when old.

Silky below the paricle and minutely silky below the upper leaf insertions.

Glabrous or minutely pubescent below the lower leaf insertions.

Longer than proper internode, often with reddish or purplish blotches.

Villous at mouth, often minutely pubescent at base, otherwise glabrous or with scattered adpressed hairs, sulcate.

Lamina. in length.

Erect. Of upperinost leaf of flowering culm usually long, but varying from $2^{\prime \prime}$ to $3^{\prime}$

Of lower leaves, attains a length of $4^{\prime}$ (Roxburgh gives $7^{\prime}$ ).

Usually very narrow, frequently not exceeding $0.05^{\prime \prime}$ in width and then consisting of a very narrowly margined concavo-convex mid-rib, but attains a width of $0 \cdot 7$ in. Greatest width about the middle.

Colour glaucous, mid-rib white.

Apex long acuminate, base narrow consisting of the mid-rib

Margin scabrid.

Often villous above at base immediately behind the ligule.

Ligule.

Ovate to deltoid, base often sub-auricled.

Membranous, sub-acute or sub-truncate, often fimbriate when old.

Up tc 0.25 in. high. Minutely silky dorsally and ciliate.

Spikelets in pairs, one pedicelled and one sessile on the capillary jointed branches and branchlets of a terminal panicle. 
Primary rachis sulcate, silky with long white hairs,

Primary branches sub-verticillate, simple or compound.

Flowcring panicla $6 "-2$ feet long', conical or lanceolate to oblong, branches horizontally spreading, or slightly ascending, usually reddish or purplish in colour, with the callus hairs closely adpressed to the panicle branches.

Fruiting panicle is woolly and silvery white with the long wide-spreading white callus hairs and the panicle branches are erect or ascending.

The horizontally-spreading callus hairs of the fruiting spikelet forms an efficicnt parachute which aids its distribution by wind. The hairs of neighbouring spikelcts becoming entangled together, characteristic flocculent masses of several spikelets are often seen being carried by the wind or hanging on the adjacent vegetation.

Awnless, lanceolate, $0 \cdot 08$ to $0 \cdot 2$ in. long.

Spikelets.

Sessile and pedicelled similar, each one-flowered and ș.

Pedicelled fruiting spikelet falling from the pedicel, the sessile spikelet falling later with the attached pedicel and joint of axis.

Joint of axis longer or shorter than sessile spikelet, villous on margins, or on margins and dorsally.

Pedicel $\frac{1}{4}$ to $1 \frac{1}{4}$ sessile spikelet (but usually shorter than spikelet), glabrous or ciliate, shorter than proper joint. ${ }^{1}$

Callus hairs white from $1 \frac{1}{2}$ to 7 times as long as sessile spikelet.

Lanceolate, the basal third thickened becoming hard and polished in fruit and more Glume I. or less brown in colour, the upper two-thirds membranous hyaline. With two lateral nerves from which the margin is inflexed. Apex entire or minutely bi-dentate. Margin ciliate; dorsally with the upper two-thirds minutely adpressed-pubescent.

Broad-lanceolate, similar to I, but sub-keelcd with one central nerve.

Glume 11 .

Apex sometimes mucronate.

Margin inflexed and long ciliate.

Hyaline, nerveless, shorter than II, ovate-lanceolate, long ciliate, minutely pubescent alume III. above dorsally.

Hyaline, minute, linear, ciliate, sometimes absent. In all fresh flowering specimens Glume $\boldsymbol{I}$. examined this glume has been found, in dry fruiting specimens the dissection of the inner parts of the spikelet is somervhat difficult and it is possible that this glume is sometimes overlooked.

Ovate, minute, ciliate, often shorter than the lodicules.

Two, cuneate, glabrous or apex ciliate.

Three, yellow, turning brown, 0.06 to 0.09 in. long.

Lodieules.

Two, purple, 0.05 in. long.

Anther's.

Stigmas.

\footnotetext{
${ }^{1}$ Proper joint $=$ joint to which the pedicel in question is attached.
} 
The narrow leaves and slender culms, the long callus hairs and the brown coriaceous base of glumes I and II are good field characters.

\section{B.-TAxonomy.}

45. Hackel ' classifies the Indian forms of this species under two sub-species which he defines as follows :-

Sub-species a. indicum.-Slender. Culm 3-4 mm. in diameter. Lamina narrow linear (2-6 mm. wide). Ligule ovate, sub-acute, oftcn sub-auricled at base. Racemes slender, few-flowered. Spikelets 3-4 mm。 long, callus-hairs white, very soft, 4-6 times longer than spikelets.

Sub-species b. cegyptiacum.-Robust. Culm 4-6 mm. in diameter. Lamina broad linear (6--14 mm. wide). Ligule truncate. Racemes stout, densely flowered. Spikelets 4-6 mm. long, callus-hairs twice as long as spikelets (or a little more)

The only Indian form placed by Hackel under cegyptiacum is the variety nepalense whick he describes as having leaves up to 6--10 mm. wide, a linear-oblong panicle, spikelets $4 \mathrm{~mm}$. long and callus-hairs somewhat stiff, white, $2 \frac{1}{2}$ times longer than the spikelets.

The present species varies greatly according to its habitat, as will be seen from the biological and œcological notes given below, and in India the thrce following œecological forms can be distinguished in the field although, connected as they are by numerous intermediate forms, their separate definition under different names as sub-species or varieties does not seem advisable :-

(1) The most xerophilous form found on dry sandy soil. Culms slender, usually less than 0.2 " in diameter, erect and tufted. Leaves exceedingly narrow, sometimes only 0.05 " wide, callus-hairs not less than $3 \frac{1}{2}$ times the spikelet. This may for the present be distinguished as the sand-form.

(2) The most hygrophilous form found in swamps and marshes where there is an abundance of available moisture more or less throughout the year. Culms stout, $0 \cdot 2^{\prime \prime}$ to $0 \cdot 6^{\prime \prime}$ in diameter, usually decumbent at base and not tufted, leaves broad attaining a width of $0 \cdot 7^{\prime \prime}$, callus-hairs $1 \frac{1}{2}-3 \frac{1}{2}$ times as long as spikelets.

The fruiting paniclc is elongate-elliptic to oblong with its branches usually more persistent than in other forms.

This includes the var. nenalense of Hackel and may be distinguished as the swamp-form.

(3) A form intermediate between (1) and (2), usually found on loam, with culms more or less decumbent at base and not tufted, but less robust and with longer callus-hairs than (2). This may be called the loam-form. 
Whatever characters are taken, however, whether the habit of growth, dimensions of culns, width of leaves, length of spikelets, or of the callus-hairs, numcrous intermediates connecting the above forms can be found and obscrvations in the field indicate that the characters in question vary directly according to the quality and stability of the soil, liability to the "laying" action of wind and water, and the quantity of available moisture in the habitat.

Plants of the above three forms of this species arc now being cultivated in the Dehra Dun Experimental Garden with the object of testing the effect of soil and varying quantities of available moisture on the characteristics of the plants. Some tufted plants taken from dry sand and planted in loam have already, in a single growing season, produced some widespreading robust culms which rescmble those of the decumbent loam-form.

The African forms placed by Hackel under his sub-species agyptiacum, varicty agyptiacum, differ from the Indian plants examined by the writer chiefly by their slightlv larger spikelets. This difference however is very slight and fails in the case of some African specimens. Considering the great variability af the species in India it seems possible that a more complete knowledge of the African plant will prove agyptiacum to be merely one of several œecological forms which are defined by inconstant characters and which are connected by numerous intermediates. ${ }^{1}$

Hackel himself notes that intermediates do occur between his sub-species indicum and cogyptiacum (l.c., p. 116).

Roxburgh's species Saccharum spontaneum, S. semidecumbens and S. canaliculatum ${ }^{2}$ are undoubtedly all referable to the single species described as $S$. spontaneum in this papcr. It is however important to note that in his descriptions of all these three plants Roxburgh states that the corol is one-valved. Now glume IV is frequently present in this species, although as a rule it is minute and very narrow, while the pale is also present, although the latter is minute and often shorter than the lodicules. Hence when Roxburgh speaks of a "one-valved corol" in his descriptions it must not be assumed that glume IV and the pale are absent, but rather that these parts are small and inconspicuous. This is important, since Hackel (l.c., p. 119) rojects Roxburgh's name of Saccharum IIunja on the ground that the description of that species as having a "two-valved corol "necessarily implies the absence of the pale.

Roxburgh's Saccharum exaltatum is a doubtful plant. The sheet from Roxburgh's collection representing this species in the Herbarium of the British Museum is only named in pencil and is believed to have been named by Solander. The plant on this sheet is undoubtedly that described as Saccharum IIunju in this paper.

1 The view taken in this paper regarding the limitation and definition of plaut groups in descriptive botany is that it is neither advis. able on the one hand to combins together distinct species or sub.species between which only isolated interinediates of probably hybrid origin exist and which can therefore be distinguished in the field as listiuct grouns, nor, on the other hani, to separately describe and name groups which are defined by inconstant characters varying with the cological factors of the habitat (arailable moisture, soil, light, temperature, etc.) and which are comected in the field by numerous intermediates. Groups of the latter description can be sufficicutly indicated perature, etc.) and which are comected in the ticld by numerorm, sas swamp-form, sand-form, shade-form,

${ }^{2}$ Flora Indica, Ld. Carcy, 1\$32, Vol. I, pp. 235, 236, 246. 
Hackel refers this species of Roxburgh doubtfully to Saccharum arundinaceum Retz. It is possible that Roxburgh's remark in his description of this species "compare with Saccharum arundinaceum" (l.c., p. 245) is to some extent responsible for this identification. It is not clear what Roxburgh meant by this, for there is no doubt that the Saccharum arundinaceum of Retz is the Saccharum procerum of Roxburgh. The unpublished plate of Saccharum exaltatum, while clearly showing that Roxburgh's plant is not Saccharum arundinaceum, is a very fair representation of Saccharum. Narenga with which the culm, leaf, narrow brownish panicle, length of joints of panicle branches, the brown colour of glumes I and II and other characters agree well.

On the other hand the plant figured in Rhede's Hortus malabaricus, XII, t. 46, is almost certainly Saccharum spontaneum and Roxburgh himself considers Rhede's plant to be probably his Saccharum exaltatum (l.c., p. 245).

Against this identification with Saccharum spontaneum however is the fact that glumes I and II of Saccharum exaltatum are described and drawn as "covered with much long, eream-coloured soft hair "(l.c., p. 245). Roxburgh's description "root-creeping" while applying to forms of both Saccharum spontaneum and Saccharum Narenga does not apply to either Saccharum arundinaceum or Saccharum Munja. On the whole therefore it seems probable that Saccharum exaltatum Roxb. = Saccharum Narenga Wall. although it is remarkable that Roxburgh makes no mention of the bearded leaf-insertions and hirsute leaf-sheaths. It must however be remembered that the hairs on the slieaths of this species are deciduous.

\section{C.-Biological and (Ėcological Notes}

Habitat.

46. This is on the whole the most xerophilous species of Saccharum dealt with in this paper, a fact which is indicated by its exceedingly narrow, hard and glaucous leaves. It is often found on dry sand associated with Triraphis, Andropogon monticola and stunted Saccharum Munja.

At the same time it is not sensitive as regards soil-aeration and like Imperata it can thrive on stiff clay, while its maximum dimensions are attained (by variety nepalense) in the water-logged soil of the marsh.

Its occurrence indicates that it requires even less moisture than Imperata.

It is frequently seen on loam which is too dry for a vigorous development of Imperata, or which is too dry or too water-logged for Saccharum Munja, S. Narenga or Erianthus Ravenno and it is there often associated with Vetiveria zizanioides Stapf (=Andropogon squarrosus).

It has some capacity for standing shade and culms produced in the shade of trees and shrubs show exceptional length and have been measured in this locality up to 12 feet 8 . inches. 
47. This plant is perennial and usually pevelopment gregarious. The culms originate from the basal nodes of older culms either above or below Seasen of the ground surfaee. A culm which originates below the ground surface may either at once setivity and assume an ereet habit of growth, in which case the young culms arise in the immediate neighbourhood of the older eulms and a more or less clearly defined tuft or clump results, or else the young culm may grow for some time in a horizontal or oblique direction below the fround surface, before its apex eventually turns upwards and assumes an erect habit of growth. In the iatter ease the eulms are widely scattered and no tuft or clump is found. In this respeet this species differs from the other speeies of Saccharum and Erianthus dealt with in this paper in which each culm at first only grows outwards in a more or less horizontal direction at the base for a very short and constant distanee before eventually turning upwards and beeoming erect and in which a new bud at once arises and eontinues this horizontal growth, as the older eulm beeomes erect. In these speeies therefore the growth resembles that of a typical rhizome, whereas in $S$. spontaneum there is no well-defined rhizome.

In the other speeies of Saccharum and Erianthus dealt with, also, the culms usually arise elose together and form well-marked clumps. In $S$. Narenga, however, a tendency towards a spreading habit and the eonsequent produetion of ill-defined elumps is sometimes seen.

The present species in this locality is often found on sand in and near the beds of water-courses and in sueh places the plant is liable to be eovered by masses of sand and débris brought down by floods. It is only under these eonditions that the tufted habit prevails and this appears to be an obvious adaptation which facilitates the rapid produetion of aerial eulms from the ground surfaee and prevents the plant being overwhelmed and smothered by aceumulations of débris and sand. In relatively stable soil, such as the loamy soii of eultivated areas, the spreading habit prevails and enables the plant to extend anc occupy large areas far more rapidly than would be possible with the tufted habit of growth.

In plaees where the plant is directly exposed to the rush of a water current, the spreading habit is also eommon and this is to a great extent caused by the young eulms being "laid" by the meehanieal aetion of the water, just as are often eereals by heavy wind. Culms whieh are thus laid prostrate are often eovered more or less deeply with sand and root at the nodes and they then look exactly like the ordinary subterranean rhizome branehes. The more luxuriant the growth, the taller and larger the eulms and the larger the leaves. the more liable is the plant to be laid in this way.

The luxuriant form of the species (which has been named nepalense by some botanists), therefore, which is often found in or elose to the beds of streams is particularly liable to this aetion and eonsiderable areas have been seen where all the culms of this plant have been laid perfectly flat and more or less eovered with sand. There is little doubt therefore that. the spreading habit exhibited by this form is to a great extent caused in this way.

$$
\text { [ } 55 \text { [ }]
$$


The xerophilous form of the species, on the other hand, which shows much inferior height growth, very slender, stiff and almost wire-like culms and very narrow leaves, as a. rule resists the laying action of water well. At the same time isolated culms of this form have been seen laid by water and rooting to a distance of $2-4$ feet from the parent plant.

The above remarks on habit may be summarised as follows :-

(1) The species shows a markedly rerophilous form frequent on dry sand, a hygrophilous form where an abundance of water is available and a form intermediate between these two which is common on agricultural lands, wet pastures, etc.

(2) The xerophilous form which often occurs on the dry sand deposits brought down by torrents in the rains, is liable to be covered by accumulations of water-borne (and possibly to some extent wind-carried) sand and débris, and it usually shows a marked tufted habit which is advantageous in enabling the plant to avoid being smothered. The stiff slender culms and small very narrow leaves of this form enable it to resist the mechanical action of wind and water and it is rarely "laid" in consequence. See Plate XIV.

(3) The intermediate form, common on agricultural lands and usually on loam, with a more or less constant surface level, shows a spreading habit which enables the plant to rapidly extend and occupy large areas. See Plate XIII.

(4) The hygrophilous form also shows a spreading habit and this is to some extent at least caused by its liability to be "laid" by water currents and possibly also to some extent by wind. See Plates III and XV.

Immature leafy culms of this species were cut over in the Dehra Dun garden and the effect of the cutting on their growth carefully watched. The cutting was done in such a way as not to injure the apical bud of the culm itself but to more or less destroy the green leaves existing on the culm when the cutting was done. The first thing noticed was that the destruction of the green leaves resulted in greatly diminishing the length of the internodes of the culm. See Plate XVIII, figs. 7 and 8. A series of abnormally short internodes preceded and succeeded by normal long internodes are frequently seen in the culms of this and other species and these, as a rule, indicate that the leaves of such culms have been more or less destroyed by the grazing of cattle, grass-cutting, or fire.

In order to study the susceptibility of any grass to fire-damage at any particular season it is obviously necessary to be acquainted with the life-history of the culms and to know what their usual state of development would be at that season. The development of the culms cannot be always satisfactorily studied in the Experimental Garden, as it often tends to there become more or less abnormal. Direct observation in the forest throughout the year is often not practicable and is in any case tedious. If, therefore, a method could be discovered by which the age of a culm could be approximately calculated at sight, and if its rate of development were known, it is obvious that a single observation would enable us 
to determine its size and state of development in any previous month (provided that growth had been continuous) and this would greatly facilitate the inquiry.

The culms of most grasses are annual and if such an annual culm is examined it will, as a rule, exhibit two or more very short internodes at the extreme basc which can be clearly distinguished from the subsequent much longer internodes. In other words such a culm exhibits more or less distinctly two periods of growth-

(a) a preparatory period of slow growth;

(b) a subsequent period of vigorous growth.

The short internodes produced during the preparatory period carry only scales, or else small and obviously under-sized leares. The internodes produced during the period of vigorous growth, on the other hand, carry well-developed green leaves. These internodes are also, as a rule, much longer than those of the preparatory period, but in some cases (especially in species like Saccharum Munja, the culms of which are bicnnial) several of them remain as short as those of the preparatory stage. A culm in the preparatory stage of growth is obviously merely a bud which possesses as yet no well-developed leaves and for practical purposes the life-cycle of a culm may be considered to commence with the period of vigorous growth, i.e., with the first production of well-developed leaves which is often (but not always) correlated also with the first production of long internodes and the commencement of a marked increase in length.

As regards the development of the culm during the period of vigorous growth, observations made at Dehra Dun on the sand-form of Saccharum spontaneum showed that in this plant, in this locality :-

(1) The period of development of an internode carrying a well-developed leaf at its apex approximately commences with the first appearance of the leaf at its apex and terminates with the complete withering of that leaf (including the sheath). This period can therefore be determined by noting respectively the date of appearance and of the withering of the leaf at its apex. In this species the period observed was five months. In one month therefore one internode with the leaf at its apex completes $\frac{1}{5}$ th of its life-cycle.

(2) The total number of internodes of the culm carrying well-developed leaves and which are in active growth at one and the same time is $\mathbf{5}$ and therefore the growth of the whole culm during the period of vigorous activity proceeds at the rate of one complete internode per month.

(3) The period between the commencement of the growth of one internode and of the internode which immediately succeeds it is one month.

If we assume therefore that all the internodes carrying well-developed leaves require the same period for their development and if we consider the life-cycle of the cum to commence from the time when the terminal tuft of $\mathbf{5}$ green leaves each carrying an obvious green lamina has become visible, it is clear that at the end of the first month the first leafy 
internode will be mature, at the end of the second month the second leafy internode will be mature and so on, the terminal length carrying the panicle being four months old, when the long internode immediately below it has become mature, at which time the grain is usually ripe. Whether this explanation, which depends on the assumption that each internode carrying a well-developed leaf at its apex requires the same period for its development, really explains the process and rate of development of the culm in Saccharum spontaneum, or any other species, can of course be only satisfactorily proved by observing the exact time at which each individual internode commences and terminates its growth respectively throughout the life of the culm. In the case of each species also such observations would have to be made on a considerable number of culms in order to obtain an average result. Up to date no opportunity has been available for making such detailed observations satisfactorily, but pending more precise investigation it was considered that, for the purposes of practical work, the following principle might be accepted unless it was found to be obviously at variance with the facts actually observed in the field: the number of mature internodes, each of which carries, or has carried, a well-developed leaf at its apex, produced by a culm during its life-cycle is approximately equal to the number of months constituting its period of vigorous growth, i.e. to the approximate age of the culm in
months.

For the species dealt with in this paper, therefore, the average number of internodes in a mature culm carrying, or which have carried, well-developed leaves ${ }^{1}$ has been calculated
as follows :-

(a) The total number of internodes visible on the mature culm is first counted.

(b) By an examination of the young culms, the number of short basal internodes carrying small scale-like leaves with little or no lamina is determined. (c) Then $(a)-(b)=$ the total number of internodes carrying more or less well-
developed leaves.

So far as possible the number of internodes obtained for each species under $(c)$ was then compared with the number of months of vigorous vegetative activity of that species, as actually observed in the field in the locality from which the culms were obtained, and in all cases where this could be done satisfactorily the agreement between the two numbers was remarkable, while in no species was the period of activity obtained from the calculation found to be in obvious disagreement with the facts observed in the field. It must be noted that, in every case, culms which appeared to be of normal development were selected for observation, i.e. culms obtained from plants which had not been damaged by fire, grazing, or grass-cutting and which had not developed in a locality where the ground-surface level had altered, all of which factors are capable of causing abnormal development.

1 Leaves are usually regarded as "well-developed" when they have a laroe

leaves of the flowering culm (especially the leaf ncxt below the panicle) aften large green lamina, hut it must he noted that the have a long sheath which to some extent functions as a lamina, the panicle) often have a very minute lamina. Such leaves how tho upper have heen considered to be "well-developed" in this paper. 
The results regarding this point which have been obtained, however, up to date can only be regarded as approximations for the following reasons :-

(1) The correct total annual period of vigorous growth for the majority of the culms of a specics in a particular locality can only be determined by observations extending over several years, as this period fluctuates to some extent with the seasons.

(2) The period required for the individual development of leaves and internodes also depends to some cxtcnt on the charactcr of the season and a correct average can only be obtained from observations extcnding over several years. Thus in years when the rains stop abruptly and the soil dries rapidly, the normal period of development of ccrtain internodes would be cut short.

As opportunity permits observations are now being made at Dehra Dun with the object of determining more precisely than has bcen possible up to datc the correct average period of vigorous growth for each species in selected localities and the data thus obtained will indicate how far the approximation which has been provisionally adopted as correct can be relied on.

An average flowering culm of the form of this species usually seen in wet pastures and agricultural lands shows about $9(7-12)$ very short internodes at the base aggregating about an inch in length and then 11 long internodes excluding the terminal segment which terminates in the panicle. The leaves on the basal six short internodes have no green lamina, which gives 14 internodes with green leaves and indicates a period of 14 months' vegetative activity for the production of the culm, which may therefore be described as annual. This form flowers in August-September. The most vigorous growth takes place in the rains from June-September, but there is no marked season of rest and vegetative activity proceeds more or less throughout the year, at all events in the locality now dealt with. The average culm therefore would start its devlopment at the beginning of the rains in July and complete its cycle of $\mathbf{1 4}$ months at the end of August or beginning of September.

The xerophilous form of the species common on dry sand has a slightly shorter period of vegetative activity. Flowering takes place in August and the young culms commence their development chiefly towards the close of the rains in August-September.

The average number of internodes bearing green leaves on the culms examined of this form is 12 , thus indicating a period of 12 months' vegetative activity.

The flowering culms either die back to the ground after flowering, or their basal internodes persist and in the latter case secondary culms are usually developed from their nodes. 
is not as a rule subject to fire damage and excluding this form the plants of this grass, say about January, will usually be found to consist of--

(1) The old flowering culms which flowered in the preceding August-September, and which are as a rule more or less dead and dry, with the exception perhaps of a few of the lower internodes.

(2) The immature young leafy culms most of which vary in size from the just developing buds to culms of $1-2$ feet in length. The latter show four or five mature long internodes and are seven or eight months old. These culms still bear the persistent dead leaves on their lower internodes and terminate in a tuft of five green leaves inserted on still young and immature nodes, which are immediately below the apical bud of the culm.

The old flowering culms and the older of the young leafy culms which carry dry leaves on their lower internodes are more or less inflammable, but the culms are usually slender and the leaves very narrow so that the total quantity of inflammable material is comparatively small.

The damage done by fire consists in the destruction of the basal internodes of the old flowering culms which usually remain alive and from the nodes of which young culms might be developed and in the destruction of the immature leafy culms which would in due season produce flower and seed.

In loamy soil the damage actually done is as a rule very slight for the following reasons :-

(1) The plant there shows a spreading habit of growth in consequence of which the culms are scattered and the intensity of heat developed at any one point is slight.

(2) The soil retains moisture well and conducts heat badly so that the subterranean culm-internodes, buds and young culms are well protected.

On the other hand, the tufted xerophilous form of the plant found on sand is liable to somewhat severe injury. An early fire, while the soil is still a little moist, does little damage, but a fire occurring late in the hot season may penetrate into the soil and destroy not only the aerial part of the plant but also the tufted subterranean culms and thus prove fatal.

Fig. 2, Plate XIV, shows a plant which was almost killed in this way by a forest fire in May 1908, and other plants have been seen which were completely killed.

Ctility as

Fodder and best Treatment for Fodiler Production.
49. This plant is a favourite buffaloe-fodder, especially the hygrophilous form with comparatively broad leaves common near streams, and in such places firing is usually impossible. In drier places at all events. occasional early firing would be probably beneficial by cleaning the clumps of débris, by destroying the [ 60 ] 
old flowering culms and encouraging the production of vigorous young shoots from the ground. It has frequently been noticed that the secondary culms which tend to spring from the basal aerial nodes of the old flowering culms are of inferior vigour to those which originate at or below the ground surface. Duthie writes as follows regarding this plant: "In the Jhang Settlement Report it is stated to be found in the moistest portions of lands adjoining the rivers, where it affords most valuable pasturage for buffaloes. The zamindars of those parts say that if there were no Kanh (local vernacular for kans) there would be no buffaloes, and they consider it too valuable to be used for thatching."

\section{D.-Economic Uses.}

for thatching.

50. The leaves of this species are much used

This plant possesses considerable value on account of its capacity for fixing shifting sand and unstable soil. Any node of a culm which is covered with soil as a rule at once develops vigorous roots and usually also young culms, so that there is no danger of the plant being smothered and killed by accumulations of sand and débris.

In places where it is subjected to the force of a heavy current of water also, although the aerial culms are frequently laid flat, these rapidly root at the nodes and produce new shoots, so that the plant is able to hold the soil with great tenacity and to resist erosion well.

A question connected with this species which is of the greatest economic importance is that of its eradication from agricultural lands. In the Central Provinces this species is responsible for the fact that large areas of valuable soil are at present out of cultivation.

Agricultural soil is usually more or less loamy in which the plant assumes a spreading habit and consequently firing in such cases would be of little value.

The only possible way of attacking the plant appears to consist in some remedy which will starve the subterranean portions of the culms and thus prevent the appearance of vigorous new shoots.

The following plan might in some cases be efficacious :-

(1) After flowering protect the areas from damage by fire or grazing and allow the young culms to develop as vigorously as possible.

(2) About the middle of the following July the areas would ordinarily be covered with a very heavy growth of grass including a proportion of very young culms which commenced vigorous growth at the beginning of the rains. The production of these young culms would tend to diminish the reserve materials in the subterranean portions of the culms available for the production of new culms. The grass should at this period be cut over as close to the ground as possible and the cut grass should be left lying on the area.

${ }^{1}$ Fadd r Grasses of Northern India by J. F. Duthie, p. 25.

[ 61$]$ 
(3) This covering of cut grass by interfering with the access of light should to a considerable extent prevent the production of vigorous young culms.

If leafy branches of trees and shrubs could be strewn over the cut grass the latter would be kept in position and the shade increased.

(4) When the cut grass and branches become thoroughly dry in the cold or beginning of the hot season they should be fired and the area ploughed if possible.

(5) If the grass was still found to be vigorous, it should be again allowed to develop and be again cut over in July before flowering but when a fairly vigorous regrowth of young leafy culms had taken place and the same treatment repeated.

This treatment would undoubtedly to a great extent prevent flowering and the spread of the grass by seed, and as the production and development of leafy culms would he practically prevented during half the normal period of vegetative activity annually, the treatment should have a progressively weakening effect on the plant.

It is possible that in some cases firing in May followed by heavy and continued grazing by buffaloes might be effective. In some localities it has been suggested that flooding the fields to a depth of 2-3 feet might smother and kill the grass, but a possible result of such treatment, which moreover is not easy to put into practice, would be to produce the most vigorous form of the species, viz. variety nepalense.

\section{Saccharum Munja, Roxb. (Plates III and XIX-XXI.)}

References.

Distribution.

F. B. I., VII, 119 (under S. arundinaceum in part only).

H., 118 (under S. ciliare Anderss. excl. vars. $\beta$ and $\gamma$ ); P., II, 1189.

Chiefly found in Northern India, in the Punjab and Upper Gangetic Plain.

\section{A.-DESCRIPTION.}

Vernacular Name.

Culm.
Munj, munja, sar, sarkara, ekar (Dehra Dun).

Erect, attains a height of $18 \mathrm{ft}$. and dia. $0.5 \mathrm{in}$.

In dry unfavourable localities the height is much less, often not exceeding 6 or $7 \mathrm{ft}$.

Pale straw-coloured, smooth, striate and solid.

Shortly silky at extreme base, otherwise quite smooth, striate, pale straw-coloured.

Villous on margins at apex with long white hairs. Longer and usually much longer than proper internode, uppermost sheath snmetimes extending beyond the base of the panicle. 
Upper leaf of flowering culm $9^{\prime \prime}-2 \frac{1}{2} \mathrm{ft}$. long, flat, tapering from base, long acumin- Lamina. ate, width at base $0 \cdot 2 \mathrm{in}$. to $0.4 \mathrm{in}$.

Lower leaves attaining a length of $7 \mathrm{ft}$. (8 ft. fide Roxburgh) and width of 1 in., but as a rule width not exceeding $0 \cdot 75 \mathrm{in}$. and in unfavourable localities sometimes not exceeding $0 \cdot 13 \mathrm{in.}$ wide.

Greatest width usually about the middle. Apex long acuminate and narrowed towards the base. In basal leaves ${ }^{1}$ the concave mid-rib occupies $\frac{1}{2}$ or more of width of lamina at base (often the entire width of the leaf).

Colour glaucous, mid-rib white. The glaucous colour is caused by a thin covering of wax.

Margin scabrid and also scabrid, often only on one side of the leaf, on 1 or more intramarginal nerves below, otherwise smooth but denscly white villous at base behind the ligule.

Truncate, usually a narrow membranous rim not exceeding $0.07 \mathrm{in}$. high. Of upper ugale. leaves longer attaining $0 \cdot 13$ in.

Minutely silky dorsally and ciliate.

Spikelets in pairs, one pedicelled and one sessile on the capillary jointed branches and Inflorescence. branchlets of a terminal panicle.

Primary rachis glabrous, sulcate, more or less scabrid on ridges.

Primary branches sub-verticillate, compound. Ultimate branchlets triquetrous, more or less villous with long white hairs on angles and on two faces.

Flowering panicle 1- -3 ft. long, usually lanceolate, pale cream-coloured to dark reddish-purple, branches spreading.

Fruiting panicle oblong, branches adpressed to axis, white to greyish-white in colour.

Awnless, lanceolate, $0 \cdot 15$ to $0 \cdot 2$ in. long. Sessile and pedicelled similar, each one splkelets. flowered and $\hat{\phi}$.

Pedicelled fruiting spikelet falling from the pedicel, the sessile spikelet falling later with the attached pedicel and joint of axis.

Joint of axis triquetrous, $\frac{1}{2}$ to subequal sessile spikelet but usually shorter than spikelet, villous on two faces and on margins, villi overtop joint by once to twice length of joint.

Pedicels triquetrous $\frac{1}{3}$ to $\frac{3}{4}$ sessile spikelet. Majority of pedicels shorter than proper joint, rarely subcqual proper joint. Pedicels villous with long white hairs on two faces and on angles.

Callus hairs shorter than to subequal the spikelet.

Lanceolate, chartaceous, with 2 strong lateral nerves and usually $1-4$ more or less sessile distinct, but fainter, additional nerves.

Dorsally long villous on basal half or two-thirds, the hairs ovcrtopping the glume hy about the glume's lengih.

${ }^{1}$ Basal leaves are those which mature on the immature 1-year eulms. 
Scabrid dorsally on keels.

Margin inflexed, sparsely ciliate above.

Apex minutely bi-dentate to entire.

Glume II.

Subequal to I. Lanceolate, chartaceous, keeled. With one strong central nerve and usually 2-4 more or less distinct, but fainter, additional nerves.

Glabrous dorsally or minutely pubescent towards apex, scabrid dorsally on keelmargins incurved, ciliate above.

Apex usually shortly mucronate.

Glume IIl. Oblong-lanceolate, hyaline-membranous, a little shorter than II, 1-3 nerved.

Margins incurved, ciliate.

Apex acute or short mucronate.

Glume IV. $\quad$ Broad lanceolate to slliptic. Shorter than or subequal II.

Hyaline, 1-3 nerved. Mucronate. Ciliate.

Mucro short to $0.05 \mathrm{in}$. long, but not exserted beyond the apex of the spikelet.

Pale. $\quad$ Ovate, hyaline, ciliate, from $\frac{1}{3}$ to $\frac{3}{4}$ IV.

Pedicelled

Similar, but glumes I and II are both dorsally long villous and usually with $3-5$ strong nerves and occasionally two additional fainter nerves.

Lodicules.

Anthers.

Stigmas.

Field

Characters.

Two, cuneate, glabrous, $0.02 \mathrm{in.} \mathrm{long.}$

Three, pale yellow to purple, $0 \cdot 08$ to $0 \cdot 10$ in. long.

Yellow, often tinted with purple, 0.04 in. to 0.06 in. long.

The glaucous narrow leaves, awnless spikelets and smooth leaf-sheaths at once distinguish this species from Erianthus Ravennoe, with which it is sometimes confused in the field.

Anatomy. The striking contrast, as regards colour, afforded by the glaucous leaves of S. Munja and the dark green leaves of $S$. Narenga, suggested that there might be considerable anatomical differences in the leaves of these species. Examination, however, showed that there were no anatomical differences which would account for this contrast, the glaucous colour of the leaves of S. Munja being due to a superficial waxy deposit which is especially copious on the under-surface. The general structure of the leaf and the disposition of the chlorenchyma in these two species is similar and resembles that of Imperata described below. The chlorenchyma is arranged in more or less complete rings around the vascular bundles and is mainly disposed near the lower epidermis, the chlorenchyma strips flanking the larger nerves, alone, reaching the upper epidermis, while a band, $4-6$ cells wide, of colourless bulliform cells is situated over the smaller nerves and the chlorenchyma ivhich surrounds them. 


\section{B.-Taxonomy.}

51. Hackel (l.c., p. 117) distinguishes two species mainly on the following characters:-

Saccharum arundinaceum Retz.--Leaves broad linear. Width 2-3 cm. $\left(0 \cdot 8^{\prime \prime}-\right.$ $\left.1 \cdot 2^{\prime \prime}\right)$. Mid-rib at base of lamina much narrower than width of lamina. Joints of panicle usually longer than spikelet. Sessile spikelet 3.5 to $4 \mathrm{~mm}$. $\left(0 \cdot 14^{\prime \prime}\right.$ to $\left.0 \cdot 16^{\prime \prime}\right)$ long.

Saccharum ciliare Anderss. (= Saccharum Munja Roxb.).-Leaves narrow linear. Width 3 to $6 \mathrm{~mm}$. $\left(0 \cdot 12^{\prime \prime}\right.$ to $\left.0 \cdot 24^{\prime \prime}\right)$. Mid-rib at base of lamina more than half width of lamina. Joints of panicle shorter than spikelet. Spikelets $5-7 \mathrm{~mm} \cdot\left(0 \cdot 2^{\prime \prime}-0 \cdot 28^{\prime \prime}\right)$ long.

Both the above plants havie been combined in the Flora of British India (VII, p. 119) in one species named Saccharum arundinaceum Retz., but a comparison of Plate XIX with fig. 1, Plate XXII, will indicate how distinct these two plants really are, and there can be little doubt that they must be regarded as distinct species. Fig. 1, Plate XXII, is a photograph of a plant of Saccharum arundinaceum Retz. growing in a garden at Dehra Dun which was kindly identified in the first place by Dr. Otto Stapf and which the writer was subsequently able to compare with a co-type in the Herbarium of the British Museum. As indicated in the photograph Saccharum arundinaceum is a plant with strongly hygrophilous characters and it attains gigantic dimensions. The writer has measured culms $24 \mathrm{ft}$. in length and $0.75 \mathrm{in}$. in diameter and these dimensions are probably exceede 1 in favourable localities. The leaves are dark green and attain a length of $6 \mathrm{ft}$. and a width of $2 \mathrm{in}$. whereas those of Saccharum Munja are glaucous and have never been found to exceed 1 in. in width. The immature leafy culms of Saccharum arundinaceum show a solid mature, basal, piece of culm of $5-6 \mathrm{ft}$. in length terminating in the apical tuft of green leaves, whereas in Saccharum Munja the mature basal portion of the immature culms does not as a rule exceed 2 in. The great length of the immature culms gives Saccharum arundinaceum a very distinctive and characteristic appearance, totally unlike that of any other Indian species of Saccharum with the sole exception of the cultivated Sugar-cane, Saccharum officinarum. Saccharum arundinaceum is undoubtedly identical with the Saccharum procerum of Roxburgh and the latter was clearly acquainted with the characteristic habit of the plant since he describes it as coming "nearest in appearance to Saccharum officinarum" (l.c., p. 243). A peculiarity of this plant is that the spikelets (in the specimens seen by the writer the pedicelled spikelets) are sometimes (? only in cultivated plants) $2-3$ flowered and inside glumes III and IV there are in such cases 1-2 additional hyaline, paleate, glumes. Retzius (Obs. bot., fasc. IV, p. 14, and fasc. V, p. 16) says that his Saccharum arundinaceum and Saccharum bengalense are practically identical except that the "coroita of the former is often 3-valued and of the latter 2-valved" and there is little doubt that 
these plants belong to the same species. Saccharum arundinaceum is a native of the Evergreen Zone of India characterised by a rainfall exceeding $70 \mathrm{in}$., but it is not infrequently cultivated in gardens throughout India. The type of Retzius was probably a cultivated plant and he notes (l.c.) that it is "colitur juxta sepes et ad stagnorum margines prope Tranquebar." It is indigenous in Bengal, Assam, and Burma, and extends to China. As regards the specific value of Saccharum arundinaceum and Saccharum Munja respectively, and as indicating that these plants are not œcological forms of the same species which owe their peculiarities to variations in the available water supply, it is interesting to note that the rainfall of Dehra Dun is 80 in., that Saccharum arundinaceum grows well there in gardens not liberally supplied with water but is not found wild in the locality, that on the other hand Saccharum Munja is indigenous and very common in the locality but that although the latter has been found in habitats with great differences in the available moisture supply and on soil varying from practically waterless sand to moist loam (which results in a variation of the leaf-width of this plant from $0.13 \mathrm{in}$. to $1.0 \mathrm{in}$.) no indication has been found of a tendency in Saccharum Munja to assume the characteristics of Saccharum arundinaceum.

As regards Saccharum ciliare Anderss. there is no doubt that this includes the plants described by Roxburgh as Saccharum Sara and Saccharum Munja. ${ }^{1}$

Roxburgh's drawing of Saccharum Sara at Calcutta represents a plant with an unusually dense, compact fruiting panicle. The density of the panicle however in this genus is in itself not a character of specific importance and has been found to vary in one and the same undoubted species. It depends largely on the age of the panicle and the way in which it has dried or matured. There is moreover no authentic specimen of this plant named by Roxburgh. There is a sheet from Roxburgh's collection in the British Museum which has been named Saccharum Sara in pencil, probably by Solander, and this is typical Saccharum Munja Roxb. On the other hand the name Saccharum Munja is supported not only by the description in Flora Indica and by an excellent drawing, but also by a specimen in the British Museum named by Roxburgh. Hackel (l.c., p. 119) gives Andersson's name precedence over the Saccharum Munja of Roxburgh on the ground that the description of the latter plant as having a "two-valved corol" necessarily implies the absence of the pale.

It has however been shown on p. 53 above that this inference is not justified. The type also has been examined by the writer and there is no doubt that the pale is present both in the sessile and pedicelled spikelets. Hence the name Saccharum Munja Roxb. must stand and it is believed that Indian botanists will appreciate the restoration of this wellknown and appropriate namis. In his Saccharum ciliare Hackel includes a plant which he describes as variety Griffthii and which is characterised by having glume II of the sessile spikelet dorsally villous and not glabrous as in Saccharum Munja proper. In the Flora of British India (p. 122) a new species is established under the name of Erianthus Griffuthii 
Hook f. which includes Hackel's var. Griffithii. The establishment of this species is the result of including a specimen collectcd by Thomson at Rondu, Tibet, which has spikelets with exserted awns. This specimen however undoubtedly belongs to Erianthus Ravennce (a species which varies considerably as regards its dimensions and the width of its leaves according to the amount of moisture available in the habitat) and consequently the species Erianthus Griffithii cannot be maintained. ${ }^{1}$

Hackel's variety Griffithii is identical with Saccharum Griffthii Munro, accepting the plant, which was actually given this name by General Munro himself, as this species (vide 1193 Griffith and 666 Herb. Falconer in Herb. Kew).

The first valid publication of this name however appears to be in Boissier's Fl. Or., V, 453 (1884), and this author, while unfortunately assigning specimens (Aitchison's 467, 546), which are undoubtedly conspecific with the numbers quoted above, to the entirely different plant Saccharum Sara Roxb., applies the name Saccharum Griffithii Munro to a sheet in his own herbarium (No. 507) which was apparently collected by Stocks (fide Hackel Mon. Androp., 119), and which has not been seen by the writer.

It is possible that Boissier's 507 is really referable to the Saccharum Griffithii of Munro but its spikelets are longer ( $8 \mathrm{~mm}$., fide Boiss., $7 \mathrm{~mm}$., fide Hackel) than in any specimen of the latter plant seen by the writer.

If Boissier's plant is referable to a hitherto unpublished species his plant should, under a strict application of the rules of priority, be called Saccharum Griffithii Munro, but, under the peculiar circumstances of this case, it appears reasonable to keep this name for the plant to which Munro undoubtedly gave it.

Under this view, if Boissier's plant proves to be a different species, the date of valid publication of Saccharum Griffithii will be that of the present paper.

A brief Latin diagnosis of this plant is accordingly given below.

Saccharum Griffithii is closely allied to Saccharum Munja and exhibits marked xerophilous characters, but, although the writer has found Saccharum Munja in waterless stations with leaves only $0 \cdot 13 \mathrm{in}$. wide, no tendency to assume the villous glume II of the sessile spikelet and other characters of Saccharum Griffithii has been seen.

Seeing, therefore, that the plant, considered a variety by Hackel, is distinguished by important and well-defined characters and has a distinct geographical range, it seems preferable to deal with it as a distinct species under the name of Saccharum Griffithii Munro.

1 In F. B. I. (VII, 121) it is rightly pointed out that the separation of Saccharum from Erianthus solely on the cbaracter of the exserted awn is unsatisfactory and that a careful study of the species constituting these geuera is advisable with a view to testing their validity. The plants concerned are not always easy to discriminate in the herbarium and s eareful study of representative species in the field is essential before a sound reclassification is attempted. It is hoped that the present paper will serve as a small eontribution to that end. Whatever the resnlt of sueh study may be, the name Erianthus Friffithii, which was hased on an error (viz. the assumption that the spikelets are awned), should obriously not be maintained.

It should be noted that, so far as Erianthus Ravenne is coneerned, the writer has found the exserted awn a reliable and coustant character, clearly separating it from all the speeies at present classified as Saecharums. 
The following classification, therefore, of the forms now under consideration appears to be the best :-

1. Saccharum arundinaceum Retz. (Obs. bot., fasc. IV, p. 14, 1786).

Syn.-S. bengalense Retz.

S. procerum Roxb.

Ref.-Roxburgh, l.c., p. 243.

Hackel, l.c., p. 117, excl. syn. S. exaltatum.

Vern.-Ramsar (Dihra Dun), Teng (Bengal).

Habitat.-Bengal (Darjeeling 3,500', C. B. Clarke; Valleys of Sikkim 14,000', J. D. Hooker; Chittagong, $0-1,000^{\prime}$, Hooker and Thompson), Assam (Griffith; Khasia Hills 2-4,000', Hooker and Thompson), Burma (Banks of Salween River), Southern India (Tanjore; cultivated or indigenous?).

Distribution.-China.

Illustrations.-See Plate XXII.

Notes.-This plant is commonly cultivated in India in gardens and near villages, as it is of some medicinal value.

II. Saccharum Munja Roxb. (l.c., p. 246, 1832).

Syn.-S. Sara Roxb.

S. ciliare Anderss. in CEfvers K. Vet. Akad. Förhand. Stockh., p. 155, 1855.

Ref.-Roxburgh, l.c., pp. 246, 244.

Hackel, l.c., p. 118, excl. vars. $\beta$ Griffthii and $\gamma$ Boissieri.

Vern.-Munj, munja, sar, sarkara, ekar (Dehra Dun), Sara (Bengal).

Habitat.-Northern India in the Punjab and Upper Gangetic Plain, extends into Sindh (fide Hackel). Is occasionally cultivated, e.g. near Calcutta. ${ }^{1}$

Illustrations.-See Plates III and XIX-XXI.

\section{Saccharum Griffithii Munro.}

Syn.-S. Sara, Aitchison, in Journ. Linn. Soc., XIX, p. 191.

S. Sara Boiss., Fl. Or., V, 453.

? S. Griffithii Boiss., l.c.

S. ciliare var. Griffthii Hackel, l.c., 119.

Erianthus Griffthii Hook f. (in part), F. B. I., VII, 122.

${ }^{1}$ Vegetation of the Districts of Hughi-Howrah and the 21-Pergunnahs by D. Prain in Records Botanical Survey of India, Vol. III, No. 2, 1905 . 
Ref.-Griffith, Itinerary Notes, 316.

Description.-Cespitosum. Culmi 2 m., vel paulo aitiores, farcti. Vaginæ non hirsutie, nodis imberbibus, laminis glaucis anguste lincaribus usque ad $8 \mathrm{~mm}$. latis. Racemorum rhachis fragilis. Spiculie ad quemvis rhacheos nodum binæ, altera sissilis cum articulo accumbente demum decidens, altera pedicellata, a pedicello demum soluta, utraque uniflora, $\hat{\ddagger}$.

Spiculæ 4-6 mm. longæ, muticæ.

Pedicelli articulique spiculis breviores.

Pedicelli plerumque articulos proprios subrquantes vel eis longiores.

Callus villis gilvis spiculas subæquantibus vel eis brevioribus dense vestitus.

Gluma $I^{a}$ et $I^{a}$ et sessilis et pedicellatæ spiculæ chartaceo-membranaceæ pilis glumas non, vel vix, superantibus dorso villosæ.

Gluma III ${ }^{a}$ dorso nune glabra nunc parce hirsuta.

Gluma TV $\mathrm{TV}^{\mathrm{a}}$ mucronata. Mucro usque ad $1 . \tilde{\mathrm{j}} \mathrm{mm}$. longus non ab apice spiculæ exsertus.

Afghanistan : Griffith, 1193.

Aitchison, 271, 467, 546 .

Baluchistan : Stocks, 1209.

Punjab: Attock, Herb. Falconer, 666.

Sindh : fide Hackel, l.c., 119.

Notes.-Aitchison (l.c., 143) writes as follows regarding this species: "Along the edges of the dry water-courses, and on the higher island-like plots of ground in the beds of these dried-up streams, Saccharum Griffithii, a great coarse stiff grass, occurring in large tussocks, is very striking, owing to the absence of other vegetation generally than to any peculiarity of its own."

From what has been said above it will be clear that there has been some confusion between S. arundinaceum, S. Munja, S. Griffithii and Erianthus Ravennce. As S. Munja is of considerable economic importance it is obviously desirable that the characters distinguishing it from the other less valuable species should be clearly defined.

$$
\text { [ } 69 \text { ] }
$$


For this purpose and with the object of indicating at a glanoe most of the important characters of the species of Saccharum and Erianthus dealt with in this paper the following comparative table is given :-

\begin{tabular}{|c|c|c|c|c|c|}
\hline $\begin{array}{l}\text { Saccharnm sponta- } \\
\text { neum (Indian form). }\end{array}$ & $\begin{array}{l}\text { Saccharum } \\
\text { arundinaceum. }\end{array}$ & Sacrharum Munja. & Saccharum Griffithii. & Sacoharum Narenga. & $\begin{array}{l}\text { Erianthus Ravennæ } \\
\text { (Indian form). }\end{array}$ \\
\hline $\begin{array}{l}\text { Frequently not form- } \\
\text { ing defined tufts. }\end{array}$ & $\begin{array}{l}\text { Forms well-defined } \\
\text { tufts. }\end{array}$ & $\begin{array}{l}\text { Forms well-defined } \\
\text { tufts. }\end{array}$ & $\begin{array}{l}\text { Forins well-defined } \\
\text { tufts. }\end{array}$ & $\begin{array}{l}\text { Usually forms well- } \\
\text { defined tufts, but } \\
\text { sometimes spread- } \\
\text { ing. }\end{array}$ & $\begin{array}{c}\text { Forms } \\
\text { tufts. }\end{array}$ \\
\hline Colms anuual . & $\begin{array}{l}\text { Culms biennial (? or } \\
\text { triennial). Mature } \\
\text { basal portion of } 1 \text { - } \\
\text { year (? or } 2 \text {-year) } \\
\text { culms attains } 6 \text { feet } \\
\text { in length. }\end{array}$ & $\begin{array}{l}\text { Culms biennial. Ma- } \\
\text { ture basal portion } \\
\text { of 1-year culms } \\
\text { usually not exceed- } \\
\text { ing } 2 \text { in. }\end{array}$ & $\begin{array}{l}\text { Duration of culms not } \\
\text { known. }\end{array}$ & $\begin{array}{l}\text { Culms biennial. Ma- } \\
\text { ture basal portion } \\
\text { of 1-yar calms } \\
\text { usually not exceed- } \\
\text { ing } 2 \text { in. }\end{array}$ & $\begin{array}{l}\text { Culms biennial. Ma- } \\
\text { ture basal portion } \\
\text { of 1-year calms - } \\
\text { usually not exceed- } \\
\text { ing } 2 \text { in. }\end{array}$ \\
\hline $\begin{array}{l}\text { Flowering calm solid } \\
\text { above, fistular below, } \\
\text { attains } 20 \mathrm{ft} \text {. and } \\
\text { dia. } 0.6 \mathrm{in.}\end{array}$ & $\begin{array}{l}\text { Flowering culm solid, } \\
\text { attaing } 24 \mathrm{ft} \text {. and } \\
\text { dia. } 0.75 \mathrm{in} \text {. }\end{array}$ & $\begin{array}{l}\text { Flowering culm solid, } \\
\text { attains } 18 \mathrm{ft} \text {. and } \\
\text { dia. } 0.5 \mathrm{in} .\end{array}$ & $\begin{array}{l}\text { Flowering culm solid, } \\
\text { is said to attain } 7 \\
\text { ft. }\end{array}$ & $\begin{array}{l}\text { Flowering culm solid, } \\
\text { attains } 16 \mathrm{ft} \text { and } \\
\text { dia. } 0.5 \mathrm{in} \text {. }\end{array}$ & $\begin{array}{l}\text { Flowering culm solid, } \\
\text { attains } 19 \mathrm{ft} \text {. and } 0.7 \\
\text { in. dia. }\end{array}$ \\
\hline $\begin{array}{l}\text { Lamina glaucous, at- } \\
\text { tains } 4 \mathrm{ft} \text {, in length } \\
\text { (Roxburgh gives } 7 \\
\text { ft.) and } 0.7 \text { in. in } \\
\text { width. }\end{array}$ & $\begin{array}{l}\text { Lamina dark green, } \\
\text { attains } 6 \mathrm{ft} \text {. and } \\
\text { width } 2 \mathrm{ia} .\end{array}$ & $\begin{array}{l}\text { Lamins glaucous, at- } \\
\text { tains } 7 \mathrm{ft} \text {. in length } \\
\text { and } 1 \text { in. width. }\end{array}$ & $\begin{array}{l}\text { Lamina glaucous, nar- } \\
\text { row. Has been seen } \\
0.3 \text { in. wide in her- } \\
\text { barium specimens, } \\
\text { but probably attains } \\
\text { a greater width. }\end{array}$ & 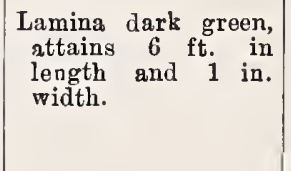 & $\begin{array}{l}\text { Lamina dark green, } \\
\text { attains } 6 \text { ft. in } \\
\text { length and width. } \\
1.5 \text { in. }\end{array}$ \\
\hline $\begin{array}{l}\text { Midrib at base usu- } \\
\text { ally occupies more } \\
\text { than width of } \\
\text { lamiua. }\end{array}$ & $\begin{array}{l}\text { In basal leaves } \\
\text { midrib at base occu- } \\
\text { pies } \frac{1}{3} \text { or less of the } \\
\text { width of the lamina. }\end{array}$ & $\begin{array}{l}\text { In basal leaves } \\
\text { midrib at base occu- } \\
\text { pies } \frac{1}{2} \text { or more of } \\
\text { width of lamina. }\end{array}$ & $\begin{array}{l}\text { Midrib at base usu- } \\
\text { ally occupies } \frac{1}{3} \text { or } \\
\text { more of width of } \\
\text { lamina. }\end{array}$ & $\begin{array}{l}\text { In basal leaves }{ }^{2} \\
\text { midrib at base occu- } \\
\text { pies t or less of the } \\
\text { width of lamina. }\end{array}$ & $\begin{array}{l}\text { In basal leaves } \\
\text { midrib at base occu- } \\
\text { pies } \\
\text { width of lamina. }\end{array}$ \\
\hline $\begin{array}{l}\text { Lcaf-sheath not bir- } \\
\text { sute. } \\
\text { Leaf-insertions not }\end{array}$ & $\begin{array}{l}\text { Leaf-sheath not hir- } \\
\text { sute. } \\
\text { Leaf-insertions not }\end{array}$ & $\begin{array}{l}\text { Leaf-sheath not hir- } \\
\text { sate. } \\
\text { Leaf-insertions not }\end{array}$ & $\begin{array}{l}\text { Leaf-sheath not hir- } \\
\text { sute. } \\
\text { Leaf-insertions not }\end{array}$ & $\begin{array}{l}\text { Leaf-sheath hirsute } \\
\text { with bulbous-based } \\
\text { hairs. }\end{array}$ & $\begin{array}{l}\text { Leaf-sheath hirsute } \\
\text { with bulbous-based } \\
\text { hairs. }\end{array}$ \\
\hline bearded. & bearded. & bearded. & bearded. & $\begin{array}{l}\text { Leaf-insertions long- } \\
\text { bearded. }\end{array}$ & $\begin{array}{l}\text { Leaf-insertions short- } \\
\text { ly and finely beard- } \\
\text { ed. }\end{array}$ \\
\hline $\begin{array}{l}\text { Spikelets } 0.08-0.2 \text { in. } \\
\text { long }(2-5 \mathrm{~mm} .) \text {. }\end{array}$ & $\begin{array}{l}\text { Spikelets } 0^{\prime} 1-0 \cdot 15 \text { in. } \\
\text { long }\left(2 \frac{1}{2}-4 \mathrm{~mm} .\right)\end{array}$ & $\begin{array}{l}\text { Spikelets } 0.15-0.2 \mathrm{in.} \\
\text { long }(4-5 \mathrm{~mm} .)\end{array}$ & $\begin{array}{l}\text { Spikelets } 0 \cdot 15-0 \cdot 24 \mathrm{in} . \\
\text { long }(4-6 \mathrm{~mm} .)\end{array}$ & $\begin{array}{l}\text { Spikelets } 0.08-0.13 \text { in. } \\
\text { long }\left(2-3 \frac{1}{2} \mathrm{~mm}\right)\end{array}$ & $\begin{array}{l}\text { Spikelets } 0.13-0.16 \text { in. } \\
\text { long }\left(3 \frac{1}{2}-4 \mathrm{~mm} .\right)\end{array}$ \\
\hline $\begin{array}{l}\text { Pedicel }{ }^{3} \frac{1}{4}-1 \frac{1}{4} \text { sessile } \\
\text { spikelet. } \\
\text { Usually shorter than } \\
\text { sessile spikelet. }\end{array}$ & $\begin{array}{l}\text { Pedicel } \frac{2}{3} \text { to equal } \\
\text { sessile spikelet. }\end{array}$ & $\begin{array}{l}\text { Pedicel } \frac{1}{3}-\frac{3}{4} \text { sessile } \\
\text { spikelet. }\end{array}$ & $\begin{array}{l}\text { Pedicel }{ }^{\frac{1}{3}-\frac{2}{3}} \text { sessile } \\
\text { spikelet. }\end{array}$ & $\begin{array}{l}\text { Pedicel } \frac{1}{2}-\frac{3}{4} \text { sessile } \\
\text { spikelet. }\end{array}$ & $\begin{array}{l}\text { Pedicel } \frac{1}{4}-\frac{8}{4} \text { sessile } \\
\text { spibelet. }\end{array}$ \\
\hline $\begin{array}{l}\text { Joint }{ }^{3} \text { longer or } \\
\text { shorter than sessile } \\
\text { spikelet. }\end{array}$ & $\begin{array}{l}\text { Joint usually longer } \\
\text { than sessile spikelet } \\
\text { (y to } 1 \frac{8}{6} \text { sessile } \\
\text { spikelet). }\end{array}$ & $\begin{array}{l}\text { Joint usually shorter } \\
\text { than sessile spikelet } \\
\left(\frac{1}{2} \text { to subequal }\right. \\
\text { sessile spikelet). }\end{array}$ & $\begin{array}{l}\text { Joint } \frac{1}{4}-\frac{2}{3} \text { sessile } \\
\text { spikelet. }\end{array}$ & $\begin{array}{l}\text { Joint } \frac{1}{2}-1 \frac{1}{2} \text { sessile } \\
\text { spikelet, but usually } \\
\text { shorter than to sub- } \\
\text { equal spikelet. }\end{array}$ & $\begin{array}{l}\text { Joint }{ }^{\frac{1}{4}}-\frac{2}{3} \text { sessile } \\
\text { spikelet. }\end{array}$ \\
\hline $\begin{array}{l}\text { Pedical shorter than } \\
\text { proper joint. }\end{array}$ & $\begin{array}{l}\text { Diajority of pedicels } \\
\text { shorter than proper } \\
\text { joiut. }\end{array}$ & $\begin{array}{l}\text { Majority of pedicels } \\
\text { shorter than proper } \\
\text { joint (rar'ely sub- } \\
\text { equal to proper } \\
\text { joint). }\end{array}$ & $\begin{array}{l}\text { Majority of pedicels } \\
\text { subequal to longer } \\
\text { than proper joint. }\end{array}$ & $\begin{array}{l}\text { Majority of pedicels } \\
\text { shorter than to sub- } \\
\text { equal proper joint. }\end{array}$ & $\begin{array}{l}\text { Majority of pedicels } \\
\text { longer than proper } \\
\text { joint. }\end{array}$ \\
\hline $\begin{array}{l}\text { Callus hairs white, } \\
1_{2}^{1}-7 \text { times as long } \\
\text { as sessile spikclet. }\end{array}$ & $\begin{array}{l}\text { Callus hairs pale, } \\
\text { shorter than to sub- } \\
\text { equal spikelet. }\end{array}$ & $\begin{array}{l}\text { Callus hair pale, often } \\
\text { purplish, shorter } \\
\text { than to subequal } \\
\text { spikelet. }\end{array}$ & $\begin{array}{l}\text { Callus hairs yellow, } \\
\text { shorter than to sub- } \\
\text { equal spikelet. }\end{array}$ & $\begin{array}{l}\text { Callus hairs usually } \\
\text { purple, subequal } \\
\text { spikelet. }\end{array}$ & $\begin{array}{l}\text { Callus hairs parplish } \\
\text { of brownish, shorter } \\
\text { than to subequal } \\
\text { spikelet. }\end{array}$ \\
\hline
\end{tabular}

1 Basal leaves are those which mature on the immature 1-year (P 2-year) culms.

2 Basal leaves are those which mature on the immature 1-year culms.

${ }^{3}$ In recording the lengths of pedicels and joints of all species the basal pedicel and joint of each paniclc-branch have been omitted as these often vary irregularly. 


\begin{tabular}{|c|c|c|c|c|c|}
\hline $\begin{array}{l}\text { Saceharum sponta- } \\
\text { neum (Indian form). }\end{array}$ & $\begin{array}{c}\text { Saecharum } \\
\text { arundinaceum. }\end{array}$ & Sacclarum Munja. & Saccharum Griffthii. & Saccharum Narenga. & $\begin{array}{l}\text { Erianthus Ravennio } \\
\text { (Inclian form). }\end{array}$ \\
\hline $\begin{array}{l}\text { Hairs of joint overtop } \\
\text { joint by } 2 \text { to } 3 \text { times } \\
\text { length of joint. }\end{array}$ & $\begin{array}{l}\text { Hairs of joint overtop } \\
\text { joint by less than to } \\
1 \frac{1}{2} \text { times joint's } \\
\text { length. }\end{array}$ & $\begin{array}{l}\text { Hairs of joint overtop } \\
\text { joint by once to } \\
\text { twice length of joint. }\end{array}$ & $\begin{array}{l}\text { Hairs of joint overtop } \\
\text { joint by once to } \\
\text { twice length of joint. }\end{array}$ & $\begin{array}{l}\text { Hairs of joint overtop } \\
\text { joint by less than } \\
\text { joint's length. }\end{array}$ & $\begin{array}{l}\text { IIairs of joint overtop } \\
\text { joint by twice length } \\
\text { of joint. }\end{array}$ \\
\hline $\begin{array}{l}\text { Glume I sessile spike- } \\
\text { let coriaceous in } \\
\text { basal third. Not } \\
\text { villous dorsally. }\end{array}$ & $\begin{array}{l}\text { Glume I sessile spike- } \\
\text { let chartaceons. } \\
\text { Dorsally sparsely } \\
\text { villous. Villi over- } \\
\text { toppiug glume by } \\
\text { about } 1 \frac{1}{4} \text { glume's } \\
\text { length. }\end{array}$ & $\begin{array}{l}\text { Glume I sessile spike- } \\
\text { let chartaceous. } \\
\text { Dorzally densely } \\
\text { villons (in basal } \frac{1}{2}- \\
\frac{2}{3} \text {. Villi overtop- } \\
\text { ping by about } \\
\text { glume's length (1- } \\
\text { 1! glume's length). }\end{array}$ & $\begin{array}{l}\text { Glume I sessile spike- } \\
\text { let chartacrons. } \\
\text { Dorsally densely } \\
\text { villous (in basal } \\
\frac{2}{3} \text { ). Villi not } \\
\text { overtopping glume, } \\
\text { or overtopping by } \\
\text { less than glume"s } \\
\text { length. }\end{array}$ & $\begin{array}{l}\text { Glume I sessile spike- } \\
\text { let coriaceous. Vil. } \\
\text { lous or not villous } \\
\text { doranlly. Villi not } \\
\text { overtopping } \\
\text { glume. }\end{array}$ & $\begin{array}{l}\text { Glume I sessile spike- } \\
\text { let chartaccons. } \\
\text { Villous or not vil- } \\
\text { lous dorsally. Villi } \\
\text { lot overtopping } \\
\text { glune or overtopping } \\
\text { by lcss than } \frac{1}{2} \text { glume's } \\
\text { length. }\end{array}$ \\
\hline $\begin{array}{l}\text { Glume II sessilo spike- } \\
\text { let coriaceous in } \\
\text { basal third. Not } \\
\text { villous dorsally. }\end{array}$ & $\begin{array}{l}\text { Glume II sessile } \\
\text { spikelet chartaceous. } \\
\text { Not villous dorsally. }\end{array}$ & $\begin{array}{l}\text { Glume II of sessile } \\
\text { spikclet charta- } \\
\text { eeous. Not villous } \\
\text { dorsally. }\end{array}$ & $\begin{array}{l}\text { Glume II sessile } \\
\text { spikelet charti- } \\
\text { ceons. Dorsally vil- } \\
\text { lous (in basal to } \\
\frac{2}{3} \text { ). Villi not } \\
\text { overtopping or over- } \\
\text { topping by less than } \\
\frac{1}{4} \text { glume's length. }\end{array}$ & $\begin{array}{l}\text { Glume II sessile } \\
\text { apikelet coriaceous. } \\
\text { Villous or not vil. } \\
\text { lous dorsally. Villi } \\
\text { not overtopping the } \\
\text { glume. }\end{array}$ & $\begin{array}{l}\text { Glume II sessile spike- } \\
\text { let chartaceous. Vil- } \\
\text { lous or not villous } \\
\text { dorsally. Villi not } \\
\text { overtopping glume } \\
\text { or overtopping by } \\
\text { less than glume's } \\
\text { length. }\end{array}$ \\
\hline $\begin{array}{l}\text { Glume III of sessile } \\
\text { spikelet not villous } \\
\text { dorsally. }\end{array}$ & $\begin{array}{l}\text { Glume } 11 \text { of sessile } \\
\text { spikelet not villous } \\
\text { dorsally. }\end{array}$ & $\begin{array}{l}\text { Glume III of sessile } \\
\text { spikelet not villous } \\
\text { dorsally. }\end{array}$ & $\begin{array}{l}\text { Glume III of sessile } \\
\text { spikelet sometimes } \\
\text { sparsely villous dor- } \\
\text { sally. }\end{array}$ & $\begin{array}{l}\text { Glume III of sessile } \\
\text { spikelet not villoos } \\
\text { dorsally. }\end{array}$ & $\begin{array}{l}\text { Glume III of sessile } \\
\text { spikelet not villous } \\
\text { dorsally. }\end{array}$ \\
\hline Glume IV muticous. & $\begin{array}{l}\text { Mucro of glume IV } \\
0.03-0.05 \text { in. Not } \\
\text { exserted beyond } \\
\text { apex of spikelet. }\end{array}$ & $\begin{array}{l}\text { Mucro of glume IV } \\
\text { very short to } 0.05 \mathrm{in} . \\
\text { Not exserted beyond } \\
\text { apex of spikelet. }\end{array}$ & $\begin{array}{l}\text { Mucro of glume IV } \\
\text { very short to } 0.06 \text { in. } \\
\text { Notexserted beyond } \\
\text { apex of spikelet. }\end{array}$ & Glume IV muticous. & $\begin{array}{l}\text { Mucro of glume IV } \\
0^{\circ} 1 \text { to } 0^{\circ} 23 \text { in. long. } \\
\text { Clearly exserted } \\
\text { from spikelet. }\end{array}$ \\
\hline Pale ciliate. & Pale ciliate. & Pale ciliate. & Pale ciliate. & Pale ciliate. & Pale glabrous. \\
\hline $\begin{array}{l}\text { Glumes I and II pedi- } \\
\text { celled spikelet not } \\
\text { villous dorsally. }\end{array}$ & $\begin{array}{l}\text { Glumes I and II pedi- } \\
\text { celled spikelet dor- } \\
\text { sally villous. Villi } \\
\text { overtopping spikelet } \\
\text { by 1- I times spikc- } \\
\text { let's length. }\end{array}$ & $\begin{array}{l}\text { Glumes I and II pedi- } \\
\text { celled spikelet dor- } \\
\text { sally villous. Villi } \\
\text { overtopping spikelet } \\
\text { by about spikelet's } \\
\text { length ( } \frac{3}{2}-1 \frac{1}{4} \text { length } \\
\text { of spikelet). }\end{array}$ & $\begin{array}{l}\text { Glumes I and II veli- } \\
\text { celled spikelet dor- } \\
\text { sally villous (in } \\
\text { basal } \frac{1}{2} \text { to } \frac{2}{3} \text { ). } \\
\text { Villi not overtop- } \\
\text { ping or overtopping } \\
\text { by less than topiks- } \\
\text { let's length. }\end{array}$ & $\begin{array}{l}\text { Glumes I and II pedi- } \\
\text { celled spikelet vil- } \\
\text { lous or not villous } \\
\text { dorsally. Villi not } \\
\text { overtopping scikelet. }\end{array}$ & $\begin{array}{l}\text { Glumes I and II pedi- } \\
\text { celled spikolet vil- } \\
\text { lous dorsally. Villi } \\
\text { not overtopping or } \\
\text { overtopping by less } \\
\text { than } \\
\text { length. }\end{array}$ \\
\hline $\begin{array}{l}\text { Spikelet } 1 \text { flowered. } \\
\text { No a d d itional } \\
\text { glumes inside III } \\
\text { and IV. }\end{array}$ & $\begin{array}{l}\text { Spikelet sometimes } \\
2-3 \text { flowered with } \\
1-2 \text { addition l pale- } \\
\text { ate, hyaline, mucro- } \\
\text { nate glumes inside } \\
\text { III and IV. }\end{array}$ & $\begin{array}{l}\text { Spikelet } 1 \text { florvered. } \\
\text { Noadditional glumes } \\
\text { inside III and IV. }\end{array}$ & $\begin{array}{l}\text { Spikelet } 1 \text { flowered. } \\
\text { Nu additional glumes } \\
\text { inside III and IV. }\end{array}$ & $\begin{array}{l}\text { Spikelet } 1 \text { flowered. } \\
\text { No additional } \\
\text { glumes inside III } \\
\text { and IV. }\end{array}$ & $\begin{array}{l}\text { Spikelct } 1 \text { flowered. } \\
\text { Noadditional glumes } \\
\text { inside III and IV. }\end{array}$ \\
\hline
\end{tabular}

\section{C.-Biological and CEcological Notes.}

52. The comparatively narrow, hard, glau- Habitat cous leaves of this species show marked xerophilous adaptations and although the plant attains its maximum development on moist sand, it can exist in stations which are typically xerophilous.

Scattered individuals are thus often found on the shingle banks where Aristida is dominant and on dry sand with the xerophilous form of S. spontaneum, but in such localities the plants are more or less stunted and of inferior dimensions.

$$
\left[\begin{array}{ll}
\text { i1 } & ]
\end{array}\right.
$$


On sandy soil, however, which is moist, at least during the greater part of the rainy season, this species is markedly dominant and it probably occupies a larger area than any other savannah grass in Northern India.

It is found also on well-drained loam.

It appears to be decidedly sensitive as regards the aeration of the soil and plants taken from sandy soil and cultivated in well-drained loam showed decidedly inferior development, a fact which was not noticed in the case of Triraphis for example.

It has less capacity for standing shade than either S. Narenga or Erianthus Ravennce, but still it can stand a certain degree of shade, as is shown by the fact that culms are frequently produced under the shade of Zizyphus bushes on grazing grounds. The rapidity with which this grass is killed out by Acacia Catechu is believed to be due not entirely to shade but partly to the arying of the surface soil by the tree roots.

This species is here found at its best on the alluvial sandy deposits in the immediate neighbourhood of the larger streams where the scil is not water-logged and where it can establish itself on unoccupied areas, free from the injurious competition in respect of light and moisture of earlier arrivals.

markedly gregarious.

53. This plant is perennial and as a rule

T'he plant consists of a much branched rhizome which constantly extends centrifugally outwards in all directions.

The aerial culms are biennial and are either produced from the apex of the rhizome branches or they arise as axillary shoots from the basal nodes of older culms, close to or below the ground surface.

The culms are situated close together, the entire plant thus forming a well-defined clump or tuft, with the oldest culms in the interior and the youngest at the periphery. The latter as already noted is constantly extending outwards as the young culms continually develop from the buds of the rhizome or from the base of older culms. ${ }^{1}$

The period of comparatively vigorous vegetative activity is approximately 10 months from February to November. It usually flowers in October and the grain ripens in November.

If a clump of this plant is examined in December-January it will as a rule be found to contain-

(i) A number of old dead culms which completed their life-cycle in the preceding Uctober-November.

(ii) A number of immature culms bearing green leaves in which the culm proper is as yet very short.

Owing to the very short internodes on these inmature culms and to the leaf-insertions being in consequence crowded close together each such culm resembles a tuft of leaves.

\footnotetext{
1 During the eold, or hot season, in areas which have been recently burnt the position of the youngest eulms at the periphery can be very clearly seen, as a ring of young green shonts then surrounds the blackened stumps of the old culms in the centre of the clumps which have been burnt.
} 
These culms vary in size from the largest which have had the benefit of a complete season of regetative activity to the young buds which commenced their development towards the close of the season of vigorous growth in September-November.

If one of the larger of these shoots is looked at more closely it will be found to consist of a short hard basal portion of mature culm measuring usually $1-2$ inches in length and with as a rule $12(9-16)$ short internodes which are clcarly defined by the insertions of the leaves. The lcaves inserted on the nodes of this piece of culm are more or less dead and withered and can be readily stripped from the nodes of the hard culm on which they are inserted. Inside these we find one or two not yet fully developed green leaves and finally in the centre is the terminal growing point of the culm situatcd about $0 \cdot 25$ inch about the upper node of the mature basal portion of the culm.

The first two leaves produced at the extreme base of the culm are scales, or at all events, have no obvious green lamina and omitting these it will be seen that the short piece of culm matured during the first season's growth carries, as a rule, 10 leaves. Growth is resumed with more or less vigour in February and towards the end of that month young culms may often be found in which the apical bud of the culm has been raised some 3 inches above the surface of the ground owing to the growth and elongation of the upper immature internodes. Towards the end of April culms have been collected in which all the internodes of the flowering culm can even then be clearly distinguished and in which the apical bud has been raised 8-9 inches above the ground by the elongation of these internodes. It is interesting to note also that this vigorous growth is taking place at a period when the rainfall is very scanty.

The total number of long internodes developed in the flowering culm is usually 10 , excluding the apical segment which terminates in the panicle. Thus we have here each year an apparently constant average rate of growth corresponding to a single leaf for each month of the season of vigorous growth from February-November.

As an average culm which dies after flowering thus persists through two growing seasons the culms may be described as biennial. No case has been seen in which a flowering culm has been produced in one season and the time of flowering is as a rule very constant. ${ }^{1}$ At the same time the exact period which an individual culm takes to complete its cycle varies, owing to the fact that young culms may commence their development at any time during the period of vegetative activity. For this reason also if a clump is examincd in the season of rest, the immature culms are found to vary in age and size from young buds which have recently commenced development to the cuims of one full season's growth.

An exceptionai type of development is very frequently seen in this species as follows.

After the usual number of short basal internodes which as a rule immediately precede the production of the long internodes of the flowering culm, only a few long internodes are found and then a second series of short internodes, after which follow the long internodes

1 Rare cases of culms of this species and also of Erianthus Ravenne flowering in November, December and .Jannary liave licen met with which indicate that undcr exceptional circumstances these species are capable of vigorous growth practically tluroughout the year. 
of the flowering culm proper. The basal series of short internodes in a normal culm is proinced as a rule close to the ground surface, the initial long internodes of the flowering culm being well above the ground. In the exceptional case noted above, however, the first series of short internodes is deep below the ground, the second series is just below the surface, while vigorous roots are developed from this second series and from the long internodes below it.

The clumps of this species, which is usually found on alluvial soil in, or close to, the beds of water-courses, are particularly liable to be inore or less covered by masses of sand, or débris, brought down by floods in the rains and this is apparently the cause of the abnorinal development noted above.

At the beginning of the rains, the basal long internodes of the flowering culm have, as a rule, already completed their growth, but when these are covered with soil or débris, vigorous roots are developed from their nodes and this appears to check the development of the flowering culm and to result in the production of a second series of several short internodes near the surface of the ground, after which the normal long internodes of the flowering culm may be produced the same season, or this may be deferred to the next growing season. In the latter case the culm persists for three seasons.

If, when the change of soil level takes place, the flowering culm has so far developed that some mature long internodes are still left uncovered, although roots are produced by the submerged nodes, there is no development of a second series of short internodes, or check in the growth of the flowering culm as noted above.

Exceptional development is also frequently caused by the fact that the leaves of this species are largeiy cut and used for thatching. For this purpose the immature leafy culms of the first season are cut over at a height of 1 to 2 feet above the ground. This operation does not damage the low-seated apex of the culm itself, but results in the more or less complete destruction of the upper green leaves which, in ordinary course, would have nourished the long internodes of the flowering culm next season. Instead of long internodes and the flowering panicle being developed next season therefore, such a damaged culm only produces a second series of some 10 short internodes, while the production of the long internodes of the flowering culm is deferred to the third season. In such cases therefore the culm persists for three instead of two seasons and the base of the flowering culm shorvs about 22 short internodes at the base, aggregating 2-4 inches in length, instead of the usual 12 short internodes aggregating $1-2$ inches. In areas where this grass is cut for thatching purposes it has been noticed that there is frequently a marked periodicity in fowering, an unusually large number of flowering culms being produced in one year, while the next year very few or no culms flower. The cutting is usually done in October-January and it is clear that during the following rains each clump will contain (1) the culms which were cut over and which are developing a second series of short basal internodes in consequence, (2) the young culms which are in their first season. None of these will ordinarily flower that year but next year both (1) and (2), if they are not further damaged or [ 74 ] 
interfered with, will flower and the clump will thus contain double the usual number of flowering culms. A natural result of the presence of this unusual number of large old culms is that less light is available for the healthy development of young culms of the current season, of which therefore an unusually small number are produced. The natural result is again an unusually small proportion of flowering culms the following year.

As the commercial munj is only obtained from the upper leaf-sheaths of the flowering culm, it would appear from the above that the areas worked for thatching grass and munj should be kept distinct, in the former the grass should be cut over annually towards the close of the season of vigorous growth and in the latter, damage to the leaves, by cutting or otherwise, should be avoided as far as possible.

The mode of growth and development of the culms in Erianthus Ravennce is practically identical to that described above except that the basal scales are usually four in number. In old chumps of Erianthus, however, it has been noticed that the culms which originate from the buds of the rhizome frequently show an average of 20 short basal internodes measuring 2-4 inches and süch culms apparently persist for three years, whereas the axillary culms which originate at a higher level show the normal development.

It is believed that such shoots commence their development at the break of the rains in June, whereas the average shoot starts vigorous growth in February. This is possibly on account of insufficient light being available, until the old dead leaves in the clump have been beaten down by the rain and are more or less decayed. During the first season such a shoot would be expected to show ten short internodes (four with scales and six with leaves for the period June-November). During the second year, owing to the upper leaves reaching a considerable height in the clump, activity might commence in February and an additional 10 short internodes might result for the period February-November. The flowering culms eventually produced in the third season from these long persistent bases usually show unusual vigour both as regards diameter, length and number of long internodes. It is believed that similar development occurs in S. Munja.

54. The remarks given under this head for SusceptibilS. Narenga below apply also to this species as regards the kind of damage done by fire. ity to Fire. The present species however is far more liable to severe injury than $S$. Narenga from both early and late fires for the following reasons :-

(a) It usually occurs on sandy soil. In areas which are burnt, the rain washes away such soil from the base of the clumps, more or less exposing the base of the culms and the rhizome branches from which the young culms are developed. Such soil also rapidly dries after the rains and the base of the clumps, which as noted above are more or less exposed to the sun and wind, also become dry, as do the dead leaves and débris contained in the clump. There is therefore a far greater danger of the fire penctrating to the base of the clump and destroying not only the first year culms, but also the rhizome itself. On loam 
fire damage is greatly diminished and an early fire is often almost innocuous on such soil.

(b) Owing to vegetative activity being fairly vigorous in February, the growing points of the young culms, commencing their second season's growth, are often 2-3 inches above the ground surface in that month, whereas in S. Narenga they are as a rule still below the surface.

As in S. Varenga, the shoots which are most subject to fire damage are the one year culms which, in the ordinary course, would produce the long, flowering culm and panicle the following season. Thai early fires on sandy soil are capable of destroying these culms and thus of greatly diminishing the production of flowering culms (and consequently of the commercial munj fibre) has been observed again and again. Clumps recently burnt have been examined in the field and the terminal buds of the one year culms frequently found to be brown, discoloured and obviously damaged, while unburnt areas can often be at once distinguished in the forest from adjacent burnt areas owing to the far more numerous flowering culms in the former. This is most marked in November-December before the grass is fired and when the green areas which are annually burnt are sharply defined from the adjacent umburnt tracts which resemble a white sea on account of the multitudes of flufiy panicles.

Cases however do occur where occasional firing is apparently beneficial.

Mention has been made above of the fact that where the leaves of this grass are cut for thatching purposes, the clumps, which are occasionally and not regularly cut, frequently show congested growth and a very poor production of vigorous young culms, owing to the presence of an unusually large number of flowering culms, the leaves of which prevent the young culms at the base of the clump obtaining sufficient light for their development. The burning of such clumps which contain an excess of old flowering culms, results in more or less effectually cleaning the clump of the dead leaves, old culms and débris and is frequently followed by a very vigorous production of young culms during the next season. In this way occasional burning in areas worked for thatching grass is probably beneficial, but the most satisfactory treatment for such areas probably consists in endeavouring to prevent the production of flowering culms and to obviate the necessity for firing by cutting over the immature leafy culms regularly every year. One year culms which are cut over usually produce only leaves and short internodes again during the next season and by continuing to cut these at a suitable height it should be possible to prevent the production of flowering culms.

Intentional burning should be carried out early in the season before the clumps get too dry, as otherwise there is a danger of the rhizome being destroyed by the intense heat.

Any factor which interferes with the natural outward growth of the clumps and causes the young culms to appear inside the clump and under the shade of older culms, instead of just outside the clump at the periphery, as is naturally the case, also results in a similar cougestion of growth and inferior production of vigorous young culms. Such 
factors may for instance consist in the presence of large rocks in the soil, the proximity of other plants of the same or other species, the hardening of the soil around the clumps by heavy grazing and trampling of cattle and the destruction of the young culms developed from the external rhizome branches by the trampling or browsing of cattle. It is probable that in all such cases of congestion temporary relief would be sccured by firing, but this would be of no permanent utility.

It is obvious that a clump which has becn well burnt onc year would be cleared of débris and would probably liave most of the one ycar culms also destroyed. Next year therefore we should expect the clump to consist chiefly of immature leafy culms and the only inflammable material in the clump would consist of the old leaves at the base of these culms, whilc there would be a quantity of green leaves. Such a clump therefore would not burn well and it is a frequent experience in burnt areas that a year in which the clumps burn well is followed by one in which they burn with difficulty. The greater the accumulation of dry flowcring culms the more injurious the fire is likely to be and it is probable that on fire lines the plants would be most injured and weakened if they were cut over for thatching grass every third year. The second year after such cutting there would ordinarily be twice the usual number of dead flowering culms in the clumps.

55. The above remarks on fire damage as regards this specics may be summarised as below :-

(a) Fire damage results chiefly in the destruction of the one year culms and in diminishing the production of the commcrcial munj fibre. It is however often sufficiently severe to damage the rhizome branches and may thus kill the plants cutireiy.

(b) The damage done is undoubtedly most severe on sandy soil and on loam the damage done by an early fire is as a rule insignificant.

(c) The later in the season the fire occurs the more severe the damage, owing to the greater dryness of the dead leaves and débris in the clump.

(d) Areas requircd for the production of munj should be carefully protectcd from fire especially if on sandy soil, and also from damage to the leaves by grasscutting, grazing or otherwise.

(e) Areas worked for thatching grass should be kept distinct from those requircd for munj.

In such areas the grass should be cut annually to diminish as far as possible the production of flowering culms and if heavy flowering does occasionally occur the clumps should be burnt early in the season. The soil around the clumps should be kept loose to allow of the free growtl outwards of the rhizome and to prevent the young culms and ends of the rhizome branches being situated close to the inflammable material inside the clump. ${ }^{1}$

\footnotetext{
${ }^{1}$ The mode of development of the clumps and culms and the occurrence of congested growth in this and other chosely alliel species of Saccharum and Erianthus have many points in common with what is seen to obtain in tufted species of Bamboo, as will be seen by a reference to a most interesting paper by Mr. W. H. Lovegrove on Deadrocula nus st:ictus in the India $\iota F o r e s t e r$ Tolume IX T'I, p. 433.
} 
Viility as

Fotder and luest Treatnent f'or

Fodhler

Production.

Relations of

Grassland to

Iroonlanl.
56. This plant is as a rule not much utilised for fodder and cattle only eat the young and immature leaves. Grasslands required for grazing should be fired so that the young leaves may become available in the hot season.

57. On areas where this grass is dominant the soil and moisture conditions are as a rule only suitable for dry miscellaneous forest, as a fair representative of which we may take the woodlands of khair, Acacia Catechu. The latter has been seen to obtain a footing and effectually oust $S$. Munja from areas where the latter had first occupied the ground and become the dominant species.

A plant which frequentiy occurs with this grass is Zizyphus Jujuba and on areas which are regularly fired and heavily grazed throughout the year, the latter tends to become dominant. In such areas the Saccharum is unable to develop, the young shoots being srazed down by the cattle with the exception of the few culms which are able to develop under the protection of the Zizyphus. The latter however is able to persist although the repeated grazing and fire damage prevents the plant becoming more than a shrub. The seed of the Zizyphus is largely distributed by jackals and Mr. P. H. Clutterbuck has pointed out that the latter tend to frequent grazing areas, they being followers of the larger beasts of prey and aiso attracted by the carcases of cattle which happen to die, and this circumstance probably favours the rapid extension of the Zizyphus in such areas.

\section{D.-Economic Uses.}

58. This species is of great commercial value and is probably most widely known on account of the valuable fibre (called munj) extracted from the upper leaf-sheaths of the flowering culm, which is used for cordage, mats, etc. For this purpose, as a rule, only the two uppermost leaves of the culm are utilised, as these have the longest sheaths. In an average culm measuring $17^{\prime} 3^{\prime \prime}$, the topmost sheath measured $3^{\prime} 10^{\prime \prime}$, the next below was $2^{\prime} 11^{\prime \prime}$ and the next $2^{\prime} 1^{\prime \prime}$ which indicates how the length of the lower sheaths diminishes.

Watt writes as follows regarding this fibre:- "The much prized munj is strong, elastic and has a wonderful power of enduring moisture without decaying. It is extensively employed in the manufacture of cordage, ropes, the famed Delhi mats, and in the preparation of baskets, etc. Munj mats * * are largely produced in Allahabad, Agra, Delhi, and are traded in all over India, and within recent years have begun to find their way to Europe."

The thin upper portion of the flowering culm is locally called sirki and is used for making winnowing trays, cart-covers, etc. The thick lower portion of the culm is locally called bind and is used in place of split bamboos for making screens (tatties) and in thatching.

1 Commercial Prcducts of Ir dia by Sir George Watt, 1؟08, p. 930.

$\left[\begin{array}{ll}78 & ]\end{array}\right.$ 
The leaves are largely used for thatching and also constitute a valuable paper matırial.

Mr. William Raitt, the paper expert, in an article dealing with the relative value of possible paper materials alludes to this grass as follows :-

"It is impossible to deal at length with all the fibrous grasses known, but as types of the elasses most worthy of attention we may refer to three species which have already proved of value for paper-making.

Muriz (Saccharum Sara)—a reed-like grass found on chur and waste lands in Northern India. Very gregarious in habit, growing in dense thicket-like masses, which can be eut and collected at low cost. Being generally found in the neighbourhood of rivers, the economie radius of colleetion is widened by the possibilities of water transport. Yields an excellent, easily bleached pulp, similar to that of wheat straw."1

This species also has eonsiderable value on aecount of its power of fixing unstabls soil and of preventing the drifting of sand. It is not infrequentiy found in stream beds where it has suecessfully resisted the foree of the water, each elump forming a nucleus for the aecumulation of sand and débris.

Duthie writes as follows on this point: "At Jeypur it is extensively used as a sandbinding plant; and the experiments which have been undertaken there for arresting the movement of sand prove it to be very suitable for the purpose."'

Saccharum Narenga, Wallich ex Hackel in Monogr. Androp. (1889), p. 119. (Plates XII and XXIII-XXV.)

Syn. Saccharum porphyrocomum, Haekel, l.c., p. 120.

? Saccharum exaltatum, Roxb., l.c., 245.

F. B. I., VII, 120; H., 119.

References.

P., II, 1188.

The Sub-Himalayan traet from Dehra Dun to Assam, Bengal, Central India and Distribution. Burma. Extends to China.

\section{A.-Description.}

Kanwal (Dehra Dun), Bata (Goalpara, Assam), Barota (Sibsagar, Assam).

Ereet, attains a height of $16 \mathrm{ft}$. and diameter of 0.5 in. Solid.

Vernaeular

Name.

Quite smooth and polished except immediately below the leaf insertions and the base of the paniele, where it is densely bearded with long adpressed white hairs.

Covered with bulbous based hairs, especially towards the apex; the hairs easily break Lap-sheatl. off and old sheaths are often rough with their persistent bases.

1 Tropical Agriculturist, Vol. XxxIII, July 1909, pp. 10--12.

2 Fodder Grasses of Northern India by J. F. Duthie, p. 25.

$\left[\begin{array}{lll} & \tau & \end{array}\right]$ 
Lower sheaths are longer, upper sheaths are shorter than the proper internodes.

Of uppermost leaf of flowering culm from mucroniform, 0.25 in. long, to linear, $14 \mathrm{in}$. long and $0.25 \mathrm{in}$. wide. white.

Of lower leaves, attains a length of $6 \mathrm{ft}$. and width of $1 \mathrm{in}$. Colour dark green, midrib

Greatest width usually about the middle. Apex long acuminate, base narrow anc flat.

In basal leaves midrib occupies $\frac{1}{2}$, or less, of the width of lamina at base.

Margin scabrid except at extreme base.

Bulbous hairs scattered chiefly on upper surface towards the apex.

Densely bearded above immediately behind the ligule.

ulgule. Membranous, rounded, up to $0.25 \mathrm{in}$. high.

Ciliate and minutely silky dorsally.

Intlorescence. Spikelets in pairs, one pedicelled and one sessile on the capillary iointed branches and branchlets of a terminal panicle.

Primary rachis yellow, sulcate, hairy on ridges, bearded at nodes.

Primary branches sub-verticillate.

Flowering panicle 9 in. to 2 ft. long, narrow, lanceolate to sub-cylindric; branches horizontal or slightly ascending, simple, or sometimes branched at base; colour purplishbrown.

Fruiting panicle purple, branches closely adpressed to rachis and very fragile.

Splkelots.

Awnless, oblong, 0.08 to $0 \cdot 13 \mathrm{in}$. long.

Sessile and pedicelled similar, each one-flowered and $\bar{\phi}$.

Pedicelled spikelet at length falling from the pedicel, sessile falling with the attached pedicel and joint of axis. The pedicelled spikelets usually fall first and the sessile follow later.

Joint of axis 3 -gonous, sparsely hairy on angles, $\frac{1}{2}$ to $1 \frac{1}{2}$ the sessile spikelet but usually shorter than to subequal the spikelet.

Pedicels glabrous or hairy on margins, $\frac{1}{2}$ to $\frac{3}{4}$ sessile spikelet. Majority of pedicels shorter than to subequal the proper joint.

Callus hairs stiff, usually purple, shorter or a little longer than the spikelet.

Glume I.-Oblong to oblong-lanceolate, brown, coriadzous, apex sub-acute, obtuse or minutely bi-dentate.

With two lateral keels; $2-7$ nerved.

Margins inflexed, ciliate.

Dorsally flat between the keels, hairy or smooth below, puberulous above. Villi not overtopping the glume. 
Glume II.-Subequal I. Oblong to oblong-lanceolate, brown, thinly coriaceous, apex membranous, sub-acute or obtuse.

A central keel, $3-5$ nerved.

Margins inflexed, ciliate.

Dorsally giabrous or hairy below, puberulous above. Villi not overtopping the glume.

Glume III.-Subequal I. Oblong, hyaline, enerved, or with one or more partial basal nerves, ciliate.

Glume IV.-Similar to III, but slightly shorter, enerved or with a partial median nerve.

Pale $-\frac{1}{4}$ to $\frac{1}{2}$ IV, ovate to oblong, hyaline, enerved, ciliate.

Lodicules, two, cuneate, glabrous, 0.02 in.

Anthers, three, $0.05-0.09 \mathrm{in}$. long, yellow or more or less spotted with purple.

Stigmas, two, $0 \cdot 03-0 \cdot 04$ in. long, dark purple.

The hairy leaf-sheaths, the culms bearded at the leaf insertions, the narrow, purple, Field characvery fragile, fruiting panicle and the dark grcen leaves readily distinguish this species in ters. thie field.

\section{B.-Taxonomy.}

59. Hackel divides the genus Saccharum

into four sub-genera, two of which contain all the Indian species.

These two sub-genera (sections) have been adopted in the F. B. I. as follows :-

I. Eusaccharum.-Rachis of spike (Hack. raceme) fragile. Spikelets of each pair subequal, sessile and pedicelled, both fertile (Hack. $\$$ ). Stem solid.

II. Sclerostachya.-Rachis of spike tenacious. Both spikelets of each pair pedicelled. Stem fistular.

Hackel places only one Indian species in the latter, viz.-

S. fuscum Roxb. This is adopted in F. B. I. where a second Malayan species is also added, viz. S. Ridleyi which Hackel described after the publication of his monograph.

The characters of the culm being fistular or solid and the rachis tenacious or fragile are therefore seen to be of sectional rather than specific value.

The flowering culms of the present species are very subject to damage by insects and fungi. Culms which have been thus injurcd usually show a small perforation which is apparently caused by some sucking insect, while the tissue of the culm in the neighbourhood of the hole becomes discoloured and usually reddish giving the appearance of the "redrot" of the Sugarcane.

Specimens of the damaged culms were submitted to Dr. Butler, Imperial Mycologist at Pusa, but although fungal hyphæ were found in the discoloured tissue these apparently belonged to a saprophytic species, as no parasitic fungus could be isolated on incubation. 
The question as to whether, or not, a sucking insect is invariably the primary cause of the injury however requires further investigation.

The injury is most frequentily found at the leaf insertions where the insect, or fungus, probably intercepts the food materials on their way from the leaf into the culm. This interference with the normal nutrition of the culm results in the internode next above the attacked leaf-insertion becoming fistular instead of solid and being unusually small, weak and more or less imperfectly nourished. When the internode is much weakened in this way it is frequently unable to withstand the action of the wind and the upper portion of the culm, with the terminal panicle, then bends over, but usually still remains attached to the plant. Such a culm looks as if it had been half-broken by a passer-by. The panicle branches also of culms injured in this way are remarkably tenacious and the spikelets are persistent. Such a panicle therefore forms a striking contrast to a normally matured panicle and has a characteristic and distinctive appearance both when seen in the forest and in the herbarium. The normally-matured panicle shows a persistent main rachis with closely adpressed fragile branches which rapidly break up and fall off, the pedicelled spikelets falling first from their pedicels and the sessile spikelets following with the joints of the branches and branchlets, while, so long as the spikelets remain, the callus hairs give the panicle a purple colour. The abnormal panicle, on the other hand, shows persistent and often spreading branches and porsistent spikelets, while the callus hairs are frequently pale to almost white and thus give the panicle a pale, or brownish, feathery appearance. See Plate XXIII, fig. 3, and compare with the normal panicles shown in fig. 2.

In these abnormal flowering culms of this species therefore we have a combination of two remarkable and important characters, viz. the fistular culm and tenacious rachis of the panicle branches, and the writer has seen panicles of this description placed under $S$. fuscum Roxb. ${ }^{1}$ in herbaria. The latter species, however, apart from other characters, can be at once distinguished by the fact that both spikelets at each node are clearly pedicelled and the spikelets eventually fall off from the tips of the pedicels, leaving the persistent panicle branches intact, a state of affairs which is not seen in the abnormal panicles noted above. Sez Plate XXV, fig. 11.

Whereas the spikelets of a normally-matured panicle of the present species contain the normal fully-formed fruit (grain), those of the abnormal panicles either contain a very small and imperfectly developed fruit, or else the entire unexpanded flower with ovary and stamens, thus indicating that the development of the flower and fruit has been prematurely checked.

The glumes of these abnormal panicles show no marked peculiarity. Saccharum porphyrocomum, Hackel, is founded on No. 19285 Herbarium H. F. Hance. The type is in the Herbarium of the British Museum and has been examined by the writer. It consists

1 In F. B. I. Saccharum fuscum Roxb. is said to occur in the upper and lower Gangetic Plains, and Duthie (Fcdder Grasses of Northern India, 1888, p. 23), says that it occurs "in the plains of Northern India * * * usually in damp spots." The writer ha at jresent no personal knowledge of this species in the field, and the only specimens in Herbarium Eehra are from Assam. Specimens and information regarding this grass will be welcome at Dehra Dun. 
of abnormal panicles of Saccharum Narenga which owe their peculiarities of a fistular $c u l m$ and persistent panicle branches to some injury similar to that described above. This species therefore cannot be maintained.

It is noticeable that the injurious action of the insect, or fungus, or both, dcscribed above can to some extent be imitated artificially. On a plant growing in the experimental garden at Dehra Dun one of the flowering culms was sharply bent over and left hanging on the plant on October 20th, 1909. It was thought that this might intcrfere to some extent with the passage of water and food materials to the panicle and thus more or less produce the results mentioned above. The panicle which was treated in this way dic show the persistent branches and general appearance of those already described but the culm did not become fistular, probably owing to the central tissue having been fully developed when the culm was bent.

Plate XXIII, fig. 2, shows the panicle treated as above described and three other normal panicles, all four of these having bieen picked from the same plant on November 20th, 1909. The panicle from the bent culm clearly shows the persistent branches.

It must be noted that culms are sometimes found in the forest which have been more or less damaged by insects, or fungi, or both, but which do not show the abnormal characters noted above, and the extent to which the culm and panicle are affected appears to depend on the state of development of the culm when it is attacked and on the severity of the attack. In no case, however, has an abnormal flowering culm, exhibiting the characters described above, been found which had not been more or less severely damaged, while both abnormal and normal culms have frequently been collected from the same plant.

It must also be noted that the flowering culms of this species and also those of Saccharum Munja and Erianthus Ravennce are frequently attacked by larvæ which hollow out the culms and this also often results in the premature drying of the panicle but this kind of damage obviously differs from that described above in which no obvious excreta or other signs of larval damage are seen. Hackel divides the present species into two varieties as below :-

a genuinum Glumes I and II of sessile spikelet obtuse, glabrous dorsally.

I sub-enerved with the exception of the keel nerves.

Sessile spikelet $2 \cdot 5$ to $3 \mathrm{~mm}$. $\left(0 \cdot 1^{\prime \prime}-0 \cdot 12^{\prime \prime}\right)$ long.

Tropical Himalaya.

$\beta$ Khasianum Glumes I and II of sessile spikelet sub-acute, dorsally hairy below. I faintly 3 nervid in addition to the keel norves.

Spikelets larger $3.5 \mathrm{~mm}$. $\left(0 \cdot 14^{\prime \prime}\right)$ long. Khasi Hills.

The writer finds it impossible to follow this classification. In the first place it must be noted that in dried specimens the hairs easily break off from the hard coriaceous giumes, especially in mature spikelets, and leave no obvious scar. It is not therefore always easy to determine the degree of hairiness of the glumes from herbarium specimens. In all the fresh flowering spikelets collected by the writer in Dehra Dun, however, there is an obvious. 
difference in the hairiness of glumes I and II respectively. Thus in the sessile spikelet, while glume I was more or less densely hairy dorsally, glume II was glabrous, and while glume II of the pedicelled spikelet was often dorsally hairy it was usually less hairy than I. At the same time the hairiness of even glume II of sessile spikelet appears to have little constancy, geographical or otherwise.

In fourteen panicles, for instance, which were kindly sent me by Rai Sahib Kanjilal from Sibsagar, Assam, only a single panicle (with spikelets $0 \cdot 13$ in. long) showed the hairy glume II of Khasianum and on this panicle glume II of sessile spikelet varied from glabrous to fairly densely hairy dorsally.

So far as herbarium specimens are concerned the local Dehra Dun plant shows glume I of sessile spikelet and glumes I and II of pedicelled spikelet varying from glabrous to densely hairy dorsally and a similar variation has been found in panicles received from Sibsagar. This variation also has been observed on one and the same panicle.

Apart, however, from the inconstancy of the hairiness of the glumes, the other characters selected by Hackel for the definition of his varieties are not constant and are not necessarily correlated. Thus, on one and the same panicle, glume I of sessile spikelet has been found to vary as regards its apex from sub-acute to obtuse, and as regards its nervation from sub-enerved to clearly 1-3 nerved in addition to the keels. The length of the sessile spikelet also has varied from $0 \cdot 1$ in. to $0 \cdot 13$ in. on one and the same panicle, while spikelets $0 \cdot 13 \mathrm{in.}$ long have shown the hairy glume II of Khasianum.

\section{C.-Biological and CEcological Notes.}

Habitat. widely distributed savannah grass of Sal forests and is usually the dominant species, at all events at first, in areas from which the Sal forest has been cleared.

It is found in this locality on well drained loam, usually with a considerable admixture of humus. Like Erianthus Ravennce it has considerable power of withstanding shade, but requires considerably less moisture than that species.

Compared with Saccharum Munja, this species is a much stronger shade-bearer and slightly less sensitive as regards good soil aeration. It requires for its vigorous development a soil with a greater capacity for retaining moisture and not so subject to rapid drying, as compared with that which suffices for healthy development of S. Munja.

As already noted it is usually found on soils which have been long under forest and which have a considerable admixture of humus.

In this locality the species is found at its best in small shady blanks in Sal forest, and it is here a valuable indicator ef soil and moisture conditions suitable for Sal.

Development of Culms, Season of Vegetative Flowering.
61. Perennial, usually gregarious.

The plant consists of a much branched rhizome which constantly extends outwards on all sides in a centrifugal direction. The aerial culms are biennial and are either the direct [84. $]$ 
continuation of the growing points of the rhizome, or they arise as axillary shoots from the basal nodes of older culms.

The culms are situated close together, the entire plant thus forming a clump or tuft, the oldest culms being in the interior of the clump while the youngest culms are situated at the periphery which constantly extends outwards. In some cases the tufts are not clearly defined and the plant shows a somewhat spreading habit.

This grass occurs in comparatively moist localities but its usual period of vigorous vegetative activity is about 6 months from June to November, it flowers in OctoberNovember.

At the end of the first season's growth the culm is found to consist of a short, hard, mature, basal portion measuring 1-2 inches in length and consisting of 8-12 (usually 10) very short internodes, which are clearly defined by the insertions of the outer older leaves.

These outer leaves are more or less dead and dry, while within and above them is situated the still soft immature apical portion of the culm, carrying one or two undeveloped green leaves, and still younger leaf rudiments, terminating in the apical growing point of the culm.

Such a culm therefore appears to be mercly a tuft of large leaves.

During the second season of vigorous growth the immature apical portion of the culm develops with great rapidity and produces 5-7 (usually 6) long internodes and finally an apical segment which terminates in the flowering panicle. Thus the entire length of the culm, which may attain a height of 16 feet, with the exception of the basal length of some 2 inches, is developed in a single growing season.

It should be noticed that as a rule the 3 or 4 leaves which are first produced at the extreme base of a young culm are mere scales with a very minute, if any, lamina and, omitting these, the mature piece of culm usually developed in the first season carries 6 leaves. This again is the number of leaves carried on the 6 long internodes of the flowering culm, so that we have in each year an apparently constant rate of growth corresponding to a single leaf for each month of the vegetative season June to November. The culm dies after producing flowers and seed and as it thus persists through two complete growing seasons, it may be described as biennial, but it must be understood that a culm does not necessarily persist for exactly 2 years.

The young culms may commence their growth at any time during the period of vegetative activity and a culm which first appears in June 1908 will have completed its first year in June 1909, and will flower and complete its cycle in October-November 1909, i.e. in about $1 \frac{1}{2}$ years. Another culm which originates, say, in September 1908, would ordinarily flower in October-November 1910, i.e. would complete its cycle in about 2 years and 2 months. Again a culm which originates in August 1908, if growing under favourable circumstances, might flower in November 1909, i.e. in 16 months. In no case, however, has a flowering culm been found to be produced in a single growing season and the 
normal rate of growth is, as noted above, 10 short internodes the first season, with 6 long internodes and the panicle the second season. The season of flowering is also very constant.

Exceptions of course occur and some flowering culms may be found with 20, and sometimes even more, short basal internodes, thus apparently indicating that they have persisted for at least 3 seasons.

Such cases however appear to be undoubtedly abnormal and are probably due to exceptionally unfavourable conditions of light, competition by neighbouring shoots, damage by insects, fungi, and so on. In some of these cases periods of normal development are found to be succeeded by periods of exceptionally feeble growth and these are almost certainly caused by damage to the leaves by grazing, fire, or grass-cutting.

susceptibility to Fire Damage.

62. During the cold and beginning of the hot season, when the forest grasslands are chiefly exposed to fire damage, the aerial portion of this species consists of-

(a) The dead flowering culms.

(b) The immature short leafy culms which vary in size from those which have enjoyed a full season of vegetative activity to the young buds which have only recently commenced development.

The flowering culms are, as already noted, situated in the interior of the clump and the young leafy culms at the periphery. In old plants, also, there is usually a more or less considerable hollow space in the centre caused by the disappearance of previous generaticus of flowering culms and in fire-protected areas this space is more or less filled with dead leaves and inflammable débris.

The shoots which are most exposed to damage are the one year culms which carry on their lower internodes a number of large, more or less dry and inflammable, leaves and which are situated in the immediate neighbourhood of the dead flowering culms and any débris which may have collected in the interior of the clump. The youngest culms on the other hand carry far less inflammable material and are situated on the exterior of the clump, while the terminal buds of the branches of the rhizome are on the extreme outer periphery, protected by hard scale-like leaves and as a rule below the growth surface. See Plate XXV, fig. 15.

The principal cause responsible for mitigating the damage done by fire to this species in this locality appears to be the fact that it occurs in comparatively moist soil with a considerable admixture of clay. Owing to its compact nature the soil resists the denuding action of rain and effectually protects the buds of the rhizome branches and also to a great extent the base of the one year culms, the apex of which is usually situated below the surface.

An early fire, therefore, as a rule does very little direct damage and is generally not sufficient to prevent the production of flower and seed, as would be the case if the apical bud of the one year culms was destroyed. On fire-lines and small grasslands where the soil is more or less sheltered by the adjacent trees and thus kept moist, and also in large

$$
\left[\begin{array}{ll}
-8 & 86
\end{array}\right]
$$


grasslands where the soil is well supplied with moisture, the damage done by fire is practically nil.

In exposed grasslands, such as Gola Tappar (see Plate XL), however, which are regularly fired and where the soil is comparatively dry, this species, although flowering fairly freely, shows inferior dimensions, but this appears to be due rather to the want of sufficient moisture in the soil for vigorous growth, caused mainly by the destruction of all humus and organic débris by the fire, rather than to any direct injury by fire. No case has yet been seen where fire alone has sufficed to exterminate this species.

As a general rule the later the fire occurs in the season and the drier the locality, the more severe will the damage be, and a fire occurring in an area long protected from fire will be more injurious than a fire in an area periodically burnt, owing to the accumulation of débris in the clumps.

63. This plant is generally considered of ctility as little or no value for fodder and cattle only eat the young and immature leaves. Grass- west Treatlands required for grazing therefore should be fired, so that the young leaves may become mont for $\mathbf{P r}_{\mathbf{r} 0 \text { - }}$ available for fodder in the hot season.

duction.

On areas which are annually burnt and then grazed the production of flowering culms is to some extent diminished.

indicator of soil and moisture conditions suitable for Sal.

64. As noted above, this species is a valuable Relations of Grassland to Woodland.

\section{D.-Economic Uses.}

65. The culms and leaves are used for thatch-

ing, for making tatties (=screens), etc.

Frianthus Ravennae, Beauv. (Plates VIII, XXVII.)

F. B. I., VII, 121; H., 139.

heferenees.

C., II, 949.

Western Himalaya, Punjab, Upper Gangetic Plain, Sindh. Extends westwards to the Distrilution. Mediterranean.

\section{A.-Description.}

Dolsar, dolu (Dehra Dun).

Erect, attains a height of $19 \mathrm{ft}$. and diameter $0.7 \mathrm{in}$.

Vernaeular

Name.

Solid, often slightly fistular just below the panicle. Smooth and polished, striate.

Shortly and finely bearded at the leaf-insertions.

Hirsute with bulbous-based hairs, the latter varying in colour from white to yellow or Leaf-sheath. brown. 
The hairs are more or less deciduous and old sheaths are often rough with the persistent bulbous bases.

Upper sheaths glabrescent.

Always longer than the proper internode.

Long ciliate on margins towards the apex.

Of uppermost leaf of flowering culm from $8 \mathrm{in}$. long and $0.25 \mathrm{in}$. wide, linear and tapering from base, to $2 \frac{1}{2} \mathrm{ft}$. long and $0 \cdot 65$ in. wide with greatest width about the middle.

Lower leaves attain a length of $6 \mathrm{ft}$. and width of $1 \frac{1}{2} \mathrm{in}$. Are usually $4-5 \mathrm{ft}$. long and 1 in. wide.

Greatest width about the middle, sometimes in upper third.

Dark green, midrib white.

Apex acuminate, narrowed towards the base.

In basal leaves the concave midrib occupies $\frac{1}{2}$ or more of width of lamina at base (often the entire width of the leaf).

Densely villous above towards the base with bulbous-based hairs, more or less scaberulous along nerves, margins scabrid.

Ligule. A narrow membranous rim not exceeding 0.07 in. high. Entire and rounded or deeply 2-lobed, patently hairy dorsally with stiff white hairs.

Ciliate.

Intorescence. Spikelets in pairs, one pedicelled and one sessile on the capillary jointed branchlets of an ample terminal panicle.

Primary rachis sulcate, scabrid on ridges. Primary branches compound subverticillate.

Flowering panicle, 1-3 ft. long, lanceolate, brownish red in colour with spreading branches. Fruiting panicle oblong, dirty white or brown in colour, branches closely adpressed to rachis.

Distinctly awned, lanceolate acuminate.

$0 \cdot 13$ to $0 \cdot 16$ in. long. Exserted part of awn usually about equal to length of spikelet (from $\frac{1}{2}$ to $1 \frac{1}{2}$ times the spikelet).

Sessile and pedicelled similar, each one flowered and $\bar{\phi}$.

Pedicelled spikelet at length falling from the pedicel, sessile falling with the attached nedicel and joint of axis. Joints and pedicels villous with long pale purplish or brownish hairs. Hairs of joint overtop joint by about twice the length of the joint.

Joints $\frac{1}{4}$ to $\frac{2}{3}$ sessile spikelet. Pedicels $\frac{1}{4}$ to $\frac{3}{4}$ sessile spikelet. Majority of pedicels. longer than proper joint.

Callus hairs shorter than to subequal the spikelet, purplish or brownish in colour 


\section{Sessile Spikelet.}

Glume I.-Lanceolate, 2 lateral keels, dorsally flat or depressed between the keels.

Apex 2-mucronulate.

One or both margins incurved.

Dorsally scabrid on keels, otherwise glabrous, or more or less villous dorsally.

Villi not overtopping the glume, or overtopping by less than $\frac{1}{2}$ glume's length.

'Two nerved, sometimes with $1-2$ additional faint nerves between the keels.

Glume II.-Subequal to I. A central keel.

Mucronate.

Margin incurved ciliate.

Dorsally scabrid on keel, otherwise glabrous or more or less villous dorsally.

Villi not overtopping the glume, or overtopping by less than $\frac{1}{4}$ length of glume.

One nerved and sometimes one or two partial lateral nerves.

Glume III.-Slightly shorter than II.

Oblong-lanceolate, hyaline. Apex mucronate or acute.

Glabrous dorsally.

Margin incurved, ciliate above.

One-three nerved.

Glume IV.-Usually $\frac{3}{4}$ III.

Ovate-lanceolate, hyaline.

Margin incurved, ciliate.

Long-awned. Awn $0 \cdot 10$ to $0 \cdot 23 \mathrm{in}$. long.

Three nerved.

Pale.-About $\frac{3}{4}$ IV, ovate-lanceolate, hyaline, glabrous, enerved.

Lodicules, two, cuneate, glabrous.

Anthers, three, $\cdot 05$ to $\cdot 07$ in. long (0.08 to $0 \cdot 10$ in. fide Hackel) yellow, streaked with purple.

Stigmas 03 to 06 in. long. Yellow.

Pedicelled spikelet is similar except that glumes I and II are often strongly three nerved and both glumes I and II are more densely villous dorsally. Villi not overtopping, or overtopping by less than $\frac{1}{2}$ spikelet's length.

This species is not infrequently mistaken for Saccharum Munja, but is easily distin- Fleld (harac guished by its distinctly awned spikelets, the broader dark green leaves and hairy leaf- ${ }^{\text {ters. }}$ sheaths. The fruiting panicle also is usually browner in colour. 


\section{B.-Taxonomy.}

66. Hackel separates the common Mediterranean form of this plant as a sub-variety (genuinus) with larger spikelets $(0 \cdot 2$ to $0 \cdot 25$ in. long) and with glume IV usually glabrous.

The Indian plant is referred to sub-variety purpurascens.

\section{C.-Biological and Ecological Notes.}

Habitat.

67. This plant, while undoubtedly requiring a liberal supply of available moisture for vigorous development, does not extend into the water-logged soil of the marsh.

It is thus apparently more sensitive as regards soil aeration than Imperata, while it requires far more moisture than either S. Munja or S. Narenga.

It is found on both sandy and clayey loam. Its broad, very thin, dark green leaves are markedly mesophytic, if not indeed hygrophytic in their characteristics, but the plant does not attain the dimensions of the truly hygrophilous species S. arundinaceum.

Warming ${ }^{1}$ states that this species sometimes enters into the composition of reedswamp in Mediterranean countries, accompanied by Phragmites and Arundo Donax.

The plant is a strong shade-bearer, but its capacity in this respect is often masked by the fact that the roots of neighbouring trees and shrubs frequently cause the available moisture supply to fall below that necessary for its vigorous development.

In localities where ample water is available by percolation or otherwise, this plant is seen to be a good shade-bearer.

In this locality it is found at its best on the banks of irrigation channels and watercourses, where ample water is available by percolation and capillarity, but where the soil in contact with its roots is not actually water-logged except for short periods. It usually indicates a soil with the permanent water-table near the surface.

S. Munja above apply, generally, also apply, generally, also to this species. The culms are biennial. The usual period of vegetative activity is from February to November. Flowering takes place in October-November, although panicles are occasionally met with also in DecemberJanuary, thus indicating that activity may in some cases continue practically throughout the year.

During the first season's growth from 1-2 inches of culm is produced with an average of 14 short internodes and carrying 10 green leaves.

During the second season the long internodes (usually 10) of the flowering culm, carrying 10 leaves and terminating in the panicle, are produced. Unlike the Saccharum, however, the leaves of this species are not cut for thatching purposes. 
69. The damage done by fire is similar to that susceptibildescribed above for $S$. Munja and $S$. Narenga, but the species suffers much less than $S$. ity to Fire Munja owing to the fact that it usually occurs on loam. Growth during February also is as a rule not so vigorous as in S. Munja and the growing points of the young clums are usually situated close to the surface of the ground at the end of that month.

70. The leaves of this species are eaten by utility as buffaloes to some extent, especially when young. Grasslands required for grazing should Fodder ant be fired so that the young leaves may become available in the hot season.

inent for

Fodiler Production.

71. On areas where this grass is dominant the Relntions soil and moisture conditions are as a rule suitable for moist mixed forest. Such representa- of Wrassland tive species as Cedrela Toona and Mallotus philippinensis have been seen to be able to naturally establish themselves in areas occupied by this grass without artificial assistance.

The large tufted species of Saccharum, such as S. Munja and S. Narenga, have considerable power of improving the soil by the addition of humus.

Not only do the decaying culms and leaves of these plants themselves add considerably to the humus content of the soil, but the central hollow of the clumps, surrounded as it is by a barricade of culms, acts as a veritable humus-trap in which the leaves and débris from neighbouring trees and plants is caught, stored, allowed to gradually decay and find its way into the soil.

Erianthus Ravennce, being of more robust growth than either of the two species named, possesses this power to an exceptional degree and the writer has removed 11 handfuls of decaying leaves and débris from the centre of a single clump.

\section{D.-Economic Uses.}

72. The leaves of this species quickly decay and are not therefore used for thatching, a point of interest in connection with the hygrophytic character of the species.

The culms are used for making screens, etc.

\section{Imperata arundinacea, Cyrill. (Plates XXVIII to XXX.)}

F. B. I., VII, $106 ;$ H., 92.

P., II, 1188; C., II, 946. higher.

The hotter parts of India and ascending in the Himalayas to $6,500 \mathrm{ft}$. and possibly Distribution.

Extending to the Mediterranean region, Africa, Java, Japan, China, Australia.

\section{A.-Description.}

Siru, sirhu (Dehra Dun). 
culm. Erect, simple, slender, from 5 in. in height and almost filiform, in poorly nourished individuals, to $9 \frac{1}{4} \mathrm{ft}$. high and $0 \cdot 3 \mathrm{in}$. dia.

Solid, slightly fistular at base, smooth.

Leaf insertions tumid, glabrous, or densely bearded with erect white hairs.

Leaf-sheatl.

Glabrous or glabrescent, ciliate or glabrous along the margin towards the apex.

Usually longer than proper internode.

Lamina.

Of uppermost leaf of flowering culm from mucroniform and $0.05 \mathrm{in}$. long to $6 \mathrm{in}$. long and $0 \cdot 25$ in. wide with greatest width in middle.

Of lower leaves erect or arcuate and attains a length of $4 \mathrm{ft}$. and width of $1 \cdot 1 \mathrm{in}$.

Greatest width about the middle.

Dark green, midrib white.

Apex acuminate, narrowed towards the base where the midrib occupies almost the entire width of the leaf.

Smooth, but scabrid on margin and on one or more sub-marginal nerves above, especially towards the apex.

White villous above on margins towards the base and behind the ligule.

Ligule. silky.

Rounded, truncate or two lobed. Attaining a height of $0 \cdot 13$ in. Ciliate. Dorsally

Spikelets in pairs, both pedicelled (one pedicel long and one short), on the simple, or compound, subverticillate, capillary branches of a narrow, spiciform, terminal, panicle. The upper spikelets in the racemes are sometimes solitary.

Branches are tenacious and not jointed.

Primary rachis sulcate, glabrous or scaberulous, sparsely villous at nodes with long white hairs.

Pedicels glabrous, scaberulous or pubescent, and with a few long white hairs towards the base.

Panicle from a little over 1 in. (in depauperate individuals) to $20 \mathrm{in}$. in length, not exceeding 1 in. in width.

Flowering panicle purple with the exserted stigmas, the callus-hairs being closely adpressed to the axis, fruiting panicle silvery white with the wide-spreading callus-hairs.

Not awned, lanceolate, 0.13 to $0.15 \mathrm{in}$. long (attaining 0.2 in. fide Hackel).

Both spikelets of each pair similar, each one-flowered and $\hat{i}$, and at length falling from the pedicel.

Callus-hairs soft, white, $2-3$ times as long as spikelet.

Glume I.-Lanceolate, membranous, slightly thickened towards the base, apex hyaline, 3-9 nerved, none of the nerves extending to apex of glume, margins incurved, ciliate above.

Dorsally villous with soft white hairs overtopping the glume by $1 \frac{1}{2}$ to 3 times the length of the glume. 
Glume 11.-Similar and subequal to I, but sometimes sub-keeled with mid-nerve extending almost to apex.

Glume 11I.-Oblong, hyaline, enerved, apex acute or sub-truncate and laciniate or denticulate, ciliate. $=\frac{1}{2}$ to $\frac{3}{4}$ II.

Glume IV.-Subequal to $\frac{3}{4}$ III, ovate-lanceolate, hyaline, enerved, apex acuminate, acute, or obtuse and laciniate or denticulate, minutely ciliate or glabrous.

Pale--Quacirate, rectangular, or sub-pentagonal, hyaline, enerved, apex denticulate or unequally laciniate, glabrous or ciliate. $\frac{1}{2}$ to subequal IV.

Lodicules.-None, or very minute.

Anthers.-Two, 0.12 in. long, yellow. The filaments are sometimes connate below.

Stigmas.-Two, 0.12 in. long, purple.

The ordinary savannah form of this plant is about $3 \mathrm{ft}$. high and is strongly gregarious. Field CharacWhen in leaf it is somewhat liable to be mistaken for Eragrostis cynosuroides (known in ${ }^{\text {ters. }}$ Dehra Dun by the vernacular name of $d a \dot{b}$ ) with which it is frequently associated and which has a very similar habit.

The leaves of $d a ́ b$ however are broader at the base and glaucous, not dark green like those of sirhu. The old leaves of sirhu also turn reddish or brownish yellow, those of dál are much paler.

The somewhat succulent white stolons of sirhu, also, covered with soft membranous sheaths, are at once distinguished from the hard, polished, yellow stolons of dáb, which are covered with hard shining sheaths.

73. The leaf of the ordinary savannah form Anatomy. of this species exhibits considerable xerophilous adaptations.

The cuticle is strongly developed, particularly in the lower epidermis.

Each longitudinal nerve is provided with two girder-like groups of sclerenchymatous fibres. The girders of the principal nerves are strongly developed and are situated, respectively, close below the upper and above the lower epidermis, the nerve thus being connected with the epidermis above and below. Each nerve is flanked laterally with a narrow band of chlorenchyma, these bands curving inwards and almost meeting around the nerve inside the girders. The chlorenchyma, thus gives the appearance of more or less complete rings around the vascular strands. The epidermis situated immediately above the chlorenchyın is provided with stomata which are particularly numerous on the upper surface of the leaf. Alternating with, and parallel to, the principal nerves on the upper surface of the leaf are longitudinal bands of the remarkable, large, thin-walled, colourless, cells which are called 
motnr-cells by some writers ${ }^{1}$ and bulliform-cells by others. ${ }^{2}$ Beneath these motor-cells, and therefore alternating with the principal longitudinal nerves, are smaller nerves, also provided with girders and chlorenchyma rings, similar to those of the principal nerves, but smaller. Immediately above the midrib is a thick, cushion-like, band of thin-walled colourless cells which is believed to function mainly as water-storing tissue. It is to be noticed that this tissue is protected by a layer of sclerenchyma, one to two cells thick, which lies immediately beneath the upper epidermis, while the bands of motor-cells are provided with. no such protection.

When the leaf dries, the blade becomes convolutely folded inwards towards the upper surface. There seems little doubt that this folding is effected mainly by the shrinking of the motor cells and in a section which has been allowed to dry and fold under the microscope, the leaf tissue on each side of a band of motor cells can be distinctly seen to have been pulled inwards towards the motor cells. This convolute folding of the blade obviously results in the protection of the numerous stomata on the upper surface of the leaf and must therefore considerably reduce transpiration, while the exposed lower surface is protected. by the strongly developed cuticle.

In the marsh form of this plant, the stomata are chiefly on the lower surface of the leaf, thus indicating less nccessity for diminishing transpiration. The fresh leaves are thicker than those of the ordinary savannah form and have a somewhat fleshy, almost spongy, texture. It is remarkable that this is caused mainly by an increase in the size and number of the water conducting vessels of the xylem, annular, pitted and reticulately thickened vessels, with large lumina, being noticeable in the nerves, while there is no marked development of special aerating arrangements, such as large intercellular spaces.

The stolons of the ordinary savannah form show in cross-section, commencing at the exterior, (1) Epidermis with thick cuticle, (2) One to two layers of sub-epidermal sclerenchymatous fibres, (3) A thick sheath of parenchyma, the walls of which turn purple with chlor-zinc-iodine, (4) A small central woody cylinder containing the vascular bundles. This cylinder is protected by an outer layer of thick sclerenchyma, while the bundles are also more or less completely surrounded by sclerenchyma. The walls of the tissue of this inner cylinder all turn dark yellow with chlor-zinc-iodine, with the exception of those of smail areas of parenchyma found chiefly in the centre, which turn purple. ${ }^{3}$ The stolons of the swamp form show an essentially similar structure with the remarkable exception that large air spaces are found in the outer parenchymatous sheath, thus indicating the necessity for special aeration-devices in the subterranean stolons of the swamp form to enable the roots, growing in poorly-aerated water-logged soil, to keep pace with the increased transpiration caused by the enlarged leaf-surface and by the diminished protection of the stomata.

\footnotetext{
I See Grasses by H. Marshall Ward, 1£01, pp. 25, 62.

2 See Brandis in Trans. Linn. Soc. London, Vol. V1I, p. 73.

3 The soft outer parenchymatous sheath (3) is often destroyed by vermin and stolons are often seen in which this sheath has been entirely eaten away, leaving only the central woody cylinder (4) intact.
} 


\section{B.-Taxonomy.}

74. According to published descriptions,

Imperata exaltata, Brongn, the area of distribution of which, to some extent, overlaps that of the present species, is distinguished from the latter mainly by the following characteristics :-

(1) Panicle thyrsiform, 4-5 inches broad at base (F. B. I., VII, 107).

(2) Stamen onc.

(3) Upper spikelets in racemes solitary.

(4) Culm fistular.

(5) Glumes I and II three nerved with mid-nerve reaching, or almost reaching, the apex of glume.

It is therefore interesting to note that, in the local specinens of Imperata arundinacea, Cyrill, the culms are slightly fistular at the base, glumes I and II have $3-6$ nerves and the upper spikelets in the racemes are sometimes solitary.

75. Of Imperata arundinacea three forms can be more or less clearly distinguished locally as under :-

(a) The depauperate form common on lawns or areas where the grass is continually cut or grazed, with minute, almost filiform, culms and small leaves. Leafinsertions usually long-bearded. Glume IV and pale usually glabrous.

(b) The ordinary savannah form which usually attains a height of about $3 \mathrm{ft}$. with leaves up to 0.7 in. wide. Leaf-insertions bearded, or glabrous. Pale and glume IV ciliate.

(c) A robust forin found in sivamps or marshy soil where there is an abundance of available noisture more or less throughout the year. This plant attains a height of $9 \frac{1}{4} \mathrm{ft}$. and probably more. Leaves up to $1 \cdot 1 \mathrm{in}$. wide, leaf-insertions glabrous. Pale and glume IV ciliate. (This plant is var. latifolia Hook f.)

The mode of occurrence of these different forms in their natural habitats and the fact that numerous intermediates are met with, as the conditions vary, indicate that such characters as the vigour of growth (indicated by the diameter and height of the culms, length of the panicles, length and width of the leaves), the hairiness of the nodes, of glume IV and of the pale, are directly dependent on the nutrition of the plant and it is believed that form $(a)$ owes its characteristics to the starving effect of the artificial interference with its normal growth and development, while the peculiarities of form $(c)$ are due to the cxceptionally favourable conditions of available moisture under which it grows.

Plants of all these forms are now being cultivated at Dehra Dun with the object of testing the effect of protection on $(a)$ and of a diminished water supply on $(c)$.

Hackel has subdivided Imperata arundinacea into three varieties of which he further distinguishes sub-varieties, depending mainly on such characters as the hairiness of the leafinsertions, width of the leaves and height of the ligule. The height and shape of the ligule, however, is more or less correlated with the width of the lamina, while the other characters appear to vary with the locality as indicated above and do not define forms of any constancy. 


\section{C.-Biological and CEcological Notes}

Hakitat.

IJevelopment of Culms,

Tegetalive

Activity and

Floweriug.
76. This plant is here chiefly found in the. same localities as Saccharum Munja and Erianthus Ravenno, both of which are stronger and more vigorous species and its distribution appears to depend mainly on two facts :-

(1) It is not sensitive as regards soil aeration and can thrive on stiff clay, while its maximum dimensions are attained (by the swamp form) in the perennially saturated watex-logged soil of the marsh.

(2) The ordinary savannah form requires far less moisture for its vigorous development than does Erianthus Ravennce.

It is thus able to occupy stations into which its stronger competitors cannot penetrate. It occurs on sandy soil with Saccharum Munja, but is most common on heavy soil with a more or less considerable admixture of clay and in the latter case its most frequent associate. is Eragrostis cynosaroides.

The species has considerable power of withstanding shade.

A perennial and usually markedly gregarious species.

The aerial culms spring from somewhat succulent, white, cylindrical, subterranean stolons. These stolons are at first covered and protected by membranous sheaths (= leaves) which eventually fall off, their circular insertions then clearly defining the internodes of the smooth white stolon.

The culm may be the direct continuation of the growing point of the stolon, or it may arise as an axillary shoot from a node of the stolon, or of the basal portion of an aerial culm.

When a stolon is about to produce an aerial culm, its apex turns towards the surface and a few short internodes are developed from the nodes of which new stolons are sent out, the function of which is to provide for the continued growth and extension of the plant below ground.

The production of the true aerial culm is then commenced, a number of short internodes being first formed, then a few long internodes and finally the flowering panicle. The leaves produced on the first internodes are mere scales with no green lamina, on the higher internodes the green lamina progressively increases to its maximum and then again rapidly decreases in size in the leaves of the long uppermost internodes.

In many cases the sinort internodes of the stolon proper are more or less sharply defined, but in others the change from stolon to culm is imperceptible and it becomes impossible to say whether a particular internode is to be considered a part of the stolon, or of the aerial culm.

Taking the ordinary savannah form of this grass, however, an average mature culm usually shows a basal portion of about an inch in length, consisting of 14 short internodes (including the short internoaies of the stolon where these can be distinguished. The exact 
number may vary from 8-18), then four long internodes and finally the apical length which terminates in the panicle.

The leaves on the basal nine internodes are usually scales with no green lamina, so that the average culm produces nine leaves, with a more or less perfectly developed green lamina.

The average period of vigorous vegetative activity is believed to extend from February to October and the majority of the young culms appear to commence their growth at the beginning of the rains in June.

During November--January there is, as a rule, a well-marked period of rest and if an average culm is examined during this period it will be found to consist of a short hard mature basal portion oi about 13 short internodes, the upper four or five of which carry more or less dead and withered large leaves.

Within and above these are one or two not yet fully developed green leaves and finally in the centre at the apex of the culm is the terminal growing point situated close above the upper node of the inature basal portion.

During the season November-January, therefore, the local grasslands of this species show a multitude of short immature culms each of which looks like a tuft of leaves.

The blades of the majority of the leaves of these culms are mature, spreading, fully expanded, and reddish, or brownish, yellow in colour, while only one or two interior and apical leaves are still immature, with their blades convolutely folded and green in colour. This is the cause of the characteristic reddish brown colour of the grasslands in the cold season where this species is dominant. Vigorous vegetative activity is usually resumed the following February and the flowering panicles are produced in May-June. ${ }^{1}$

As the aerial culm dies after flowering, its average duration is about 12 months and it may be described as annual.

It will be noticed that the nurnber of green leaves produced on the culm, viz. 9, corresponds to the number of months' vigorous vegetative activity, viz. June-October in the first year and February to May in the following year, while the culm completes its cycle of development in nine months of vigorous growth.

The above represents what is believed to be the average development of the savannah form in the forest, but individual culms of course vary to some extent in the period of their life cycle and in a plant of this form which was cultivated at Dehra Dun, on moist soil, where activity was not checked at the close of the rains, a culm, regarding which dates were recorded, actually completed its cycle in seven months from June-December.

In the dwarf form characteristic of areas regularly grazed or mown, and also in the marsh form, the number of green leaves produced on the culm is usually greater, i.e. from $10-12$ which is perhaps the result of vegetative activity being possible during a greater number of months in the year.

I In areas where the grass has been cut, grazed, or burnt, vegetative activity commences earlier than usual and flowering usually takes place in March-April. The swamp-form of this species also nsually flowers at the close of the rains, or in the cold senson.

$$
\left[\begin{array}{ll}
9 r
\end{array}\right]
$$


Another irregularity of growth which has been particularly noticed in the case of the marsh form is that a length of long stolen-internodes frequently succeeds a length of very short internodes, which as a rule immediately precedes the aerial culm.

This is believed to be caused by an alteration in the ground-surface level and to the growing points of young culms being covered with fresh deposits of soil and water-brought débris.

The marsh form, also, instead of having only four long internodes below the panicle, usually produces 7 and the immature culms often show a height of 2 to 3 feet and probably more, instead of about 1 inch, at the end of the first rainy season.

This form, however, is comparatively rare, of little value as fodder and, owing to the conditions of its habitat, littlo subject to fire damage, and in the following notes it is left out of consideration.

It must be noted that young culms may commence their development at any time during the period of vigorous vegetative activity and culms which commence their growth towards the end of the rains, or exceptionally early in the following hot weather, may complete their cycle and flower in September-October. In this way the sporadic flowering in the cold season which is characteristic of the species is probably brought about.

On lawns, or grazed areas, where vegetative activity is in progress for about 10 months in the year, the time of flowering is also irregular for the same reason.

The course of development indicated above, however, which results in gregarious flowering towards the close of the hot season is believed to be the rule, at all events in Upper India, and Roxburgh nutes "particularly common over Bengal, where the fields are white with it when in flower, after the first rains in April and May."'

77. During the cold and beginning of the hot season when the sirhu areas are chiefly exposed to fire damage, the aerial portion of the plant consists mainly of the immature short leafy culms, with a few flowering culms and a few young culms which are just commencing their aerial development. The dead and dry aerial portion of the flowering culms is of course liable to be burnt. The growing points of the stolons and of the youngest culms are as a rule situated below the ground surface and are therefore not liable to injury.

The most extensive damage is liable to occur in the case of the immature leafy culms which commenced growth at the beginning of the preceding rains and which in ordinary culurse would produce flowering panicles towards the close of the hot season. The mature leaves of these culms are, as already noted, more or less dead and dry and the burning of this inflammable material may resull in the death of the growing apex of the culm and the nonproduction of a flowering panicle. In this way fires may diminish and interfere with the usual gregarinus flowering in April--May. The extent of the damage done depends largely 
on the quantity of dead dry leaves on the culm and this to some extent depends on the moisture in the soil; where sufficient moisture is available, vegetative activity is prolonged and the leaves persist and remain green well into December, while in drier localities they dry off in November. The period of activity also to some extent depends on the nature of the soil, as does the damage done by firc. The plant occurs both on sandy and loamy soil, the former dries more rapidly than the latter which results in shortening the period of vegetative activity and increasing the number of dead inflammable leaves, while at the same time there is more danger of the fire penetrating below the ground surface. Thus, as a general rule, the drier the locality and the later the fire occurs in the season, the more serious is the damage. An early fire frequently does very little damage and prolific flowering may often be seen in May on areas burnt early in the season.

The following facts all tend to reduce damage done by fire to this species :-

(1) It is usually found on clayey soil which retains moisture tenaciously and conducts heat badly.

(2) The stolons and their growing points from which the aerial culms arise, are usually situated at a considerable depth below the ground surface.

(3) During the seasol: when the grasslands are usually burnt, there are a very few, old, dry and inflammable, flowering culms.

(4) The aerial culms are scattered and at considerable distances apart, insteac of being aggregate $c^{\prime}$ in tufts, so that the quantity of inflammable material and consequently the intensity of the fire at any one point is small.

(5) One or more buds are usually developed from the basal nodes of the aerial culms, or from the nodes of the stolon below it, which as a rule escape being damaged by fire. These develop into aerial culms and are thus able to replace any culm which is destroyed.

On the whole, therefore, the damage done by fires to this plant is slight and fire-damage alone is not likely to be sufficiently severe to cause the destruction of the species.

78. 'The young shoots and leaves of this plant vility as undoubtedly provine good fodder, but the mature lcaves of a normally developed culm are Fodder and too coarse to be relished by cattle. If sirhu areas which have been allowed to develop with- ment Por out interference during the rains are fired in the cold season, or beginning of the hot duction. weather, a number of young leafy aerial culms soon make their appearance, while the destruction of the oid dry leaves exposes clearly to view the young inner green leaves of the older culms as they develop from the uninjured apical buds. These young shoots are usually appreciated by cattle. It must be noted that when the upper green portion of a young culm is bitten off ly a grazing animal the result is not to damage the low-seated apex of the culm itself, but only to more or less completely destroy the upper portion of the leaves, the outer, more fully developed leaves being most injured, their basal portions often alonc escaping, while the inner and upper immature leaves are progressively less and iess 
damaged. The natural resuli of this injury is that only the interior and upper smaller leaves are able to develop, while owing to the more or less complete destruction of the outer and lower leaves, the cuim is pcorly nourished and shows exceptionally feeble development, both as regards the length of the internodes and diameter of the culm. Grazing therefore tends to produce a depauperate form with unusually small green leaves situated close to the ground surface, the mature flowering culms of which are minute, often filiform and a few inches high, with a panicle sometimes not exceeding 1 inch long. Grass-cutting (on a lawn for instance) obviously has precisely the same effect, the interference with the plant's development being more severe, the lower and nearer the ground the shoots are cut or bitten off.

Owing to the period of vegetative activity being prolonged in areas which are grazed, or where the grass is cut, and to the fact that the subterranean stolons during the period of vegetative activity contmue to produce fresh young culms, this species is capable of producing a practically perennial supply of palatable young shoots and small leaves which constitute good fodder, and incidentally it may be noted that, for a similar reason, it is capable of forming a fairly good green sward, or lawn.

As regards the best treatment for pastures of this grass it is obvious that the growth on those areas where the plants have been allowed to develop undisturbed through the rains is too coarse to be of ary value and this ought to be fired if good fodder is desired.

Duthie writes as follows regarding this grass: "Cattle relish it when young." * * "In Australia it is called 'blady grass' and the young succulent foliage which springs up after the occurrence of a fire is much relished by stock. I have observed the same effect resulting from periodicai fires on certain parts of the Himalaya where this grass is plentiful."

"It forms the chief constitlient of the turf in the Botanical Gardens at Calcutta.".

Relations of Grassland to Woodland.
Miscellaneous
79. This species is not an injurious competitor of the Sal tree and in this locality it is only dominant on limited areas which are as a rule unsuitable for the growth and development of Sal seedlings on account of the soil, insufficient aeration, a deficiency of available moisture at certain critical times of year, frost or other causes. Its importance as regards the forest therefore consists mainly in the danger of fire resulting from the masses of inflammable dry leaves existing in the areas occupied by it during the fire season. This danger is best dealt with, in the usual way, by firing the grass under suitable control. It should be noted that if areas which have thus been burnt could be well grazed throughout the rains, the result would be to produce a noninflammable sward which, if continually grazed, would require no further firing. In localities where this grass is plentiful, or could be cheaply introduced, treating fire-lines and blanks in this way might considerably reduce the cost of fire protection.

80. Like kans this species is liable to take possession of agricultural lands which have lain fallow and is then exceedingly difficult to

1 Fodder Grasses of Northern India by J. F. Duthie, p. 23.

${ }^{2}$ List tof the Grasses of North.West 2 rn India (1883) by J. F. Duthie, p. 14. [ 100$]$ 
HOLE : SOME INDIAN GRASSES AND THEIR ECOLOGY.

eradicate, as might be expected, on account of its decp-going' much branched stolons. Hackel (p. 95) notes that in the East India Islands it occupies vast areas of fallow lands, to the exclusion of almost all other plants. It is there called alang-alang.

In India the succulent white stolons are eaten by pigs and areas which have been wellworked by pigs in their search for the stolous are not infrequently seen in the forest. It is possible that in some cases the eradication of the species might be cheaply accomplished by the aid of pigs.

Schimper, ${ }^{1}$ quoting Junghuhn, speaks of this grass as follows in the Malayan Archipelago :-

"When the soil remains uncultivated after clearing the forest, as a rule the social and dense-growing alang-grass first replaces the vanished forests, then areas extending for miles, even indeed for whole days' journeys, are transformed into a uniform wilderness of dense grass three to five feet high, while on mountain-slopes the same grass extends far beyond its original zone, and spreading over everything it ranges up to altitudes of $6,000-7,000$ feet, being almost insensible to differences of temperature. Its silken haired seeds, light as the tenderest down, are wafted away in millions by the slightest breath of wind and greatly facilitate its general distribution, while its creeping and deeply penetrating roots increase the difficulty of eradication when once this grass, so tenacious of life, has established itself. I have reasons for believing that while the land was in its original condition the alang-grass was restricted to sundry sterile, arid, waterless tracts of the hot zone, and was chiefly confined to heavy, hard, easily dried clay soil, with an iron-pan, but that at the present time, wherever we meet this grass on a fertile light soil and on mountain-slopes at above 2,000 feet, this state of affairs is first brought about by the hand of man . . . In Northern Sumatra, especially in the Batta country that has been devastated by war, grassy wastes have consequently come into existence which cover everything far and wide with a hideous uniformity and overrun plain, mountain, and valiey with their whitish-green mantle."

\section{D.-Economic Uses.}

81. In addition to its value for fodder this grass under the name of "lalang" has recently been favourably reported on as a papermaking material :

"The ultimate fibre obtained from this grass is very similar in most respects to Esparto; the yield of bleached fibre being about the same. This is a favourable indication inasmuch as 'Esparto' is one of the best known and most useful sources of supply to the 
trade **. The results obtained from the chemical analysis show that the grass is capable of yielding a good quality of cellulose, suitable in every way for the manufacture of paper."

The value of the leaf for paper manufacture probably depends mainly on the existence of the well developed groups of sclerenchymatous fibres which form the girders of the vascular bundles.

The leaves are largely used for thatching.

Triraphis maảagascariensis, Hook f. ex Prain in Bengal Plants, II, 1219.

(Plates IV and XXXI to XXXIII.)

References.

F. B. I., VII, 305. (Under Neyraudia madagascariensis.)

P., II, 1219.

Distribution.

Tropical Himalaya and Sub-Himalayan tract from Punjab to Assam, Burma.

Extends to China, Java, Africa and Madagascar.

\section{A.-Description.}

Vernacular

Name.

Culm.

Leaf-sheath.

Lamina.

Ligule.

Inflorescence.

\section{Bänsi (Dehra Dun).}

Erect, slender, attains a height of $10 \mathrm{ft}$. (Prain gives $15 \mathrm{ft}$.) and diameter of $0.25 \mathrm{in}$. (F. B. I. gives 0.5 in.).

Usually solid above and fistular below. Sometimes solid throughout.

Glabrous, striate, green in colour, pruinose when young, polished when old. Secondary culms are often produced from the upper nodes.

These are frequently poorly nourished and may show a diameter of only $0.05 \mathrm{in}$.

Glabrous.

Of uppermost leaf of flowering culm usually well-developed and attaining a length of $2 \mathrm{ft}$. and width of $0 \cdot 25 \mathrm{in}$.

In depauperate culms it may be only $4 \mathrm{in}$. long with a width of $0.05 \mathrm{in}$.

Of lower leaves attains a length of $2 \frac{1}{2} \mathrm{ft}$. and width of $0.5 \mathrm{in}$. (F. B. I. gives width of 1 in.)

Linear, long acuminate, slightly narrowed near the sub-amplexicaul base. Greatest width attained within the basal eighth, or within 3 inches from base. Usually jointed to, and deciduous from, the sheath.

Scaberulous on margins alid also on the nerves on both surfaces, especially towards the apex (F. B. I. gives smooth). A few long hairs on margins and inside at base.

A villous ridge.

Spikelets solitary, pedicelled, on the fascicled or whorled branches of a terminal panicle

Primary rachis glabrous or scaberulous. Branches and pedicels scaberulous. 
Panicle attaining a length of $3 \mathrm{ft}$. but in depauperate specimens only 6 inches long. Branches of flowering panicle spreading, arcuate, of fruiting panicle, erect, or ascending, and adpressed to rachis.

0.25 to 0.45 in. long, including the awn, 3-9 flowered, with two empty basal glumes. Spikelets. (In addition to the empty glumes the lowest flowering glume, III, is sometimes epaleate, neuter and glabrous, but this has not been found in the local plant.)

Glume 1.-Empty, lanceolate, 1 nerved, mucronulate, scaberulous dorsally on nerve. Membranous, brown in colour.

Glume II.--Empty, usually a little longer than I, oblong-lanceolate, mucronulate, 1 nerved, scaberulous or smooth dorsally on nerve. Membranous, brown in colour.

Flowering glume (Glume III).--Longer than the empty glumes, broad subulate, 3 nerved, with two lateral keels. Apex slender with two setaceous points and an interposed scaberulous awn. Awn about $\frac{1}{2}$ length of glume and recurved in fruiting spikelets, but not twisted. Dorsally villous with long white hairs along the keels. The remaining flowering glumes are similar.

Pale. $-\frac{2}{3}$ to $\frac{3}{4}$ flowering glume, oblong, 2 nerved, with two lateral keels, hyaline, minutely scaberulous dorsally along the keels, glabrous.

Apex truncate, minutely two dentate.

Lodicules.-Minute, two, cuneate or obovate, glabrous.

Anthers.-Three, 0.07 in. long, yellow.

Stigmas.-Two, 0.03 in. long, hardly exserted from spikelet.

The rachilla, which is continued beyond the upper flowering glume, is jointed at the base above the empty glumes and between the flowering glumes. The portion of the rachilla above the joint and below the next flowering glume (=the callus) is densely bearded with short white hairs.

The fruiting spikelet breaks up at the joints of the rachilla, from the apex downwards, the basal empty glumes persisting longest.

\section{B.-TAXONOMY.}

82. In F. B. I. two forms of the species are given :-

(1) madagascariensis proper; neuter glume O. Western Himalaya, Burma, Africa, Madagascar;

(2) Zollingeri; neuter glume present. Eastern Himalaya, Assam, Bengal, Burma, Java; 
but the author writes: "I can find no difference whatsoever between the specimens with and those without the empty glume III." All specimens of the local plant examined have no neuter glume and fall under (1) above.

The description under (A) above which (with the exception of the characters in paren-. theses) refers exclusively to the local plant (i.e. to the form madagascariensis), growing under varying conditions of soil-moisture, shows that this is a decidedly less robust plant than the species as understood by Prain and in the F. B. I. which also includes the form Zollingeri (=A rundo Reynaudiana Kunth).

The latter also has a different area of distribution and although starved specimens of both these plants exist which, especially in herbaria, are likely to mask the differences between them, it seems probable that they will prove to be distinct species. The writer, however, has at present no knowiedge of the E. Himalayan plant in the field and pending the results of further study it seems advisable to deal with these forms as varieties as follows :-

(1) madagascariensis proper: Glume III similar to IV and fertile.

N. W. tropical Himalaya and Sub-Himalayan tract from Punjab to Kumaon, Africa, Madagascar.

(2) Reynaudiana: Glumes III and IV heteromorphous, III empty.

E. Himalaya, Assam, Bengal, Burma, China, Java.

Specimens kindly sent me by Dr. Stapf, of the African plant from N. Madagascar (Revd. R. Baron, 6353) with spikelets $0 \cdot 31$ to $0 \cdot 34 \mathrm{in.}$ long, appear to be identical with those of the N. W. Himalayan form.

\section{C.-Biological and CEcological Notes.}

83. This plant is sometimes associated with

A ristida cyanantha on gravel and boulders, but as a rule only becomes dominant where there is a considerable admixture of sand, and where there is still insufficient moisture for a vigorous development of Saccharum Munja.

With it are often found the xerophilous form of Saccharum spontaneum and S. Munja. and also Andropogon monticola.

In many respects this grass closely resembles Aristida cyanantha. Like the latter the present species, in its usual local habitat, shows a well-marked resting season during December-January.

It however also grows vigorously on moist loam under cultivation and then shows a less sharply defined period of rest.

Plants taken from sand at once established themselves strongly in loam and the species is therefore apparently not so sensitive as A ristida in respect of soil aeration.

Isolated plants are occasionally met with growing well in shady Sal forest and it probably has a stronger capacity for withstanding shade than A ristida. 
84. The young culm in this species shows an Berelopment average of 10 short basal internodes carrying scales, after which each leaf carries a well- Season of developed lamina. The average mature flowering culm shows these 10 short basal inter vegetative nodes, then 10 long internodes and finally the panicle, thus giving 10 green leaves for the Flowering. culm which suggests 10 months as the usual period of vegetative activity and indicates that the arerage culm usually commences vigorous growth in February. This however has not ret been satisfactorily determined.

Flowering takes place in September-November and the culms are annual.

The remarks given below, referring to additional points under this head, for Aristida cyanantha also apply to this species.

heads for A ristida also apply to this species.

85. The remarks given below under these $\begin{gathered}\text { Susceptitiol- } \\ \text { ity to Fire }\end{gathered}$

Damage.

Ctility as

\section{D.-Economic Uses.}

86. Is of some value on dry sandy, or gravelly,

soil as a pioneer of better vegetation.

\section{Aristida cyanantha, Steud ex Trin. (Plates II and XXXIV to XXXVI.)}

F. B. I., VII, 225 (excl. ref. Royle Ill. Bot. Himal.).

References.

Western Himalaya and Sub-Himalayan tract from Kashmir to Kumaon.

Distribution。

Ascends to 5,000 feet. Extends to Afghanistan.

\section{A.-Description}

Suhi, suhni (Dehra Dun).

Erect, slender, attains a height of 10 feet and diameter of 0.21 in

Solid throughout.

Glabrous, striate, green in colour.

Secondary culms are often produced from the upper nodes which are usually poorly nourished and show inferior dimensions.

Glabrous.

Leaf-slieith.

The lamina disarticulates from the sheath and after the shedding of the lamina the culms are covered with the straw-coloured persistent sheaths. The latter are also then shed and the green culms are left naked from base to apex.

Of uppermost leaf of flowering culm usually well-developed. On poorly nourished tamina. culms 4 inches long but attaining a length of $1 \frac{1}{2}$ feet.

Of lower leaves attains a length of 2 feet 4 inches and width of $0.25 \mathrm{in}$.

Linear acuminate, tapering from the base.

Jointed to and deciduous from the sheath. 
Scabrid on margins and dorsally on midrib, especially towards the apex (leaves quite smooth fide F. B. I.).

Ligule. A minute membranous rim, ciliate.

Inforescence. Spikelets solitary, pedicelled, on the capillary branches of a terminal panicle.

Primary rachis, branches and pedicels scaberulous.

Panicle 1-2 feet long, conical; branches solitary, fascicled, or sub-verticillate, filiform, wide-spreading, arcuate.

Sptkelets. Narrow $0.45-0.65$ in. long (excluding awn of glume III), one flowered. Flowering spikelet is dark purple.

Glume I.-Linear lanceolate, $0 \cdot 2-0 \cdot 3$ in. long.

Awned, awn 0.05-0.15 in.

Membranous, scaberulous dorsally on keel.

One nerved.

Glume II.-Broad subulate, 0.4-0.52 in. long.

Awned, awn $0 \cdot 05-0 \cdot 13$ in.

Membranous, smooth dorsally.

One nerved.

Apex entire or fimbriately toothed.

Glume III.-Linear, $0 \cdot 3-0.42 \mathrm{in.} \mathrm{long,} \mathrm{terminating} \mathrm{in} \mathrm{three} \mathrm{long} \mathrm{awns.}$

Awns subequal, or the middle slightly longer than the others, scaberu-

lous, $1 \cdot 6-2 \cdot 1$ in. long (attain $2 \cdot 5$ in. fide F. B. I.), not articulate to the glume.

In the flowering spikelet, the awns are erect and closely adpressed, in fruiting spikelet they separate and are wide-spreading.

Glume is chartaceous, convolutely folded, glabrous, three nerved.

Pale.-Oblong, hyaline to sub-opaque, two nerved at base, $0.05-0.06 \mathrm{in}$. long.

Glabrous, completely enveloped by glume III.

Apex sub-truncate or 2-3 dentate.

Lodicules.-Two, cuneate, obovate, or ob-lanceolate, a little shorter than to subequal the pale, 0.03 to 0.05 in., glabrous.

Anthers.-Three, $0 \cdot 17-0 \cdot 2$ in. long, yellow, more or less suffused with purple. Filaments short.

Stigmas.-Two, 0.05-0.1 in. long, purple; styles short.

The rachilla, which is not produced beyond glume III, is jointed above the empty glumes I and II, and the latter persist after the fall of the grain. The portion of the rachilla above the joint and below glume III (=the callus) is bearded with short white hairs.

Field Chara- $\quad$ The spikelets are often attacked by a fungus Ustilago Aristidce-cyanantho Bref. and ters. a spikelet which has been attacked develops a remarkable pod-like structure, which is filled 
with the black powdery spores, and these fruit-like bodies give the panicles a most characteristic appearance.

It is interesting to note that this fungus was originally described by Brefeld from a specimen "collected in Dehra Dun" and sent by D. D. Cunningham from Calcutta. It has apparently not been reported from other localities.

\section{C.-Biological and Ecological Notes.}

87. This plant is gregarious on the soil-less Habitat. banks of gravel and shingle found in and near the beds of steep water-courses.

While as a rule markedly gregarious and the dominant species in its own station, this plant is not infrequently associated with Andropogon monticola and occasionally with Triraphis. In its local habitat the species completes its annual growth within the period February--November and shows a well-marked resting season during December-January.

In plants which under cultivation are found to grow well on moist loam the resting period is less sharply defined, the young culms commencing their development and continuing to grow slowly after the close of the usual period of activity.

Plants taken from sandy, or stony soil, find some difficulty in establishing themselves on loam, but some individuals adapt themselves to such changed soil conditions more readily than others. The species therefore appears to be sensitive to some extent as regards good soil aeration.

Isolated plants are occasionally seen to have obtained a footing in Sal forest and here it can be seen to possess some capacity for withstanding shade.

88. This plant is perennial and is usually Derelopmeni gregarious. It consists of a much branched rhizome which constantly grows outwards of Culm, of centrifugally in all directions.

The culms are either produced from the branches of the rhizome, or they arise from the Vegetative Activity and basal nodes of older culms, either above or below the ground surface.

The culms usually arise close together and well-defined clumps are produced.

The culms are annual, flowering taking place in September-November.

In the moist soil of the garden at Dehra Dun, vigorous growth was observed throughout the winter of 1909-10 which however was exceptionally mild. In the dry localities where it is usually found in nature there is as a rule a well-marked period of rest during December and January.

The aerial culms usually die back after flowering, but their lower internodes occasionally persist and produce secondary culms from their nodes.

The young culm usually shows 6 or 7 very short basal internodes carrying scales, above which all the leaves have a more or less well-developed green lamina. The mature flowering culm also shows the short $6-7$ basal internodes, as a rule aggregating less than an inch in length, defined by the internodes of the scales, then 9 long internodes, then a comparatively 
short internode, and finally the terminal segment carrying the panicle. This gives 10 green leaves for the mature culm which suggests 10 months as the period of activity and indicates that the average culm usually commences vigorous growth in February. This, however, has not yet been satisfactorily determined.

The culms are distinctly green, while the green leaf lamina is often deciduous in Ostober, the sheath persisting for some time longer. It is possible that the green culms to some extent function as leaves.

Susceptibility to Fire Damage.

Utility as Folder.
89. This species usually shows a well-marked period of rest, in the dry localities which here form its natural habitat, during the months December-January. During these months the clumps contain only the old culms which fiowered the preceding September-November, while next year's culms have not yet commenced their growth and exist as large buds well protected by hard scaly leaves.

Soon after flowering, also, the lear-sheaths fall away from the culms and during the period of rest the clumps have a very striking appearance, consisting as they do only of naked green culms terminating in the panicles, with no leaves and no leafy immature culms. At this period the old culms are not yet thoroughly dry and the clumps contain practically no inflammable material.

Although the species has a tufted habit and occurs on sandy soil it is, in consequence of the above facts, not subject to damage by an early fire.

A late fire, when the old culms and soil are thoroughly dry and the young culms have commenced their growth, may cause severe damage.

for fodder.

90. This species is believed not to be utilised

\section{D.-Economic Uses.}

91. The upper portion of the flowering culm with the attached panicle is cut off and several of these being tied in small bundles the latter are used as brooms.

This species is of considerable value as a pioneer on gravel and shingle banks which there resists erosion and gradually improves the soil and prepares the way for better vegetation.

\section{Andropogon monticola, Schult. (Plates XXXVII to XXXIX.)}

References. $\quad$ F. B. I., VII, 192; H., pp. 557-558 (under A. monticola and A. Trinii); C., II, 985. P., II, 1205.

Distribution. Throughout India, especially in hilly tracts, from N. W. Himalayas southwards, ascending to 6,000 feet.

Extends to Burma, Ceylon, Afghanistan, Africa. 


\section{A.-Description.}

Dhaulu, gurle, gorha (Dehra Dun). Gogad, ghora (Central India, Bombay). Fernacular Geniculately ascending, attains a height of 7 feet (in local plant usually $3-5$ feet) $\begin{gathered}\text { Name. } \\ \text { Culm. }\end{gathered}$ and diameter of $0 \cdot 2$ in.

Slightly compressed.

Solid.

Smooth.

Axillary leafy and flowering branches are usually developed from all the upper nodes except the one next below the panicle.

These branches developing within the sheaths, push out the latter away from the culm and often produce a characteristic fan-shaped appearance.

Glabrous.

Compressed, keeled, especially of the lower leaves.

Shorter or longer than the proper internode.

Of uppermost leaf of flowering culm usually mucroniform but attains a length of Lamina. $3 \cdot 3$ in.

Of lower leaves attaining a length of 1 foot 5 inches and width of $0.3 \mathrm{in}$. Vernation conduplicate.

Linear acuminate, tapering from base.

Scabrid on margins. Sometimes also scabrid dorsally on midrib, and scaberulous above, especially towards the apex. Often ciliate towards the base with tubercle-based hairs, at least when young.

A minute membranous rim, ciliate.

Spikelets in cluster's of 3 (a central sessile $\delta$ spikelet with two lateral pedicelled $\delta$ Inforescence spikelets), the clusters being terminal and solitary on the capillary, sub-verticillate, branches of a terminal panicle.

Panicle rachis and branches smooth or scaberulous.

Panicle 2 inches - 6 inches long. Ovate to sub-cylindric, yellowish to purplish in colour. The branches of the flowering panicle are more or less horizontally spreading, those of the fruiting panicle are erect and closely adpressed to the rachis.

Each cluster of three spikelets is deciduous as a whole, an ovate scar, shortly fringed with stiff rufous hairs, then terminating the panicle branches and becoming conspicuous.

The swollen base of the panicle branches apparently functions as a pulvinus in connection with the movements of the panicle branches.

The flowers of this species are much visited by small pollen-collecting bees.

Laterally compressed, $0 \cdot 17-0 \cdot 23$ in. long, excluding the awns (Hackel gives $0 \cdot 16$ to Sessile $0 \cdot 28$ in.).

Glume I.-Laterally compressed, narrow-oblong, embracing the margins of II at the base.

Chartaceous 2-4 nerved. 
Hispidly ciliate dorsally on keel towards the apex or almost glabrous.

Often scaberulous dorsally on nerves and minutely pubescent with adpressed hairs dorsally near margin.

Apex sub-truncate or two dentate.

Glume II.-Laterally compressed, broader than I, obtusely kecled, sub-coriaceous, three nerved.

Margins broad, hyaline, membranous, ciliate or not.

Very variable as regards its hairiness. Sometimes almost glabrous, at other times hispidly ciliate dorsally on keel with long white or rufous hairs more or less from base to apex.

Sometimes also pubescent, or minutely villous, dorsally on keel and on lateral nerves.

Awned, awn $0 \cdot 1-0.25$ in. long.

Apex entire or two lobed.

Glume III.-From $\frac{1}{2}$ to subequal II, linear, hyaline, ciliate, enerved or indistinctly 1-3 or more nerved.

Apex obtuse.

Glume $I V$.- The narrow 3 nerved base of an awn.

Basal half or $\frac{2}{3} \mathrm{rds}$ hyaline, membranous, upper portion chartaceous. Awn geniculate $0 \cdot 40-0 \cdot 7$ in. long including the twisted column. (Attains $\mathbf{1} \cdot 3$ in. fide F. B. I.) Margins ciliate or not.

Apex entire or two lobed.

Pale.-Sometimes present, very narrow, 0.05 in. long.

Lodicules.-Two, cuneate, glabrous.

Anthers.-Three, 0.07 to 0.13 in. long, yellow or purple.

Stigmas.-Two, 0.06-0.08 in. long, laterally exserted at base of spikelet. Yellow.

Dorsally compressed, subequal the sessile spikelet.

Pedicel is less than half the sessile spikelet, usually about $\frac{1}{3} \mathrm{rd}$ the spikelet, and is densely ciliate on two margins with stiff rufous (or white, fide F. B. I.) hairs, the upper of which are shorter than to subequal the spikelet.

Glume I.-Lanceolate, membranous, 5-7 nerved. Minutely pubescent with adpressed hairs dorsally, especially towards the apex, or almost glabrous. Sometimes ciliate dorsally on midrib and on marginal nerves, especially towards the apex. Acute or shortly awned.

Glume I1.-Subequal I, 3 nerved, margins incurved, long ciliate, apex acute or mucronate, glabrous dorsally.

Glumes III and IV.-Linear, hyaline, ciliate, enerved or indistinctly nerved.

Pale.-Sometimes present, as in sessile spikelet, but slightly longer, very narrow. 


\section{B.-Taxonomy.}

92. Hackel separates two species mainly by

the following characters:-

Andropogon monticola, Schult.-Glume II of sessile spikelet keeled, the keel from base to $\frac{2}{3}$ or $\frac{3}{4}$ its length densely pectinate ciliate with long rigid rufous hairs, shortly white hispid in upper $\frac{1}{4}$.

Andropogon Trinii, Steud.-Glume II of sessile spikelet keeled below the apex only, keel white ciliate.

Remaining $\frac{2}{3}$ or $\frac{3}{4}$ of the glume dorsally, not keeled, glabrous.

In F. B. I., both of the above are included as varieties in one species named A. monticola, Schult, and the author remarks : I am unable to classify the varieties of this common and variable plant in accordance with geographical areas on other considerations. This, if possible, must be effected by field botanists in India. There is every gradation from the coarsely hirsute keel of monticola, to the perfectly smooth of some states of Trinii." The author, however, differentiates and describes an additional variety which he names robustus. The latter is founded on a plant collected by Strachey and Winterbottom which shows the basal $\frac{2}{3}$ or $\frac{3}{4}$ of glume II of sessile spikelet more or less pectinately ciliate with white hairs. All these three described forms appear to vary greatly, as regards their habit and vigour of growth, in response to the moisture conditions of the habitat and also according as whether, or not, the plants are habitually grazed, cut for fodder, or periodically burnt. The colour of the cilia of glume II of the sessile spikelet (pale or white in robustus and rufous in monticola), accordingly, appears to be the chief difference between monticola and robustus, rather than any difference in the habit, and these forms appear to have different and fairly defined areas of distribution (monticola occurring chiefly in Central and Southern India, while robustus is mainly found in N. India, in the outer N. W. Himalayas and SubHimalayan tract). In the F. B. I. the author includes under robustus a plant (No. 555 collected by King at Goona, Central India), glume II of the sessile spikelet of which is dorsally ciliate in the basal $\frac{3}{4}$ with long rufous hairs and which appears to be referable rather to monticola. In the locality with which the present paper is chiefly concerned the forms of this plant which occur are robustus (taken in the narrow sense of Strachey and Winterbottom's plant alone) and Trinii. Both when studied with herbarium specimens and also in the field, however, the local plant gradually and imperceptibly passes from typical robustus to typical Trinii. It is believed that a similar passage takes place between monticola and Trinii in Central and S. India. Further research, however, in the field is required to establish this and also to decide whether monticola can be separated from robustus. For the present it seems desirable to follow the F. B. 1. and to unite these forms into a single species and this has been done in (A) above. So far as the local plant is concerned specimens with the more hairy glume II tend to occur in localities where there is a scarcity of available 
moisture, both on the dry ridges and slopes of the Siwalik Hills and also (rarely) on water-. logged soil, and the writer believes that the characters which have been utilised to define these varieties vary in response to the factors of the habitat and particularly in response to the available water supply. ${ }^{1}$ Provided that the development of the plants has not been interfered with by grazing, grass-cutting, or other agency, those plants with the more hairy glume II are usually less robust and less coarse, or rank, than the others, and they are therefore as a rule most valued for fodder and are distinguished locally by the vernacular name of dhaulu, whereas the coarser plants with smooth glume are called gurla. As this grass affords a valuable fodder and is sometimes cultivated, in consequence, it is important to determine the extent to which its characteristics are constant. If, as suggested above, they depend on the available moisture, it is obvious that cultivation of this grass on good agricultural land, with a large quantity of available moisture, would result in producing an inferior class of rank, coarse fodder.

The local forms of the species are now being cultivated in the Experimental Garden at Dehra Dun with the object of studying the effect of different soils and varying quantities of available moisture on their characters.

This will, it is hoped, indicate which forms (if any) of this species are of sufficient importance and sufficiently constant to deserve separate definition and description.

To separately define forms which are connected in the field by numerous intermediates greatly increases the difficulty of identification and is of little practical utility inasmuch as such forms are not likely to remain constant under the ordinary conditions of field-cultivation.

\section{C.-Biological and Ecological Notes.}

93. This plant is in this locality almost invariably found on dry sandy, or stony, soil, with little capacity for holding water.

It is a frequent associate of A ristida, Triraphis and Saccharum Munja. These plants however are all more vigorous and robust than the present species and Andropogon monticola only exceptionally becomes the dominant species under conditions unfavourable for the vigorous development of these stronger competitors. Such conditions are provided by the hot, waterless, and more or less soil-less, ridges and slopes of the Siwaliks, especially on the south of the range, and on deeper moister soil where the stronger competitors are prevented from developing by fire, or other factors. At least one area in the present locality has been seen near Bullawala, where repeated firing has killed out the coarse savannah species Saccharum Munja and has resulted in making Andropogon monticola the dominant grass. This would undoubtedly occur more frequencly were it not that the burnt grasslands are irequently heavily grazed.

\footnotetext{
$x$ The interesting fact which has been noted regarding this species that the flowers are much visited by bees naturally suggested that intercrossing might be responsible for intermediate forms and for confusing the boundaries of distinct types, but field study indicates the available mcisture supply as the chief factor affecsing the characteristics in question.
} 
Andropogon monticola is probably the most valuable fodder grass in this locality and on grazed areas it is severely handicapped by being constantly eaten down, level with the ground, which not only seriously diminishes the vigour of the plant, but prevents the production of flowers and seed. Moreover in such burnt and grazed areas, on sandy soil, Zizyphus Jujuba frequently appears, woodland then replacing the grassland.

This plant is not infrequently seen growing in the middle of Zizyphus bushes on grazing grounds and therefore has some capacity for withstanding shade, but in shady stations its place is usually taken by A pluda varia. Plants of this species are only rarely found on poorly aerated heavy soil and on loam its place is usually taken by Andropogon intermedius, or Andropogon contortus. Plants taken from sandy soil and then cultivated on loam often adapt themselves with considerable difficulty to the new soil conditions and the species appears to be as a rule sensitive as regards soil-aeration. This is a point of considerable importance as this valuable grass is sometimes cultivated and a case has been seen where the attempt to introduce it on heavy soil had ended in failure.

94. A perennial, usually gregarious and Devclopment forming centrifugal clumps as in A ristida. The young basal culms examined of this species Season of show an average of 11 very short basal internodes, carrying closely imbricating scale-like vetivity and leaves, with little or no lamina, after which each leaf carries a more or less well-developed lamina.

The flowering culms examined show, in addition to the short basal internodes, ${ }^{1} 11$ long internodes and finally the panicle, thus giving 11 green leaves for the culm, and indicating 11 months as the period of vigorous vegetative activity. The culms are annual, but the exact period of activity varies considerably with the locality and the quantity of available moisture.

In the moist loamy soil of the Dehra Dun Experimental Garden vigorous growth was observed throughout the winter of 1909-10, which however was exceptionally mild. In moist localities, therefore, growth apparently continues more or less throughout the year. In the dry localities where this species is usually found locally, however, there is as a rule a well-marked period of rest during December and January and in such places the usual period of vigorous activity is 9 months from February to October.

The majority of the culms start growth in February and flowering takes place in September-October. Culms commencing vigorous growth in February have shown an average number of 9 long internodes. After the production of the terminal panicle, the axillary shoots developing from the lower nodes of the culm (=secondary culms) proceed to flower in their turn and in this way flowering may continue for several weeks or even months.

1 It must be noted that the number of short basal internodes varies with the position of the culm. Culms which originate at, or below, the ground surface usually show the greatest number of short basal internodes, while culms which arise from the upper axils of older culms often show only 1 or 2 such internodes, and sometimes none at all. 
The aerial culms usually die back after flowering, but their lower internodes occasionally persist and tertiary culms are sometimes produced from the lower nodes of the secondary culms.

Susceptibility to Fire

Damage.
95. In this locality the present species is tisually dominant in dry localities and here it usually shows a well-marked period of rest during December-January.

During these months the clumps contain only the old culms which flowered the preceding September-November, while next year's culms are visible as large buds below, or close to, the ground surface.

Although the species has a tufted habit and usually occurs on dry sandy soil, it is not as a rule severely damaged by an early fire, owing to the fact that the young culms are still, as a rule, below the ground surface and well-protected by their imbricating scaly leaves.

The majority of the leaf-bearing branches of the mature culms also spring from the upper internodes of the culms and an early fire which destroys the dry inflammable leaves on the mature culms does not, as a rule, develop a dangerous intensity of heat at the base of the clumps in the neighbourhood of the buds from which the next season's culms will be developed.

This species therefore is as a rule less subject to severe damage by an early fire than is Saccharum Munja for instance.

\section{D.-Economic.}

96. Lisboa writes as follows regarding this species :-

"In Mount Aboo it is reckoned as a good fodder grass and the grain used as food by the natives," and under the name of Andropogon serrulatus, Trin., he adds : "Said to be good fodder, used much in Poona, but reports from other places unfavourable."1

In the local Siwalik Division it is one of the most valuable fodder grasses. 


\section{H A P T E R I I.}

\section{(ii) Summary of Chief Characteristics of Species dealt with.}

97. Before proceeding to the next chapter in which a few suggestions are made regarding the practical treatment of grasslands, it is perhaps advisable to briefly summarise the principal characteristics of the species described above.

This is done in the following table in which the species are arranged in order according to their relative (1) capacity for growing vigorously in a dry soil, (2) capacity for enduring shade, (3) capacity for enduring bad soil-aeration and (4) capacity for withstanding the injurious effect of an early fire in December--February. The species with the greatest capacity for thriving in a dry soil, and for enduring shade, bad soil-aeration and fire, respectively, has been in each case placed first. Species joined by a bracket are believed to have an approximately equal capacity. With regard to the capacity for thriving in a dry soil, also. the duration of the culm is of interest; this has therefore been noted and it will be seen that the species able to grow well in dry soil usually have annual culms :-

\begin{tabular}{|c|c|c|c|c|}
\hline $\begin{array}{l}\text { Capacity for thriving in s } \\
\text { dry soil. }\end{array}$ & $\begin{array}{l}\text { Duration of } \\
\text { Culm. }\end{array}$ & $\begin{array}{l}\text { Capacity for enduring } \\
\text { Shade. }\end{array}$ & $\begin{array}{l}\text { Capacity for enduring bad } \\
\text { Soil-Aeration. }\end{array}$ & $\begin{array}{l}\text { Capacity for resisting injurious } \\
\text { action of an early Fire. }\end{array}$ \\
\hline $\begin{array}{l}\text { Andropogon monticola. } \\
\text { Aristida cyanantha. } \\
\text { Saccharum spontaneum. } \\
\text { Triraphis madagascariensis. } \\
\text { Imperata arundinacea. } \\
\text { Saccharum Iunja. } \\
\text { Saccharum Narenga. } \\
\text { Erianthus Ravenna. }\end{array}$ & Biennial. & $\begin{array}{l}\left\{\begin{array}{l}\text { Saccharum Narenga. } \\
\text { Erianthus Ravennæ. }\end{array}\right. \\
\left\{\begin{array}{l}\text { Imperata arundinacea. } \\
\text { Triraphis madagasca- } \\
\text { riensis. }\end{array}\right. \\
\left\{\begin{array}{l}\text { Saccharnm Nunja. } \\
\text { Saccharum spontaneum. }\end{array}\right. \\
\left\{\begin{array}{l}\text { Andropogon monticola. } \\
\text { Aristida cyanantha. }\end{array}\right.\end{array}$ & $\begin{array}{l}\left\{\begin{array}{l}\text { Imperata arundinacea. } \\
\text { Saccharum spontaneum. }\end{array}\right. \\
\left\{\begin{array}{l}\text { Erianthus Ravennæ. } \\
\text { Triraphis madagascariensis. }\end{array}\right. \\
\text { Saccharum Narenga. }\end{array}$ & 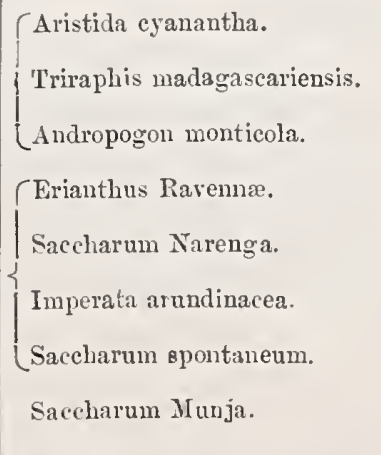 \\
\hline
\end{tabular}

The above table summarises the infornation obtained from careful field observations in the locality defined in Chapter I above, supplemented by the results obtained from the limited experimental cultures which alone have been possible up to date. It is therefore to be expected that instrumental field observations and extended and careful experiments designed in such a way as to give accurate information regarding the effect of each individual factor on the growth of the different species will to some extent modify the conclusions summarised above. On the whole, however, it is believed that the conclusions drawn are fairly accurate and that they will be of utility. It is believed that the observatiors which have been made regarding each species embrace the principal classes of habitat 
in which the plant is naturally found and that therefore the results obtained will to a considerable extent apply to areas other than that in which the information has been collected. Alterations in climate, by affecting the period of vegetative activity, will no doubt to some extent modify the above arrangement as regards fire-damage.

In the present paper, however, what appears to be the normal life bistory of the culms of each species has been carefully explained and the connection between this development and the damage done to the plant by fire has been indicated. This information therefore will, it is believed, enable anyone to form a good idea of the liability of these species to fire damage in any particular locality, by observing the differences in the life history produced by local climatic conditions.

As regards ability to thrive in a dry soil, the arrangement given above merely refers to what is believed to be the average capacity of the species, as it occurs in nature. Thus the swamp form of Saccharum spontaneum can only thrive, i.e. attain average dimensions on a soil containing large quantities of water and the quantity of water actually utilised by a plant of average vigour of this form is probably not less than that utilised by an average plant of Saccharum Munja. On the other hand, however, the majority of the individuals composing the species Saccharum spontaneum, as it exists in nature, do not belong to the typical swamp form but to the forms commonly found on dry sand and wet agricultural lands. Taking these into consideration therefore the average plant of Saccharum spontaneum is able to thrive on a drier soil than the average individual of Saccharum Munja.

A similar point of view has been taken in arranging the species with regard to other factors.

Thus as regards soil-aeration in species like Andropogon monticola, Saccharum Munja, and $A$ ristida, which in nature as a rule are found on well-aerated soil, a comparatively few individuals can be found growing well on heavy, less aerated soil. Plants of all these species taken from well-aerated soil and then cultivated in Dehra Dun on loam have all shown in a single season :-

(1) Some plants which entirely fail to adapt themselves to the new soil and die, or which adapt themselves with difficulty and show inferior growth.

(2) Some plants which adapt themselves at once to the new soil and show average dimensions.

We almost certainly have an example here of individual variation and of the power possessed by individual plants, in a greater or less degree, of adapting themselves to new conditions, and if the comparatively few individuals of these species which can be found in nature growing on heavy soil are experimentally cultivated, they would almost certainly show greater capacity for enduring poor soil aeration (probably equal to that of Saccharum Narenga or Erianthus) than those taken from sandy, stony places.

At the same time the average plant of these species, at all events in the present locality, certainly does not occur in dense, poorly aerated soil and the above arrangement has been 
based on what is believed to be the capacity of the average individual of the total aggregate of individuals which compose the species in nature.

Again as regards fire-damage, Saccharum spontaneum in a swamp or wet clay is practically free from early fire-damage, but, on the other hand, individuals on dry sand may be considerably damaged, and on the whole, therefore, this species cannot be placed in the first class of fire-resistant plants. 


\section{H A P T E R I I.}

\section{Suggestions regarding the Practical Treatment of Local Grasslands.}

98. Before attempting to make suggestions regarding the practical treatment of grasslands it is obvious that we must clearly define the object which we desire to attain, seeing that it is frequently impossible to satisfactorily attain two distinct objects by one and the same method of treatment. It is therefore highly advisable at the outset to draw a line between--

(1) Grasslands required for grazing and for the production of fodder,

(2) Grasslands which are not required for fodder-production and which it is desirable to afforest,

seeing that the production of grass and production of trees are two distinct and more or less mutually incompatible objects which cannot as a rule be satisfactorily attained at the same time, on one and the same area.

Occasionally grasslands are of course required for purposes other than those defined above, e.g. for the production of munj fibre, of thatching grass, and so on, for each of which a more or less special treatment is required, but as a general rule the maximum production of the best quality of wood and fodder respectively is undoubtedly the most important object which we desire to attain by a judicious treatment of our forest grasslands.

A point of some importance consists in the fact that grasslands tend to become highly inflammable in the hot season and therefore greatly increase the danger of fire-damage in the adjacent woodlands. It is however possible to prevent such damage, (1) by successfully afforesting our grasslands and thus killing out the grasses or (2) by managing these areas chiefly with a view to satisfying the demand in respect of fodder production and grazing needs, in which case the old, inedible and inflammable grass is either removed by burning, or else is not allowed to accumulate, owing to the young grass being continually cut or grazed.

The suggestions which it has been possible to make regarding the treatment of the grasslands in the locality here dealt with and which are based mainly on the detailed study of the representative species described above, have therefore been arranged with reference to these main objects as below :-

\section{A.-Treatment with a view to Fodder-Production.}

99. The first point of primary importance consists in this that the robust hygrophilous, or markedly mesophilous, grass species are, as a rule, too coarse to yield good fodder and only the young shoots and young leaves, or the 
older shoots and leaves of the less vigorous individuals, of such species are consequently utilised to any considerable extent by cattle.

Typical species of this description are the common coarse savannah grasses Saccharum IIunja, Saccharum Narenga, Erianthus Ravenno and Imperata. The last, being probably the most valuable for fodder, may be taken as fairly representative of this class.

If this grass is allowed to develop undisturbed, the grasslands composed of it chiefly consist throughout the cold and hot season of a mass of immature culms each bearing several large mature leaves which are more or less dead and dry and useless for fodder while the still younger shoots are minute and inconspicuous. The presence of the old dead leaves not only makes it difficult for cattle to find the few young green shoots that do exist, or to obtain a mouthful of fodder free from a considerable admixture of unpalatable material, but seriously retards the development of the young shoots by interfering with the passage of moisture into the soil and with the access of light. Until the rains have well set in and the development of the young culms has well advanced the quantity of green material available on such grasslands is exceedingly small and in the rains the majority of it is too coarse to be palatable. On the other hand, if these grasslands are fired when the old leaves are thoroughly dry, about December, the young shoots usually start vigorous growth in January-February and a good supply of fodder becomes available from February to June. If the grasslands are well grazed throughout the rains and thereafter, the vigorous development of the plant and the production of the coarse unpalatable full-sized leaves necomes impossible and the grassland yields a practically perennial supply of slender culms and small green leaves. If it is impossible to check vigorous growth during the rains, fire should be annually employed to increase the fodder supply.

In the case of the majority of the coarse savannah grasses in the present locality and probably also in other parts of India, fire alone is rarely capable of killing out the species and is directly beneficial in clearing away inedible material, in enabling cattle to gain easy access to the young palatable shoots and in increasing the production and accelerating the growth of the latter at a season when fodder is usually scarce. The only coarse savannah species dealt with in this paper which is liable to be killed out by repeated early firing is Saccharum Munja when growing on dry sandy soil. In this locality at least one area exists near Bullawala where this has taken place and where a far more valuable fodder-grass, viz. Andropogon monticola, now occupies the ground, owing to the fact that it suffers less severely from fire damage.

In addition to the direct action of fire on the grass plants, also, we have to consider another important point, viz. the effect of fire upon the soil. It is obvious that any factor which decreases the water-content of the soil, ipso facto, renders a locality unfavourable for the vigorous growth of robust mesophilous and hygrophilous species and tends to produce conditions suitable for the growth of more xerophilous plants. 
This is exactly what fire really does and it appears to act in two principal ways :-

(1) By directly destroying the humus which may exist in the surface soil and by effectually preventing any further addition to the existing supply through the destruction of all dead leaves and organic débris.

(2) By altering the character of the clayey constituents of the soil in such a way that loam to a great extent loses its power of retaining water. The texture of the soil becomes coarser and percolation is increased.

The grassland known as Gola Tappar in the present locality which is shown in Plate $\mathrm{XL}$ is believed to be an instructive example of this drying action of fire on the soil. This grassland is believed to occupy ground which was at one time covered with Sal forest, the latter having been cleared for cultivation. The soil is a loam, apparently suitable for Sal and more or less similar to that in the adjoining Sal forest which surrounds the area on all sides, while Saccharum Narenga, the Sal-locality-indicator, is a common grass in the area. This Tappar is reported to have been regularly burnt for many years and the result is remarkable. Instead of a dense growth of the giant Saccharum Narenga which would naturally have been expected in such a locality we find a good deal of both Saccharum Narenga and Saccharum Munja, but only of very inferior vigour and dimensions, while more significant still, we find the xerophilous Andropogon contortus actually able to occupy considerable areas and to become dominant in a locality where it would, under ordinary circumstances, have been ousted by the far more vigorous competitors named. Experience elsewhere in similar soil has shown that fire is not likely to have here caused the poor growth of the Saccharum sp. noticed, by direct injury to the plants and both the species here flower freely which would not be the case if the direct fire damage was severe and most of the oneyear culms destroyed. It is therefore concluded that, in this case, the poor growth of the coarse savannah grasses and the unusual prevalence of the more xerophilous Andropogon is mainly due to the drying of the soil and that this area affords a good example of the power possessed by fires of replacing hygrophilous, or strongly mesophilous growth, by a xerophilous type of vegetation. It has often been stated that fires favour the development of coarse species and are injurious to the more valuable fodder grasses. From the above remarks, however, it will be seen that such a generalisation is impossible, that fire under certain circumstances can kill out a coarse, comparatively valueless, fodder-grass like Saccharum Munja and may cause it to be replaced by a more valuable fodder-species like Andropogon monticola and that, as a general rule, by its action in drying the soil, fire is able to produce conditions favourable for comparatively xerophilous species which are usually more valuable for fodder than the hygrophilous or strongly mesophilous grasses. In areas where the latter prevail it must I think be accepted that firing is, on the whole, decidedly beneficial in improving the fodder supply. Further than this, however, it is impossible to generalise for, when dealing with the xerophilous or less strongly mesophilous species, it is obvious that some are of more value as fodder than others and that some are avoided by cattle on account of their peculiar taste, odour, cutting leaves, [ 120$]$ 
hairs, barbs, and so on. Whether firing is, or is not, a beneficial treatment to adopt in grasslands of such species will depend entirely on the charactcristics of the particular species dealt with, on the nature of competing species, and on the conditions of the locality. Thus Andropogon contortus Linn., Andropogon foveolatus Del. and Andropogon annulatus Forsk. are probably all to be reckoned as xerophilous specics and all yield in conscquence fairly good fodder. The first, however, is often avoided by cattle on account of the characteristic masses of its long-awned and barbed fruiting spikelets and for this reason it is often considered of little value in India. It is, however, hardly correct to speak of this plant as a coarse species which is a term best reserved for the more robust hygrophytes and mesophytes and it should be noted that, apart from its peculiar fruiting spikelets, this species is a good fodder and Duthie writes as follows regarding it: "Largely used as fodder both before and after it has flowered, but chiefly when it is young and tender. * * On Mount Abu the pcople consider it the best fodder grass they have. * * In Australia it is looked upon as a splendid grass for a cattle run, as it produces a great amount of feed." It is undoubtedly a fact that this spccies frequently tends to increase in burnt grasslands, whereas in similar stations which are protected it has to give way, to a considerable extent, to such species as Andropogon foveolatus and Andropogon annulatus. An experiment initiated by Mr. R. S. Pearson some years ago in the Panch Mahals Division of Bombay and of which details have kindly been supplied to me has shown this to have nccurred in that locality, while in Dehra Dun a comparison of the grasslands known as Zabarkhet and Gola Tappar indicates that in protected areas Andropogon contortus is to a great extent replaced by Andropogon intermedius. The fact that Andropogon contortus tends to spread in burnt areas is probably due to the fruit being fire-resistant, on account of the very hard enclosing glumes.

Thus it will be clear that, while a generalisation, to the effect that fire is as a rule beneficial in areas where hygrophilous or coarse mesophilous grasses predominate, appears to be justifiable, we cannot proceed further to say that fire is as a rule beneficial with all species.

As regards local grasslands, therefore, it may be said that where Erianthus, Saccharum Narenga, Saccharum Munja and Imperata are dominant, early firing is as a rule decidedly beneficial so far as the fodder supply is concerned inasmuch as this (1) increases the quantity of palatable fodder available from these species themselves, and (2) either by directly injuring the plants themselves (as in the case of Saccharum Munja on sand), or indirectly by drying the soil, tends to replace these coarse species by less vigorous and generally more valuable fodder-grasses, such as Andropogon monticola on sand and Andropogon contortus on loam.

The value of Saccharum spontaneum for fodder is also, as a rule, probably increased by early firing which cleans the clumps of clébris and old culms and insures the production of a good supply of vigorous young shoots from the ground. In places where it cannot be easily fired owing to the wet conditions of its habitat and where vigorous growth during the

1 Fodder Grasses of Northern India by J. F. Duthie, p. 32

[ 121$]$ 
rains cannot be checked by grazing, the grass should be cut close to the ground in the cold season, as this will to a great extent have the same effect as fire, although of course it is a more expensive treatment.

Triraphis and Aristida are believed to be little used for fodder, but the young shoots would probably be of value during the period February to June and the removal of the old flowering culms by fire, or cutting, in the cold season would be advisable where possible.

As regards grasslands where valuable fodder-grasses are already the dominant species it is obviously advisable, as a rule, to let well alone and not to run the risk of favouring the introduction or extension of less valuable kinds by firing. On sandy soil where Andropogon monticola is already dominant firing may to some extent directly injure that species and may result in bringing in less desirable xerophilous species of Andropogon, Eragrostis and others. On loam where species like Andropogon annulatus, Andropogon intermedius, Andropogon foveolatus, Iseilema, and others are dominant, firing very frequently results in increasing the proportion of Andropogon contortus and it is clearly a question for local officers to decide, in the light of local prejudice and demand, whether or not this is desirable.

On grasslands where valuable perennial species like Andropogon monticola are already dominant, it is clear that the best treatment to apply, in order to obtain the maximum of good fodder with a minimum of damage to the plants, consists in protecting the areas from fire and grazing and in cutting the grass when flowering is just commencing. Grass so cut should be made into hay, or silage, and the cattle stall-fed. Heavy grazing not only directly weakens the plants by continually depriving the growing culms of their green leaves more or less completely, but considerable damage is done by the treading of cattle in the way of destroying young shoots and also by treading down the soil around the plants, and thus checking their outward growth. In sandy soil the rhizome-branches are often found to be exposed above the ground surface on account of this injurious action and in loam the soil becomes injuriously hardened and compacted.

\section{B.-Treatment with a view to Afforestation.}

100. As regards the question of afforestation,

the local grasslands must first be divided into-

(1) Those in which the vigorous growth of most woody plants is made impossible by frost, the latter being in this case the factor of dominant importance.

(2) Those where the frost damage is not severe and where woody plants can establish themselves.

As examples of the first we may take the areas locally known as Zabarkhet in Lachiwala Range, Gola Tappar in 'Tirsal Range (see Plate XL) and Koilpura Tappar in Ganges Range. 
Examples of the second are Kanswala Tappar and parts of Palasi Tappar in Lachiwala Range.

Grasslands of the first class appear to owe their characteristics mainly to the fact that they are surrounded on all sides by dense forest, on account of which free circulation of air is impossible. These areas are therefore subjected to intense heat by solar radiation during the day and hot scason and to great cold by terrestrial radiation during the night and cold season. The natural result of these influences is to diminish the water-content of the soil and to cause great damage from frost, i.e. to create conditions only suitable for the development of xerophilous, or the less mesophilous, and frost-hardy species.

101. On the loamy soil prevailing in Zabarkhet, which is fire-protected, the grass which should be dominant is the coarse mesophilous Saccham Narenga. The latter, however, is here seen to grow vigorously, as a rule, only near the edges of the grassland where the shade of the surrounding forest keeps the soil moist, while, in the most exposed portions of the area, the far less mesophilous Andropogon intermedius tends to become dominant.

In Gola Tappar which is regularly fired, but which lies higher and where there is possibly more air circulation, the drying action is intensified by fire and here again Saccharum Narenga is seen to be of inferior vigour and dimensions. Here, however, probably on account of its fire-hardy fruiting spikelets, Andropogon contortus to a considerable extent takes the place of $A$ ndropogon intermedius.

Grasslands of this type appear, as a rule, to have been caused by clearings which were made in the forest for the purposes of cultivation and then abandoned.

In those grasslands where, owing to the small size or shape of the area cleared, or to the configuration of the ground, a certain amount of shade is derived from the surrounding forest, or where a few trees were left scattered over the area at the time of clearing, the effect of such shade in increasing the water content of the soil is very marked. As already noted above, Saccharum Narenga is vigorous near the edges of Zabarkhet, while a walk through Gola Tappar only showed a single vigorous plant of the moisture-loving Erianthus Ravennce which was situated beneath the ample shade of a large tree of Ficus bengalensis. This prevalence and increased vigour of strongly mesophilous grasses in these areas near the shade of trees is very marked, has been frequently noticed, and is a very striking illustration of the value of shade under these conditions in the way of increasing the water content of the soil.

102. As regards the question of frost, it should first be noted that low temperature is believed to be injurious to woody plants in two principal ways :-

(a) Indirectly by desiccation. When the soil temperature falls below a certain point the roots are no longer able to absorb the necessary supplies of water. While 
the roots are thus inactive, the leaves may be actively transpiring moisture under the influence of bright sun-light and dry air-currents. The leaves and branches of woody plants may thus become completely dried up and killed, in the same manner as in a case of drought.

(b) Directly by the low temperature of the air in contact with the aerial leaves, twigs and branches.

The first mode of action can often be recognised in the forest by the fact that those aerial portions of a plant tend to be injured first which are furthest removed from the water supply ascending from the roots, i.e. the base of the leaf and those parts of the lamina nearest the main nerves are often found to be uninjured and green when the rest of the leaf is shrivelled and brown, while the terminal twigs and branches tend to die back first.

On the other hand, the second mode of action can often be recognised by the fact that those parts of the plant are most injured which are in contact with the coldest air, irrespective of their position at the base or apex of the plant. Thus those leaves or portions of leaves which are shaded by neighbouring leaves and thus protected from radiation will be often found to have escaped damage when the rest of the leaves have been killed. In grasslands unrestricted radiation tends to produce a layer of cold air just at, or immediately above, the level of the grass and that radiation is chiefly responsible for the frost damage done to woody plants in the grasslands now under consideration is often clearly indicated by the fact that the leaves and twigs situated just at, or immediately above, the level of the grass tend to be damaged first, although they are not necessarily at the apex of the plant.

103. With reference to the treatment of this type of grassland, therefore, it is obvious that we may either try to reduce radiation which is chiefly responsible for the failure of Sal to establish itself in areas where the soil is generally suited for it, as indicated by the prevalence of the grass Saccharum Narenga, or we must introduce frost-hardy and xerophilous species which are able to thrive under the conditions of the habitat.

The injurious action of radiation might be modified-

(a) By clearing lines through the surrounding forest and thus improving the circulation of air.

(b) By irrigating and thus keeping the soil moist which would result in increasing the quantity of water vapour in the air and thus in decreasing radiation.

On the other hand, if these measures are impracticable, the most suitable indigenous frost-hardy and xerophilous species for afforesting these grasslands is almost certainly the khair, Acacia Catectu. Another species which would probably be of value in establishing woodland in such places is Zizyphus Jujuba.

Two exotic species which it is believed might be successful are Cinnamonum Camphora and Eucalyptus citriodora both of which were observed to successfully survive the excep:tionally severe winter of 1904-05 in frosty grasslands in this locality. 
Once these species or some of them have been established, a shrub which it is believed would be of great value if introduced as an underwood is Adhatoda Vasica. This plant is xerophilous although a strong shade-bearer and on account of its power of increasing the humus ccitent of the soil it would probably help to establish soil moisture conditions suit. able for sal and thus facilitate the ultimate introduction of the latter, where this is considered advisable.

104. As regards those grasslands where frost damage is not severe it should be remembered that where--

Saccharum Munja is dominant the locality is usually suitable for Dry Miscellaneous Forest,

Saccharum Narenga is dominant the locality is usually suitable for Sal Forest,

Erianthus Ravenne is dominant the locality is usually suitable for Moist Miscellaneous Forest,

and that careful protection from fire and grazing will, as a rule, result in naturally replacing these types of grassland by forest of the parallel type. A cacia Catechu has been seen establishing itself naturally in thickets of Saccharum Munja, Mallotus and Cedrela have similarly been seen ousting Erianthus and it is believed that Sal can do the same with Saccharum Narenga, but artificial sowings would naturally hasten this result.

105. The study of the œcology of Sal has only recently been commenced at Dehra Dun and owing to the want of necessary staff and appliances it has only been possible to carry out a few preliminary and comparatively rough experiments for the purpose of determining the factors favourable for the establishment of Sal reproduction. A full account of these experiments is beyond the scope of the present paper and this will be published separately, but it is interesting to note that so far as they go these experiments show-

(a) That in this incality a number of sal seedlings die back in September-December owing to the rapid drying of the soil after the close of the rains. This injurious action is most marked on sand, less so on stiff loam and least in garden soil which contained a considerable admixture of humus. There had been no frost when this dying back was noticed and where the seedlings on these three classes of soil were regularly watered they did not die back.

(b) That Sal is markedly sensitive to the intensity of light. The leaves are coloured red when young and even when mature they possess considerable power of movement frequently turning their edges to intense light and the upper surface of the lamina to diffuse illumination.

That, in this locality, seedlings grown in stiffish loam, similar to that on which most of the local sal forests are found, develop more successfully [as judged independently by (i) the percentage of stems which die back and by (ii) the air-dried weight of the best stems which survive] when provided with 
overhead shade and diffuse lateral illumination than when grown in the open with no shade.

(c) That sal is decidedly sensitive as regards soil-aeration and water-logging proves rapidly fatal.

These results therefore show that sal is only likely to establish itself on well-drained soil which is not subject to water-logging and that in this locality any factor which reduces the humus content of the soil, or which tends to increase the loss of moisture from the soil by evaporation, tends to retard the establishment of sal reproduction.

The burning of grasslands which it is desired to ultimately afforest with sal therefore is obviously injurious owing to the destruction of all humus and organic débris while on the other hand the introduction, where possible, of plants like Eugenia operculata, Adhatoda and Mallotus into these areas will almost certainly accelerate the establishment of sal owing to their power of increasing the humus content of the soil, their shade being also to some extent beneficial.

106. It must of course be understood that the above remarks apply to the locality more particularly considered in this paper and it is obvious that the conditions prevailing here and in the Sal forests of Central India are very different from those of some of the Sal tracts of Bengal and Assam where the tree has. extended into, or close to, the hygrophytic Zone of the tropical evergreen forest. In such places the dominant factor is frequently not lack of sufficient soil moisture, but the presence of more vigorous competitors, and it is possible that fires, by reducing the water-content of the soil, may be beneficial to the Sal by rendering the conditions less favourable for the vigorous development of its injurious hygrophilous competitors. In these localities, also, insufficient aeration of the soil may in some cases be responsible for the unsatisfactory growth of Sal seedlings and here again firing would probably be beneficial. 


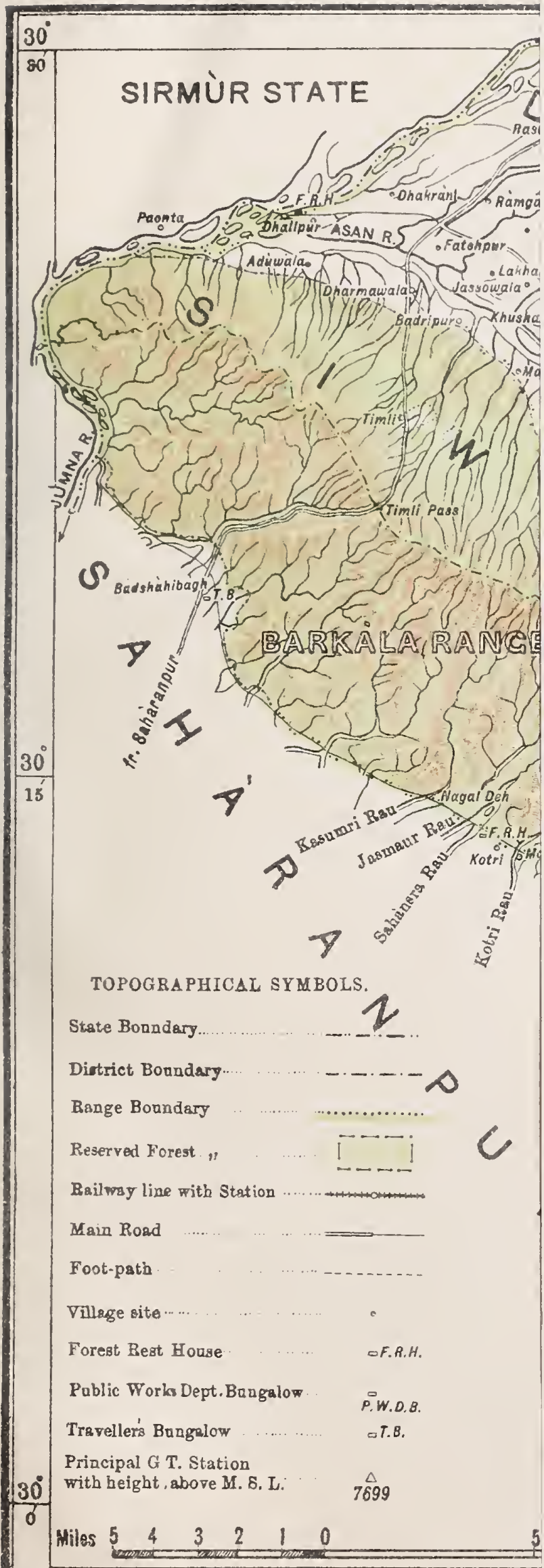

Complled in the Forest Map Ottice by A. Descubes Esqr. O.C. Forest $N$ Major J.M. Bum R,E. O. C. Forest Map Offico. Pubiisned in

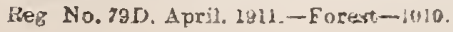


1 


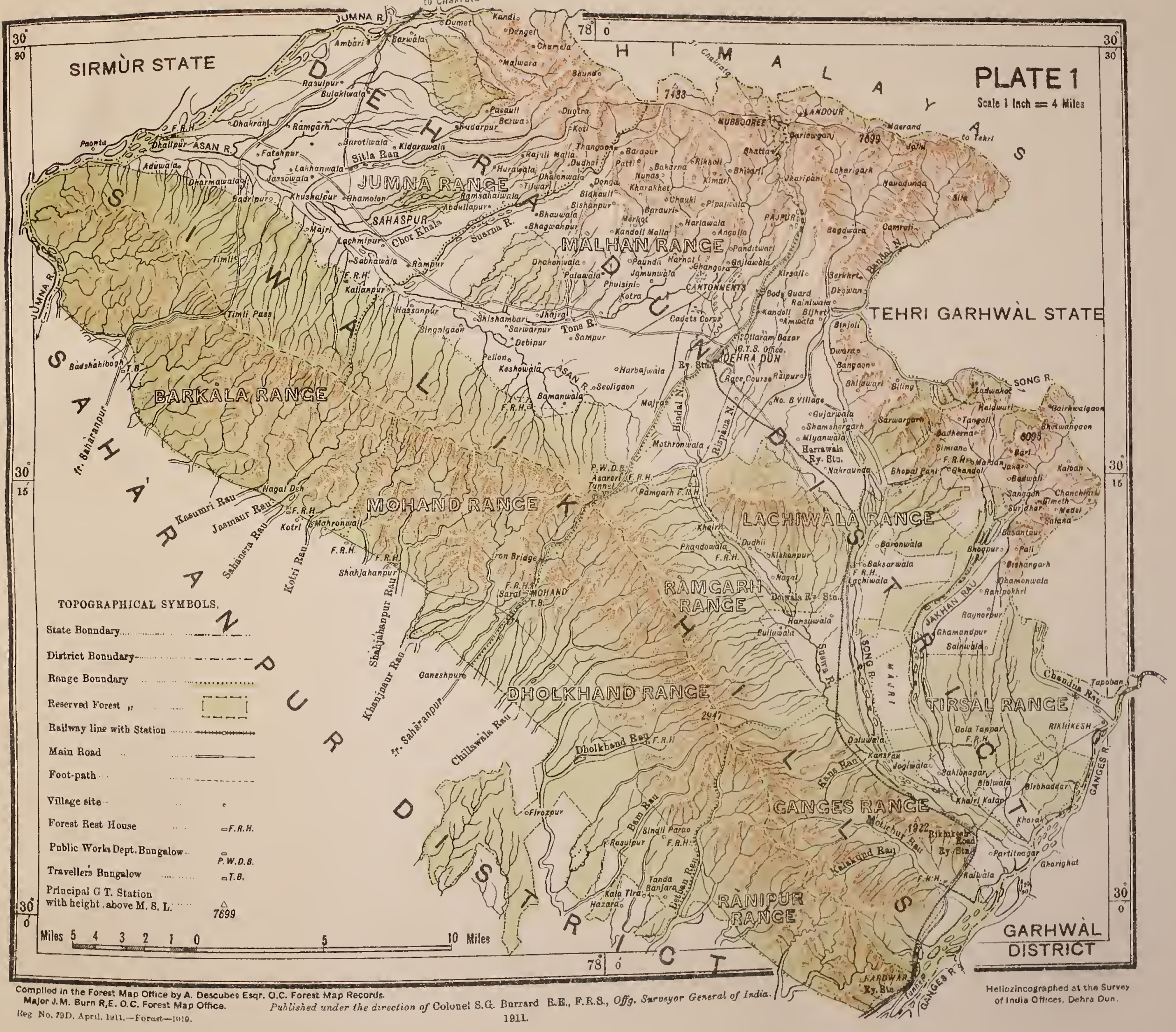






\section{Explanation of Figures.}

\section{Plate II.}

Fig. 1. Aristida cyanantha the dominant species, with scattered plants of Saccharum Munja, in dry gravelly bed of torrent near Jhajra which flows southwards into the Tons River. In the background is seen a line of Saccharum Munja occupying the sandy deposits on the banks of the Tons River.

Photograph taken 18th October 1909.

"2. A ristida cyanantha the dominant species, with scattered plants of Saccharum

Munja, showing the Tons River in the background with Saccharum Munja the dominant species on the sandy deposits on its banks.

Photograph taken 21st October 1909. 


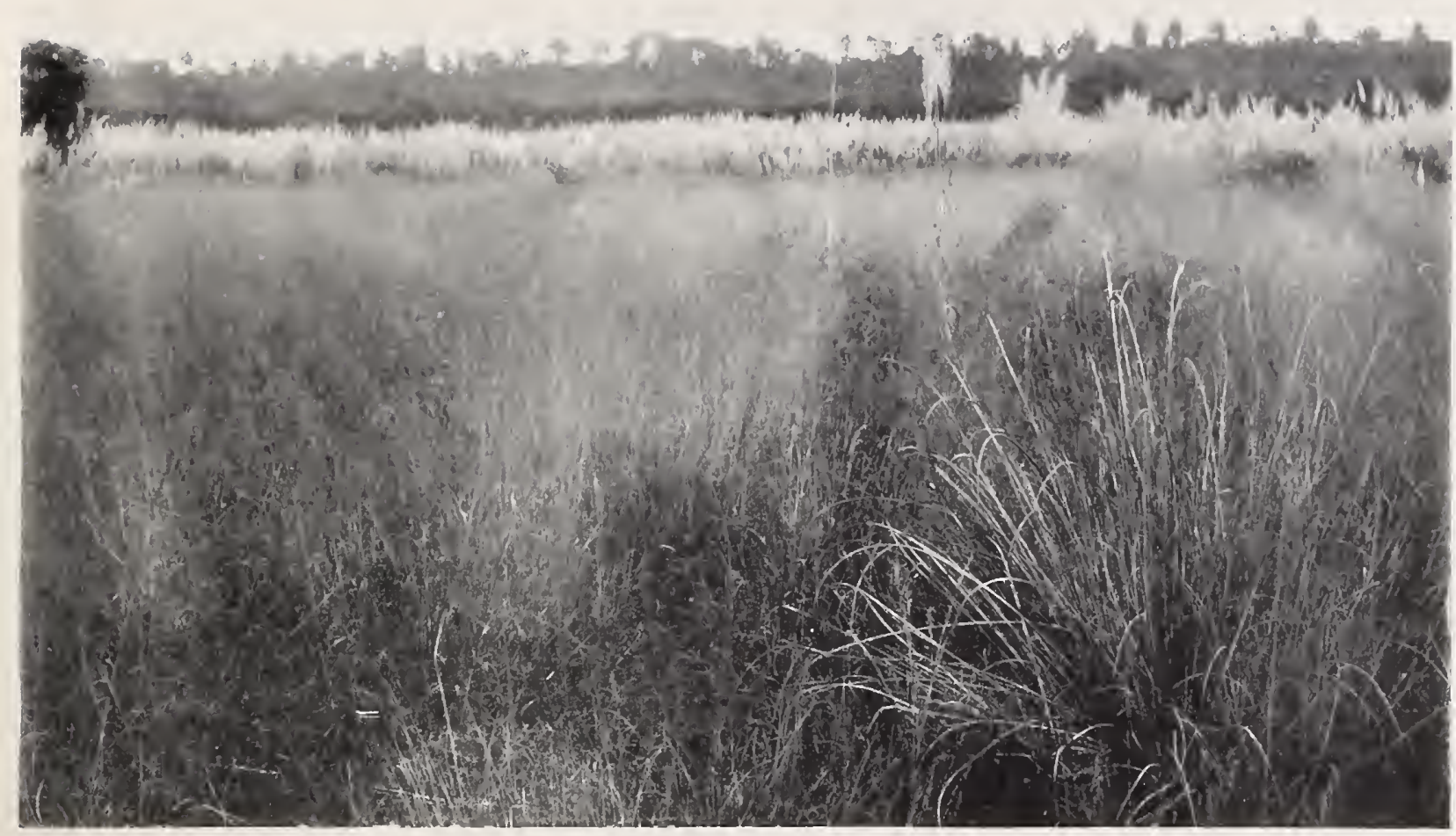

Fig. 1.

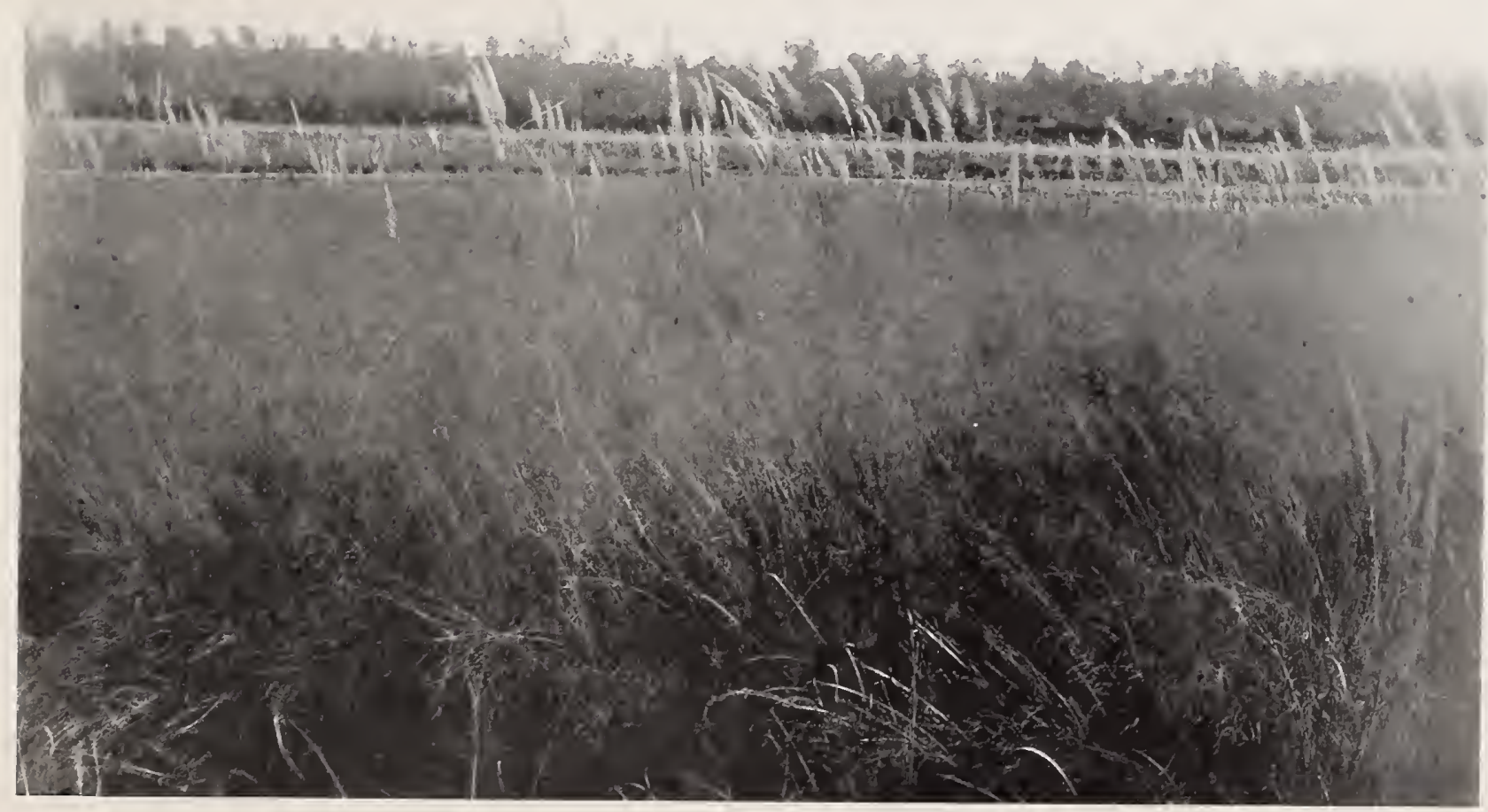

Fig, 2. 


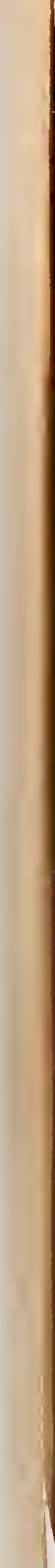





\section{Explanation of Figures.}

\section{Plate III.}

Fig. 1. In the foreground a portion of the bed of the Tons River below Jhajra. In the background the Siwalik Hills. Between these lies the Asan River.

The sandy deposits on the banks of these large streams constitute an extensive savannah of Saccharum Munja.

Photograph taken 18th October 1909.

, 2. The Asan River below Jhajra. On the water-logged area at the water's edge Saccharum spontaneum var. nepalense is dominant. The high well-drained ground in the background, on the contrary, is held by Saccharum Munja.

Photograph taken 21st October 1909. 


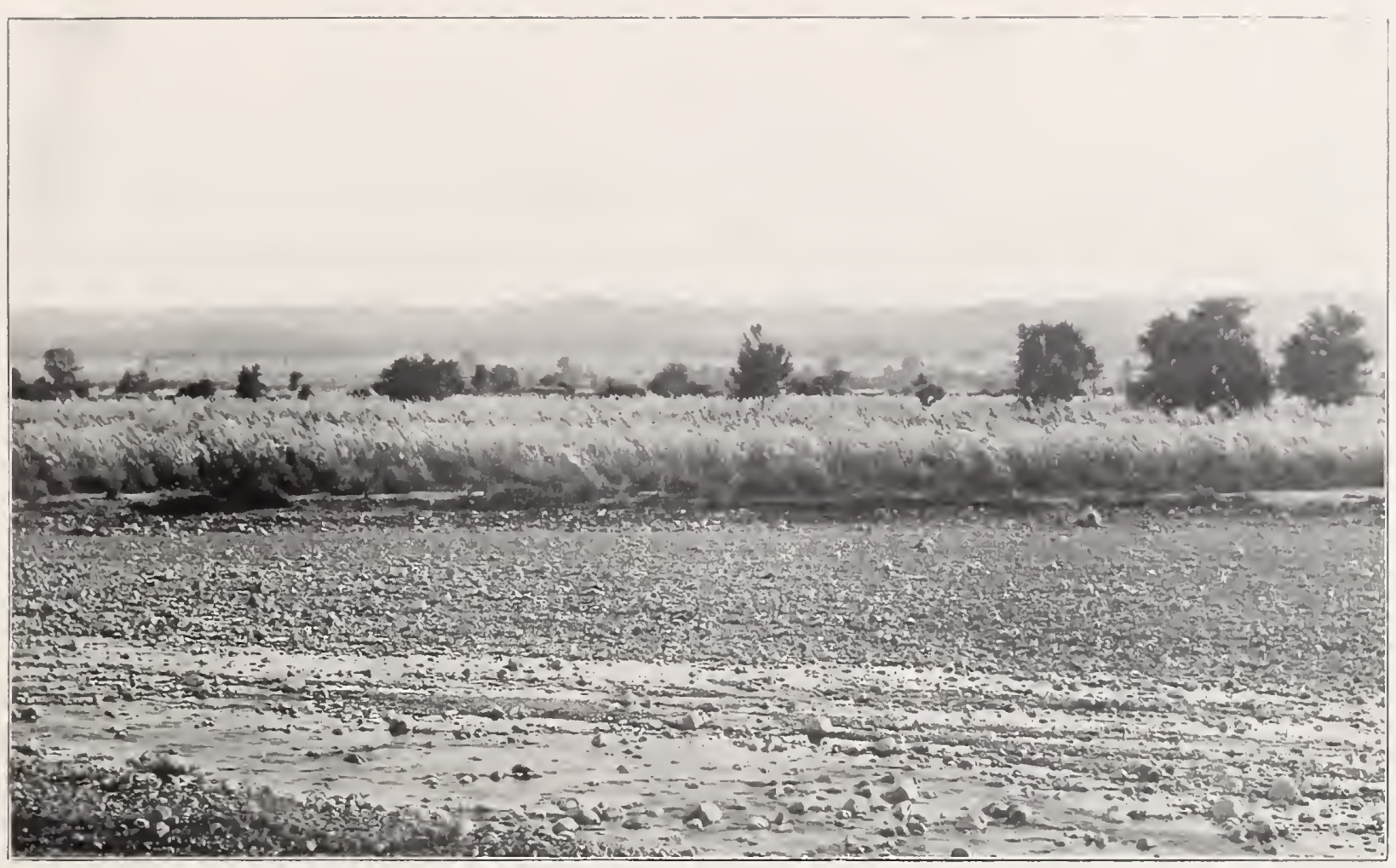

Fig. 1.

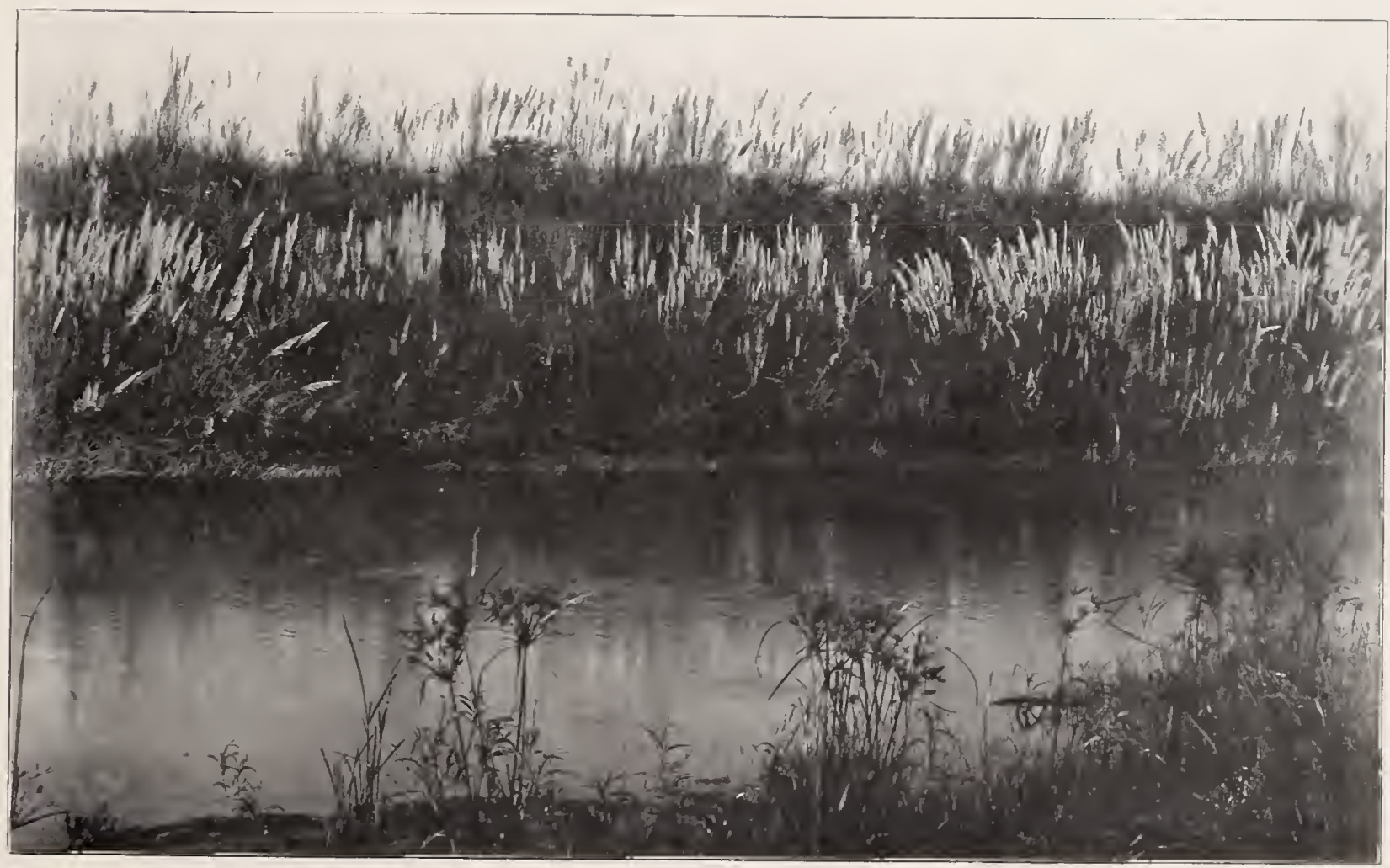

Fig. 2. 



\section{Explanation of Figures.}

Plate IV.

Fig. 1. Triraphis madagascariensis dominant on sandy bank of stream on edge of Sal forest near Kansrau.

Photograph taken January 1910.

"2. Triraphis madagascariensis with Aristida cyanantha in dry gravelly torrentbed on edge of Sal forest near Kansrau.

Photograph taken January 1910.

On the right in the foreground are seen some bent and broken twigs of Orthanthera viminea. 


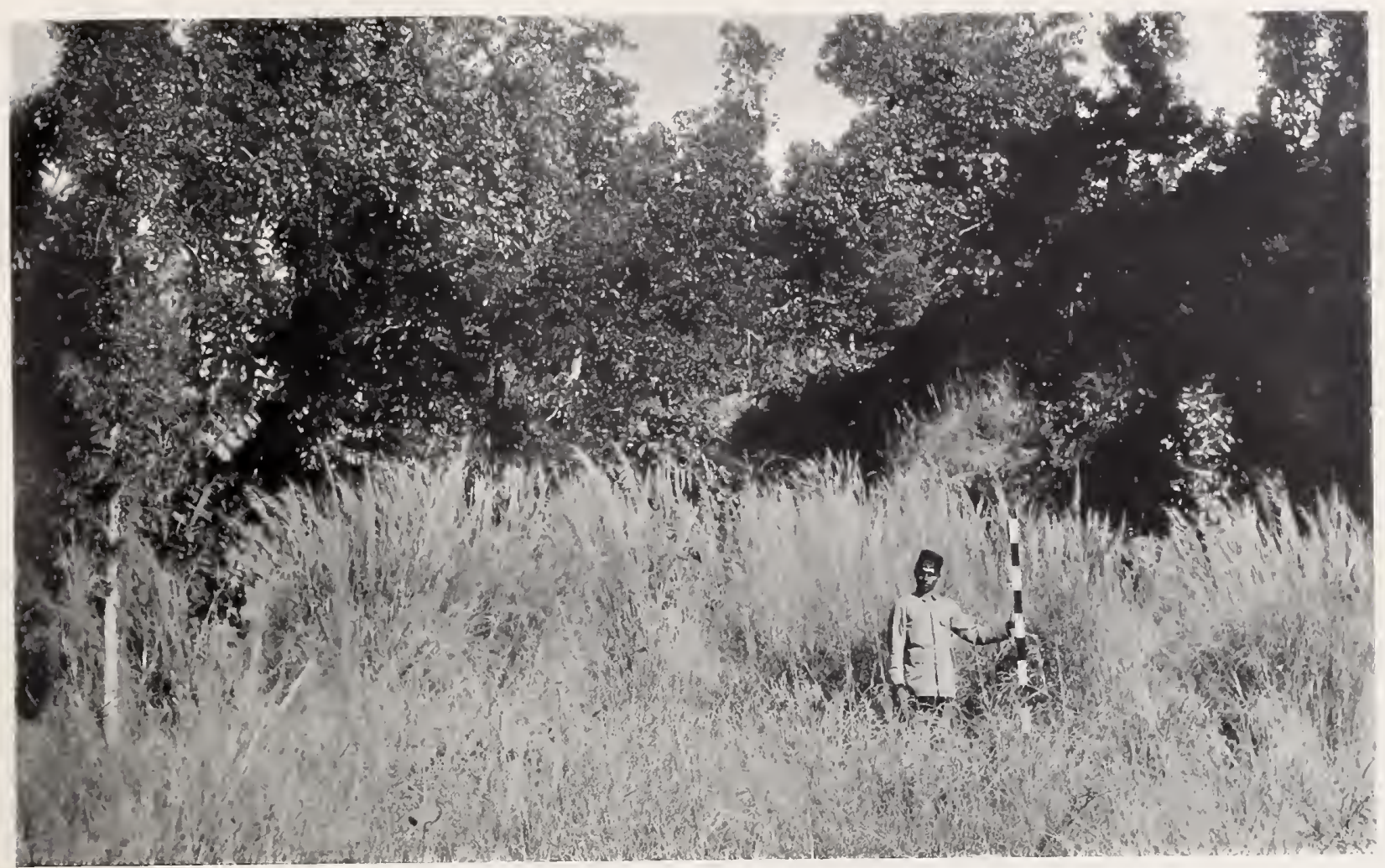

Fig. 1.

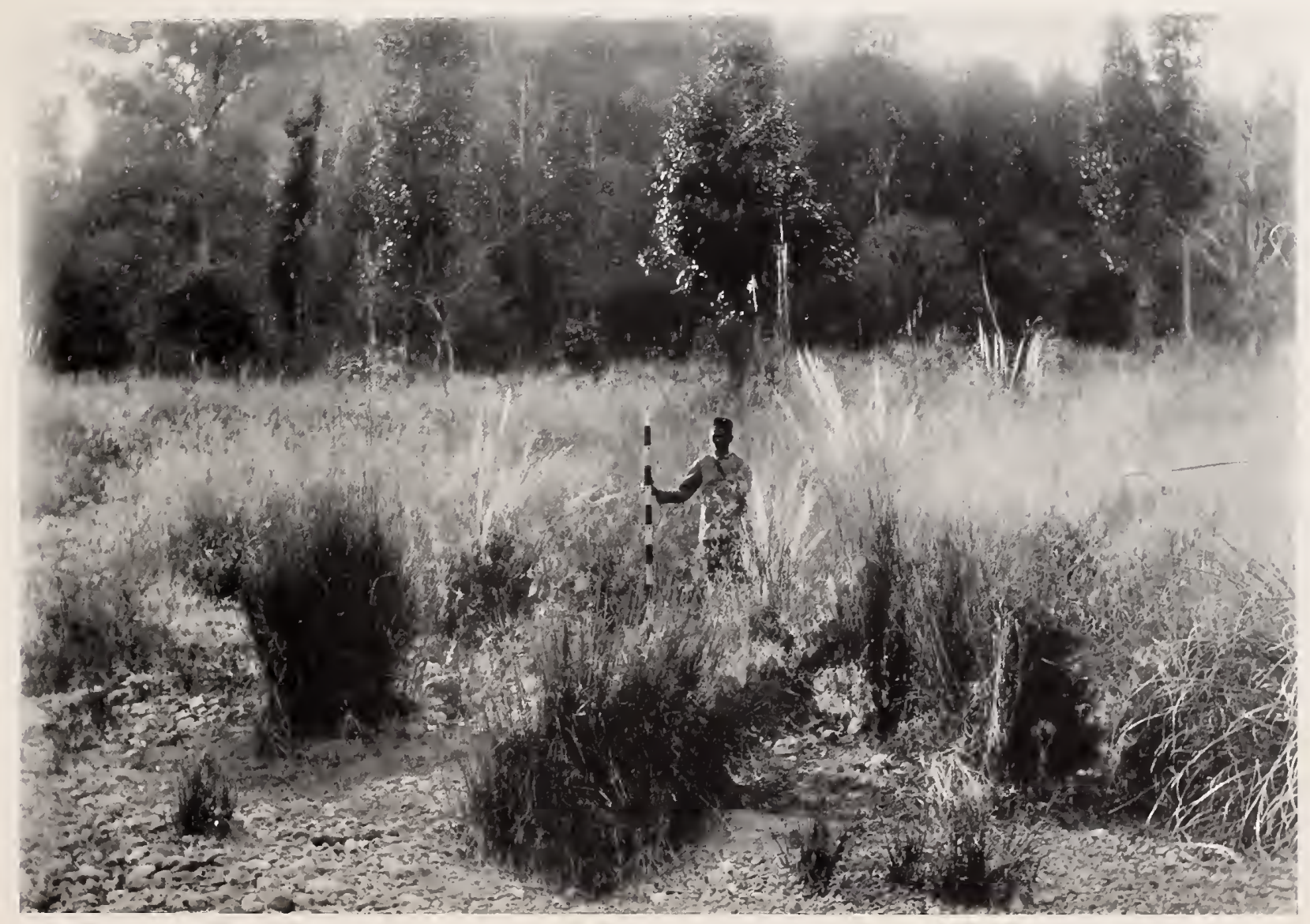

Fig. 2. 



\section{Explanation of Figures.}

\section{Plate V.}

Fig. 1. The Song River above Lachiwala with the Himalayas in the background, showing a patch of A cacia Catechu forest established on an island of boulders and sand.

On the edges of the forest Saccharum Munja and Saccharum spontaneum (tufted sand-form) can be seen. Under the Acacia is some undergrowth of Adhatoda Vasica.

Photograph taken January 1910.

" 2. The Song River below Doiwala showing Dry Miscellaneous Forest on deposits of boulders and sand. The forest consists of Bombax malabaricum, Odina Wodier, Acacia Catechu, Bauhinia racemosa, Dalbergia Sissoo, Grewia oppositifolia, Moringa pterygosperma (now flowering and conspicuous), Stereospermum suaveolens, Egle Marmelos and Cassia Fistula.

In the undergrowth are Calotropis procera, Murraya Koenigii, Zizyphus Jujuba, Randia dumetorum and Adhatoda Vasica.

On the edge of the forest are Saccharum Munja and Saccharum spontaneum.

Photograph taken January 1910. 


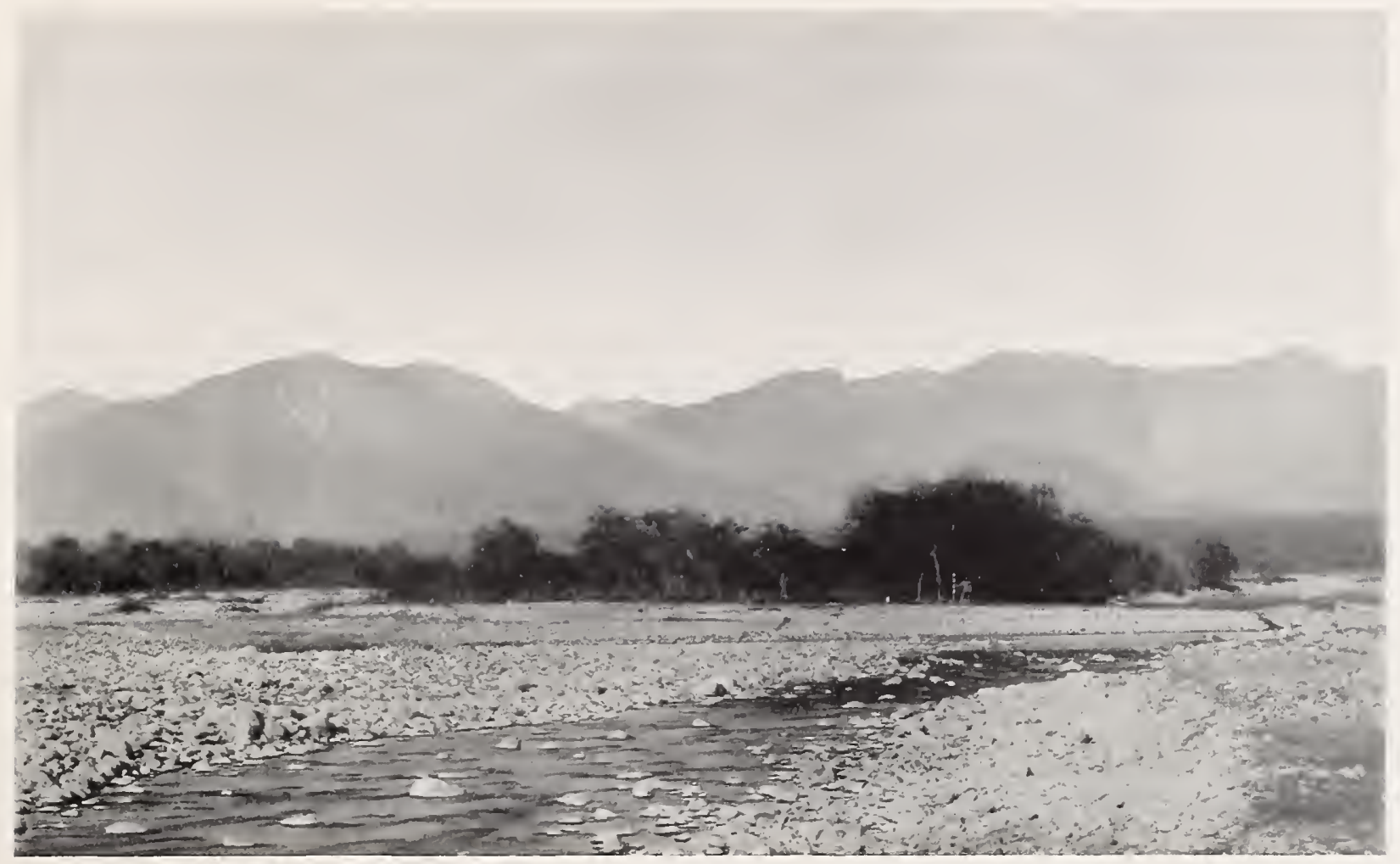

Fig. 1.

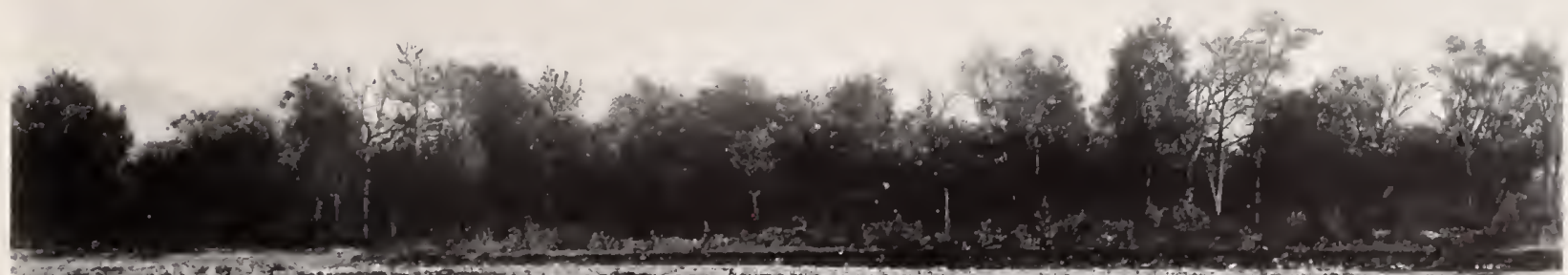

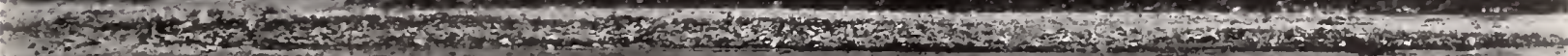

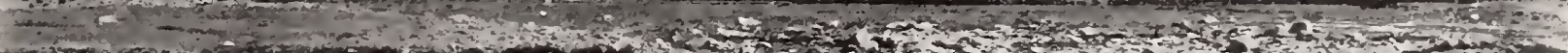

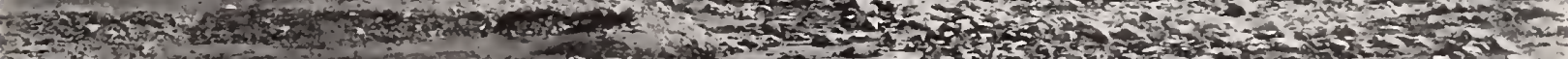

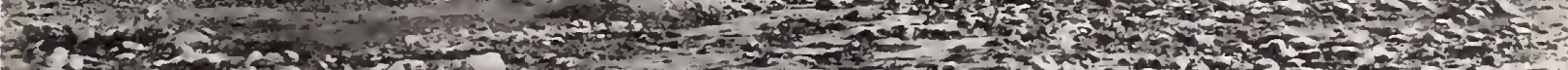

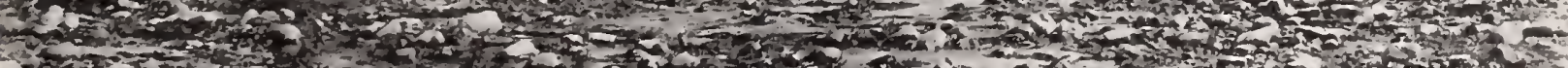

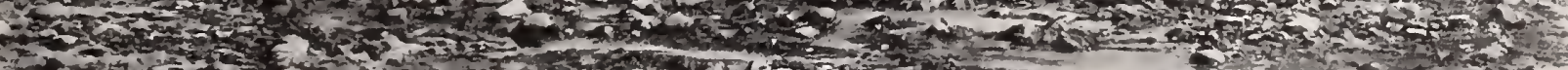

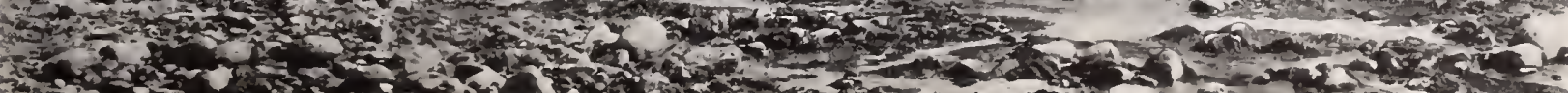





\section{Explanation of Figures.}

Plate VI.

Erianthus Ravennce on shady bank of irrigation canal below Lachiwala.

The water-logged soil at the water's-edge in the foreground is occupied by Coix Lachryma-Jobi and Saccharum spontaneum var. nepalense.

On the slightly higher ground behind is Erianthus Ravennoe. The trees are Sapium sebiferum, Trewia nudiflora, Mallotus philippinensis, Salix tetrasperma, Bombax malabaricum, and Cedrela Toona.

Photograph taken 31st October 1909. 


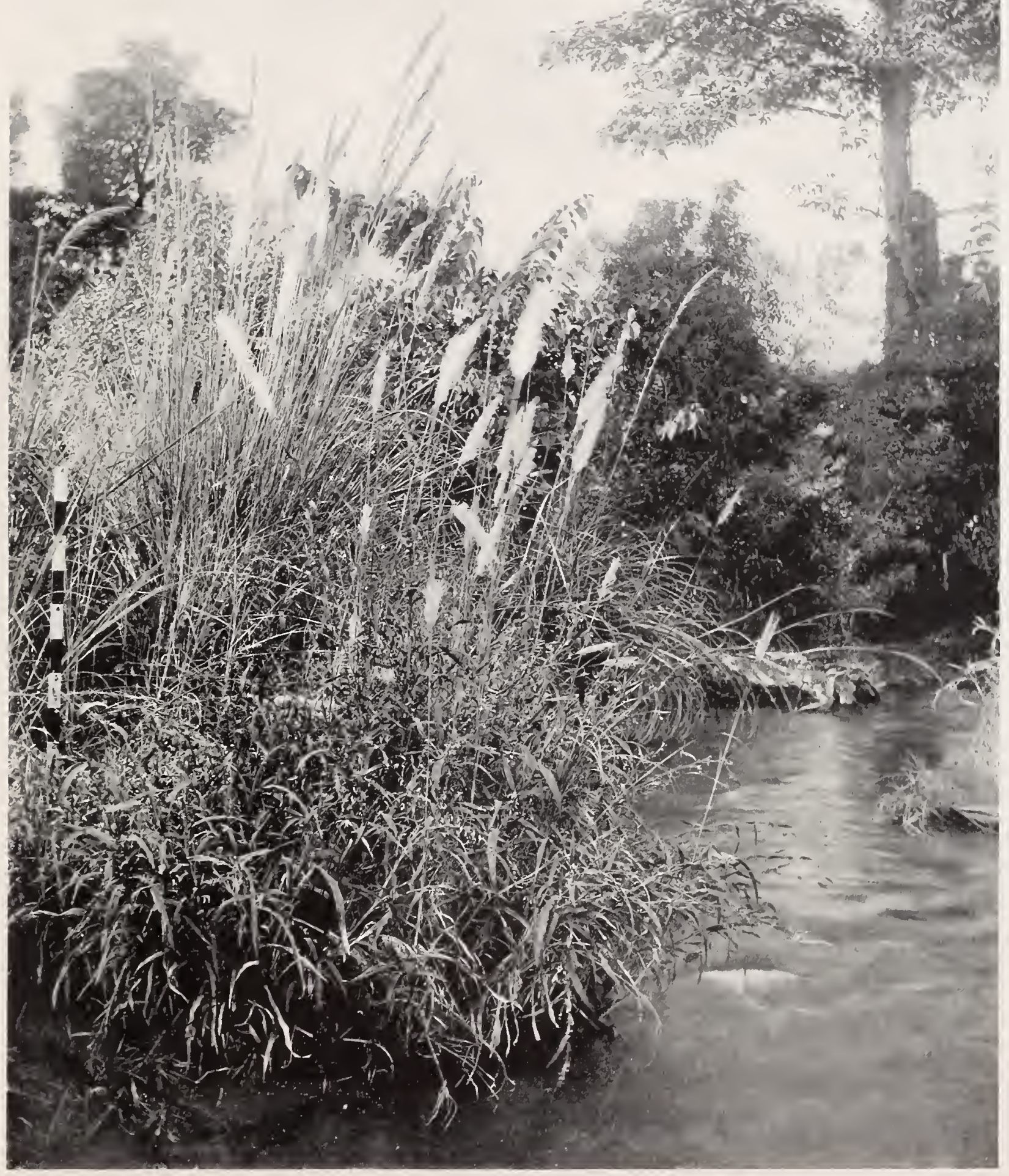





\section{Explanation of Figures.}

\section{Plate VII.}

Erianthus Ravenno associated with young trees of Mallotus philippinensis, Cedrela Toona and Bombax malabaricum near Lachiwala.

Photograph taken 31st October 1909 


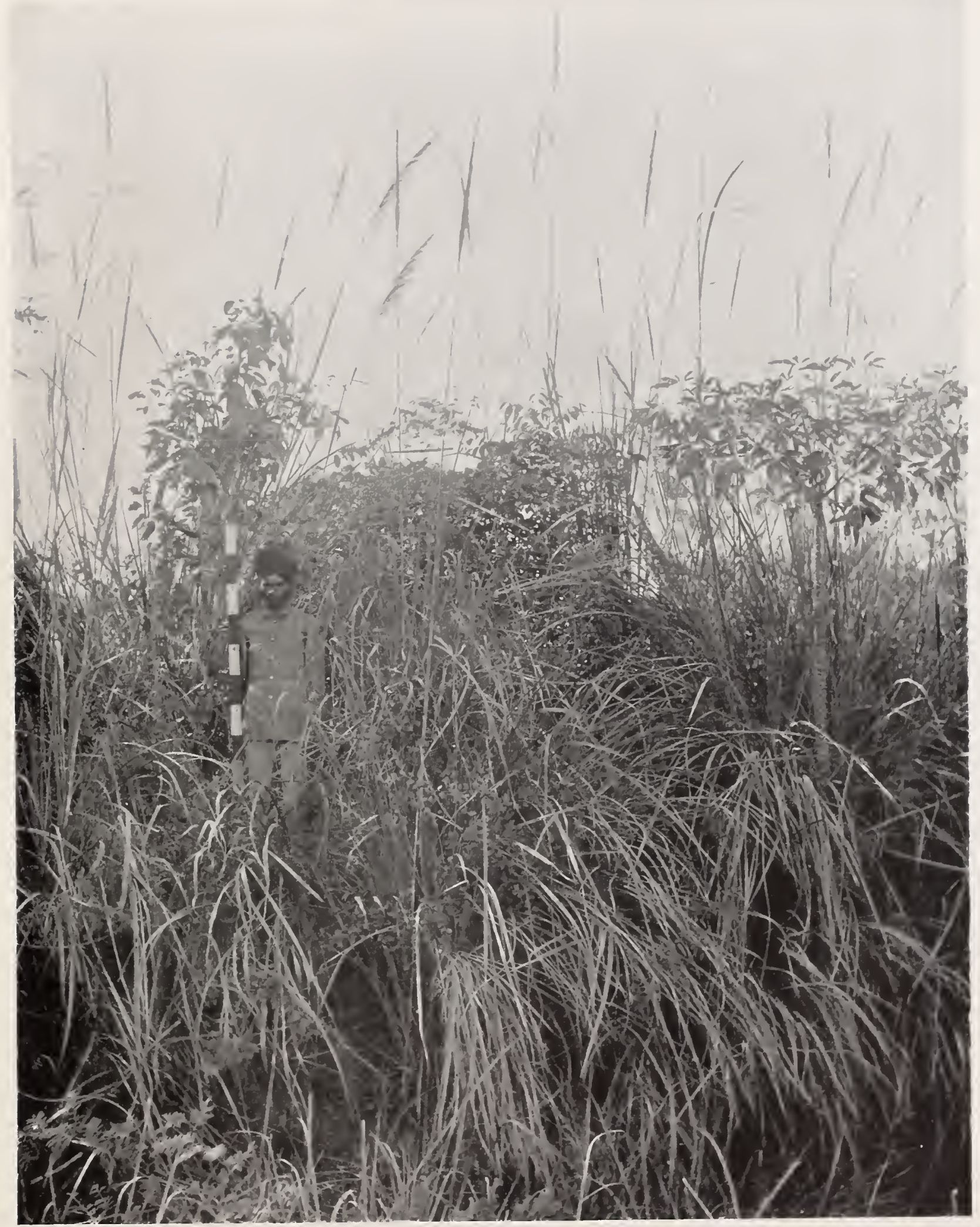





\section{Explanation of Figures.}

\section{Plate VIII.}

Erianthus Ravennoe dominant in narrow clearing made on account of the railway line in Moist Miscellaneous Forest near Lachiwala.

Photograph taken 31st October 1909.

The branches of the younger panicles are still spreading but the majority of the panicles are fruiting with erect branches. On the left is seen a panicle which has dried prematurely owing to the culm having been attacked by a larva.

Photograph taken 31st October 1909. 


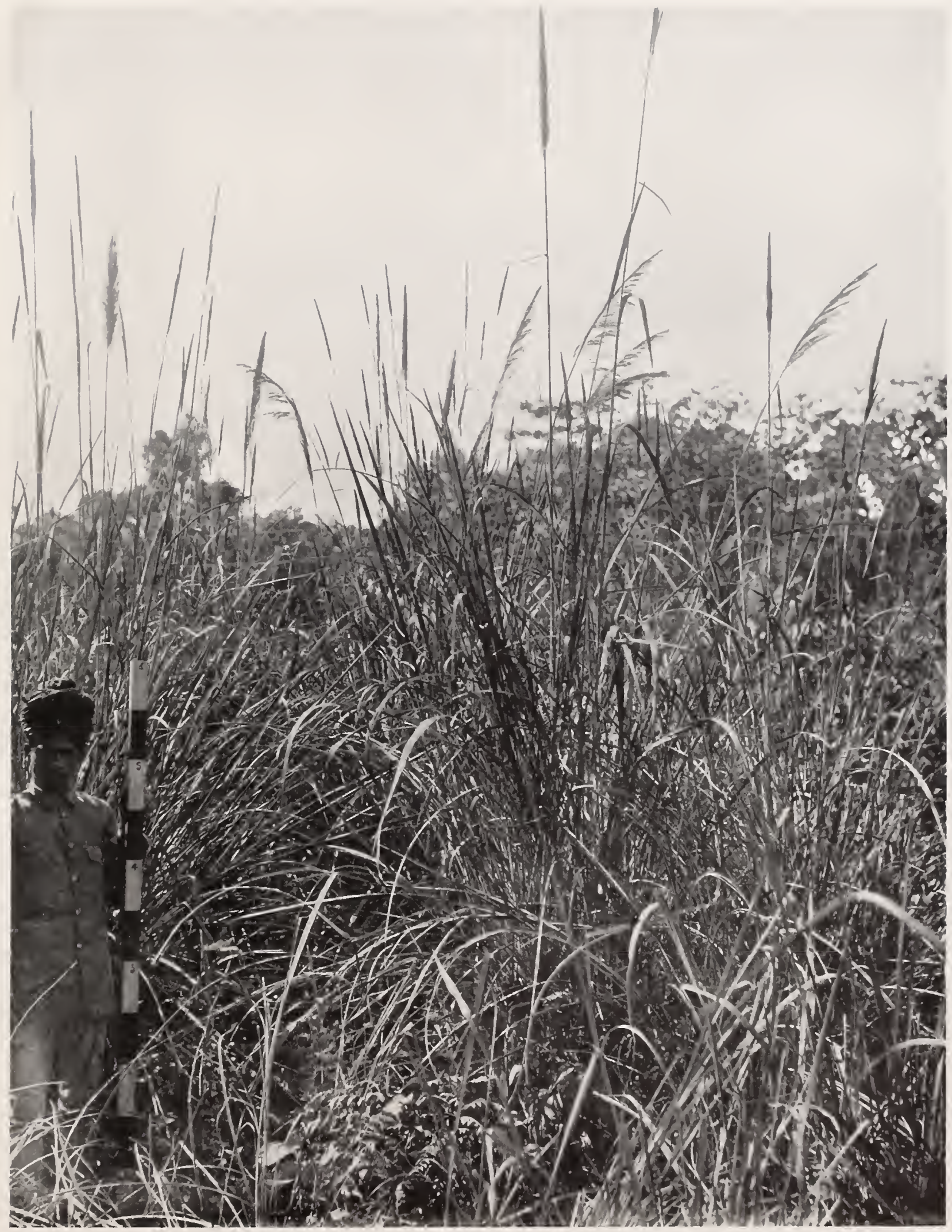


. 


\section{Explanation of Figures.}

Plate IX.

Fig. 1. Erianthus Ravennce in Moist Miscellaneous Forest near Karisrau. The trees are Stereospermum suaveolens, Celtis australis, Bombax malabaricum, Ehretia acuminata and Cedrela Toona.

"2. Erianthus Ravenna in Moist Miscellaneous Forest near Kansrau. The trees are Dalbergia Sissoo, Gmelina arborea, Kydia calycina, Cordia Myxa and Putranjiva Roxburghii.

Both these photographs taken January 1910. 


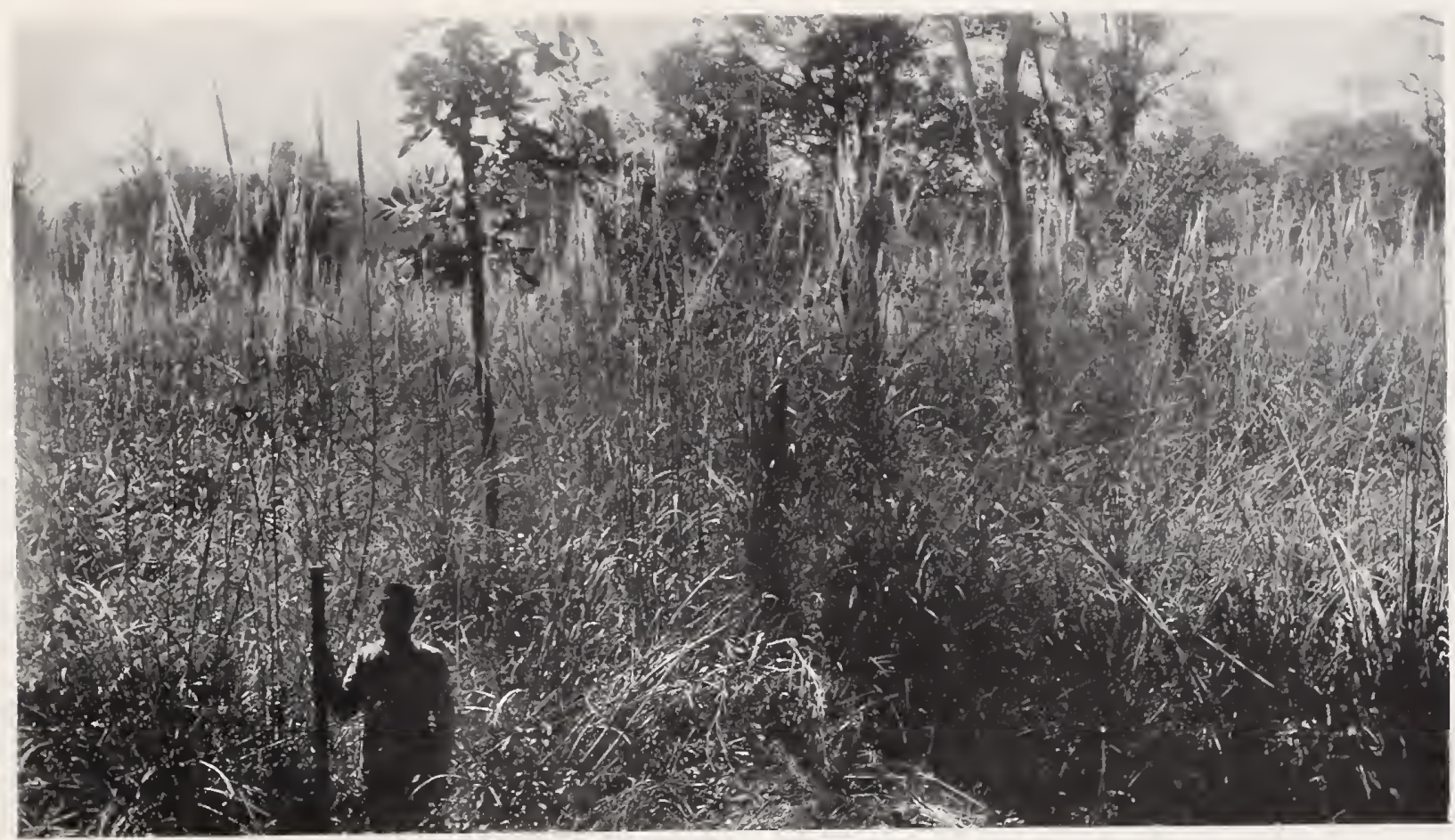

Fig. 1.

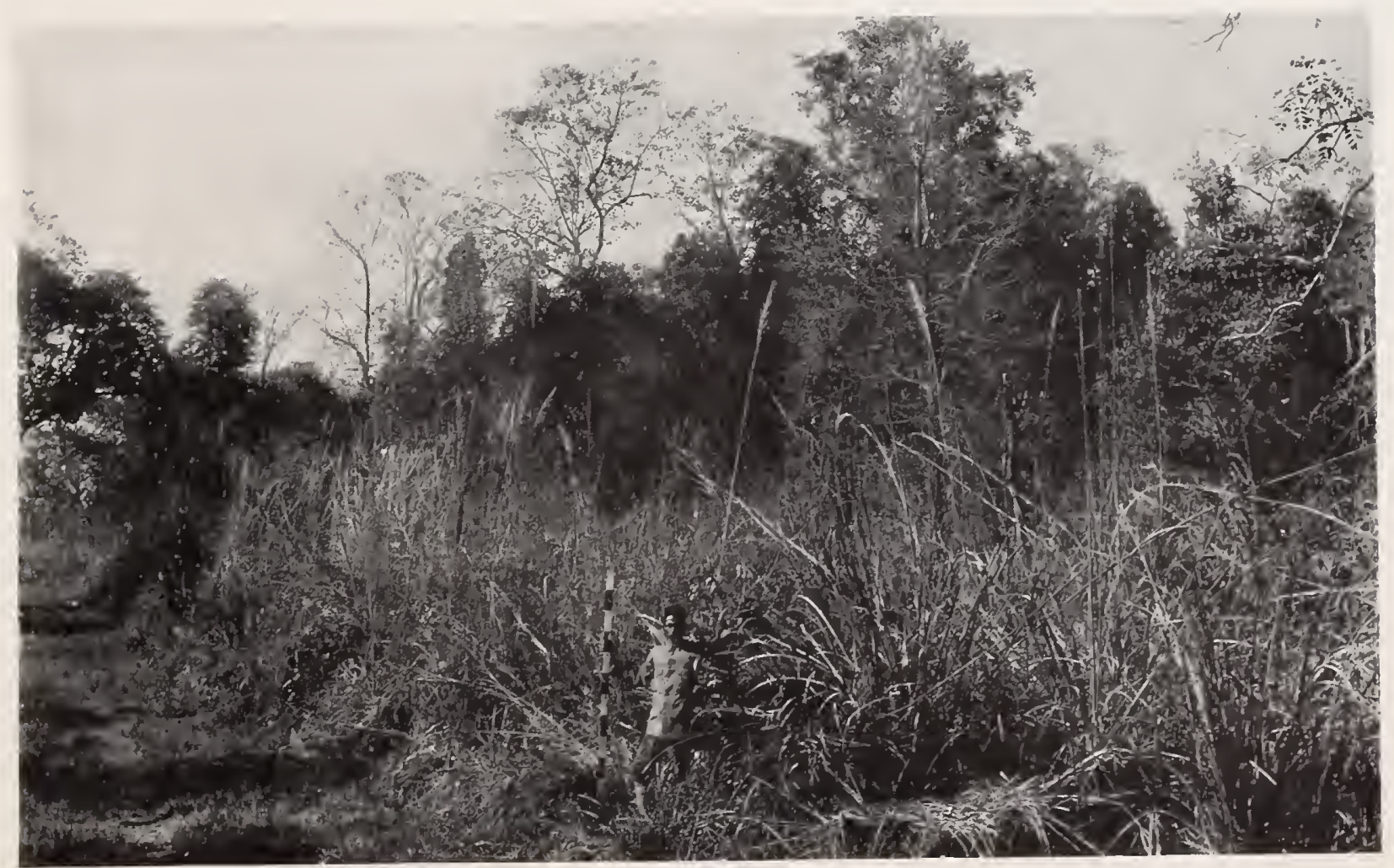

Fig. 2. 

- 


\section{Explanation of Figures.}

\section{Plate X.}

Fig.1. Erianthus Ravennce in Moist Miscellaneous Forest near Kansrau. The trees are Odina Wodier, Butea frondosa, Mallotus philippinensis, Garuga pinnata, Gmelina arborea, and Terminalia tomentosa.

:2. Erianthus Ravennce in Moist Miscellaneous Forest near Kansrau. The trees are Mallotus philippinensis and Cordia Myxa.

Both these photographs were taken January 1910. 


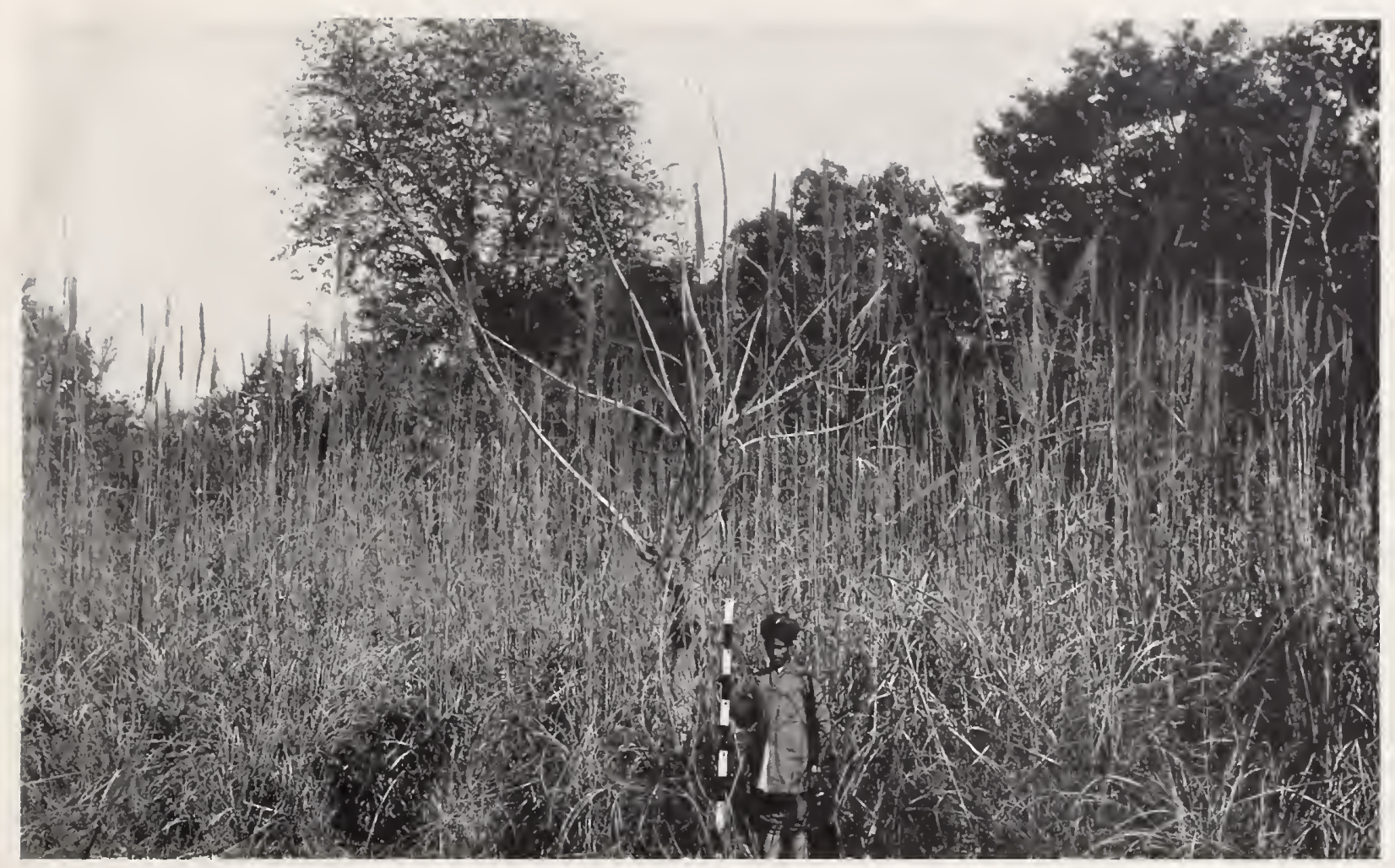

Fig. 1,

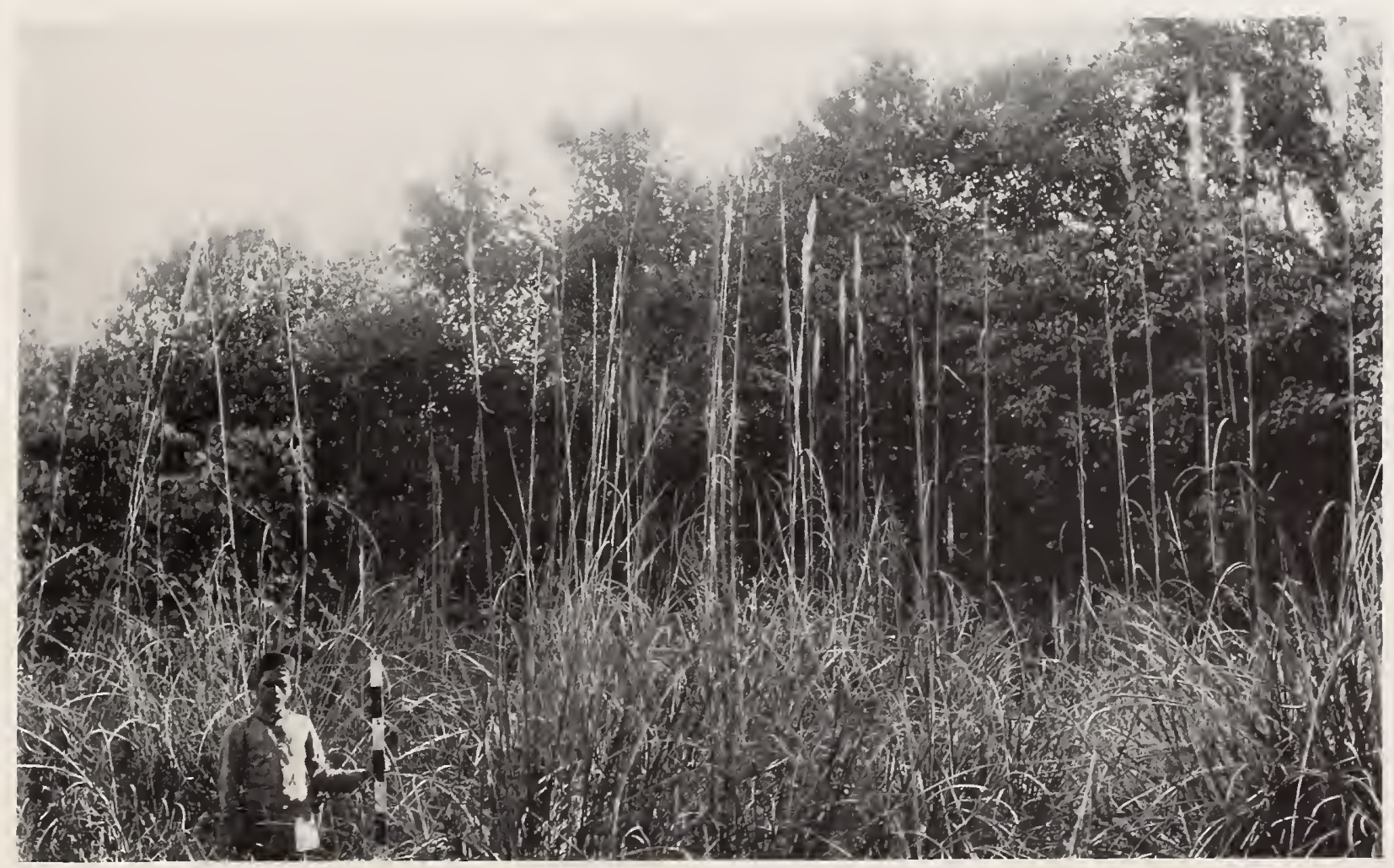

Fig. 2. 




\section{Explanation of Figures.}

Plate XI.

Saccharum Narenga the dominant grass in a shady blank in Sal Forest near Jhajra. Photograph taken 18th October 1909. 


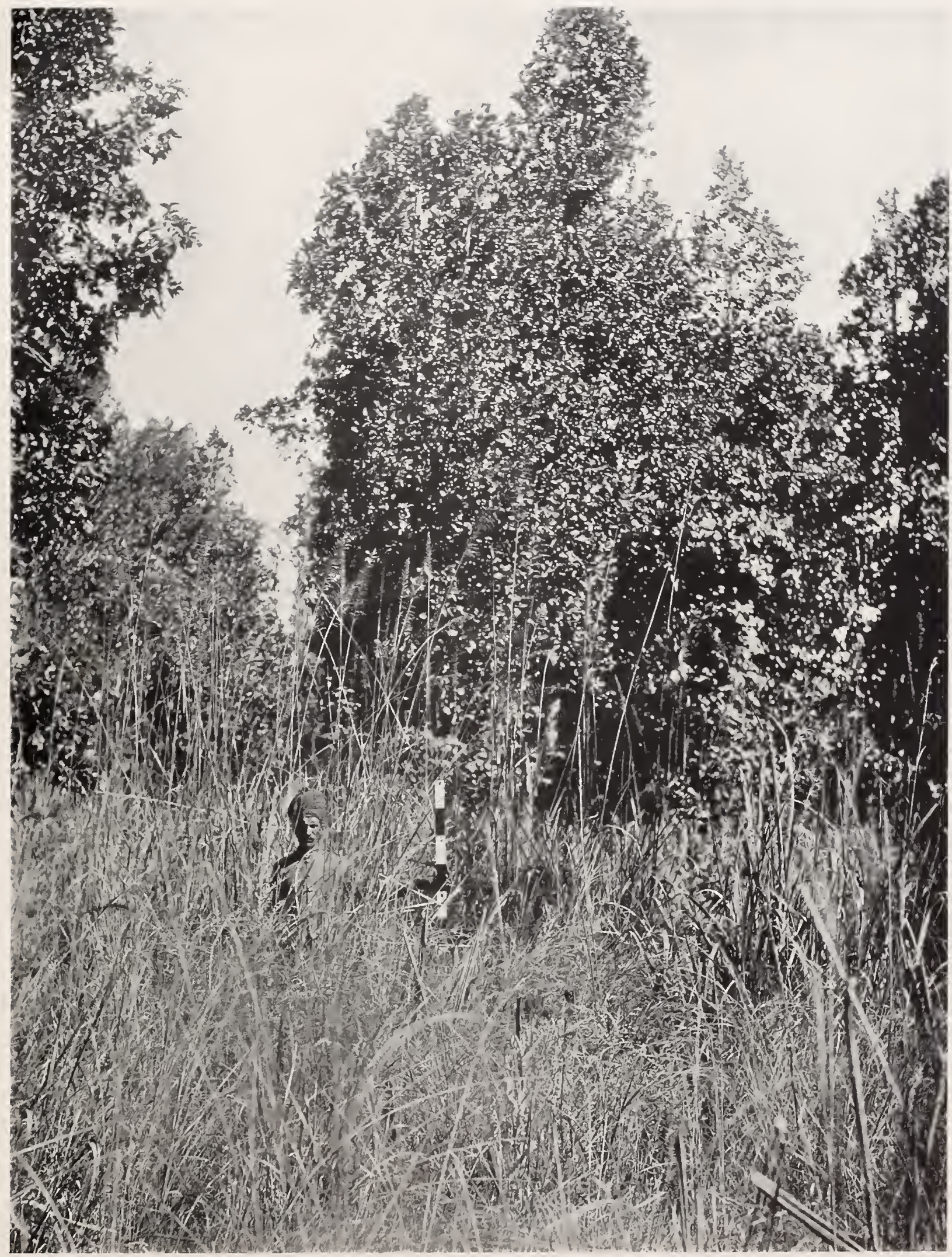






\section{Explanation of Figures.}

Plate XII.

Saccharum Narenga the dominant grass in a shady blank in Sal Forest near Jhajra. Photograph taken 18th October 1909. 


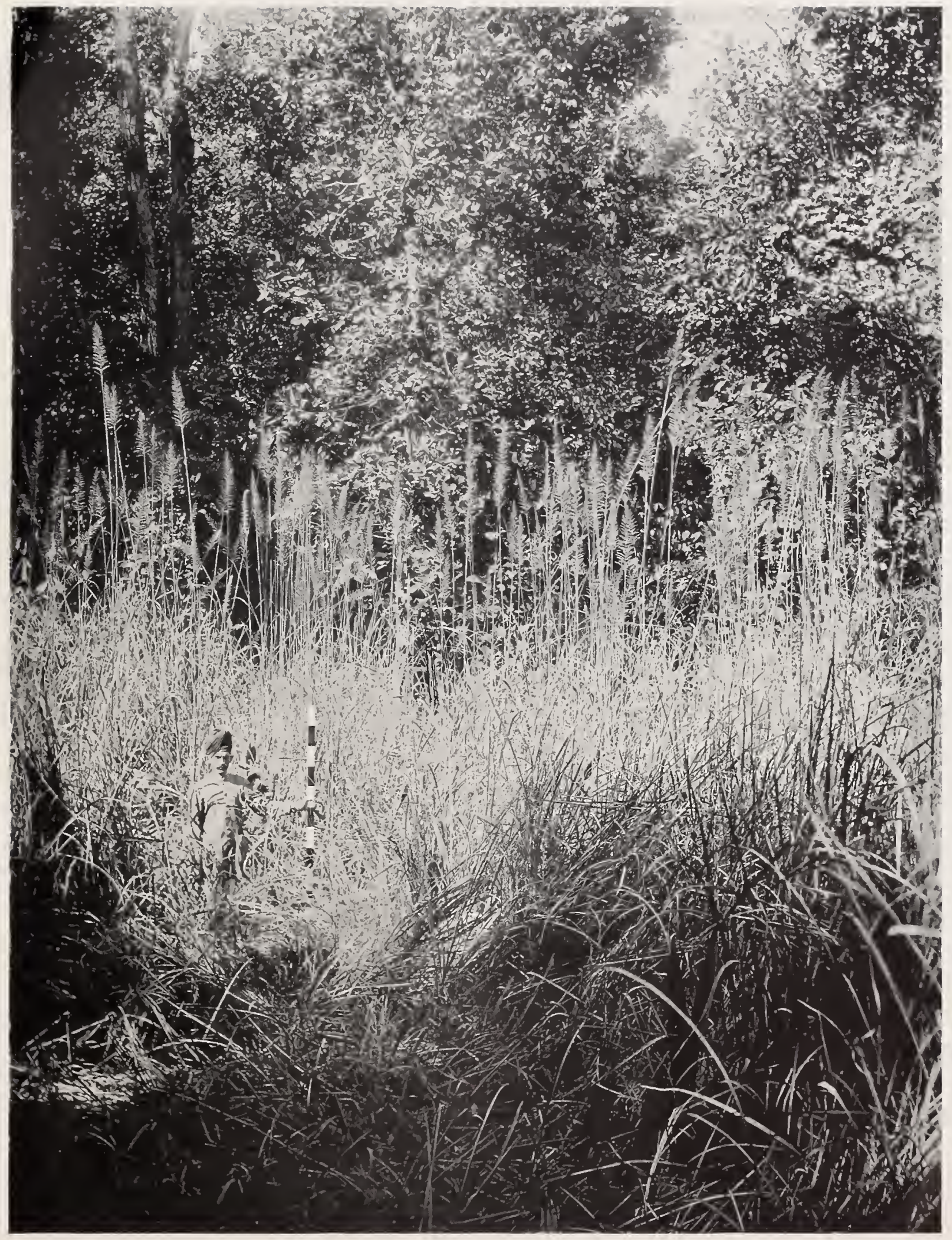





\section{Explanation of Figures.}

\section{Plate XIII.}

Figs. 1 and 2 flowering panicles, Figs. 3 and 4 fruiting panicles, of the loam-form of Saccharum spontaneum, as usually found in wet pasture lands. Note the spreading habit of growth. The grass here is cut annually at the close of the rains.

Photograph taken at Dehra Dun, September 1909. 


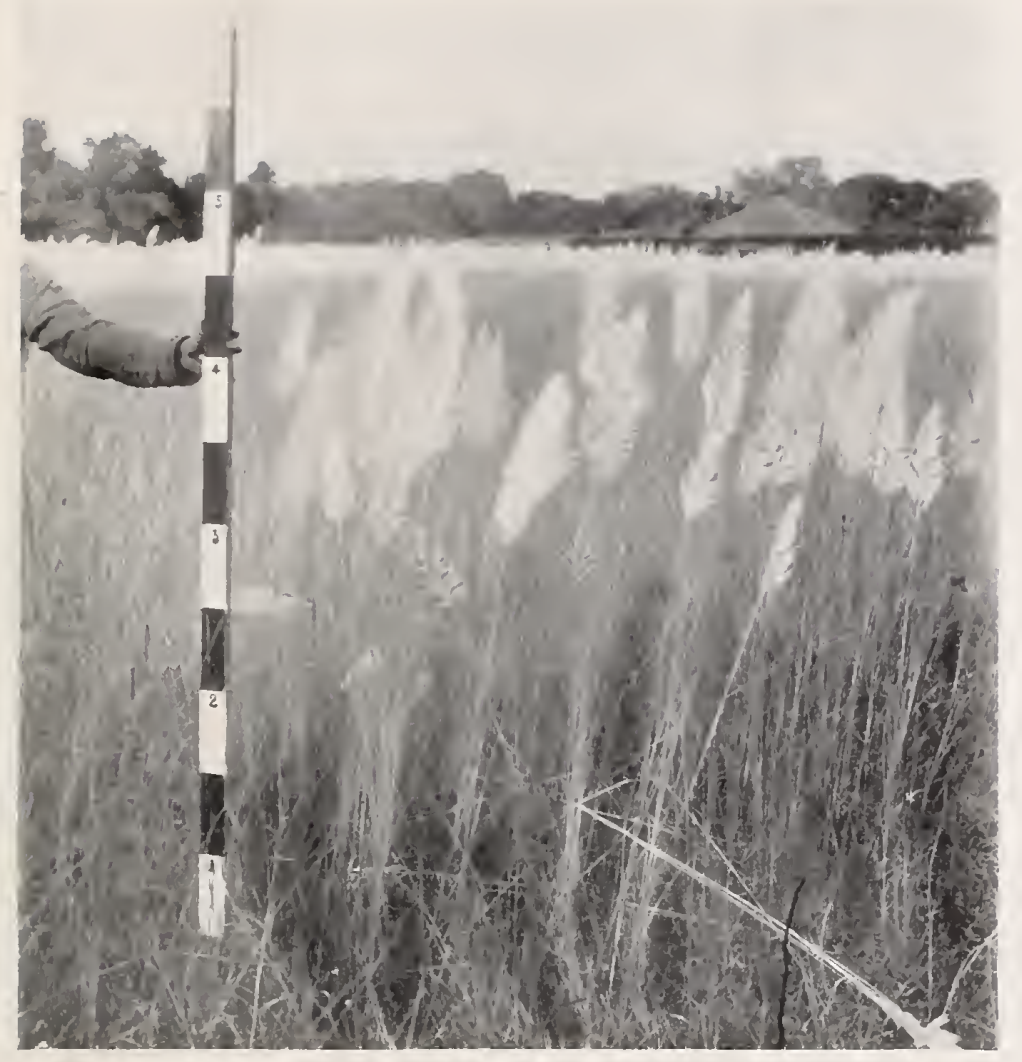

Fig. 2.

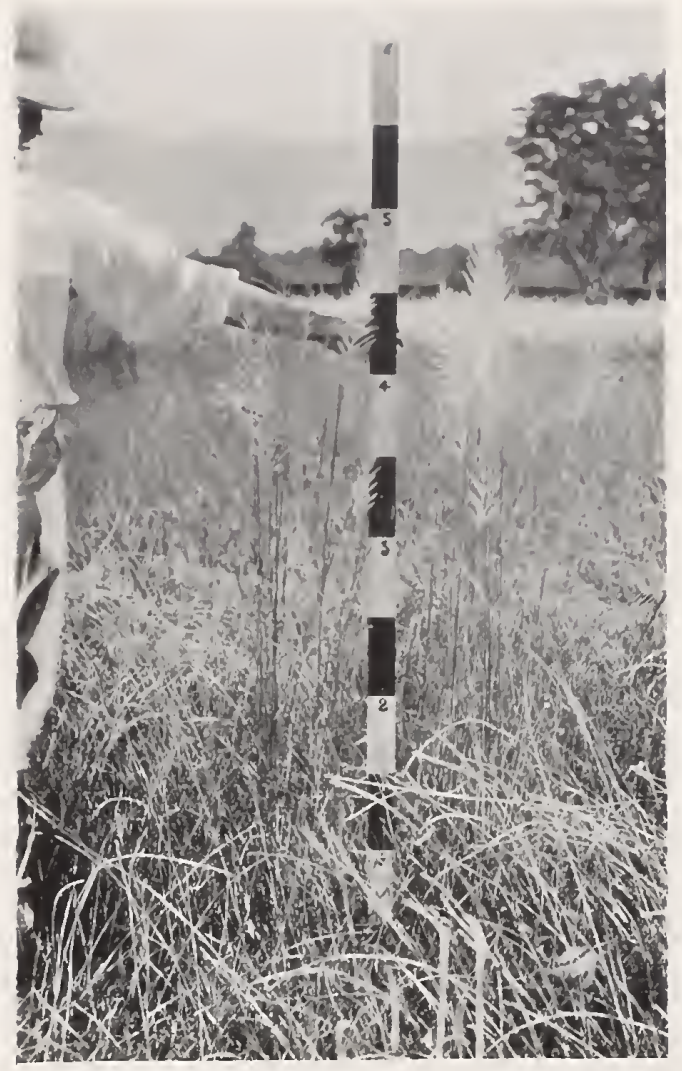

Fig. 1.

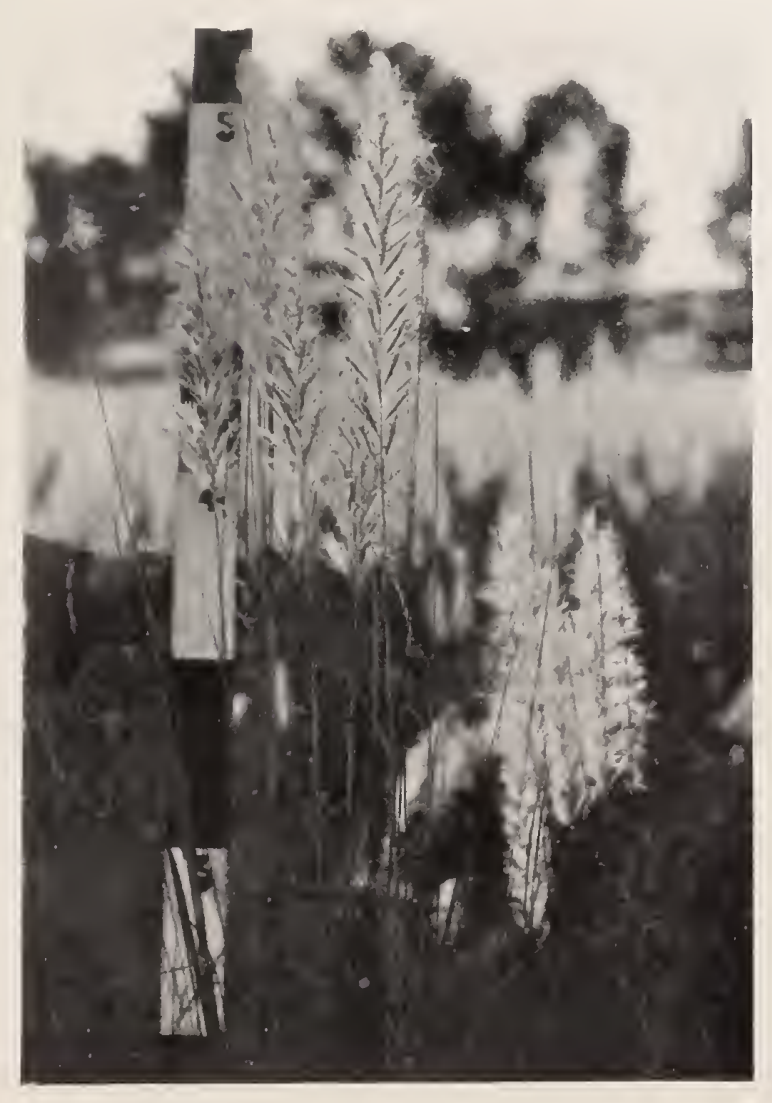

Fig. 3.

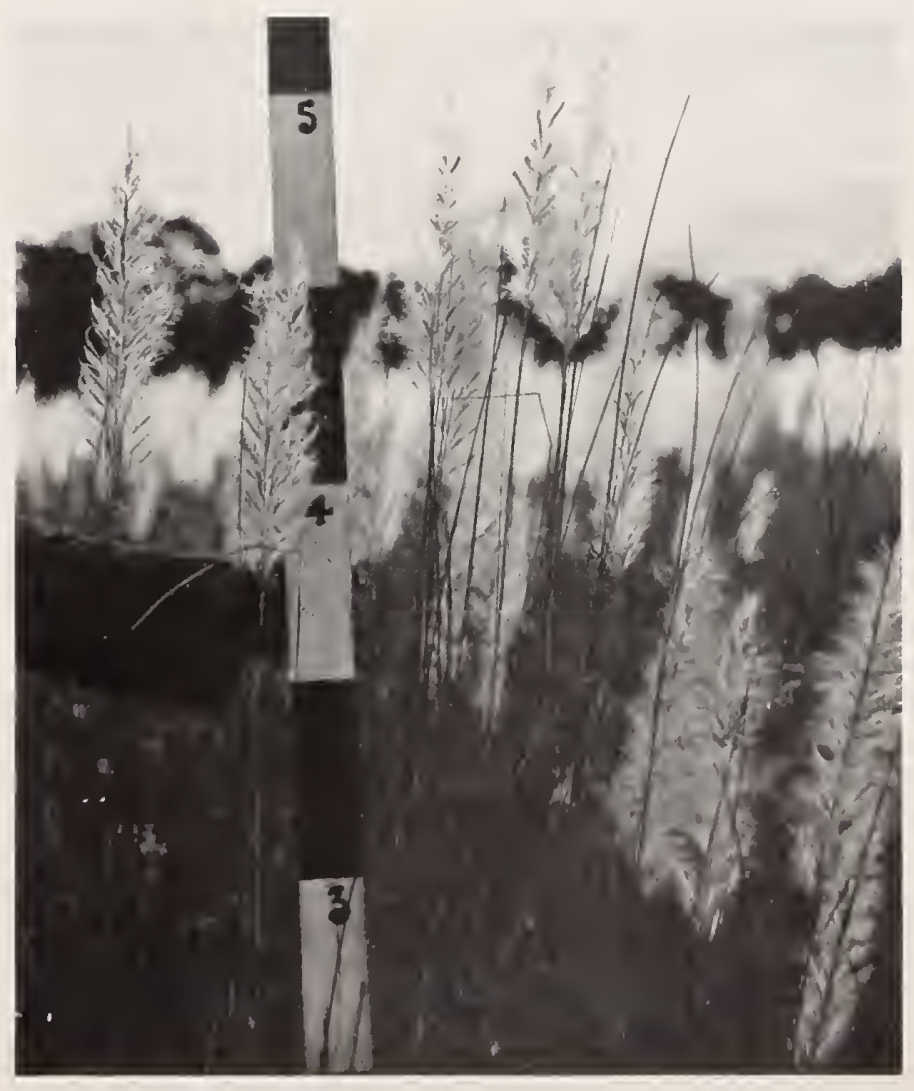

Fig. 4. 


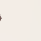





\section{Explanation of Figures.}

\section{Plate XIV.}

Fig. 1. The tufted form of Saccharum spontaneum as usually found on sand.

The four plants shown were collected in May 1909 and planted at once in the Dehra Dun Experimental Garden, where they were photographed in December 1909.

The two thin clumps on the left had been burnt while the two on the right had not been burnt.

$\therefore$ 2. A plant of the tufted sand-form of Saccharum spontaneum collected in January 1909 which had been severely damaged and almost killed by a fire in May 1908.

. 3. Another plant of the tufted sand-form of Saccharum spontaneum. 


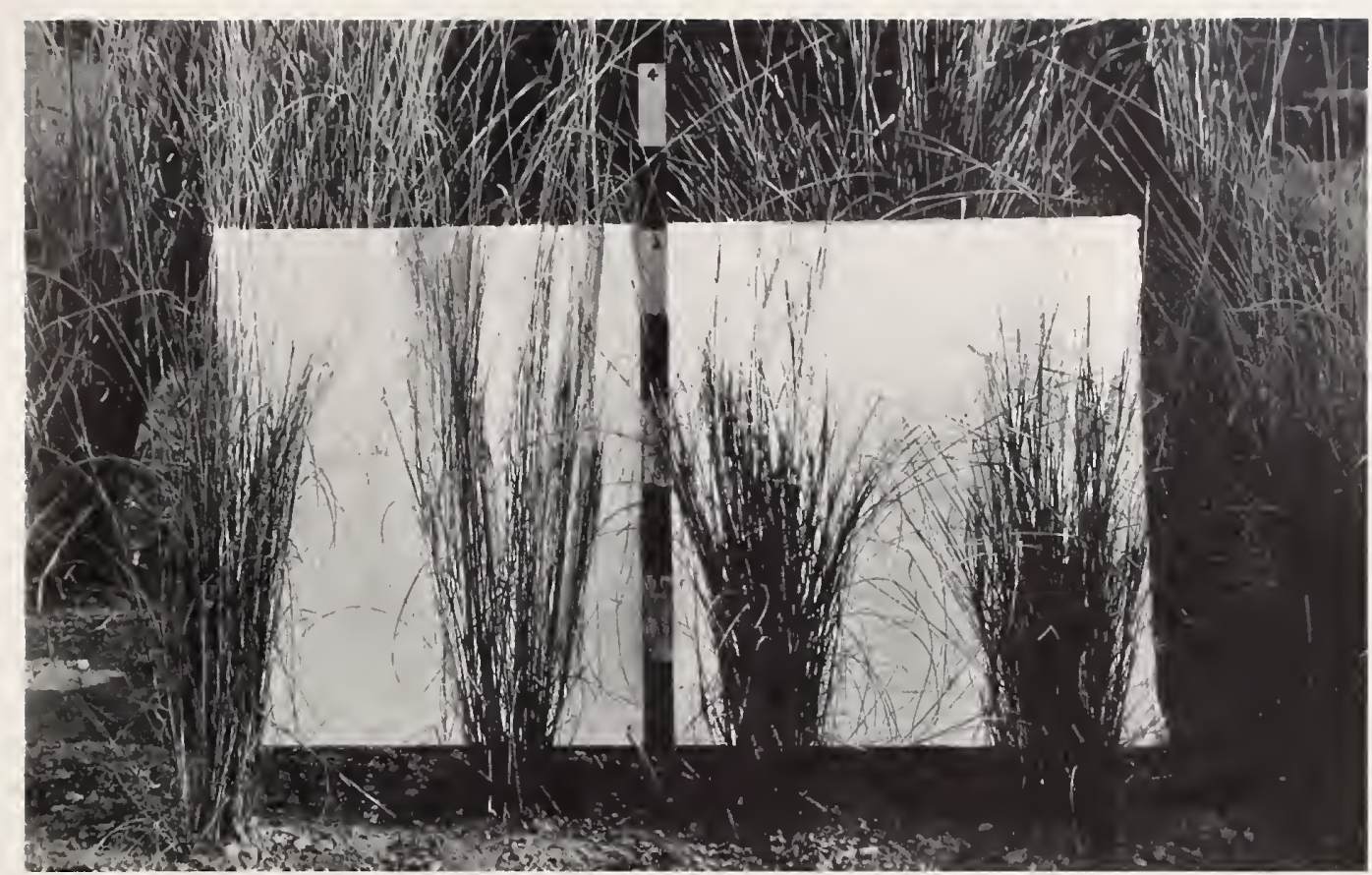

Fig. 1.

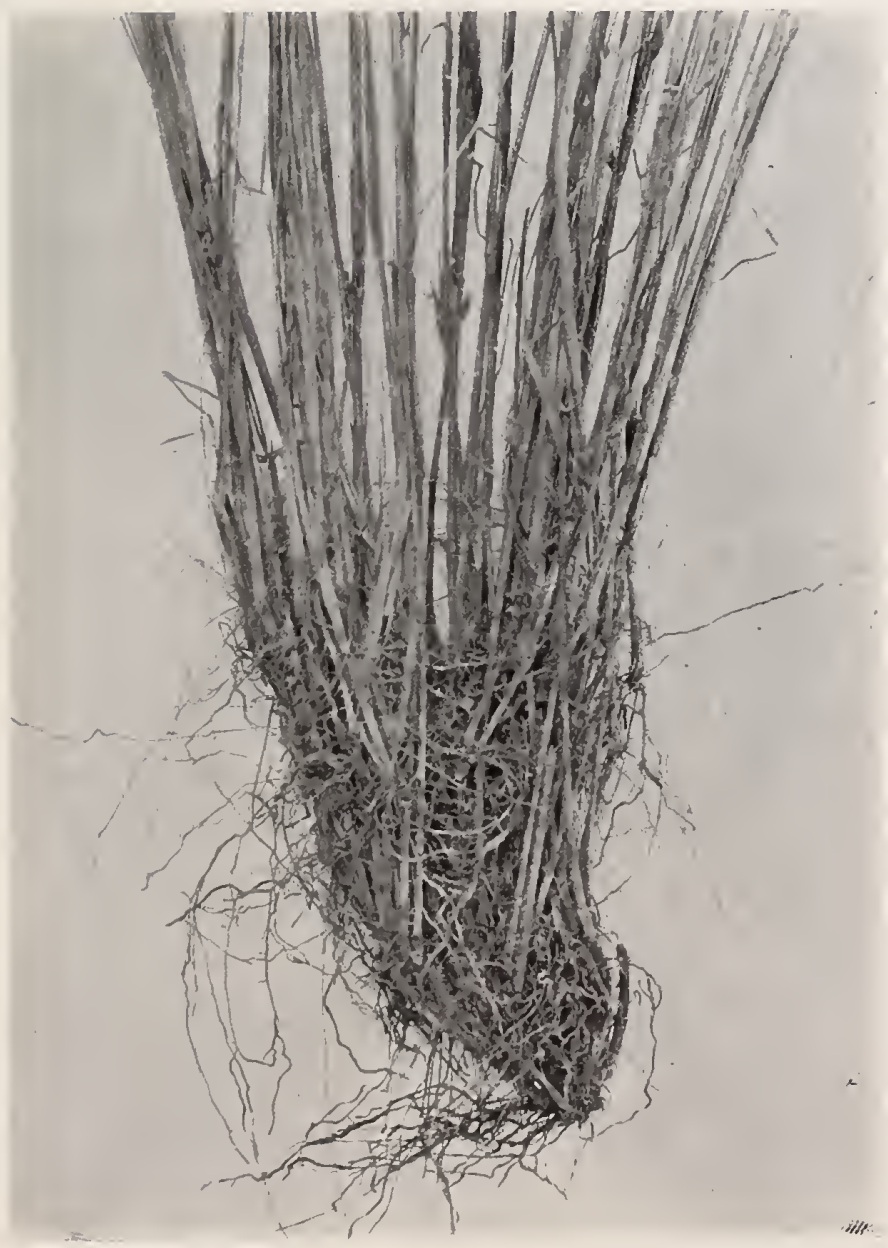

Fig. 3.

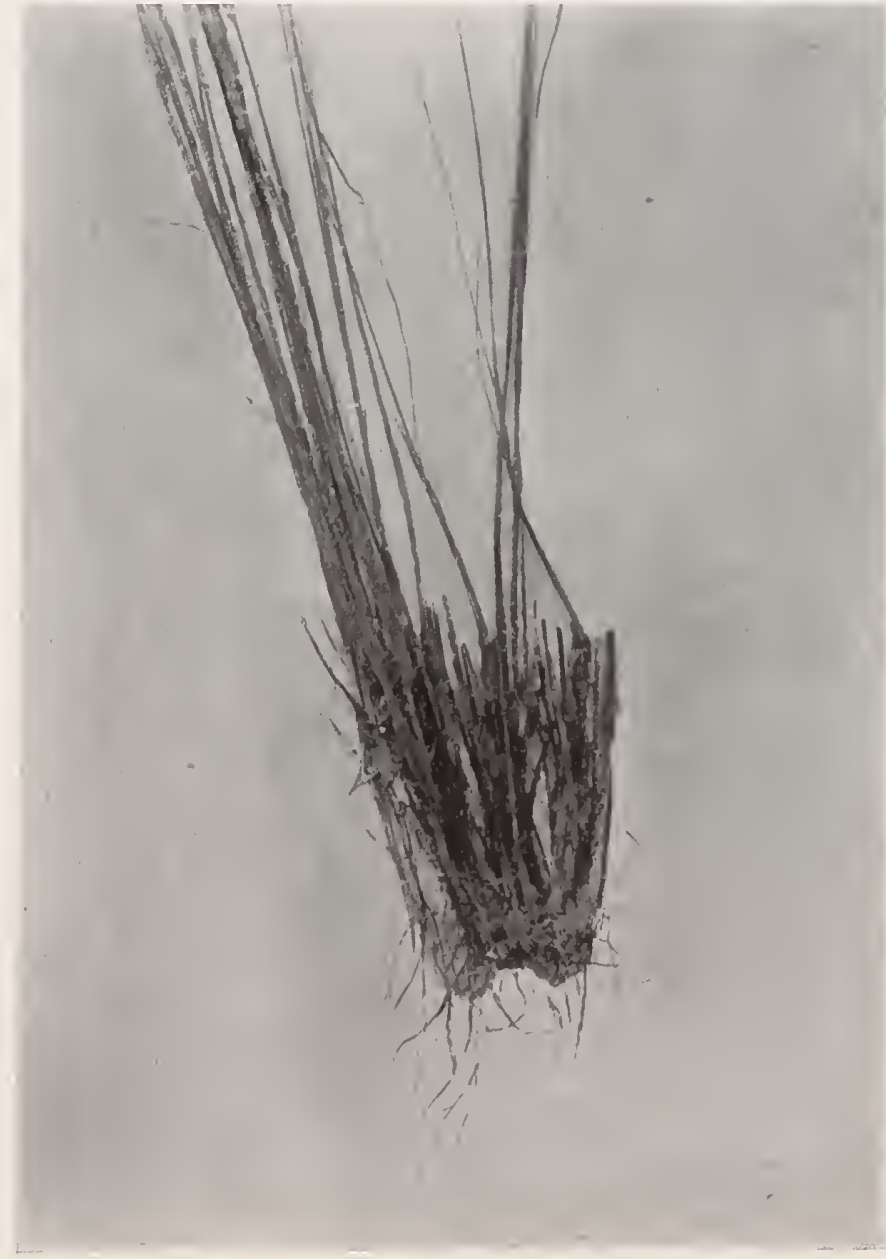

Fig. 2. 



\section{Explanation of Figures.}

Plate XV.

Figs. 1 and 2, plants of the ordinary spreading loam-form of Saccharum spontaneum, as usually found in wet pastures.

Fig. 3. The Asan River near Jhajra, with the Siwalik Hills in the background. The water-logged soil in, and close to, the river bed is occupied by Saccharum spontaneum var. nepalense. The plants show inferior dimensions, as the area is heavily grazed and the grass here is also cut for thatching purposes. Photograph taken October 1909. 


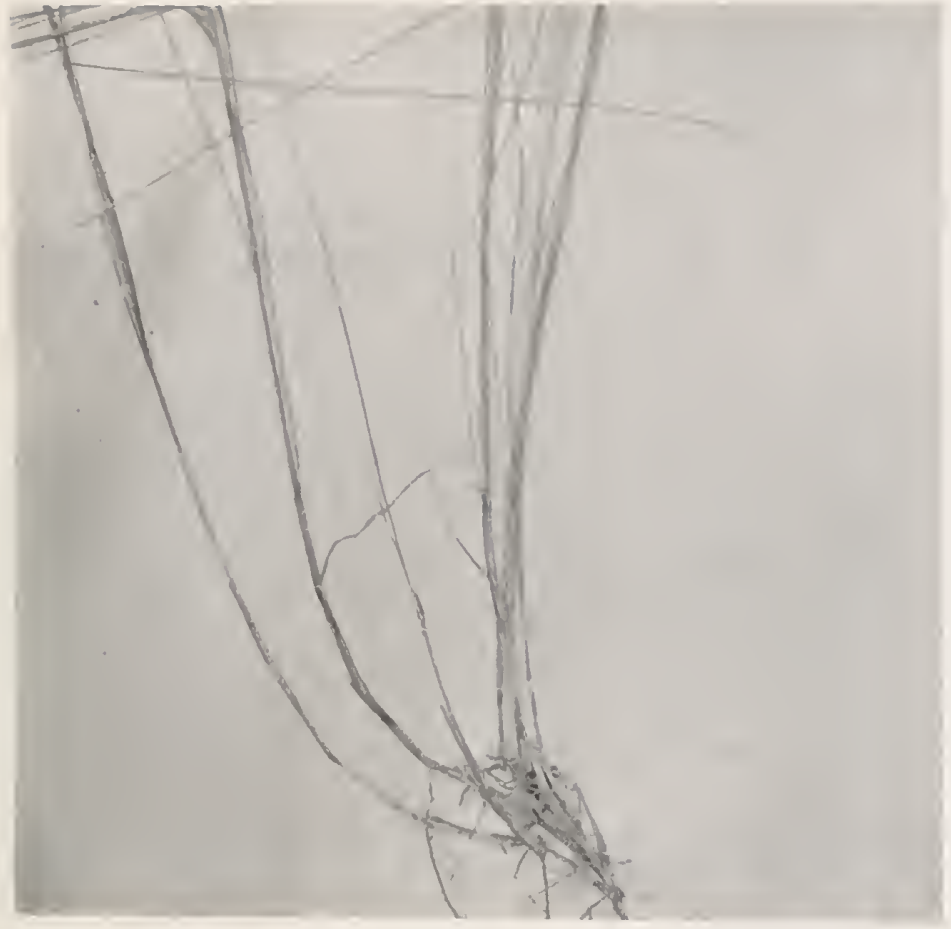

Fig. 1.

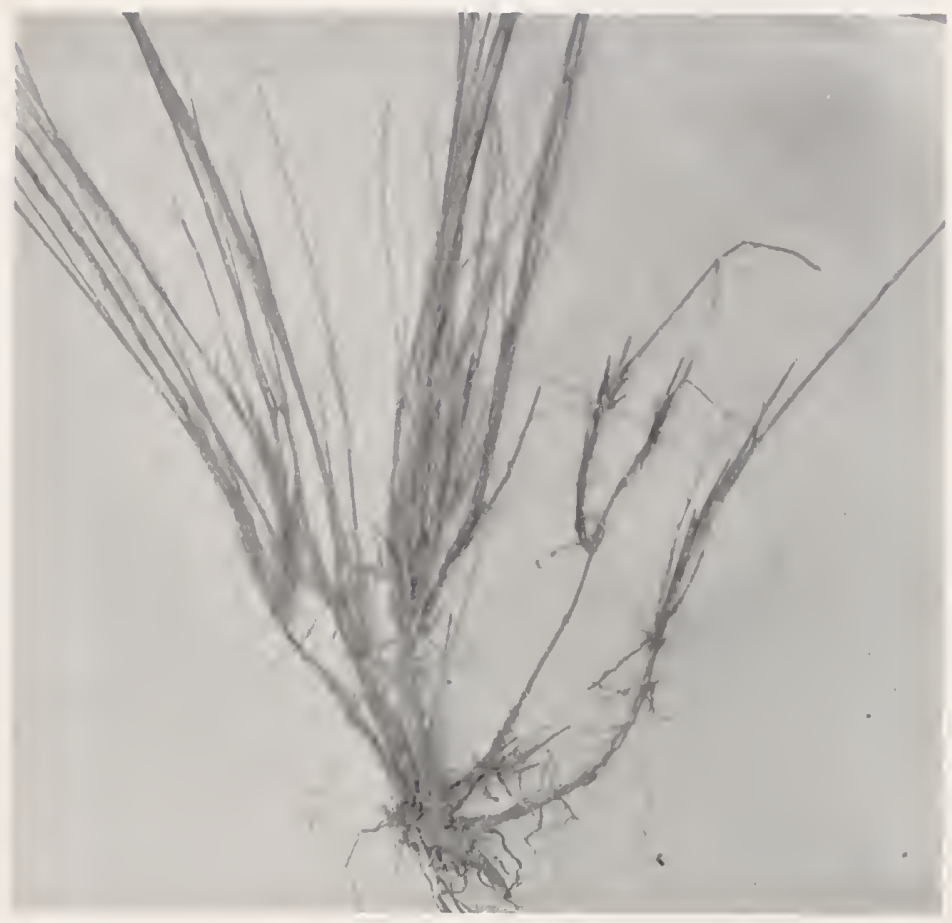

Fig. 2.

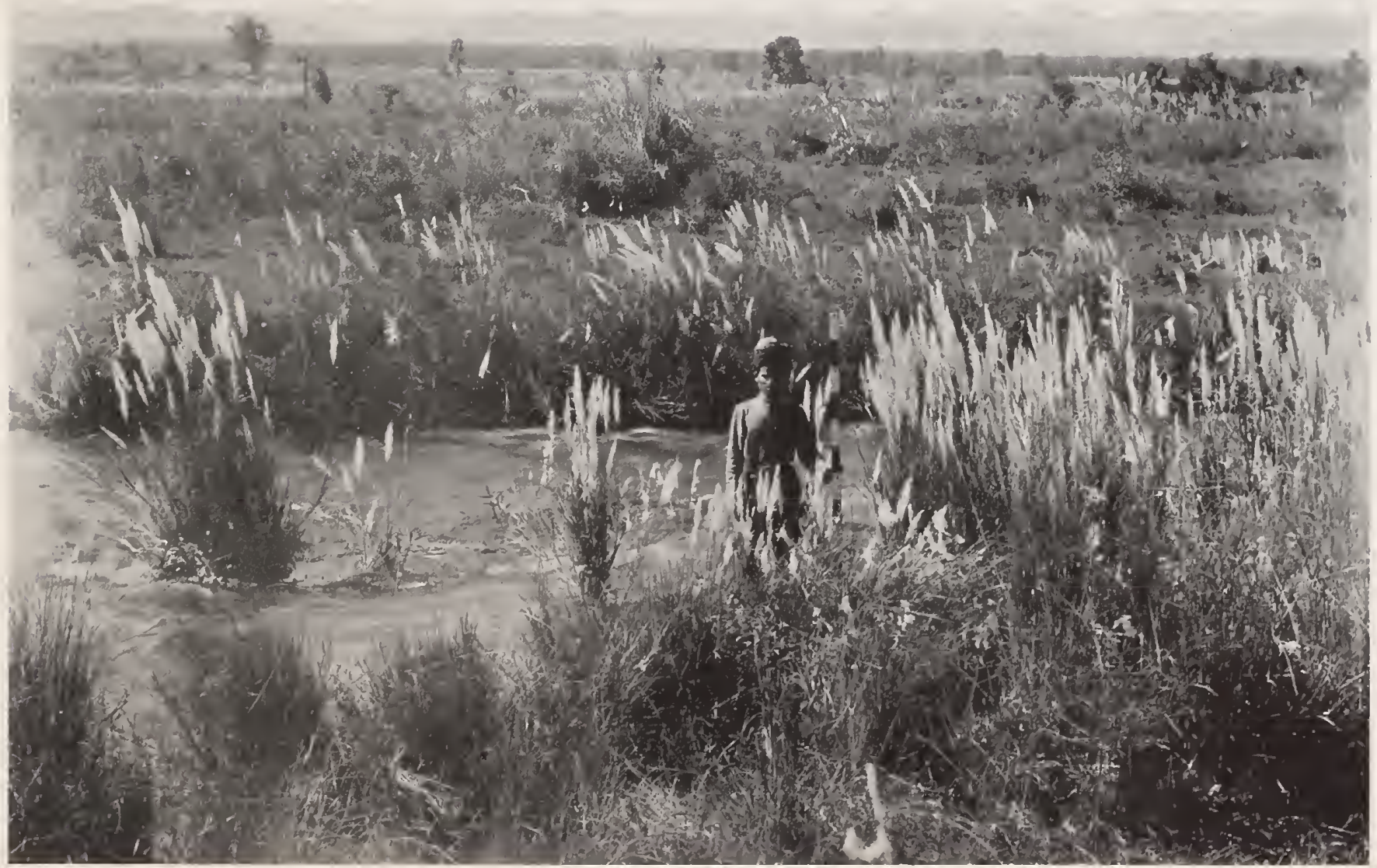

Fig. 3. 



\section{Explanation of Figures.}

\section{Plate XVI.}

Fig. 1. Flowering panicle of Saccharum spontaneum $\times \frac{3}{4}$.

"2. Culm and leaf of same species $\times \frac{3}{4}$.

"3. Ligule of same $\times \frac{3}{4}$.

"4. Portion of culm of same with axillary shoot, the culm is solid above and fistular below, (a) the culm node, (b) the leaf insertion $\times \frac{\mathbf{3}}{4}$.

„5. Culms of same with an erect habit of growth originating from the nodes of an older culm. Note the short internodes C, C, at the base of the culms. (a) the culm node, (b) the leaf insertion $\times \frac{3}{4}$.

"6. Base of culm of same showing the spreading habit of growth; CC the short internodes at base of culm $\times \frac{3}{4}$.

"7. Flowering spikelet of same $\times 6$. 


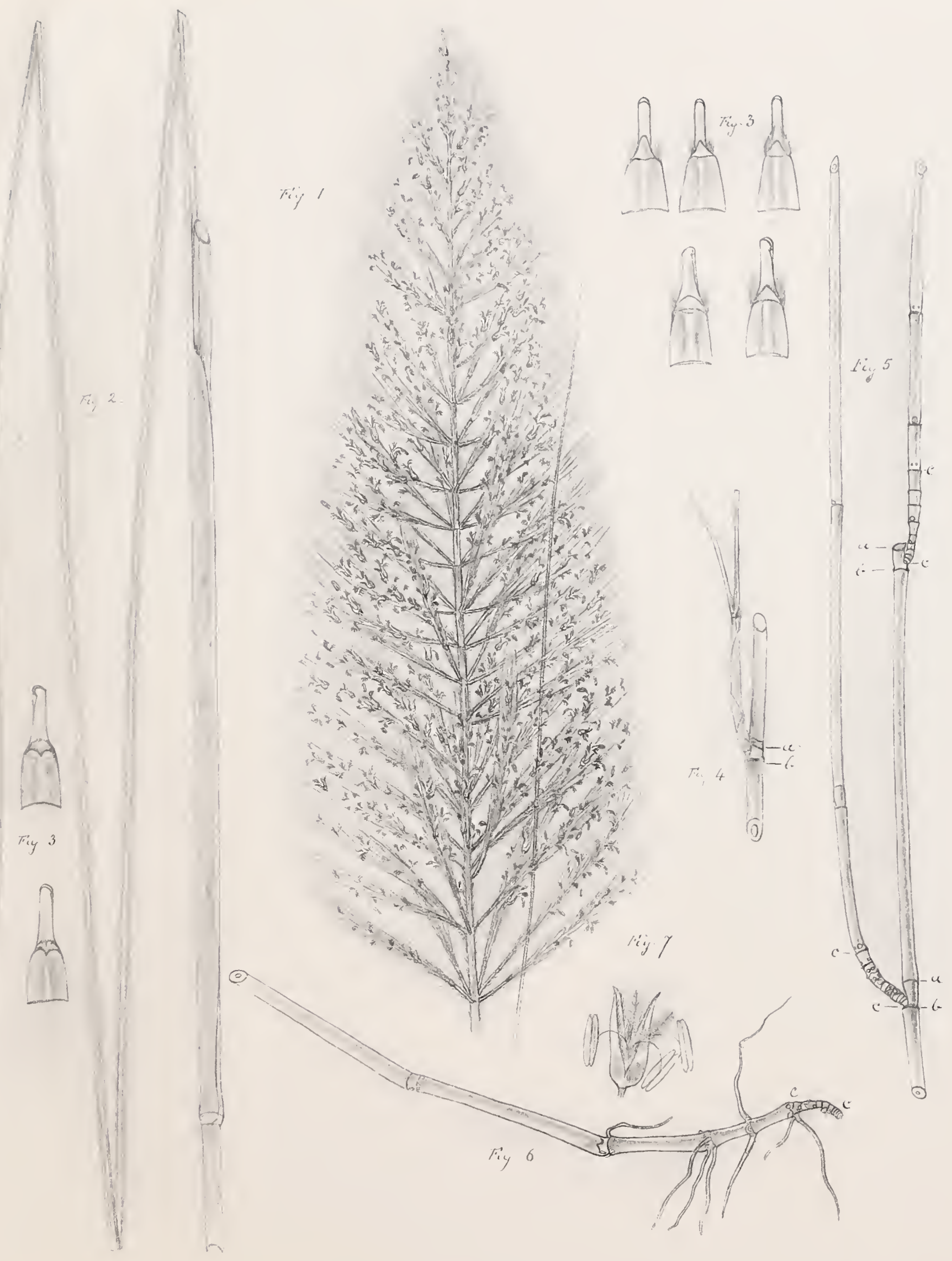






\section{Explanation of Figures.}

\section{Plate XVII.}

Fig. 1. Fruiting panicle of Saccharum spontaneum $\times \frac{3}{4}$.

, 2. Leaf of same $\times \frac{3}{4}$.

"3. Pair of flowering spikelets of same with joint of axis; note the erect callus hairs, $\times 3$.

"4. Fruiting sessile spikelet of same with joint of axis and pedicel of pedicelled spikelet which has fallen off. Note the wide-spreading callus hairs $\times 3$.

. 5. Flowering spikelet of same $\times 6$.

"6. Glume I of spikelet

"7. , II ",

"8. , III ,

"9. " IV "

"10. Pale

„11. Lodicules

,12. Stamens

13. Ovary

,14. Ovary stamens and lodicules 


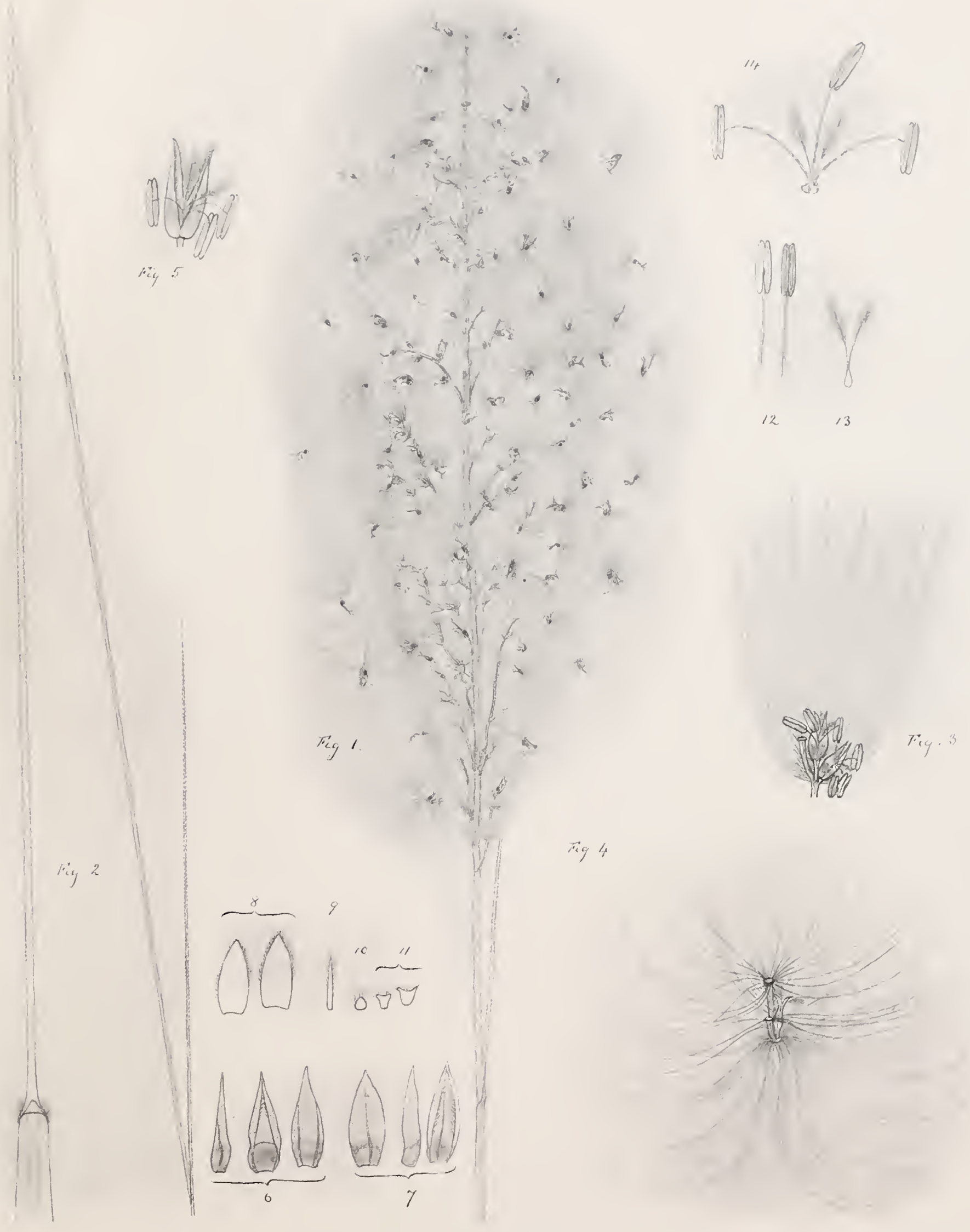






\section{Explanation of Figures.}

\section{Plate XVIII.}

Fig. 1. Fruiting panicle of Saccharum spontaneum var. nepalense $\times \frac{3}{4}$.

, 2. Leaf of same $\times \frac{3}{4}$.

, 3. Pedicelled spikelet of same $\times 2 \frac{1}{4}$.

"4. Sessile spikelet of same with pedicel, from which the pedicelled spikelet has fallen off, and joint of axis $\times 2 \frac{1}{4}$.

", 5. Basal portion of culm of same with axillary shoot. Note that culm is fistular $\times \frac{3}{4}$.

"6. Upper portion of culm of same. Note that culm is solid $\times \frac{3}{4}$.

Figs. 7 and 8. Culm of sand-form of Saccharum spontaneum showing the effect of cutting off the leaves on the length of the internodes. The culm was cut over at $\mathrm{X}$ and thus deprived of all its green leaves which were visible on the date of cutting. When the culm was drawn however the continued growth of the apical bud of the culm and of the leaf rudiments which had been uninjured by the cutting had produced a new terminal tuft of green leaves. This cutting resulted in the removal of the entire lamina and more or less of the sheath of 3 leaves numbered 1, 2 and 3 . In figure 8 the sheaths of these leaves have been removed to show their insertions on the culm which are also numbered 1, 2 and 3. Internode (a) had practically completed its growth on the date of cutting and is of normal length. It will be seen however that internode (b) has not increased in length since the date of cutting, as is indicated by the cut apices of the leaf sheaths 1, 2 and 3 having remained at the same level X. Compare the length of the abnormally short internode (b) with that of the normal internode (a). $\mathrm{C}$ is a leaf of which only the apical portion of the lamina was destroyed by the cutting. 

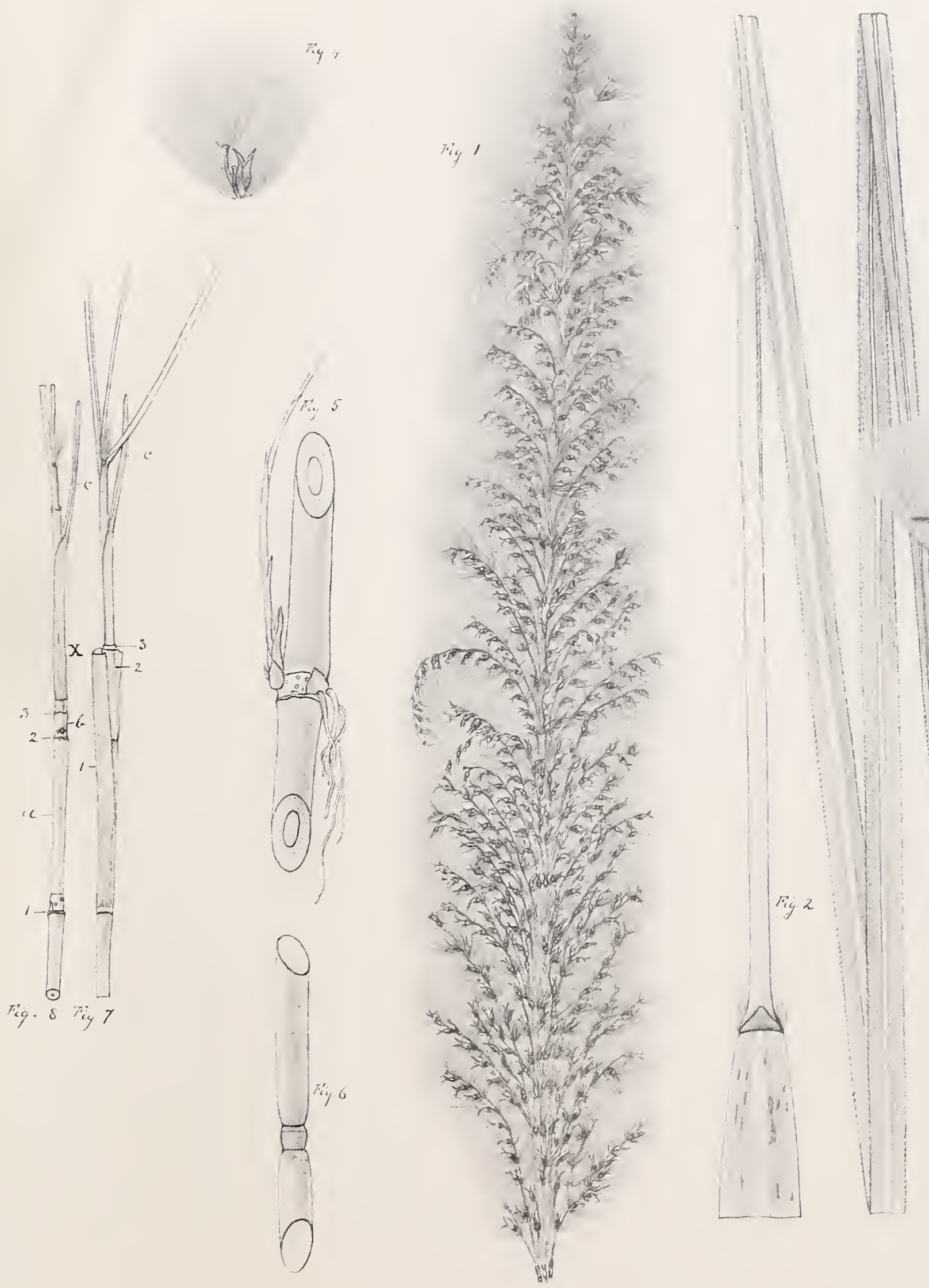



\section{Fxplanation of Figures.}

\section{Plate XIX.}

Flowering plant of Saccharum Munja.

Photograph taken on the banks of the Tons River near Jhajra on 21st October 1909. 


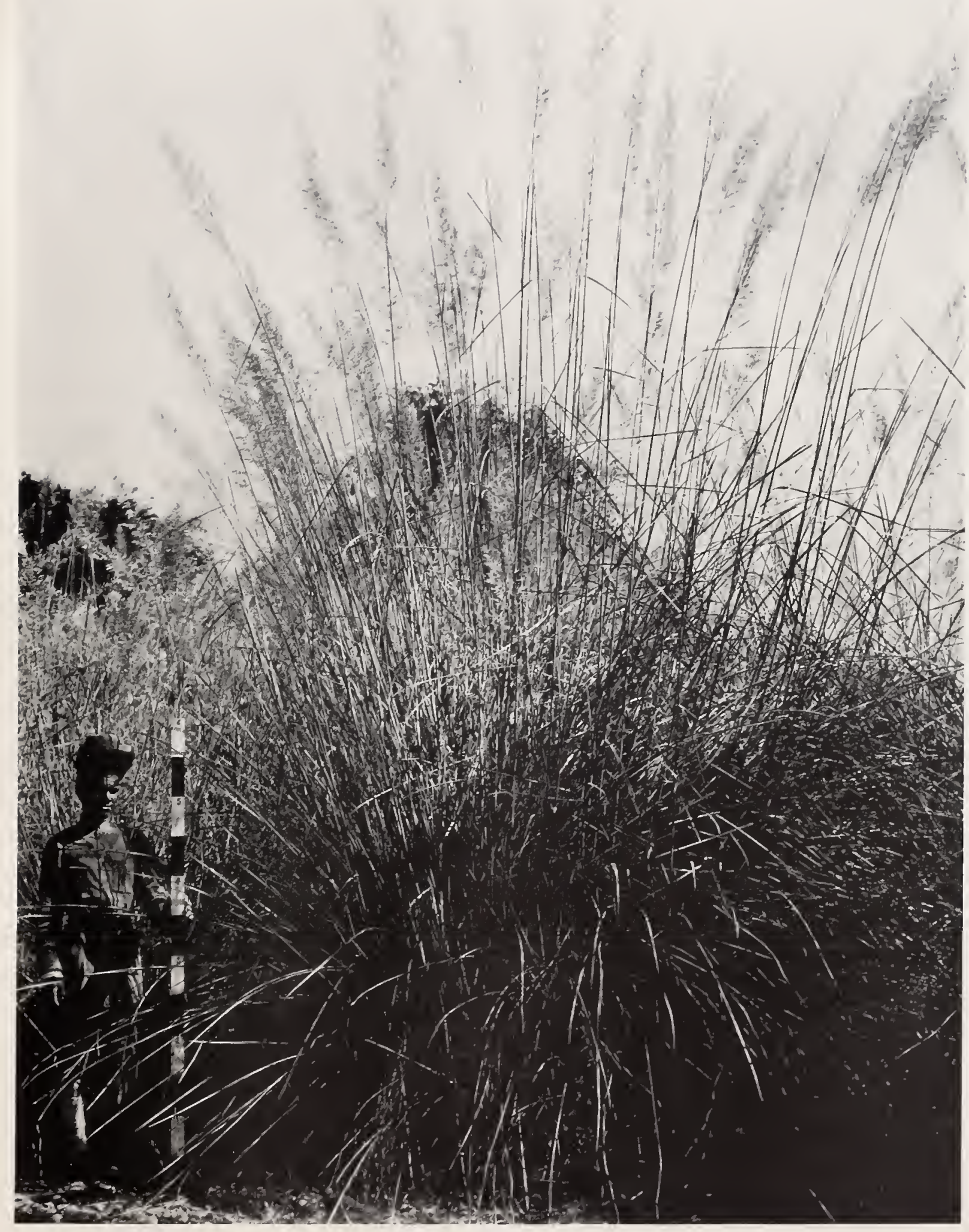






\section{Explanation of Figures.}

\section{Plate XX.}

Fig. 1. Flowering panicle of Saccharum Munja collected October 1909.

„2. Three fruiting panicles of Saccharum Munja collected November 1909.

" 3. Pair of spikelets of Saccharum Munja with joint of axis

"4. Pedicelled spikelet of same

"5. Sessile spikelet of same

1,1 , Glume 1 of sessile spikelet of same

$2,2, \quad, \quad 2 \quad, \quad$, , ,

$3,3, \quad$, $3 \quad$, , , ,

$4,4, \quad, 4 \quad$, , , , ,

P, P, Pale , , " , "

S Anthers ," , , ,

L Lodicules ", " "

I. I, Glume I of pedicelled spikelet of same II, II, , II 

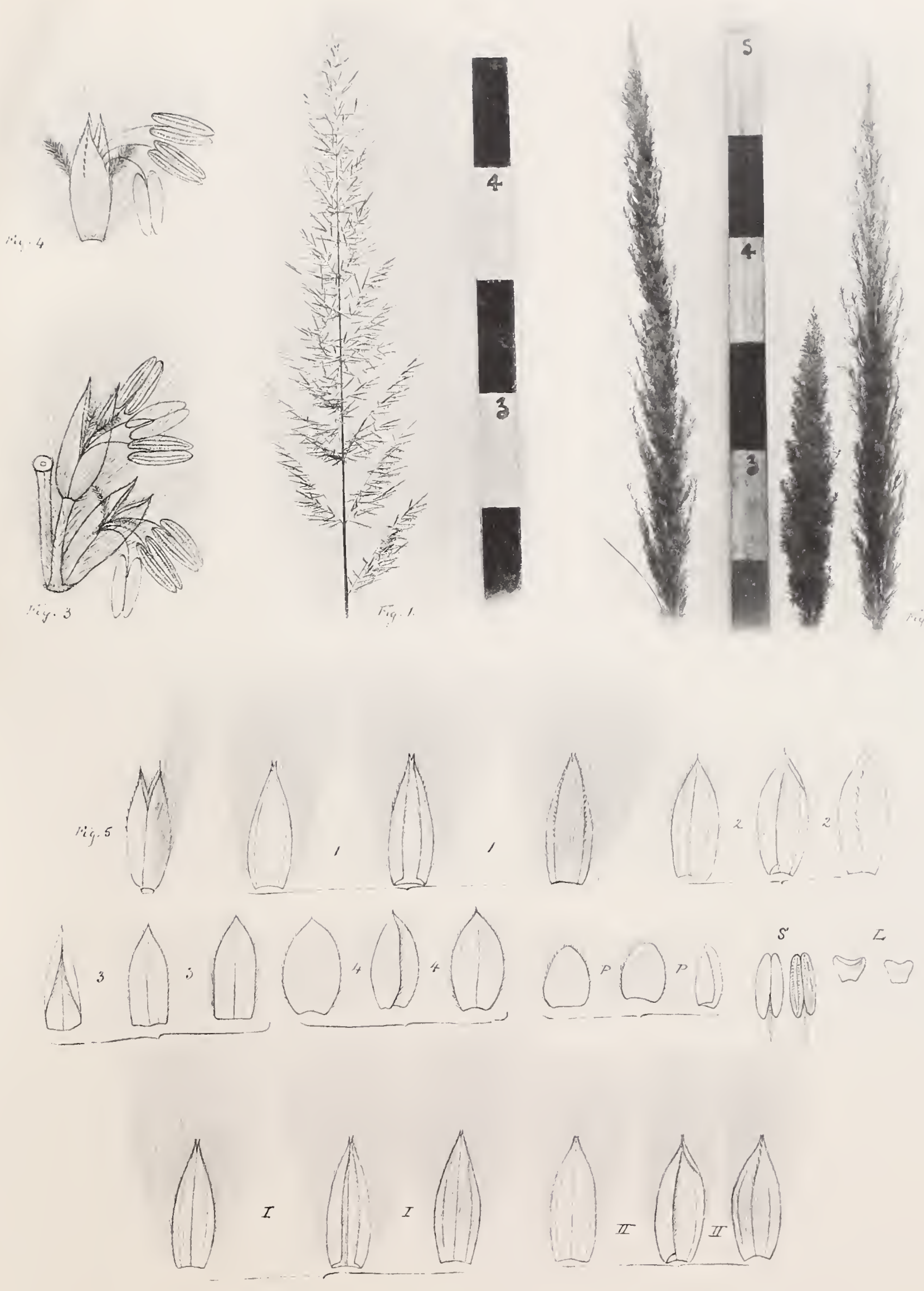



\section{Explanation of Figures.}

\section{Plate XXI.}

Fig. 1. Culm of Saccharum Munja. (a) leaf insertion, (b) culm node, (c) axillary bud $\times \frac{3}{4}$.

", 2. Leaf of same showing ligule $\times \frac{3}{4}$.

"3. Base of lamina and upper part of sheath of same, showing ligule and concavo. convex midrib $\times \frac{3}{4}$.

"4. Immature one-year culm of same with the basal leaves removed to show the short basal internodes. There are 13 short internodes of which the upper internode is still immature $\times \frac{3}{4}$.

"5. Base of mature flowering culm of same. There are 11 short basal internodes $\times \frac{3}{4}$.

, 6. Base of flowering culm of same with 13 short basal internodes and in addition to these a second series of short internodes indicating that a change has taken place in the soil level $\times \frac{3}{4}$.

"7. Portion of rhizome of same showing the aerial culms developing from the terminal bud of the rhizome. The basal leaves have been removed to show the short internodes $\times \frac{3}{4}$. 


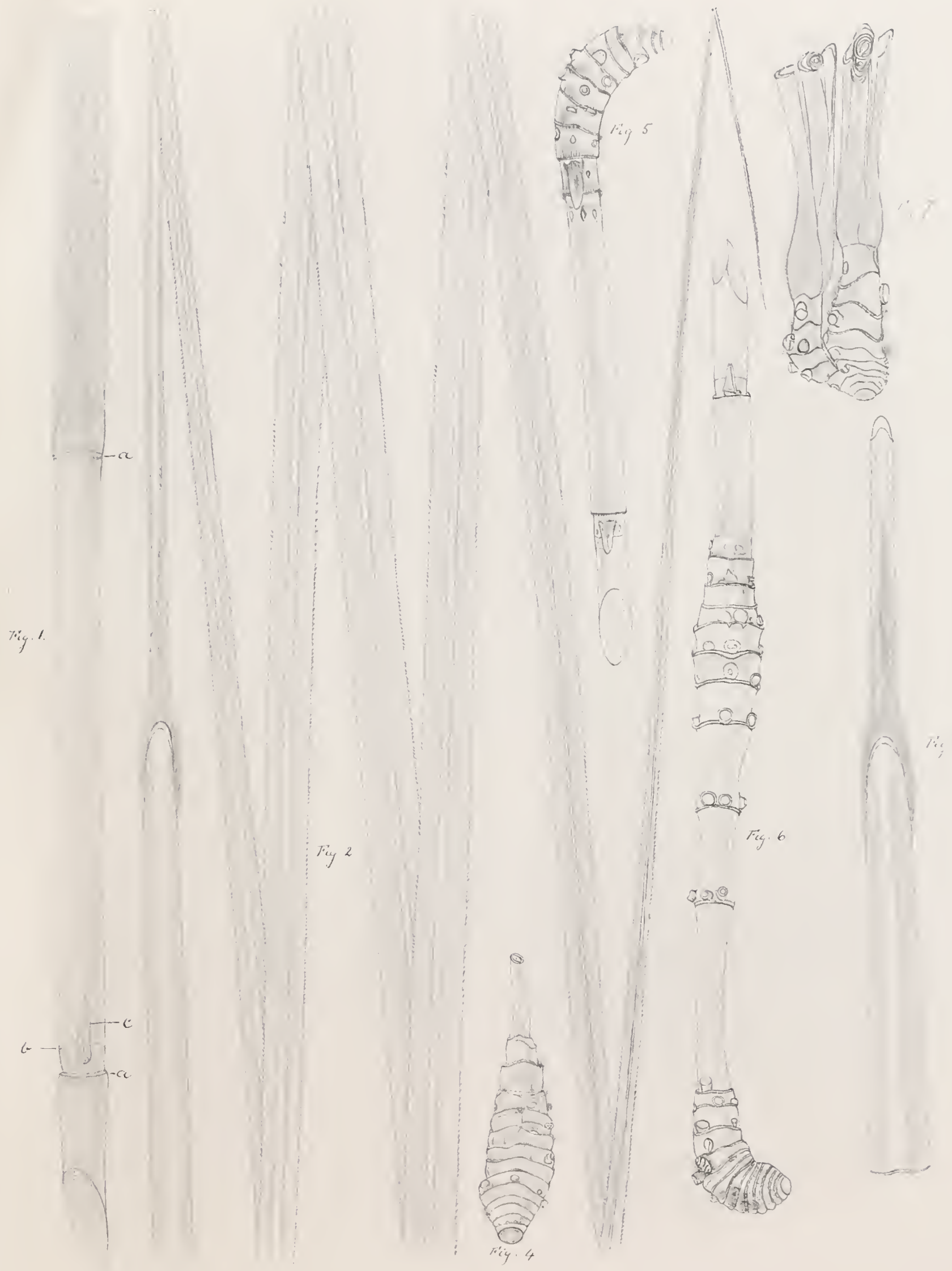






\section{Explanation of Figures.}

\section{Plate XXIT.}

Fig. 1. Saccharum arundinaceum growing in a garden at Dehra Dun. Photograph taken November 1909.

, 2. Pair of spikelets of same with joint of axis

, 3. Sessile spikelet of same with portion of joint of axis

, 4. Pedicelled spikelet of same

1, 1 , Glume 1 of sessile spikelet of same

$2,2, \quad, 2 \quad$,

$3,3, \quad, \quad 3 \quad$,

$4,4, \quad, 4$, 4

P Pale ",

L Lodicules ,

S S Stamens ,

O Ovary

I, I, Glume I of pedicelled spikelet of same

II, II,

I of pedicelled spikelet of sam , , ,

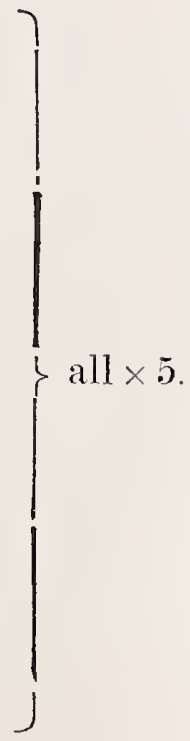



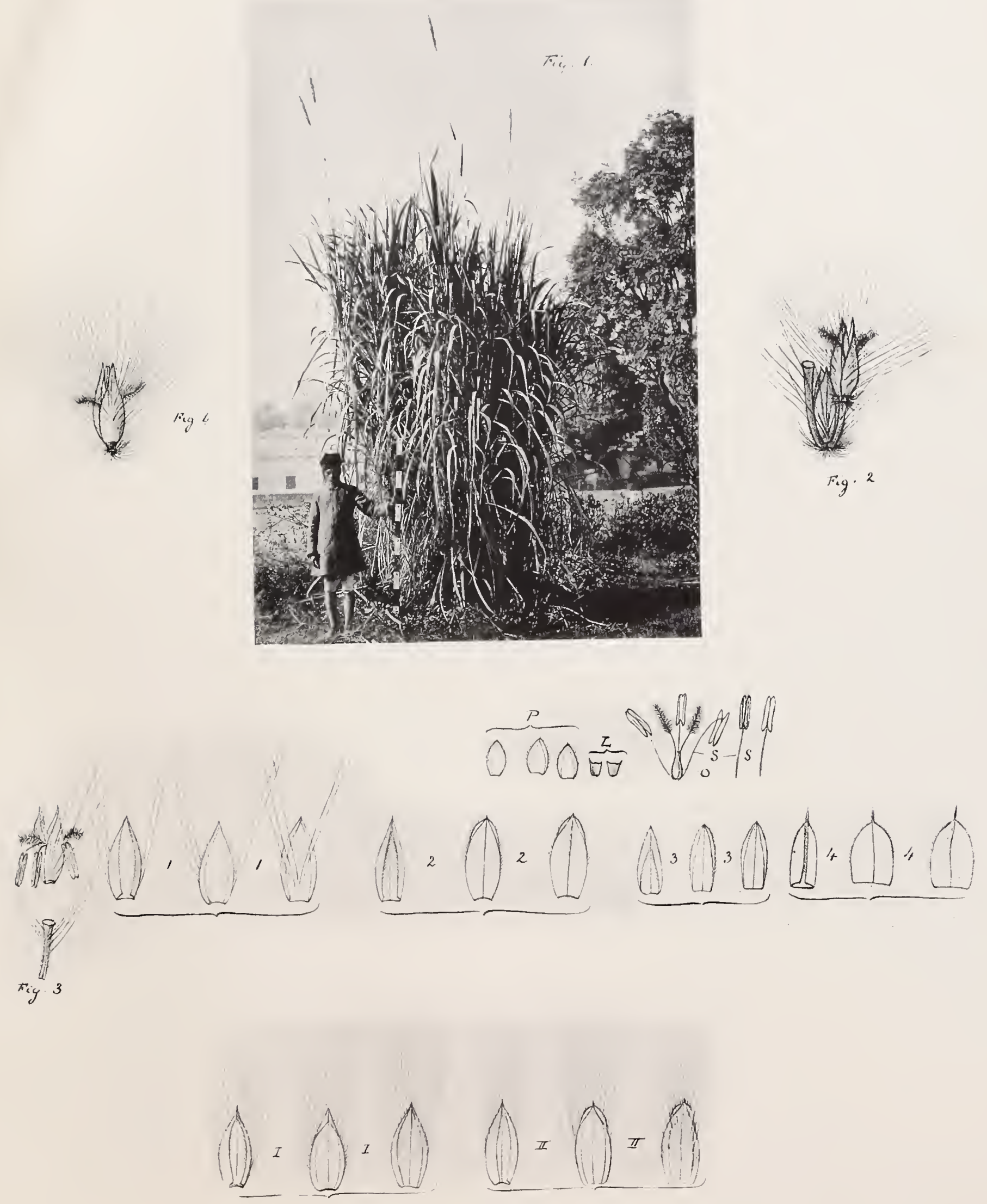

• 


\section{Explanation of Figures.}

\section{Plate XXiII.}

Fig. 1. Flowering panicle of Saccharum Narenga Wall. Collected October 1909.

„2. Four fruiting panicles of S. Narenga all collected from the same plant on 20 th November 1909. The two on left of staff and the outer one on the right are normal. The panicle next the staff on the right was caused to dry prematurely on the plant by bending the flowering culn. Note the tenacious panicle branches.

"3. Tro abnormal fruiting panicles of $S$. Narenga caused by the culms being damaged by insects and fungi. Note the tenacious panicle branches. Collected November 1909.

„ 4. A group of three plants of $S$. Narenga in Dehra Dun Experimental Garden. The fragile branches of the fruiting panicles have broken up leaving oniy the persistent, spike-like, primary rachis.

Photograph taken December 9th, 1909. 


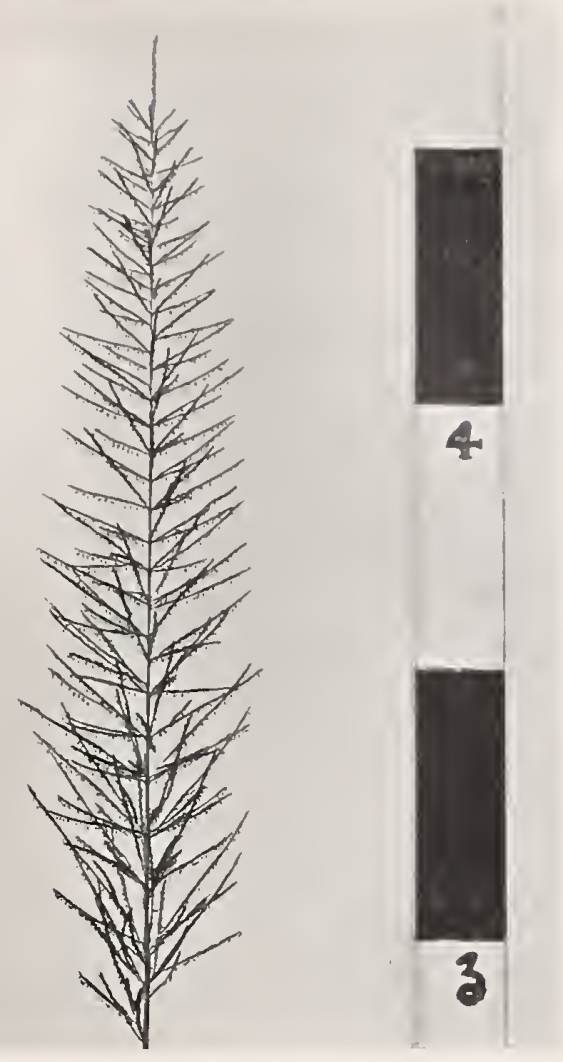

Fig. 1.

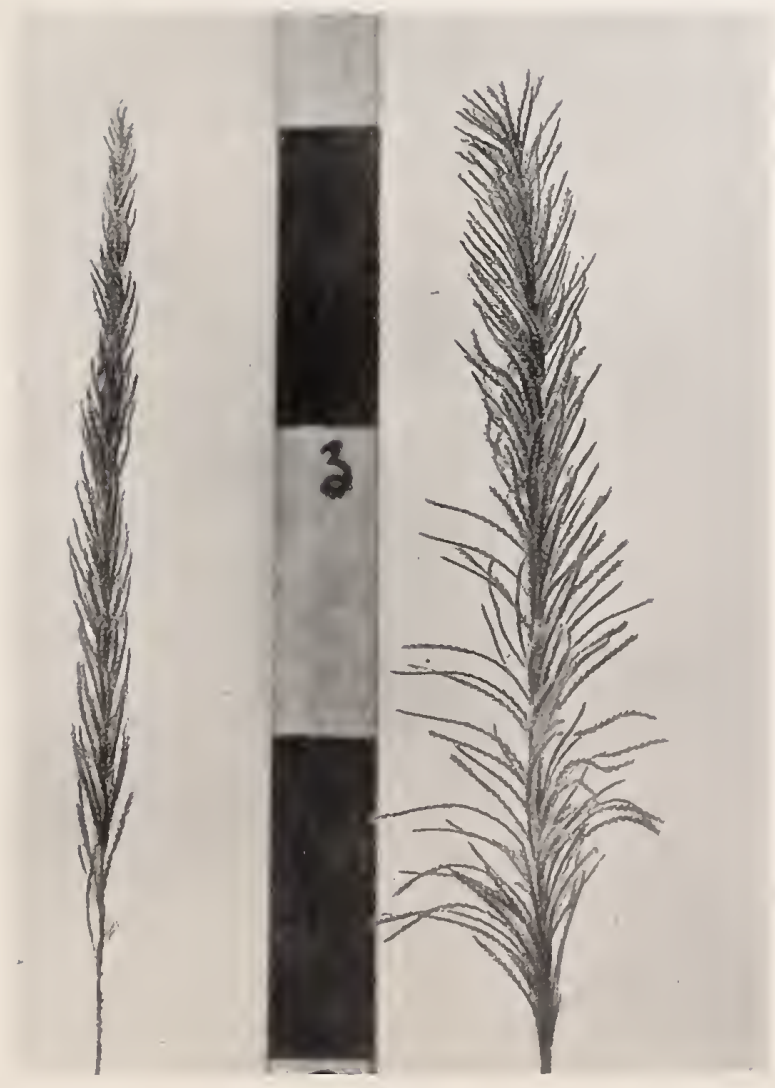

Fig. 3.
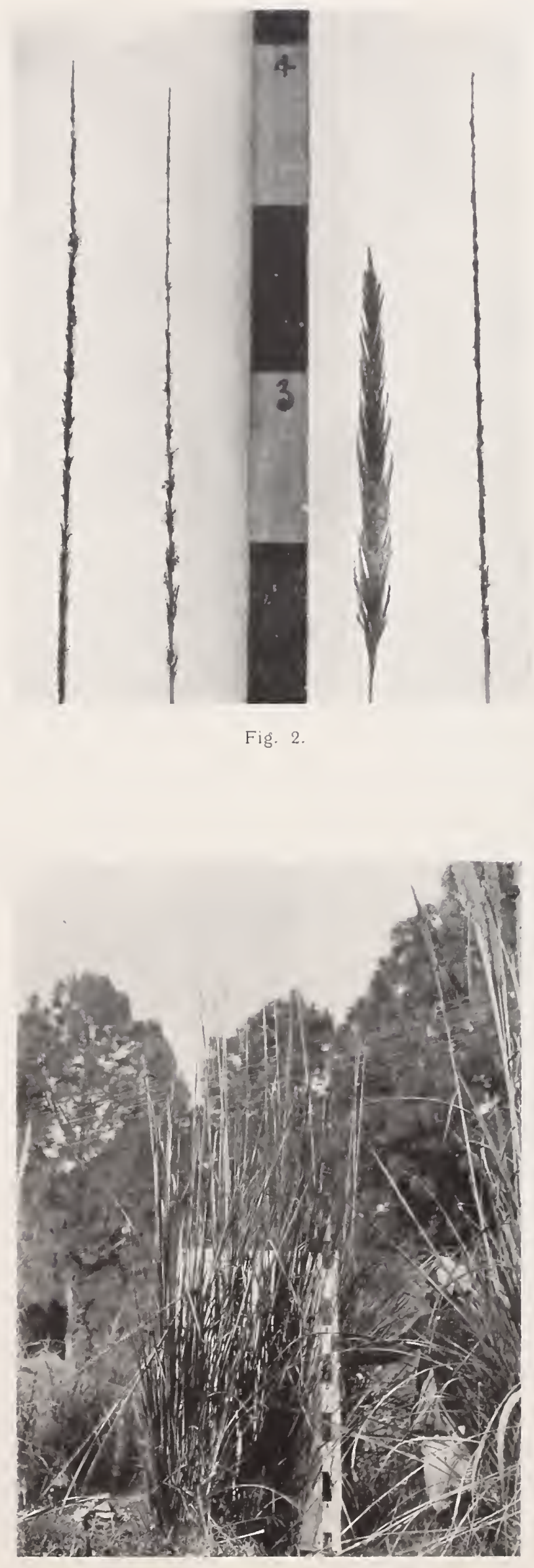

Fig. 4. 




\section{Explanation of Figures.}

\section{Plate XXIV.}

Figs. 1-4. Culms of Saccharum Narenga which have become fistular owing to an insect- or fungus-attack at the leaf-insertion. In Figs. 1 and 2 the base of the leaf-sheath has not been removed, in Fig. 3 the base of the leaf-sheath has been removed from its insertion showing an axillary bud and the culm-node immediately above it. In Fig. 4 also the base of the leaf-sheath has been removed from its insertion and a section cut through the centre of the culm showing the hollows caused by the attack.

Fig. 5. Leaf of Saccharum Narenga.

"6. Top of leaf-sheath and base of lamina showing the section of the lamina and the ligule of Saccharum Narenga.

Figs. 7-8. The uppermost leaf of the flowering culm of Saccharum Narenga.

Fig. 9. Portion of culm of Saccharum Narenga showing the smooth culm and the hairy leaf-sheath and leaf-insertion.

All figures $\times \frac{3}{1}$. 


$$
\text { H: }
$$





\section{Explanation of Figures.}

\section{Plate XXV.}

Figs. I-IV. Glumes I, II, III and IV of pedicelled spikelet of Saccharum Narenga $\times 6$.

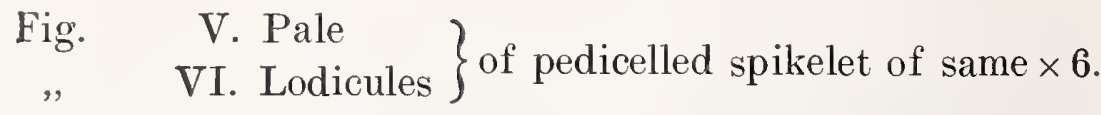

Figs. 1-4. Glumes 1, 2,3 and 4 of sessile spikelet of same $\times 6$.

$\left.\begin{array}{ll}\text { Fig. } & \text { 5. Pale } \\ \text {, } & \text { 6. Lodicules }\end{array}\right\}$ of sessile spikelet of same $\times 6$.

$\left.\begin{array}{l}\text { 7. Stamen } \\ \text { 8. Ovary and Stigmas }\end{array}\right\}$ of same $\times 6$.

$"$

,

9. Sessile and pedicelled spikelet of same species with joint of axis $\times 6$.

, 1.0. Pedicelled spikelet of same $\times 6$.

„ 11. Saccharum fuscum Roxb., copied from Roxburgh's drawings, Vol. II, No. 73. Note the distinct pedicels of both spikelets of each pair.

12. Portion of rhizome of Saccharum Narenga showing the aerial culms. developing from the terminal bud of the rhizome and as axillary shoots from the basal nodes of older culms. The basal leaves have been removed to show the internodes $\times 1 / 1$.

, 13. One-year culm of Saccharum Narenga with the basal leaves removed to show the short basal internodes. There are 13 internodes of which the upper three, (a) - (a), are still soft and immature, (b), (b) scars of roots which have been cut off, (c) an axillary bud, (d) scar from which an axillary bud has been removed $\times 1 / 1$.

" 14. Another one-year culm of the same species. There are 12 short basal internodes of which the upper two, (a), (a), are still soft and immature. (b), (b) root scars, (c), (c) axillary buds $\times 1 / 1$.

15. Portion of rhizome of Saccharum Narenga (a), (a), young buds from which the scale-like outer leaves have been removed, (b) axillary bud from which the basal 4 scale-leaves have been removed showing the next two leaves with small lamina.

(c) immature one-year culm with 12 short basal internodes the upper two of which are still soft and immature.

id) mature flowering culm with 8 short basal internodes $\times 1 / 1$. 

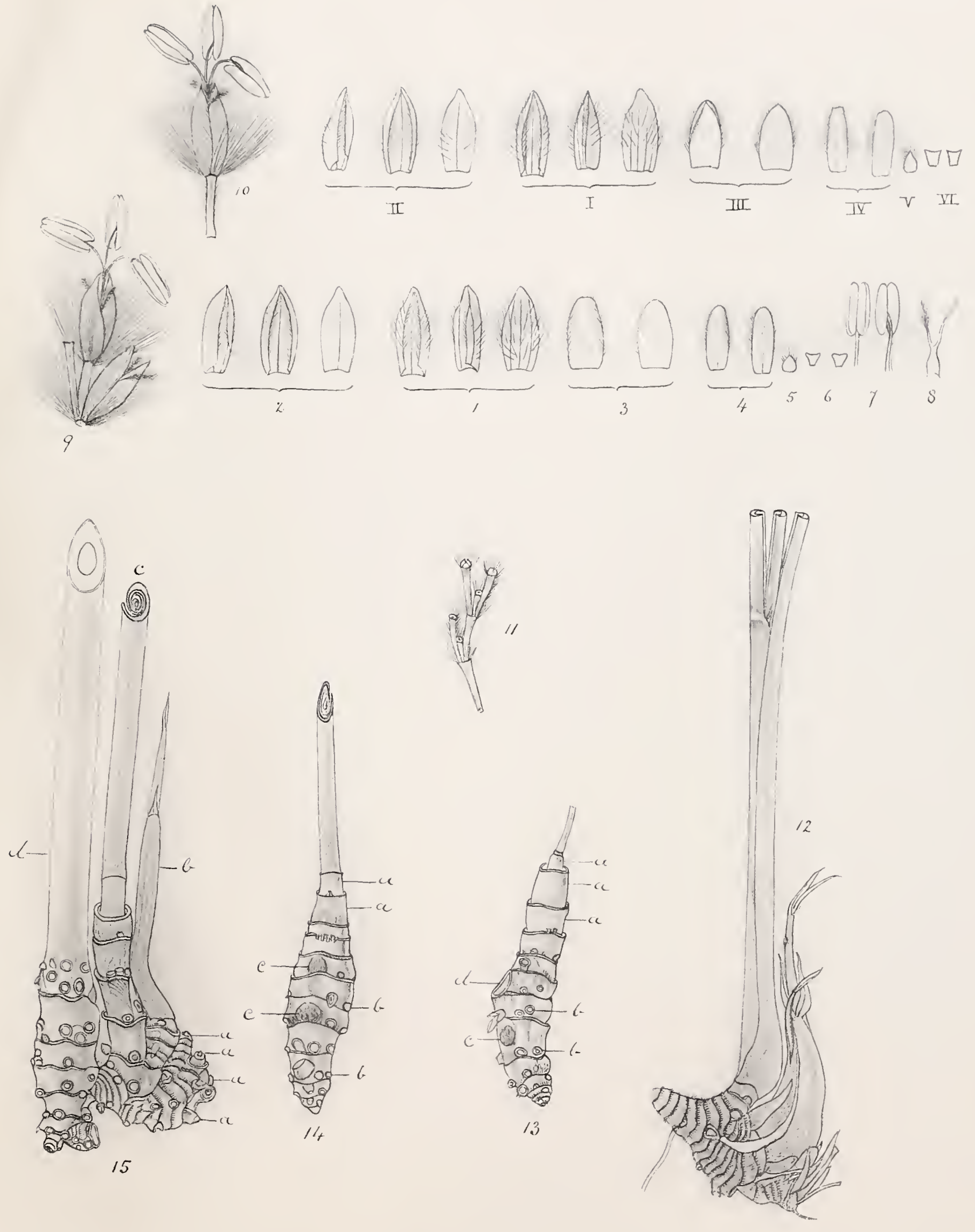




\section{Explanation of Figures.}

\section{Plate XXVI.}

Fig. 1. Flowering panicle of Erianthus Ravennce, collected October 1909.

„2. Two fruiting panicles of Erianthus Ravennce, collected November 1909.

"3. Group of the same species growing in Dehra Dun Experimental Garden. Photograph taken October 1909.

, 4. Pair of spikelets of same with joint of axis

1,1 , Glume 1 of sessile spikelet of same

2,2

3,3

, 3,4,

4, 4, , 4 ",

$\mathrm{P}$ Pale

S Stamens

O Ovary showing stigmas

L Lodicules

all $\times 4 \frac{1}{2}$. 

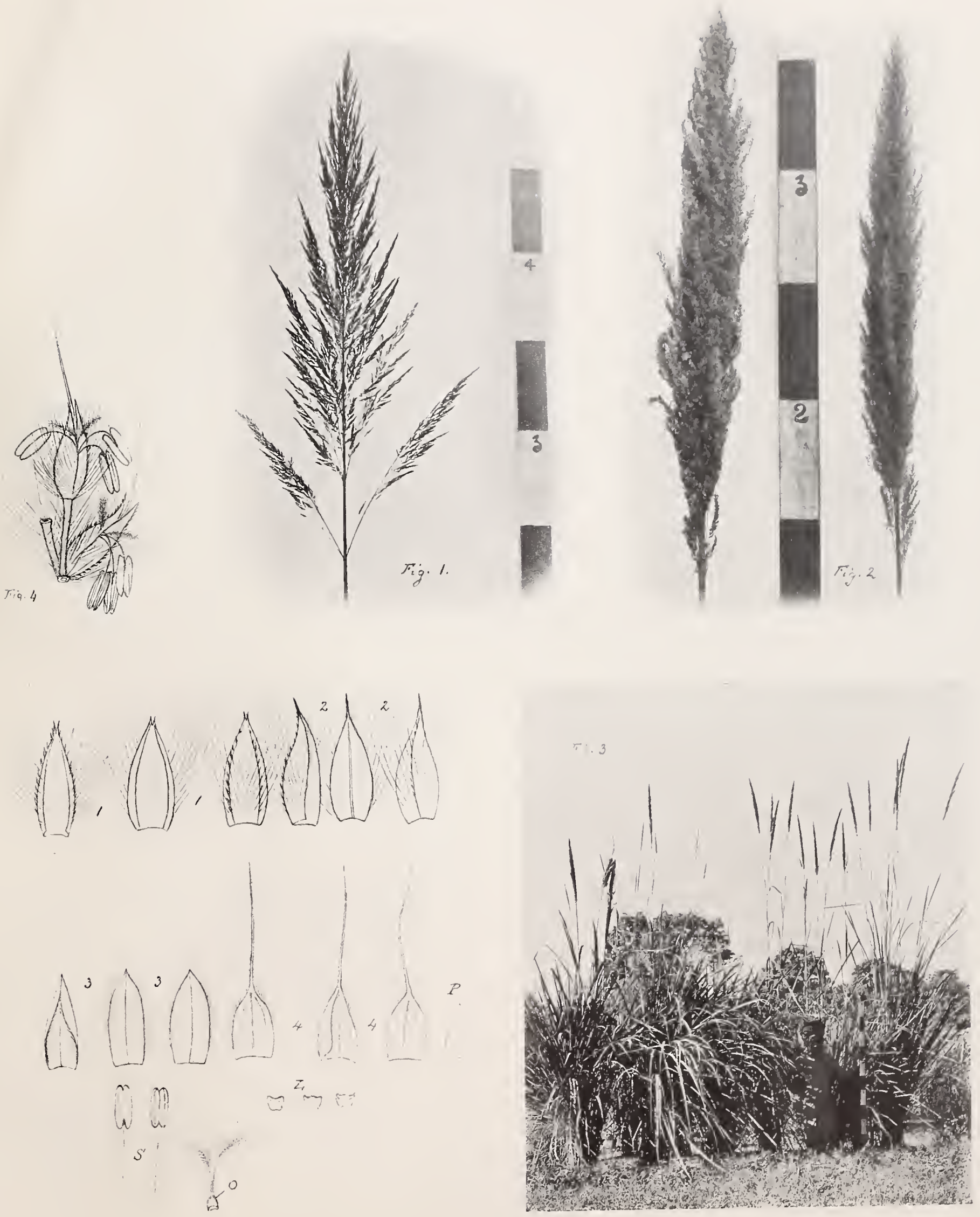




\section{Explanation of Figures.}

\section{Plate XXVII.}

Fig. 1. Culm of Erianthus Ravenno, (a), leaf-insertion, (b), culm-node, (c), axillary bud, (d), base of hairy leaf-sheath.

„2. Lower leaf of same.

, 3. Uppermost leaf of flowering culm of same.

Figs. 4-5. Base of lamina and top of leaf-sheath of same showing the concave midrib and ligule.

All figures $\times \frac{3}{4}$. 




\section{Explanation of Figures.}

Plate XXVIII.

Fig. 1. Flowering panicle of savannah form of Imperata arundinacea.

"2. Fruiting panicle of same.

3. 3. Depauperate culm of Imperata arundinacea collected from an area where the grass is annually cut at the close of the rains and which is then frequently grazed over, (a), (a), the bearded leaf-insertions, (b), (b), the long villi at base of lamina.

". 4. Ligule of plant shown in Fig. 3.

Figs. $1-4$ all $\times \frac{3}{4}$.

"5. Pair of spikelets of savannah form of Imperata arundinacea $\times 2 \frac{1}{4}$.

"6. Spikelet of same showing callus hairs $\times 3$.

, 7. Callus hairs of same $\times 3$.

I, I, Glume I of same

II, II, , II ,

III, III, , III ,

IV, IV, , IV , $\} \times 3$

$\mathrm{P}, \mathrm{P}$, Pale of same

S, S, Stamens ,

O, Ovary, 


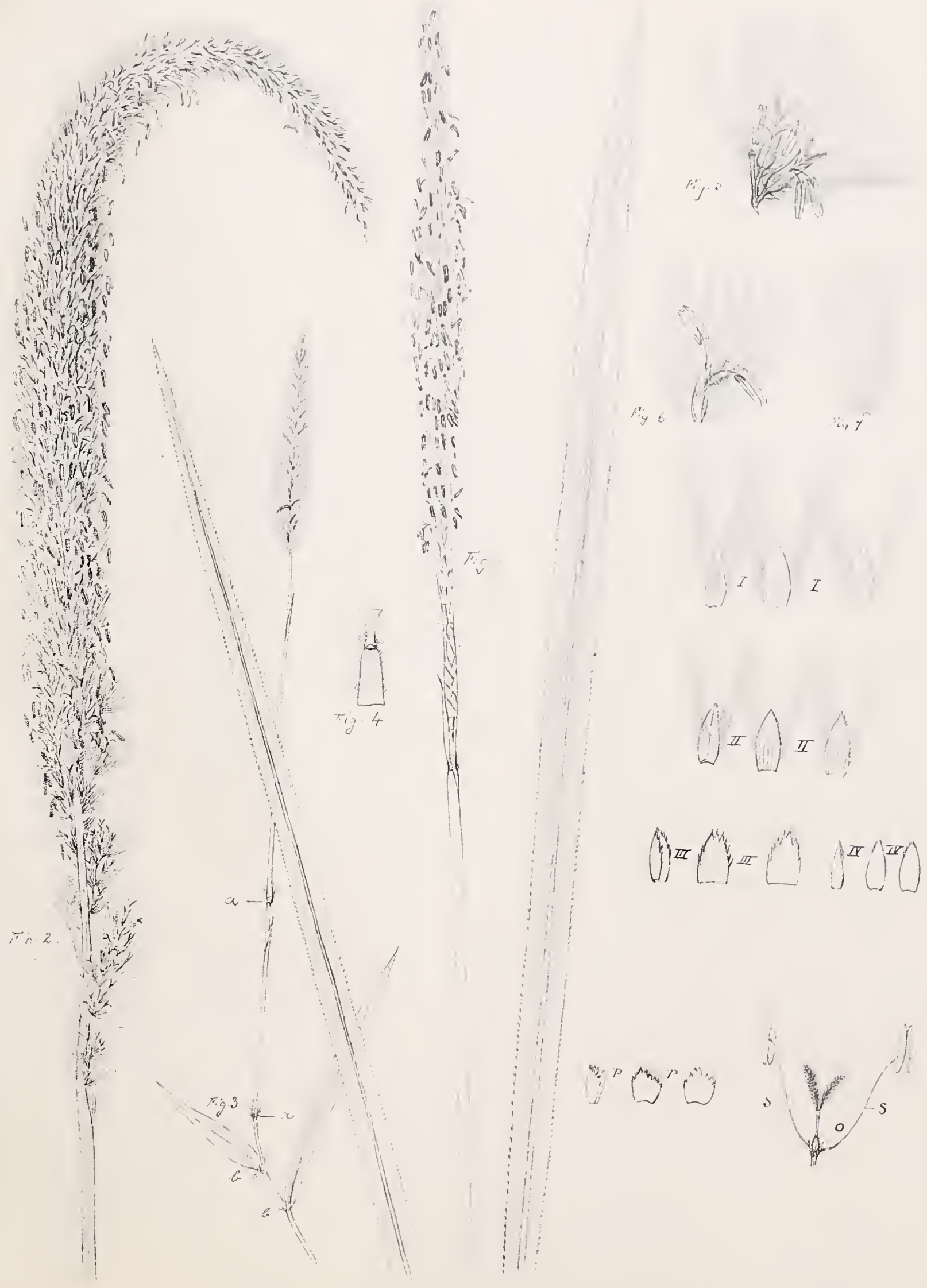





\section{Explanation of Figures.}

Plate XXIX.

Fig. 1. Leaf of savannah form of Imperata arundinacea.

"2. Base of lamina and apex of sheath of same showing ligule.

"3. (a) Stolon of same covered with membranous sheaths. (b) young aerial culm developing from terminal bud of stolon (a). (c), (c), stolon branches developed from the nodes of stolon (a).

"4. Shows the same but with the sheaths removed to show the internodes. Lettering as in Fig. 3.

"5. Base of mature flowering-culm of same showing 14 short internodes at the base (a)-(a). S, S, stolons.

"6. Base of mature flowering-culm of same showing 11 short internodes at the base (a) - (a) ; S, S, stolons.

"7. Culms of same showing transition from glabrous to densely bearded leafinsertions.

All figures $\times \frac{3}{4}$. 
PLATE $X X I X$.

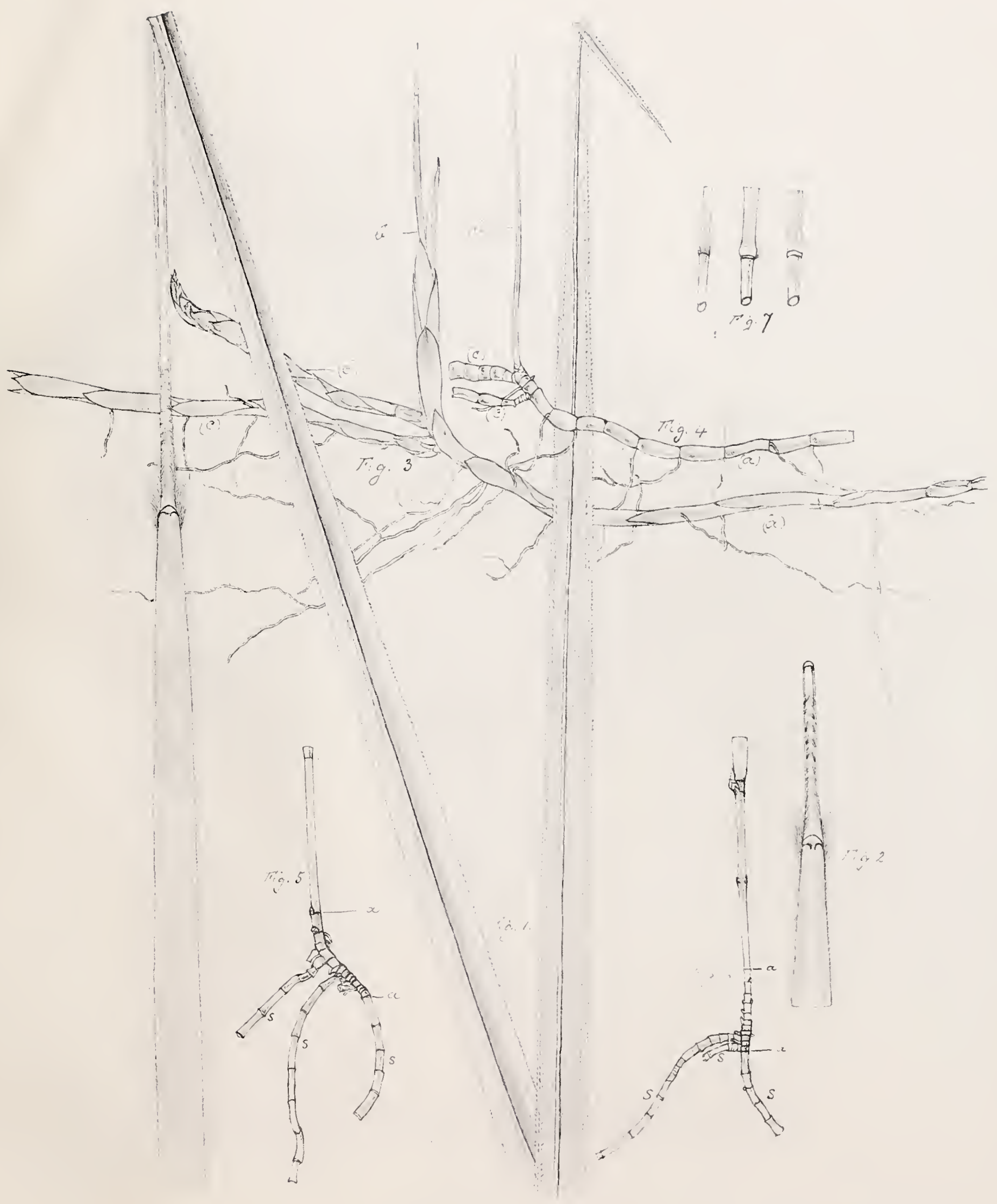






\section{Explanation of Figures.}

\section{Plate XXX.}

Fig. 1. Three plants of Imperata arundinacea growing in Dehra Dun Experimental Garden. Note the young leafy culms in the foreground springing from the wide-spreading subterranean stolons.

Photograph taken October 1909.

,2. Another group of the same in Dehra Dun Experimental Garden. The culm on the right which originated from a subterranean stolon in May 1909 has produced a flowering panicle.

Photograph taken December 1909.

"3. Panicles of the same. The three central panicles were collected from a grass lawn where the plants had been dwarfed by grass-cutting. The outermost panicle on the right and the two outermost panicles on the left belong to the swamp-form and were collected in a marsh. The remaining three panicles belong to the ordinary savannah form of the species. 


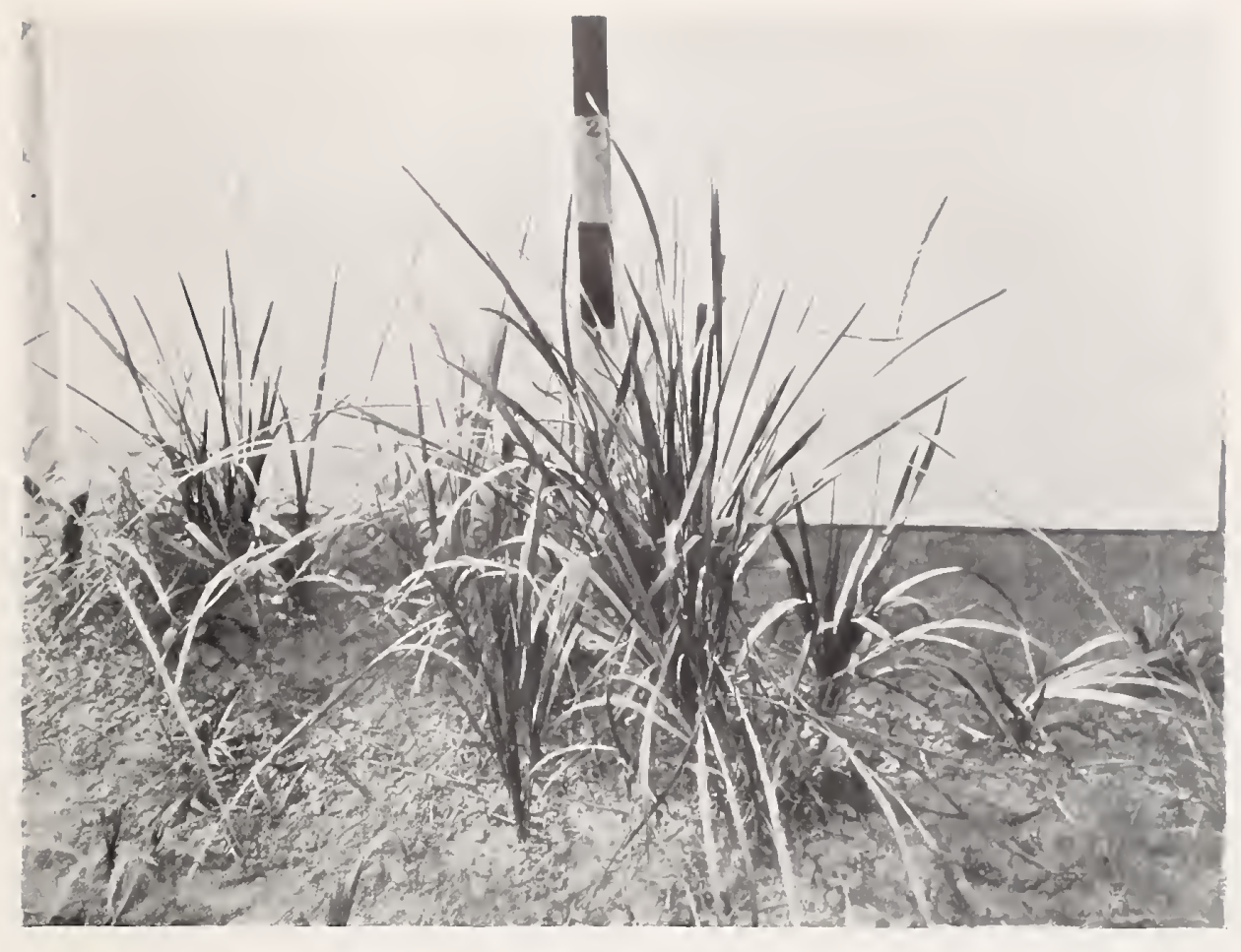

Fig. 2.

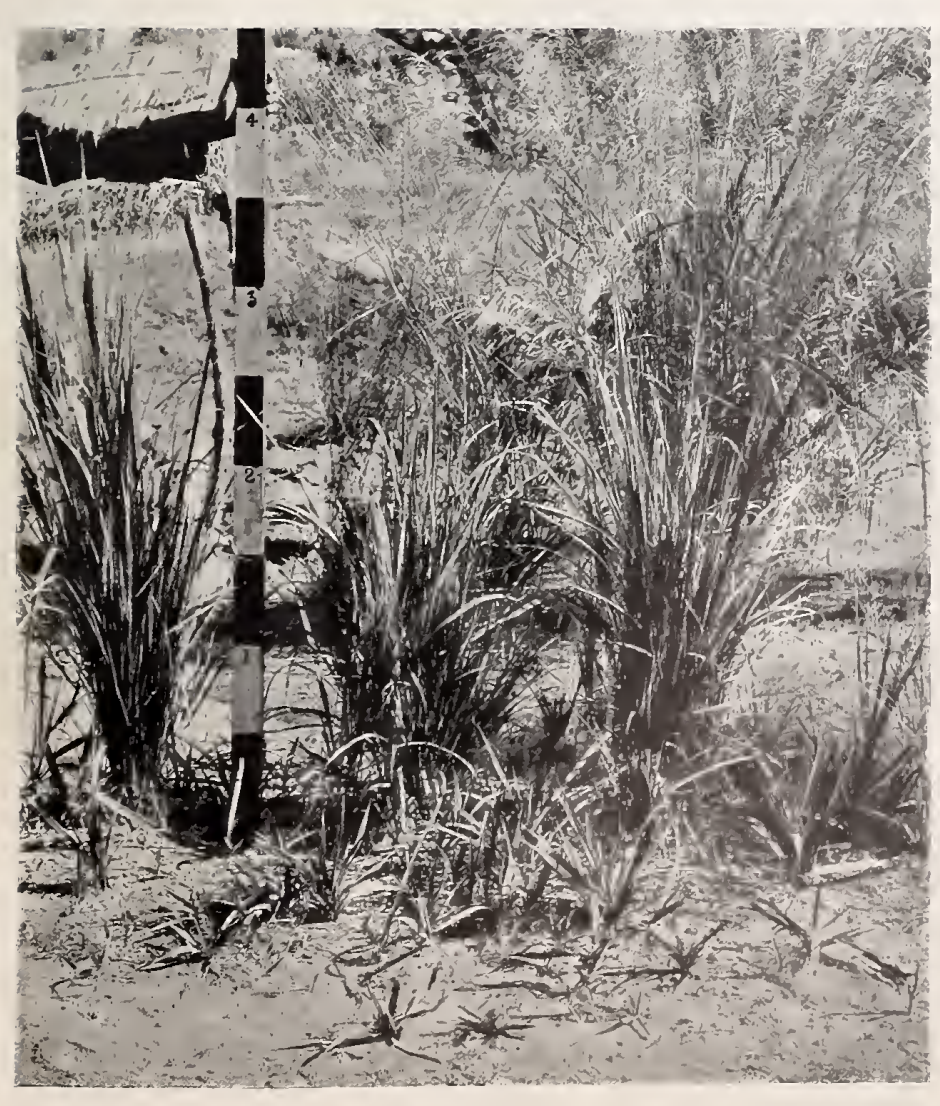

Fig. 1

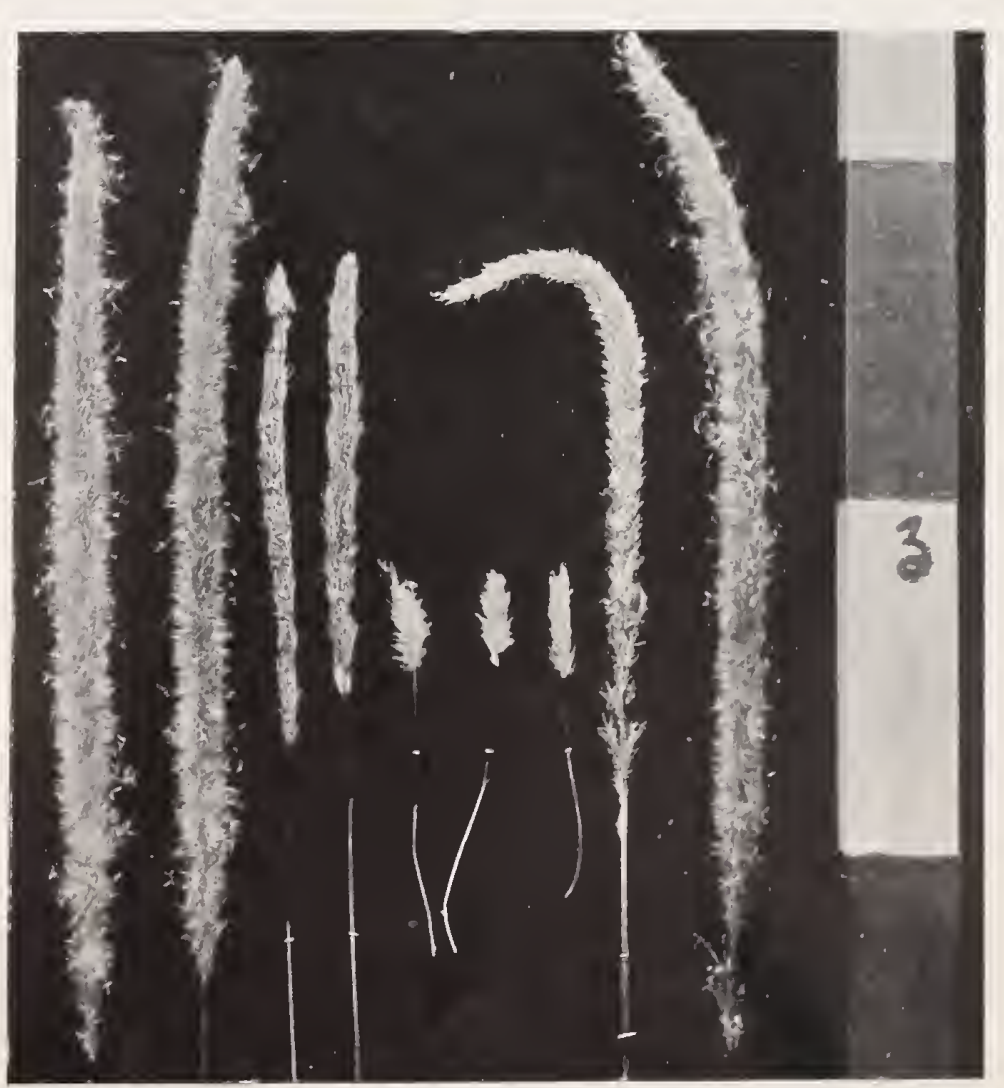

Fig. 3. 



\section{Explanation of Figures.}

Plate XXXI.

Fig. 1. Flowering panicle of Triraphis madagascariensis.

Photograph taken September 1909.

"2. Fruiting panicles of Triraphis madagascariensis.

Photograph taken November 1909. 

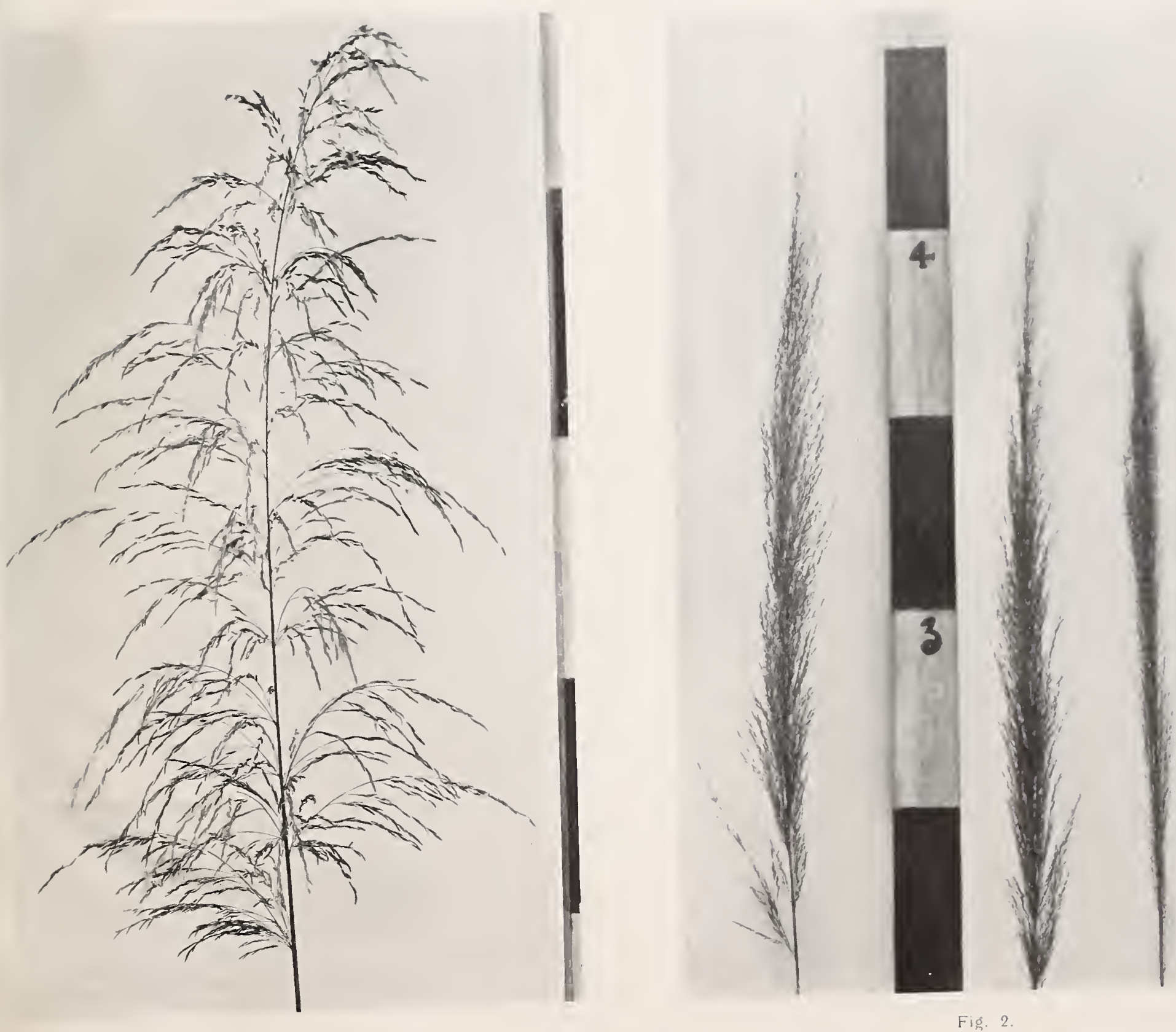

Fig. 1. 




\section{Explanation of Figures.}

\section{Plate XXXII.}

Fig. 1. Triraphis madagascariensis growing in Dehra Dun Experimental Garden. Photograph taken September 1909.

"2. Spikelets of same $\times 3$.

"3. One spikelet of same $\times 6$ approx. showing the rachilla jointed and bearded between the flowering glumes.

"4. One flowering glume of same embracing the pale

I, I, Glume I of same

II, II, , II ",

III, III, Flowering glume of same
$\mathrm{P}$ Pale of same
L Lodicules ",
S Anthers
O Ovary

all $\times 6$. 


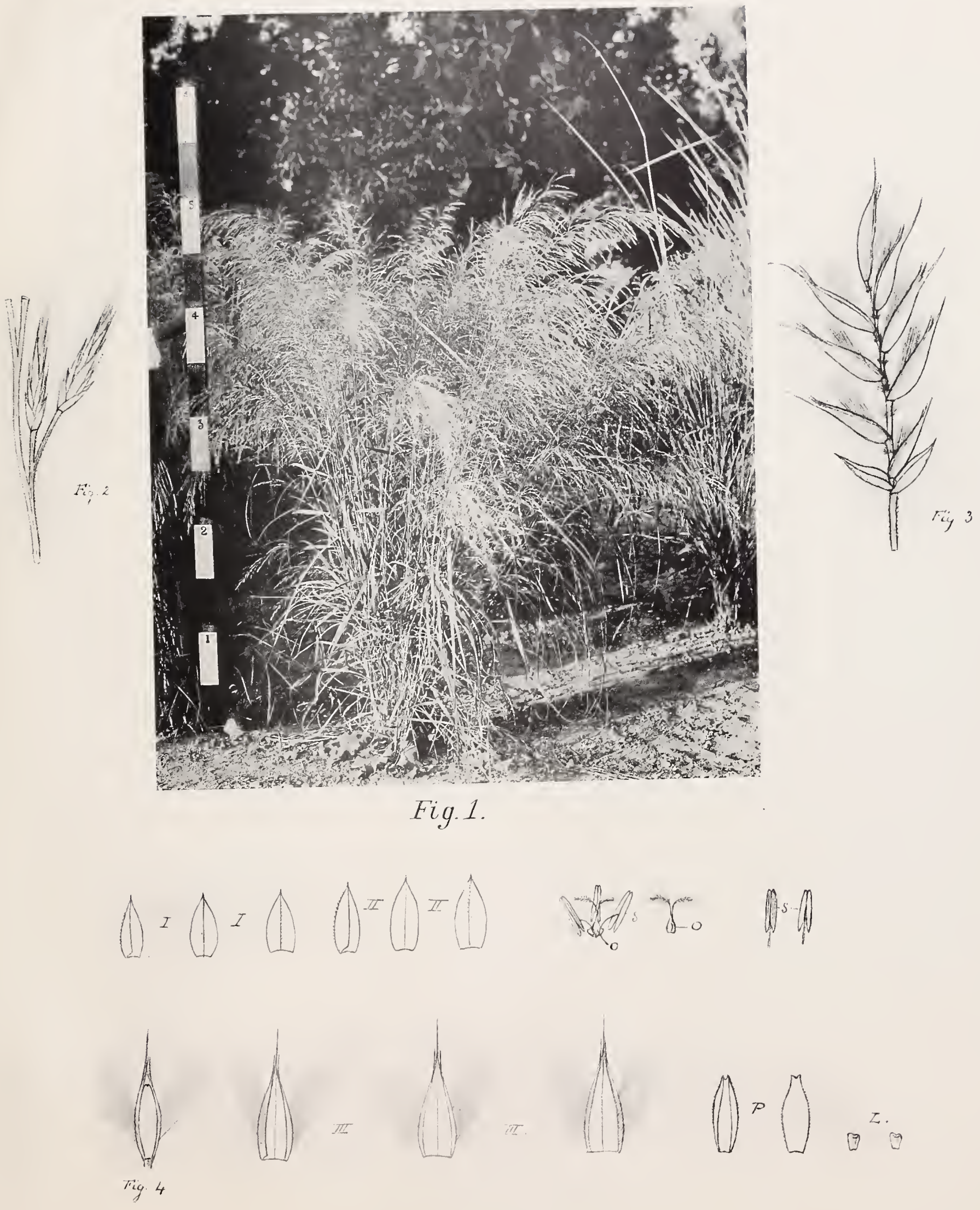






\section{Explanation of Figures.}

\section{Plate XXXIII.}

Fig. 1. Culm of Triraphis madagascariensis.

"2. Ditto showing leaves.

"3. Base of lamina and apex of leaf-sheath of same showing ligule.

"4. Base of mature flowering culm of same showing the short internodes and numerous large buds at base.

"5. The same with the roots cut away to show the short basal internodes more clearly. In this case there are 13 short basal internodes.

All figures $\times \frac{3}{4}$. 

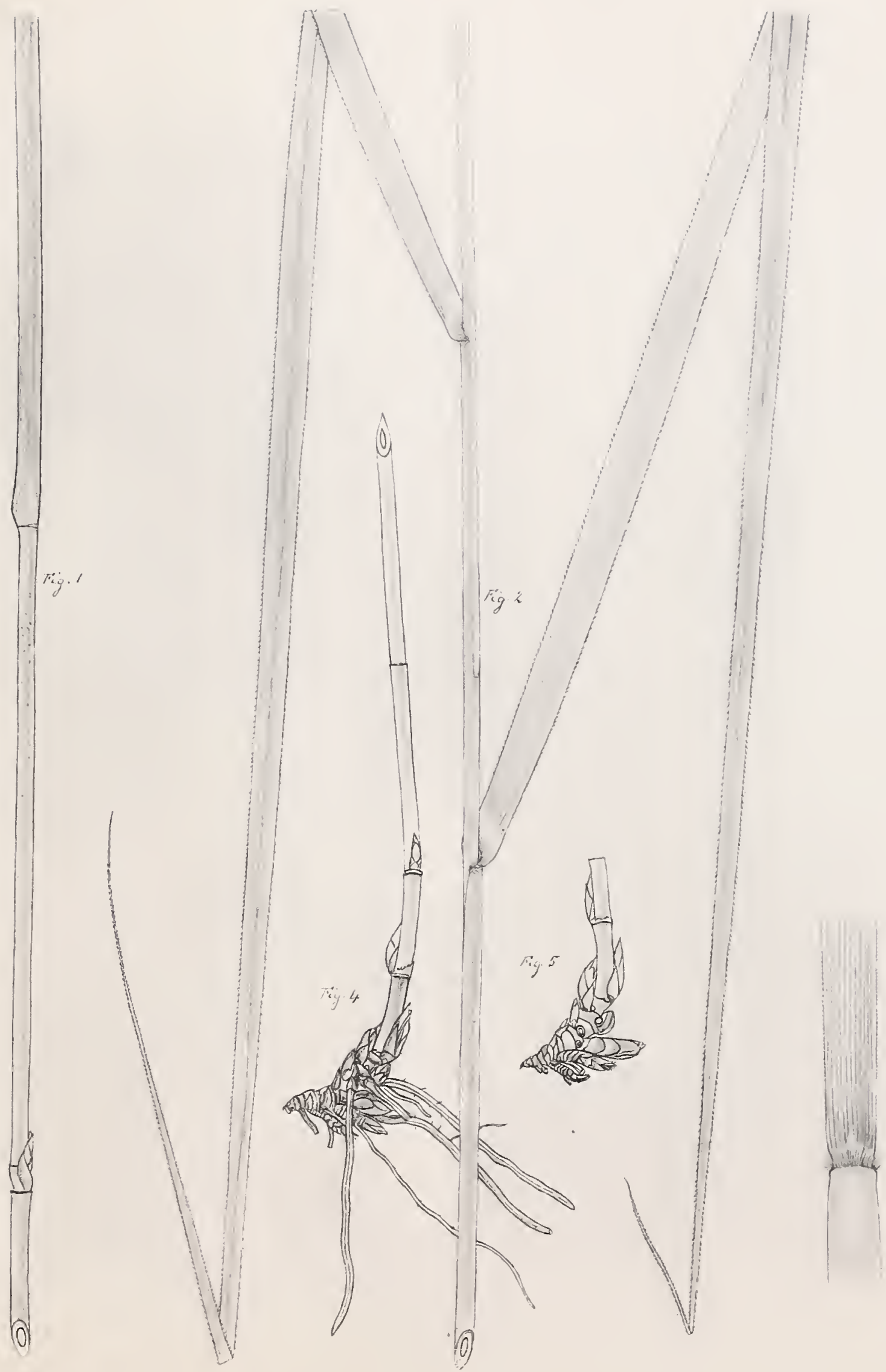



\section{Explanation of Figures.}

\section{Plate XXXIV.}

A ristida cyanantha in gravelly stream bed near. Jhajra.

Photograph taken 21st October 1909. 


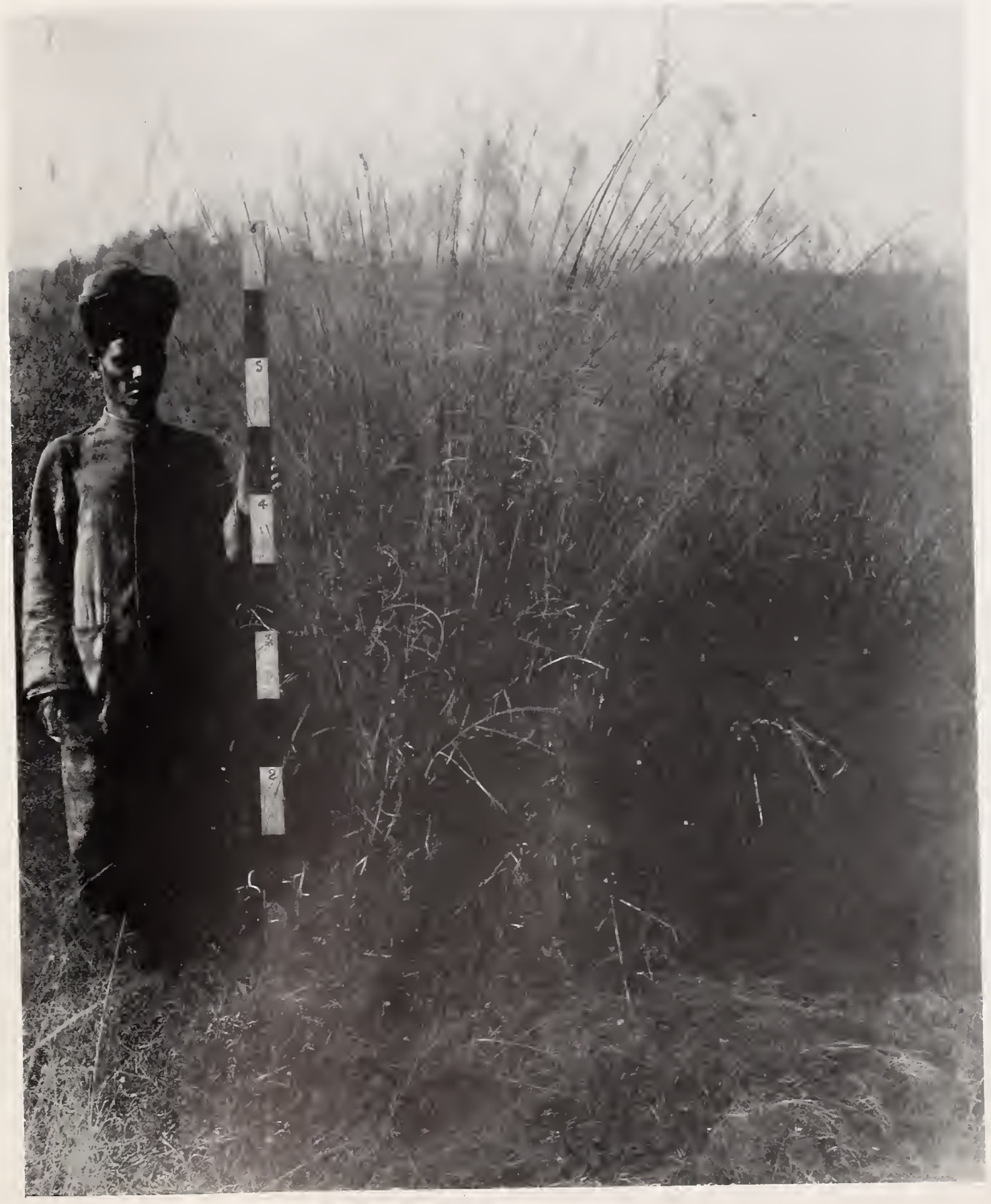



- 


\section{Explanation of Figures.}

\section{Plate XXXV.}

Fig. 1. Flowering panicle of A ristida cyanantha $\times \frac{3}{4}$.

"2. Flowering spikelet of same $\times 1 / 1$. Note the erect adpressed awns.

, 3. Fruiting spikelet of same $\times 1 \frac{1}{4}$. Note the 3 spreading awns.

Figs. 4 -5. Spikelets of same attacked by Ustilago aristida-cyananthe. Note the remarkable pod-like structures $\times \frac{3}{4}$. 


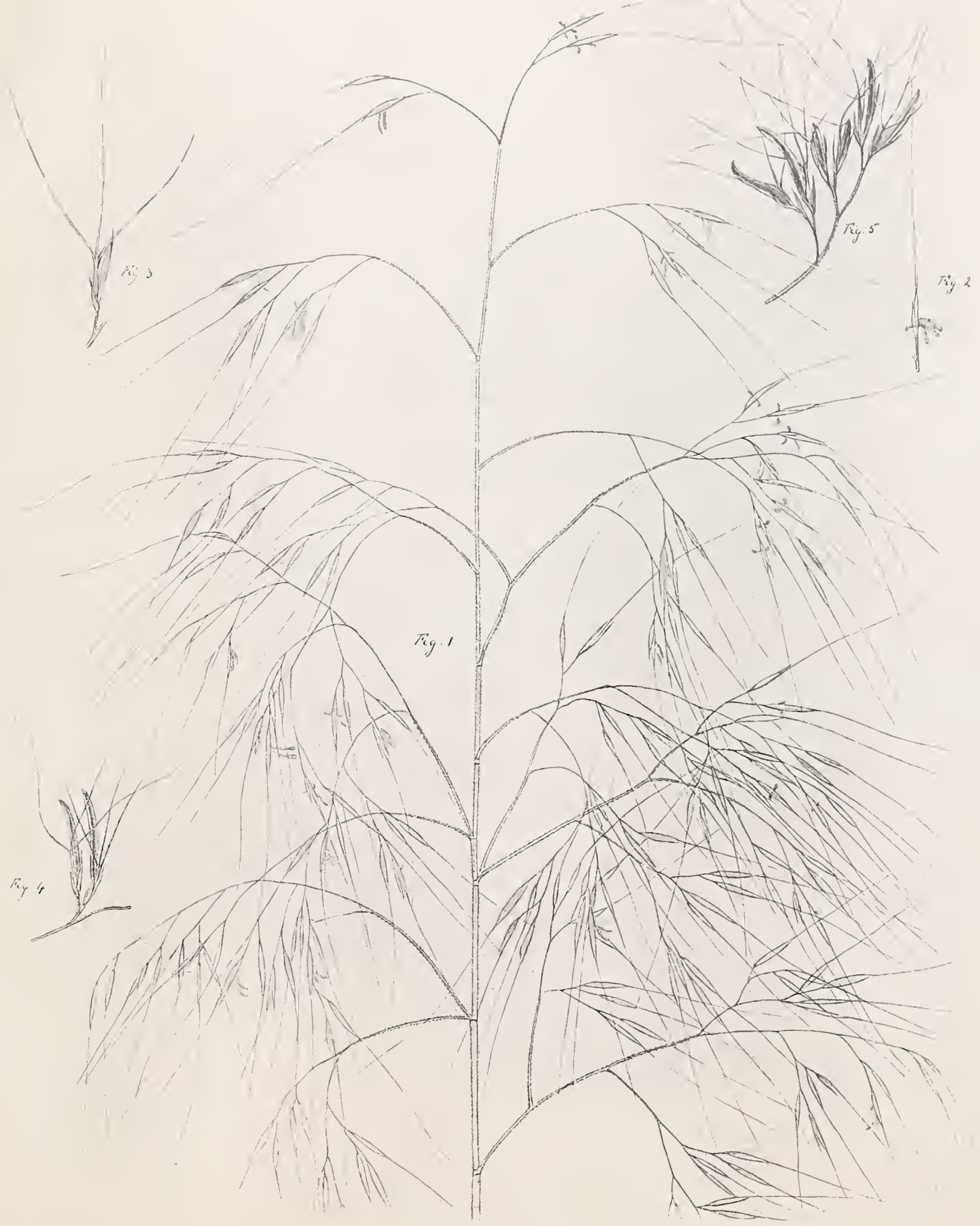




\section{Explanation of Figures.}

\section{Plate XXXVI.}

Fig. 1. Culm of Aristida cyanantha (a) leaf-sheath from which the lamina has been shed, (b) leaf-insertion, (c) culm-node, (d) axillary shoot with scaly leaves at base $\times \frac{3}{4}$.

"2. Lamina of same showing ligule at (a) $\times \frac{3}{4}$.

"3. (a) Mature flowering culm of same which has developed as an axillary shoot from the basal node of an older culm (b). (c) is another axillary shoot springing from (b) which at present is merely a large bud. There are 9 short internodes at the base of (b) and 6 short internodes at the base of (a) $\times \frac{3}{4}$.

, 4. Spikelet of same $\times 1 / 1$

I, I, Glume I of same

II, II, , II ,"

III, III, , III ,

P Pale ,

$\mathrm{L}$ Lodicules ".

S Anther

O Ovary

all $\times 3$. 

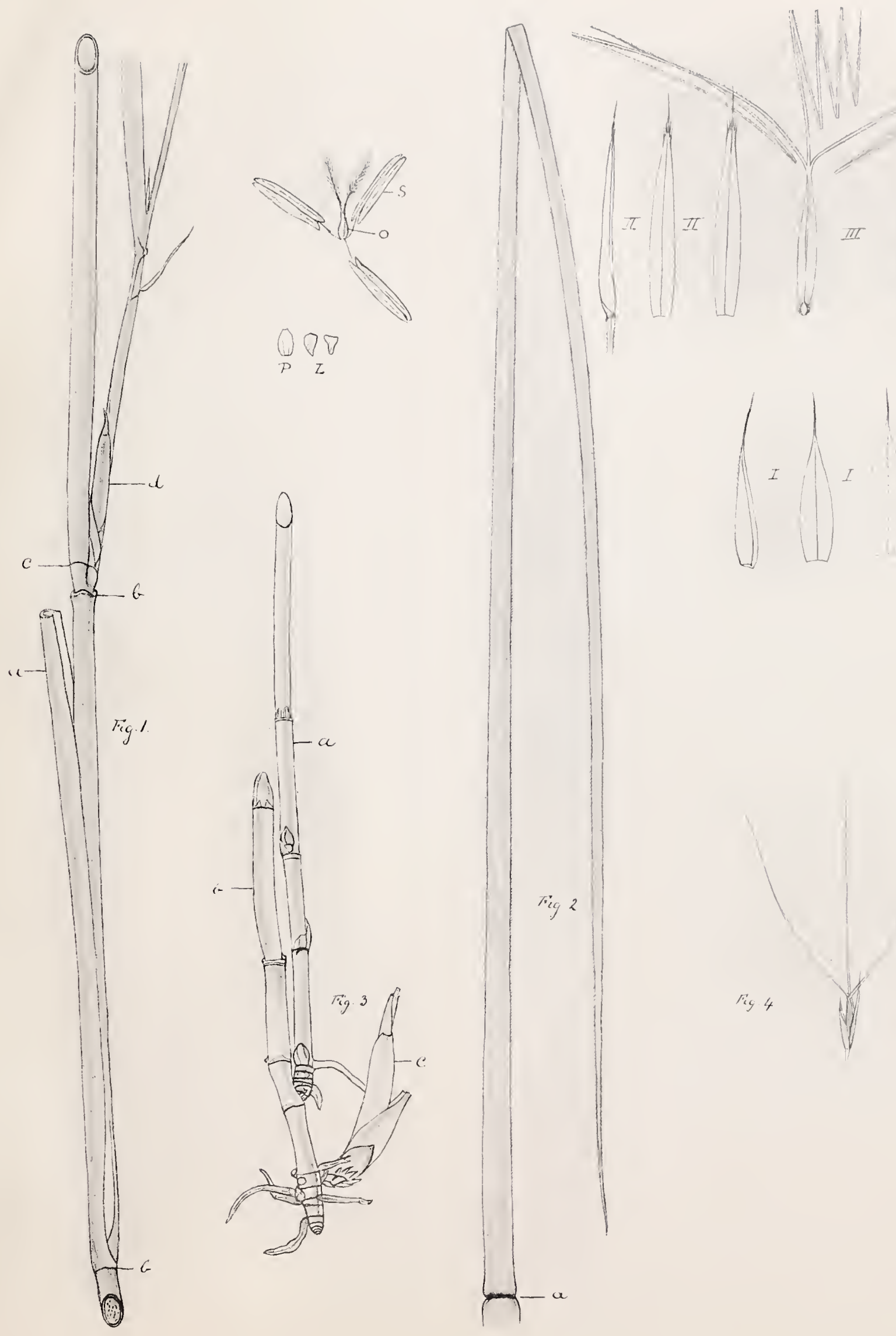

• 


\section{Explanation of Figures.}

\section{Plate XXXVII.}

Fig. 1. Andropogon monticola var. robustus growing in Dehra Dun Experimental Garden.

Photograph taken October 1909. This is a robust plant which shows little to no hair on the basal $\frac{2}{3}$ rds of Glume II of sessile spikelet and which approaches var. Trinii very closely.

"2. Another less robust plant of the same variety also growing in Dehra Dun Experimental Garden.

Photograph taken September 1909. This plant showed the middle third of Glume II of sessile spikelet pectinately white-ciliate and was taken from a dry sandy soil in a locality which is annually fired. 


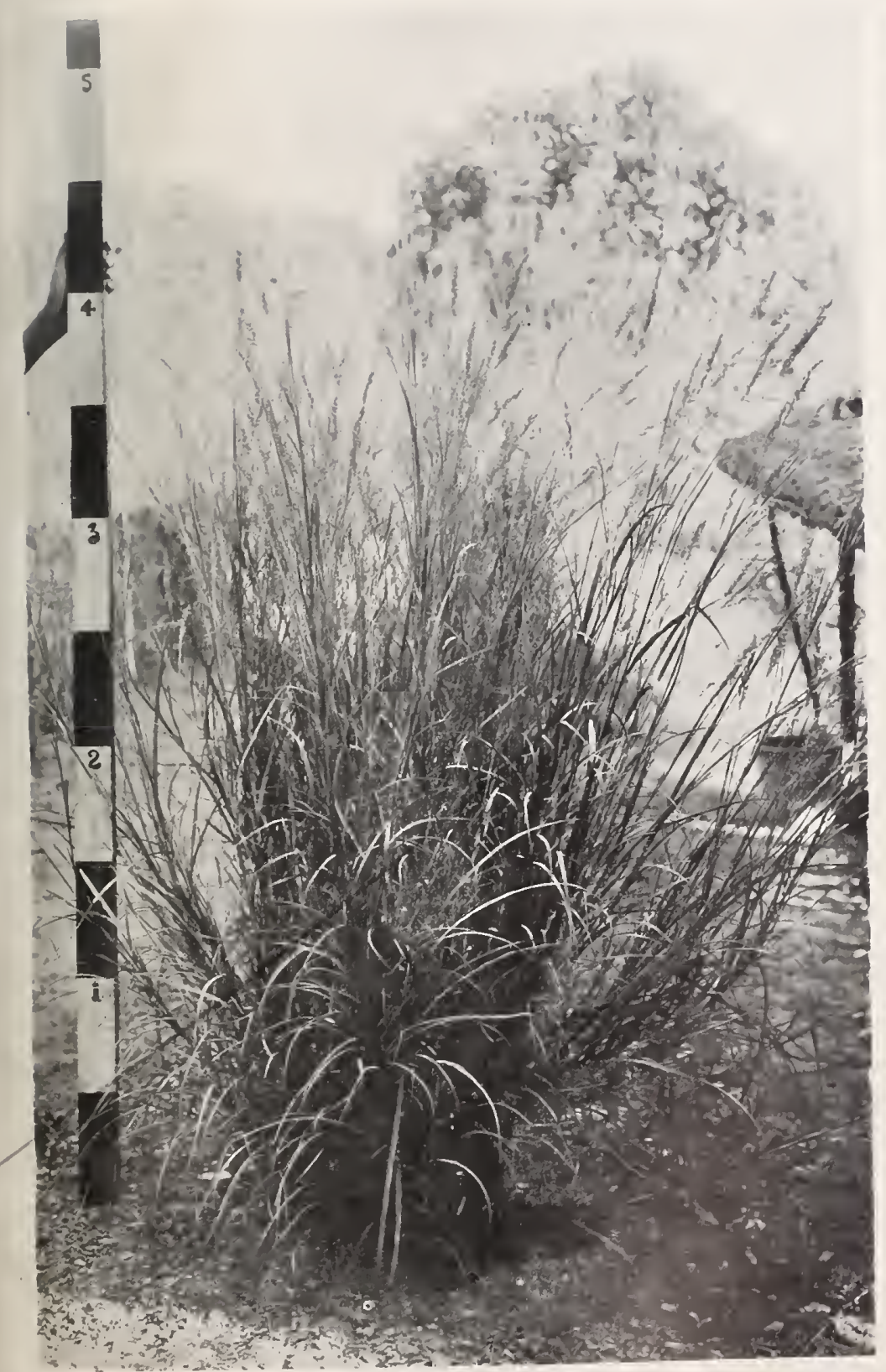

Fig. 1

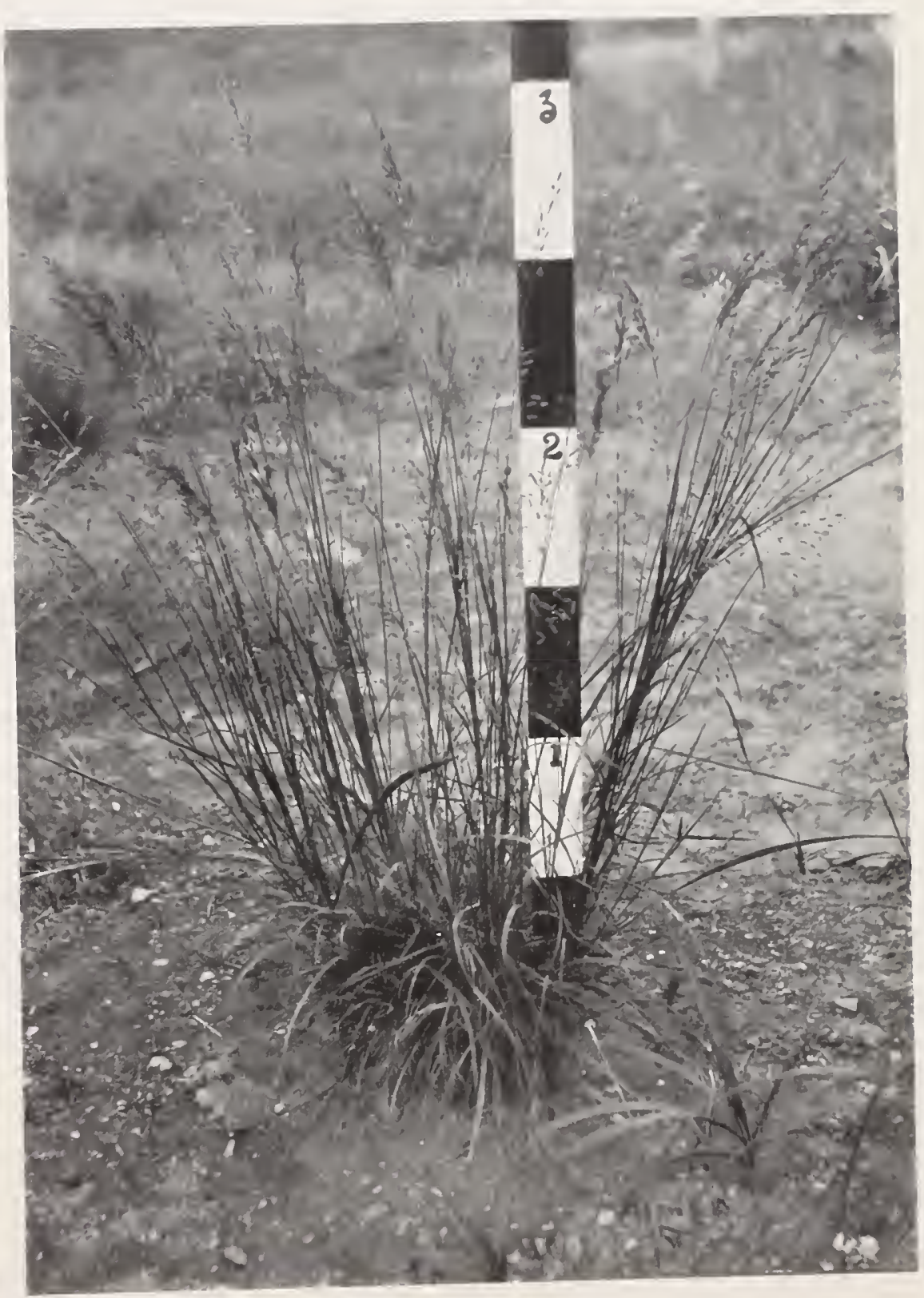

Fig. 2 




\section{Explanation of Figures.}

\section{Plate XXXVIII.}

Fig. 1. Flowering panicle of Andropogon monticola. Note the spreading branches $\times \frac{3}{4}$.

, 2. Fruiting panicle of same. Note the erect branches $\times \frac{3}{4}$.

"3. Panicle of same after the fall of the spikelets showing the bearded tips of the branches $\times \frac{3}{4}$

Figs. $4 \& 5$. A single cluster of spikelets of same showing the central $\xi$ and two lateral o'spikelets $\times 2 \frac{1}{4}$.

Fig. 6. Base of lamina and top of sheath of same showing the ligule $\times \mathbf{1} / \mathbf{1}$.

"7. Base of culm of same showing 13 short basal internodes, from which numerous buds are developing which will produce next year's culms $\times \frac{3}{4}$.

" 8. Culm of same showing the leaves and flowering axillary branches $\times \frac{3}{4}$. 


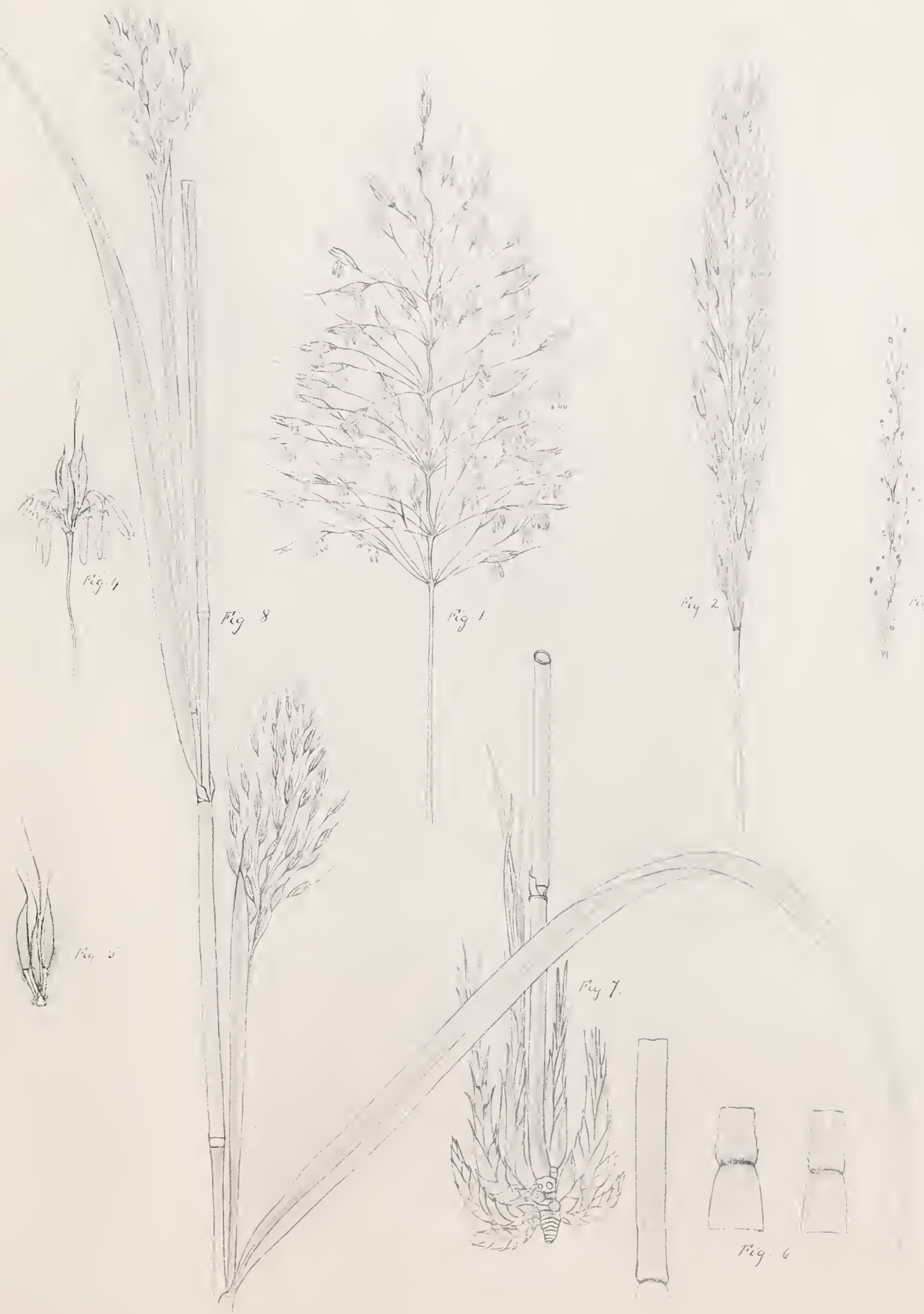





\section{Explanation of Figures.}

\section{Plate XXXIX.}

Fig. 1. Culm of Andropogon monticola var. robustus showing the fan-like arrangement of the branches.

, 2. Sessile $\hat{t}$ spikelet of same

", 3. Pedicelled o spikelet of same

I, I, Glume $I$ of sessile spikelet of same

II, II, ", II , " , ,

III, III, " $\quad$ III " , " , "

IV, IV, ", IV , , , , ,

$1,1, \quad, \quad 1$ pedicelled ,, ,

$2,2, \quad, \quad 2 \quad, \quad$, "

3,3 , " $3 \quad$ " , " ,

$4,4, \quad, \quad 4 \quad, \quad$, ,

$\mathrm{S}$ Anthers

O Ovary

L Lodicules

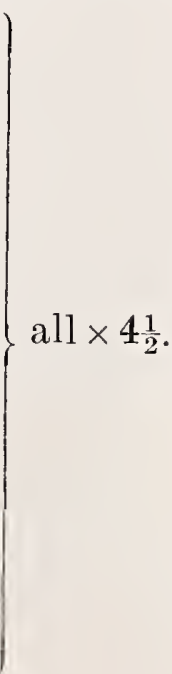



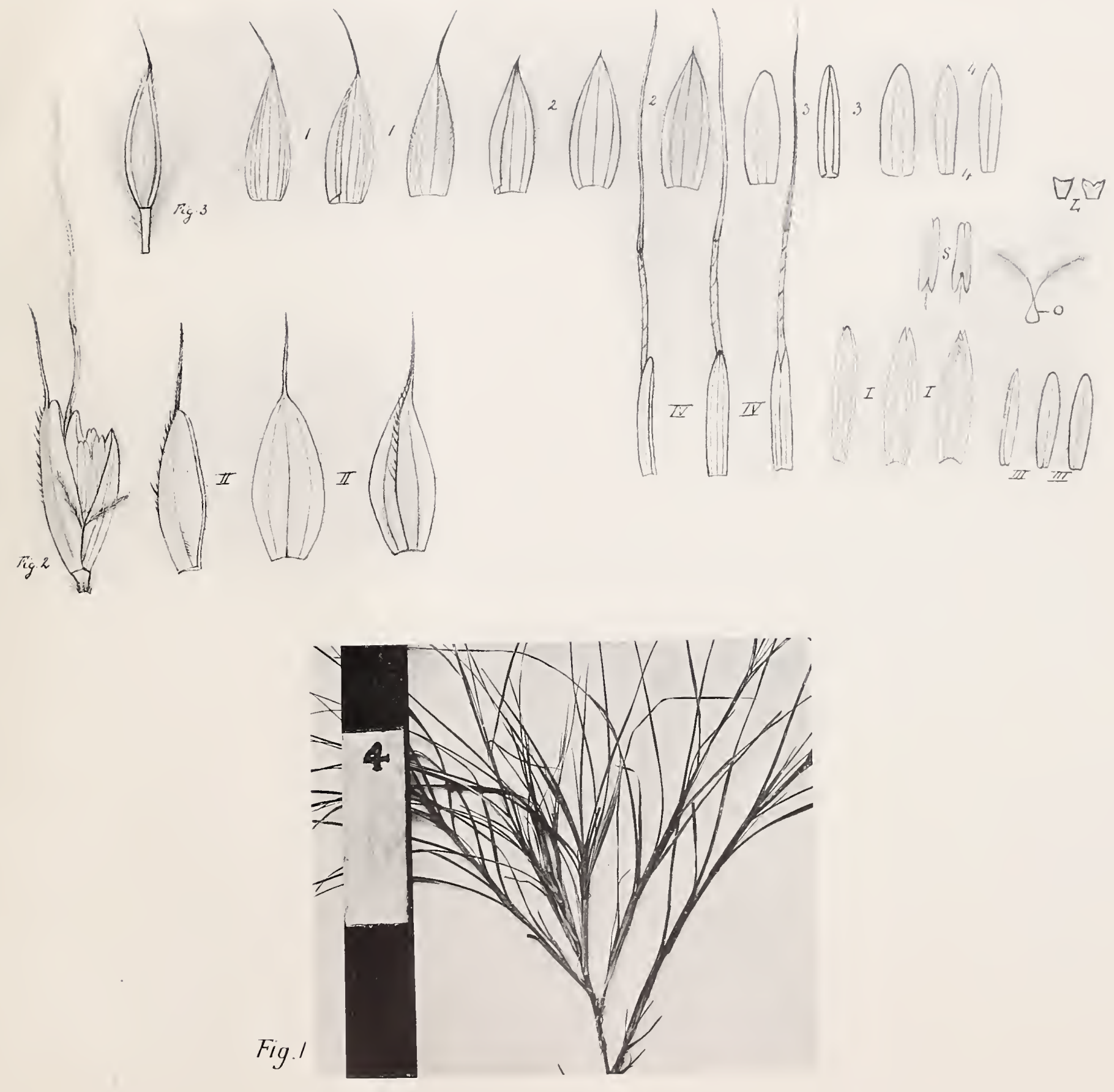



\section{Explanation of Figures.}

\section{Plate XL.}

Gola Tappar, a grassland, which is believed to have originated from a clearing being made in Sal Forest for purposes of cultivation. Note the dense wall of Sal Forest surrounding the grassland; the Himalayas are seen in the distance.

This grassland is annually fired, but is closed to grazing. The Sal-locality-indicating grass Saccharum Narenga is common in this area, but note the inferior dimensions attained as compared with those shown in Plates XI and XII. In parts of this area, also, the xerophilous Andropogon contortus is dominant. These characteristics indicate a drying up of the soil, which has been probably caused partly by the surrounding forest interfering with the free circulation of air currents and thus causing intense insolation, but which has undoubtedly been accentuated by the annual fires.

Photograph taken January 1910. 


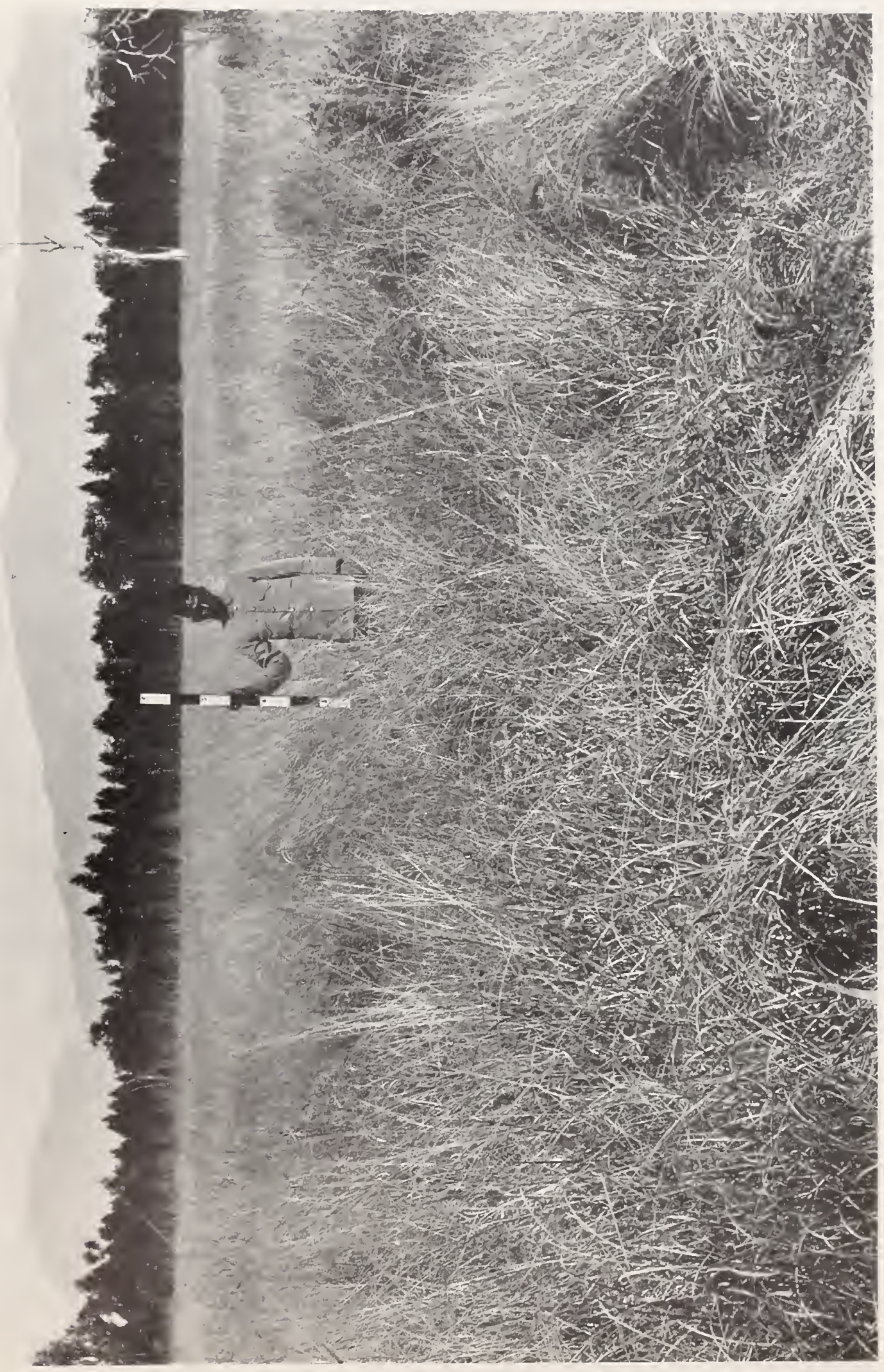




